\title{
Jurisdição Constitucional da Igualdade
}

Dissertação apresentada à Faculdade de Direito da Universidade de São Paulo como requisito para obtenção do título de mestre, sob a orientação do Professor Doutor Roger Stiefelmann Leal, na área de Direito do Estado, subárea de Direito Constitucional.

\section{Henrique CAMpos Galkowicz}

20 de janeiro de 2014 
Banca examinadora: 


\section{RESUMO}

Jurisdição constitucional da igualdade é o título deste trabalho, que se volta para o estudo do controle de constitucionalidade realizado com parâmetro no direito de igualdade. Seu objetivo principal é desenvolver uma metodologia analítica e pragmática de aplicação judicial do direito constitucional de igualdade, de modo a permitir uma compreensão jurídica da matéria.

Para cumprir seus objetivos, optou-se por uma lógica dedutiva, iniciando-se com a formatação de uma premissa conceitual e abstrata do direito de igualdade para, ao final, culminar no estudo de aspectos processuais concretos da aplicação judicial da igualdade. Ao longo da dissertação, foram investigados os elementos fundamentais da tutela judicial da igualdade, bem como as principais questões funcionais relativas ao papel dos poderes judiciário e legislativo na concretização do direito em exame.

Como resultado, foram estabelecidos critérios objetivos para a identificação do vício de inconstitucionalidade, da sua competência reparatória e das ferramentas processuais da sua tutela judicial, tudo isso em consonância com as características normativas peculiares do direito de igualdade.

\section{Palavras-chave}

Igualdade; jurisdição; constitucional; reparação; competência. 


\begin{abstract}
Judicial review of equality is the title of an essay aimed to research the judicial review based on constitutional equality law. Your main scope is to develop an analytical and pragmatic methodology about the enforcement of equality law, so that allow a legal comprehension of the subject.

To meet your goals, a deductive logical was chosen, starting with the formatting of a conceptual and abstract premise of the right to equality to, at the end, culminate in the study of specific legal aspects of the judicial enforcement of equality. Meanwhile, the fundamental elements of judicial protection of equality were investigate, well as the main issues concerning the functional role of the judicial and legislative powers in implementing the right in question.

As a result, objective criteria were established for the identification of unconstitutional standards, remedial powers, and procedural tools of their judicial protection, all in line with the peculiar characteristics of the normative right to equality.
\end{abstract}

\title{
KEY WORDS
}

Equality; law; judicial; review; remedial; power. 
Delimitação do Tema

Justificativa 8

Metodologia

Itinerário 15

I) Igualdade e Constituição

1.1. Considerações Gerais

1.2. Propriedades Normativas ___ 20

1.2.1. Estrutura Normativa _u 20

1.2.2. Natureza Normativa __ 24

1.3. Dimensões ___ 27

1.3.1. Igualdade Fática X Normativa ___ 27

1.3.2. Igualdade Formal X Material___ 29

1.3.3. Igualdade Paritária X Proporcional ___ 33

1.4. Conceito de Igualdade 38

1.5. Igualdade na Constituição de $\mathbf{1 9 8 8} \_\mathbf{4 0}$

1.5.1. Cláusula Geral _ـ 40

1.5.2. Cláusulas Específicas ___ 42

II) Fundamentos da Tutela Judicial ___ 47

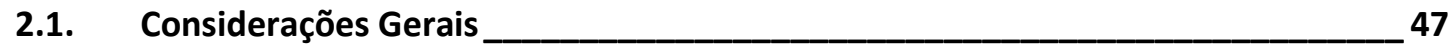

2.2. Relação de Inconstitucionalidade _____________ 48

2.2.1. Relação de Bipolaridade ___ 48

2.2.2. Relação Tripolar__ 51

2.3. Formas de Inconstitucionalidade ___ 54

2.3.1. Inconstitucionalidade por Ação ou por Omissão ___ 54

2.3.2. Inconstitucionalidade Total ou Parcial ___ 61

2.3.3. Inconstitucionalidade Explícita ou Implícita___ 66

2.4. Decisão de Inconstitucionalidade ___ 71

2.4.1. Quadro geral _ 71

2.4.2. Sentenças Simples__ 72

2.4.3. Sentenças Manipulativas___ 75 
3.1. Considerações Gerais

3.2. Arquitetura da Igualdade____ 88

3.2.1. Quadro Geral ___ 88

3.2.2. Diferenciação _ 90

3.2.3. Equiparação __ 92

3.2.4. Desconstrução __ 97

3.3. Modelo Unilateral ___ 99

3.3.1. Características ___ 99

3.3.2. Admissibilidade _ 101

3.3.3. Requisitos _ 107

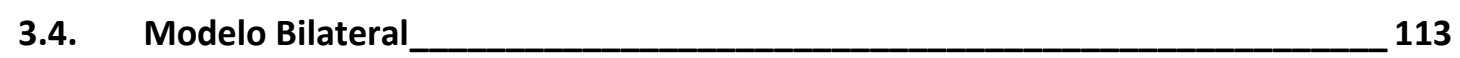

3.4.1. Características _ 113

3.4.2. Admissibilidade _ 116

3.4.3. Requisitos _ 122

IV) Aspectos Processuais___ 127

4.1. Considerações Gerais ______________ 127

4.2. Reparação Unilateral em Controle Concreto ____ 128

4.2.1. Características _ 128

4.2.2. Dilemas — 133

4.2.3. Crítica _ 138

4.3. Reparação Unilateral em Controle Abstrato____________ 143

4.3.1. Características __ 143

4.3.2. Dilemas _ 147

4.3.3. Crítica _ 153

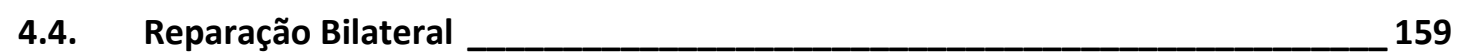

4.4.1. Características _ 159

4.4.2. Dilemas _ 163

4.4.3. Crítica _ 166

Conclusão __ 170

Bibliografia ___ 173 


\section{INTRODUÇÃ̃o}

\section{DELIMITAÇÃo DO TEMA}

A igualdade é tema recorrente na literatura, na história, na política, na filosofia, etc. Em nome dela, muitas posições são defendidas e muitas ações são justificadas, muito embora nem sempre ela seja bem compreendida. De qualquer forma, a Constituição brasileira de 1988 a garante: os modos pelos quais ela o faz e as implicações que essas previsões trazem para o ordenamento jurídico brasileiro é o tema desta pesquisa.

Com esta afirmação, um primeiro limite já fica claro: a dissertação terá como objeto de pesquisa as vigentes normas constitucionais relativas à igualdade. Não se trata, portanto, de uma análise do valor igualdade, mas sim do direito de igualdade. Ademais, não se trata de um estudo sobre a evolução histórica da igualdade nos movimentos constitucionalistas ${ }^{1}$, sejam eles europeus, norte-americano ou mesmo brasileiro, mas sim da igualdade estabelecida pela vigente Constituição nacional.

Ocorre que a igualdade se manifesta na Constituição em diversos dispositivos, de modo a regular múltiplas matérias, como os "princípios fundamentais" (título I), os "direitos e garantias fundamentais" (título II), a "tributação e o orçamento" (título VI), entre outros. Não se limita, portanto, a prever a igualdade como um dos direitos fundamentais assegurados pela Constituição, como se poderia imaginar. Daí surge a questão: esta será uma dissertação sobre a igualdade constitucional em geral, e sua jurisdição, ou sobre o direito fundamental da igualdade? Aqui, o próprio título oferece a resposta. Trata-se de uma dissertação que, não obstante sofrer a influência e utilizar elementos da teoria dos direitos fundamentais (em especial quando analisa $a$ estrutura e a natureza normativas da igualdade constitucional), na verdade transcende tal temática ${ }^{2}$. Por essa razão, preferiu-se fazer referência pura e simples à igualdade, e não ao direito fundamental de igualdade.

\footnotetext{
${ }^{1}$ Cf. Díez-Picaso, Sistema de derechos fundamentales, $2^{a}$ ed. Navarra: Editorial Aranzadi, 2005, pp. 191-193; Carmen Lúcia Antunes Rocha, O princípio constitucional da igualdade, Belo Horizonte: Editora Lê, 1990, pp. 28-59.

${ }^{2}$ Mesmo no âmbito dos direitos fundamentais, a alocação do tema igualdade é dificultosa e apresenta relevantes diferenças entre os autores de direito constitucional. Se, por um lado, Díez-Picaso a trata como um "direito fundamental em espécie" (cf. Sistema de derechos fundamentales, pp. 191-213), Jorge
} 
No intuito de promover um estudo abrangente da igualdade constitucional, em que as normas constitucionais analisadas não se limitam às normas de direitos fundamentais, optou-se por não adentrar em questões acerca do sentido e da forma dos direitos fundamentais ${ }^{3}$, das suas gerações e/ou dimensões ${ }^{4}$, das suas posições jurídicas subjetivas $^{5}$, entre outros. Por outro lado, normas de igualdade aplicáveis nos âmbitos previdenciário (igualdade na fruição de benefícios previdenciários), administrativo (igualdade de remuneração), tributário (igualdade na carga tributária), etc. serão relevantes para o estudo - apesar de estas áreas poderem ser articuladas com os direitos fundamentais, no sentido de se afirmar que todas as áreas do direito sofrem influência dos direitos fundamentais em uma dimensão objetiva ${ }^{6}$, isso exigiria um esforço metodológico que foge às propostas desta dissertação, que optou por incluir o viés jusfundamental da igualdade, mas a ele não se resumir.

Noutro giro, vale ressaltar que a dissertação não se resumirá a uma mera tentativa de compreensão da igualdade constitucional. Como dito, as implicações dessas normas sobre o ordenamento também são tema dessa dissertação. Assim, o trabalho a ser desenvolvido inclui não apenas a definição do que é a igualdade constitucional, mas também a investigação do que ela exige, o que poderá ser verificado a partir de uma análise da dinâmica relação existente entre a igualdade prevista em nível constitucional e as diferenciações e/ou equiparações feitas em âmbito legislativo infraconstitucional. Em suma, a dissertação não se limitará a formular conceitos e identificar noções

Miranda, por exemplo, a enquadra no estudo do "regime dos direitos fundamentais", mais especificamente no item sobre a "atribuição dos direitos", cf. Manual de direito constitucional, tomo IV: direitos fundamentais, $5^{\mathrm{a}}$ ed. Coimbra: Coimbra Editora, 2012, pp. 221-254. Em sentido próximo, José Joaquim Gomes Canotilho refere-se à igualdade em capítulo sobre o "regime geral dos direitos fundamentais", cf. Direito constitucional e teoria da Constituição, $2^{\mathrm{a}}$ ed. Coimbra: Coimbra Editora. 2001. pp. 426-432.

${ }^{3}$ Cf. J. J. Gomes Canotilho, Direito constitucional e teoria da Constituição, pp. 377-388.

${ }^{4} \mathrm{Cf}$. José Carlos Vieira de Andrade, Os direitos fundamentais na Constituição portuguesa de 1976, $3^{\mathrm{a}}$ ed. Lisboa: Almedina, 2004, pp. 15-68; Jorge Miranda, Manual de direito constitucional, tomo IV, pp. 12-32.

${ }^{5}$ Cf. Robert Alexy, Teoria dos direitos fundamentais, São Paulo: Malheiros, 2008, pp. 180-253.

${ }^{6}$ Cf. Ingo Wolfgang Sarlet, A eficácia dos direitos fundamentais, $8^{\mathrm{a}}$ ed. Porto Alegre: Livraria do Advogado Editora, 2007, pp. 167-177; Daniel Sarmento, Direitos fundamentais e relações privadas, $2^{\mathrm{a}}$ ed. Rio de Janeiro: Lumen Juris Editora, 2006, pp.105-140.

${ }^{7}$ Sobre o conceito de realização constitucional, José Joaquim Gomes Canotilho afirma o seguinte: "realizar a constituição significa tornar juridicamente eficazes as normas constitucionais. Qualquer constituição só é juridicamente eficaz (pretensão de eficácia) através da sua realização". Cf. Direito constitucional e teoria da constituição, p. 1200. 
substanciais acerca da igualdade, mas também objetivará a construção de uma metódica de realização ${ }^{7}$ do direito constitucional da igualdade.

Nesse propósito, será essencial para a dissertação o estudo do controle de constitucionalidade que é feito com parâmetro na igualdade. Aqui, mais um limite deve ser estabelecido: a dissertação não adentrará em todas as questões acerca do controle de constitucionalidade, mas tão somente naquelas questões que se relacionarem diretamente com a tutela da igualdade. Por isso, serão selecionados apenas alguns pontos de notório interesse para o tema, como é o caso do cotejo entre a inconstitucionalidade por ação em face da inconstitucionalidade por omissão, bem como a investigação da tipologia de sentenças utilizada pela jurisdição constitucional na reparação das violações à igualdade constitucional. Os demais tópicos sobre o controle de constitucionalidade não serão aprofundados, apenas serão expostos à medida que importarem para a sistematização da jurisdição constitucional da igualdade.

Ao fim e ao cabo, a dissertação esboçará métodos de verificação e correção das violações à igualdade constitucional. Nesse contexto, buscar-se-á uma sistematização dos modelos reparatórios da igualdade constitucional, examinando-se problemas de ordem institucional, ou seja, relativos à dinâmica da relação entre os poderes. Por último, serão investigados os aspectos processuais relativos aos modelos reparatórios delineados.

\section{JUSTIFICATIVA}

A escolha do tema "jurisdição constitucional da igualdade" para a dissertação de mestrado na Universidade de São Paulo decorre não de um, mas de alguns fatores. O primeiro deles, invariavelmente lembrado em introduções de textos acadêmicos, é o da relativa ausência de trabalhos sobre o tema. "Relativa", neste caso, porque o tema "igualdade", como se deve imaginar, é facilmente encontrado nas prateleiras de livrarias e bibliotecas, especialmente no âmbito de investigações políticas e filosóficas. Ocorre que, do ponto de vista jurídico, a igualdade não tem logrado a

\footnotetext{
${ }^{7}$ Sobre o conceito de realização constitucional, José Joaquim Gomes Canotilho afirma o seguinte: "realizar a constituição significa tornar juridicamente eficazes as normas constitucionais. Qualquer constituição só é juridicamente eficaz (pretensão de eficácia) através da sua realização". Cf. Direito constitucional e teoria da constituição, p. 1200.
} 
devida atenção. Afora algumas recentes discussões sobre a legitimidade de "discriminações positivas"8 e de "proteções a grupos vulneráveis", alguns trabalhos sobre o conceito geral de igualdade ${ }^{10}$ e apontamentos sobre a igualdade em estudos sobre o controle de constitucionalidade de "omissões parcias" 11 , não foram encontrados trabalhos nacionais que se propõem, tal como a presente dissertação, a sistematizar os elementos materiais e judiciais da igualdade sob a ótica dogmática do direito constitucional.

É certo que as investigações sobre as omissões parciais tocam essa temática, como dito acima. Entretanto, tais tratamentos estão longe de satisfazer o atento jurista que se debruça sobre o direito de igualdade. Conforme será demonstrado, a temática da igualdade é deveras complexa e rica para ser reduzida a um mero subcapítulo dos trabalhos sobre a inconstitucionalidade por omissão. Para se analisar com profundidade a igualdade enquanto parâmetro de controle de constitucionalidade, é imprescindível que se investigue o seu alcance normativo, relacionando-o com os fundamentos de sua tutela judicial, tarefa esta que ainda não foi feita no ambiente doutrinário brasileiro.

A segunda razão que justifica a escolha do tema é a importância de sua análise. Tal afirmação não resulta de um juízo subjetivo, mas sim de uma breve observação da realidade: a igualdade é tema recorrente na jurisprudência dos tribunais brasileiros $^{12}$. Pode-se cogitar que isto ocorre por conta de uma condição sociológica brasileira de reiterada violação do direito constitucional da igualdade. Embora isso talvez seja verdade - e é provável que seja -, não é objetivo deste trabalho examinar essa sugestiva hipótese. Diferentemente, esta pesquisa volta-se para uma outra causa da vasta

\footnotetext{
${ }^{8}$ Debates sobre a constitucionalidade da política de quotas nas universidades e do tratamento diferenciado oferecido às mulheres pela Lei Maria da Penha são exemplos disso.

${ }^{9}$ Assim podem ser considerados as mulheres, os negros, os povos indígenas, os homossexuais e transexuais, os estrangeiros e refugiados, as crianças e adolescentes, os portadores de necessidades especiais, entre outros.

${ }^{10}$ Cf. Celso Antônio Bandeira de Mello, O conteúdo jurídico do princípio da igualdade, $3^{\mathrm{a}}$ ed. São Paulo: Malheiros Editores, 2010; Humberto Ávila, Teoria da igualdade tributária, $2^{\mathrm{a}}$ ed. São Paulo: Malheiros, 2009.

${ }^{11}$ Em alguns cursos e teses sobre controle de constitucionalidade, é possível encontrar algumas referências à igualdade quando se trata do "controle das omissões parciais". Cf. Elival da Silva Ramos, Controle de constitucionalidade no Brasil: perspectivas de evolução, São Paulo: Saraiva, 2010, pp. 304-323; Clèmerson Merlin Clève, A fiscalização abstrata da constitucionalidade no direito brasileiro, $2^{\mathrm{a}}$ ed. São Paulo: Editora Revista dos Tribunais, 2000, pp. 350-361;

${ }^{12}$ Ao longo deste trabalho, serão investigados diversos acórdãos do Supremo Tribunal Federal.
} 
jurisprudência sobre a igualdade, qual seja, a sua abrangente eficácia em face do modus operandi da normatização infraconstitucional. É o que se demonstra a seguir.

A legislação, ao regulamentar a vida em sociedade estabelecendo comportamentos obrigatórios, permitidos e/ou proibidos, nada mais faz que i) selecionar, escolher, diferenciar circunstâncias e pessoas (hipótese) e ii) determinar uma conduta devida em face da ocorrência da hipótese descrita (consequente). Isso tudo no sentido de disciplinar condutas de acordo com finalidades relevantes. Ao fazer isso - e este é o ponto principal - a legislação imputa obrigações e concede direitos não de forma padronizada, mas sim de modos que variam em razão das situações, dos sujeitos envolvidos, das finalidades da norma, entre outros. A lei, enfim, diferencia para regular ${ }^{13}$.

Por conta dessa característica inerente ao direito positivo - de diferenciar situações e pessoas para conseguir regular condutas -, a igualdade pode ser examinada diante de incontáveis fatos jurídicos e, portanto, aparece cotidianamente nos tribunais. Para utilizar os mesmos exemplos citados no parágrafo anterior, é possível imaginar a apresentação, em esfera judicial, dos seguintes questionamentos: se todos são iguais, por que uns têm capacidade civil e outros não? Por que uns tem tratamento prioritário em face de outros? Por que alguns são penalmente responsáveis e outros não? Por que uns pagam mais tributos que outros? Por que uns recebem benefícios previdenciários e outros não? Por que uns têm uma remuneração maior que a de outros, inclusive no serviço público?

Por aí se vê que a importância do tema em exame decorre mais da própria natureza do processo de normatização do que por fatores extrajurídicos. Afinal, toda (ou quase toda) regulação pode ser questionada em face da igualdade. É dizer, sempre (ou quase sempre) é possível alegar a violação da igualdade quando a lei atribui direitos para uns e não para outros. Da mesma forma, invariavelmente será possível impugnar o estabelecimento de obrigações para uns e não para outros.

Um terceiro fator para a escolha do tema é complementar ao anterior: a determinação de observância da igualdade em nível constitucional e a consequente

\footnotetext{
${ }^{13}$ Constatação semelhante é feita por Celso Antônio Bandeira de Mello: "as leis nada mais fazem senão discriminar situações para submetê-las à regência de tais ou quais regras - sendo esta mesma sua característica funcional”. Cf. O conteúdo jurídico do princípio da igualdade, p. 11.
} 
inclusão desta nos quadrantes da ciência do direito constitucional. Isso é importante destacar, mesmo porque o tema desta dissertação não é apenas a igualdade, mas sim o direito constitucional de igualdade. Conforme será observado no decorrer da dissertação ${ }^{14}$, a Constituição brasileira não faz uma, mas sim várias referências à igualdade. Nesse sentido, e em razão da supremacia que a Constituição exerce no ordenamento normativo, os atos normativos infraconstitucionais devem respeitá-la em qualquer circunstância.

Disso decorre a necessidade premente de compreensão do significado da igualdade e, por conseguinte, das posições jurídicas que ela exige do sistema normativo infraconstitucional. Somente com a construção de um sólido modelo dogmático desse direito é que será possível examinar a constitucionalidade das diferenciações típicas do processo de normatização de condutas, tal como exposto supra. Apenas com o exame do alcance normativo da igualdade constitucional é que será possível afirmar quais das diferenciações normativas são, e quais não são, compatíveis com a igualdade. Novamente: é o conhecimento do direito constitucional da igualdade que permitirá o incremento de sua realização.

Como quarta e última justificativa, podemos citar as peculiaridades que envolvem o controle de constitucionalidade com parâmetro na igualdade.

Em nome da igualdade, diversas tutelas judiciais são requeridas. Algumas delas podem ser deferidas pelo poder judiciário sem maiores percalços, de acordo com os tradicionais mecanismos de controle de constitucionalidade. Um exemplo claro disso é a ação judicial que postula a declaração da inconstitucionalidade de um privilégio reputado contrário ao direito de igualdade. Nesta circunstância, uma sentença simples que declare a inconstitucionalidade por ação do ato legislativo que concedeu tal privilégio é suficiente para restaurar o estado de constitucionalidade. Ocorre que nem sempre será possível proceder dessa forma. Em determinados casos, a declaração simples de nulidade do ato contrário ao direito de igualdade não será suficiente para restabelecer o estado de igualdade constitucional. Ademais, nem sempre o órgão de jurisdição constitucional será competente para reparar a violação à igualdade constitucional. Essas e outras questões serão abordadas no momento adequado. Neste

\footnotetext{
${ }^{14}$ Em especial, no tópico 1.5 .
} 
contexto, importa somente destacar que a identificação desses problemas configura uma séria justificativa para abordagem do tema.

Portanto, é em face i) da relativa ausência de estudos sobre o tema, ii) da importância da igualdade em uma realidade normativa pautada em diferenciações, iii) da consagração em nível constitucional da igualdade, e iv) das peculiaridades do controle de constitucionalidade efetuado com parâmetro na igualdade que se justifica a escolha do tema "direito constitucional da igualdade".

\section{Metodologia}

Conforme já observado, o estudo da igualdade comporta múltiplas abordagens. É possível analisá-la de um ponto de vista filosófico, em que a igualdade aparece como uma categoria da moral; por uma perspectiva econômica, que prioriza o estudo das diferenças entre as pessoas no que tange ao acesso delas aos bens de consumo e/ou quanto ao bem-estar; em seu aspecto político, cujo viés é a análise da igualdade entre os cidadãos na formação da vontade política do Estado; por um prisma sociológico, em que se examina o grau de respeito à igualdade em determinada sociedade; entre outros.

Com efeito, a igualdade é tema recorrente nas ciências humanas. Já na Grécia antiga se discutia a igualdade, e isso não deixou de ser uma realidade dos tempos mais recentes. Ainda hoje, a igualdade permanece revestida de interesse especulativo nos mais diversos campos do conhecimento. Em especial, releva o debate da igualdade no campo da teoria política, seara em que a igualdade configura objeto de vasta produção científica, especialmente por ser considerada um critério de extrema relevância para a prática da justiça. Trata-se, aqui, de um estudo com viés especulativo, em que se atenta para a definição do que é igualitário de um ponto de vista valorativo, mas não normativo. "Quem merece o quê?”, “de que forma a equidade pode guiar a ideia de justiça”, entre outros, são questões que intrigam grandes autores da filosofia política $^{15}$.

\footnotetext{
${ }^{15}$ Dentre eles, podem ser citados: Michael Walzer, Esferas da justiça: uma defesa do pluralismo e da igualdade, São Paulo: Editora Martins Fontes, 2003; John Ralws, Uma teoria da justiça, São Paulo: Editora Martins Fontes, 2002; Ronald Dworkin, A virtude soberana: a teoria e a prática da igualdade,
} 
Todos esses enfoques são importantes e, de certa forma, exercem influências um sobre os outros. Contudo, nenhum deles configura o objeto central desta dissertação.

O enfoque deste trabalho é uma análise jurídico-dogmática ${ }^{16}$ da igualdade constitucional. Nesse sentido, atenta para a igualdade em relação a um determinado ordenamento jurídico, em especial suas normas de nível constitucional - aqui, a igualdade é investigada tal como formulada na Constituição brasileira de 1988 e aplicada pelo Supremo Tribunal Federal.

O objetivo não é singelo: identificar ferramentas lógico-jurídicas para desenvolver o sentido e a eficácia da igualdade constitucional perante o ordenamento jurídico infraconstitucional. Nesta missão, o trabalho adota uma perspectiva que é, ao mesmo tempo, analítica, empírica e normativa ${ }^{17}$. Analítica porque disseca o sistema constitucional da igualdade, define conceitos úteis para a racionalização do estudo, bem como explora a estrutura e a natureza das normas constitucionais de igualdade. Empírica porque também se preocupa com a práxis jurídica da igualdade, de modo a destacar questões não apenas legais, de mera cognição do direito legislado, mas também jurisprudenciais, de aplicação do direito da igualdade. Por fim, é normativa porque é crítica e propositiva, no sentido de que não se resume a descrever uma realidade, mas sim busca identificar pontos nodais e oferecer soluções a tais problemas.

Outro aspecto metodológico relevante diz respeito ao caráter científico que se pretende empreender. Esta é uma consideração relevante tendo em vista que não é difícil encontrar, inclusive em trabalhos jurídicos acadêmicos, um recorte metodológico que prioriza a demonstração do apreço político e social do objeto em estudo. Nestas condições, o autor costuma enfatizar o quanto é necessária e benéfica a aplicação

São Paulo: Martins Fontes, 2005; Samuel Fleischaker, Uma breve história da justiça distributiva, São Paulo: Martins Fontes, p. 2006; David Schmidtz, Os elementos da justiça, São Paulo: Editora Martins Fontes, 2009; Roberto Gargarella, As teorias da justiça depois de Rawls: um breve manual de filosofia política, São Paulo: Editora Martins Fontes, 2008; Michael Sandel, Justiça: o que é fazer a coisa certa, São Paulo: Editora Civilização Brasileira, 2012; entre outros.

${ }^{16}$ A dogmática, segundo Tercio Sampaio Ferraz Jr., "explica que os juristas, em termos de um estudo estrito do direito, procurem sempre compreendê-lo e torná-lo aplicável dentro dos marcos da ordem vigente. Essa ordem que lhes aparece como um dado, que eles aceitam e não negam, é o ponto de partida inelutável de qualquer investigação. Ela constitui uma espécie de limitação, dentro da qual eles podem explorar as diferentes combinações para a determinação operacional de comportamentos juridicamente possíveis". Cf. Introdução ao estudo do direito: técnica, decisão, dominação, $4^{\text {a }}$ ed. São Paulo: Atlas, 2003, p. 48.

${ }^{17}$ Cf. Robert Alexy, Teoria dos direitos fundamentais, p. 33. 
maximalista do seu objeto. No caso do tema escolhido, se esta fosse a abordagem definida, a igualdade passaria a ser encarada não como algo a ser compreendido, mas sim como algo a ser defendido, enaltecido, proclamado. Com isso, o trabalho receberia uma carga valorativa que, se por um lado, poderia aumentar seu poder de persuasão, por outro lado deixaria de explicar algumas noções essenciais para o desenvolvimento do tema, ou mesmo deixar de apresentar uma postura crítica acerca das decisões judiciais que são tomadas em nome da igualdade.

Construir um modelo objetivo e científico de aplicação da igualdade representa, portanto, a metódica desta dissertação. Estas considerações, que fundamentam a definição de um trabalho jurídico-dogmático, servem não somente para afastar cogitações externas à lógica jurídica, mas também para repudiar aproximações apologéticas do tema igualdade. A preocupação desta dissertação não é estética, tampouco ideológica.

Por fim, é válido ressaltar que, no intuito de apresentar um estudo analítico e empírico do direito constitucional da igualdade, optou-se por verificar, no desenvolvimento dos argumentos, tanto cogitações teoréticas extraídas da doutrina relevante, quanto reflexões feitas em decisões fundamentadas da jurisdição constitucional. Ocorre que, quanto a estas, é necessário fazer uma ressalva, no sentido de que as decisões a serem analisadas advêm, primordialmente, do arcabouço jurisprudencial do Supremo Tribunal Federal. Ora, é certo que a competência para realizar a jurisdição constitucional, no Brasil, é difusa. Mas isso não impede uma importante constatação: no Brasil, é o Supremo Tribunal Federal que exerce, na condição de órgão supremo do poder judiciário, a função de "juiz dos demais órgãos estatais, de árbitro supremo dos conflitos entre os poderes"18. Tal afirmação, embora mereça uma pesquisa a parte, explica o recorte metodológico. Afinal, o estudo aqui empreendido se pautará numa metodologia de concretização constitucional que somente um órgão com características de poder moderador ${ }^{19}$ pode realizar, pois é uma metodologia que leva em consideração não apenas o papel do poder judiciário na realização do direito constitucional da igualdade, mas também o papel do poder legislativo.

\footnotetext{
${ }^{18}$ Cf. Roger Stiefelmann Leal, O efeito vinculante na jurisdição constitucional, São Paulo: Saraiva, 2006, p. 37.

${ }^{19}$ Cf. Roger Stiefelmann Leal, O efeito vinculante na jurisdição constitucional, pp. 38-39.
} 
Tal delineamento, embora contenha elementos de mérito, merece a devida atenção mesmo como razão metodológica. Tendo em vista que o tema a ser examinado, em especial quando trata da jurisdição constitucional, está intrinsecamente ligado a aspectos funcionais referentes à divisão de competências para concretizar a Constituição, considera-se de extrema relevância destacar que a presente dissertação abonará aquilo que Friedrich Müller chamou de critério da correção funcional-jurídica da Constituição $o^{20}$. Trata-se de um método, de acordo com o próprio autor, orientado "segundo a distribuição das tarefas entre os poderes legislativo e judiciário", de sorte a configurar verdadeira "metódica de titulares de funções" $" 21$. Em outras palavras, é uma metódica não apenas judiciária, no sentido de buscar respostas judiciais prontas e acabadas para toda e qualquer questão constitucional relevante, mas sim uma metódica que compreende, e leva a sério, a divisão de tarefas delineada pelo constituinte, motivo pelo qual, muitas vezes, entende como solução constitucionalmente adequada a transferência, ao legislador, da missão de solucionar vícios de inconstitucionalidade. Consoante se observará, essa será a solução para parte das violações ao direito constitucional da igualdade, mas isto sim já é uma questão explicitamente meritória, não cabendo maiores explicações em termos de metodologia.

\section{ITINERÁRIO}

A dissertação se dividirá em quatro capítulos. O primeiro deles tratará de aspectos materiais relacionados ao alcance normativo da igualdade constitucional, enquanto que o segundo investigará os fundamentos de sua tutela judicial. Por sua vez, o terceiro capítulo enfocará a reparação das afrontas à igualdade, tendo como propósito a construção de modelos adequados de identificação dos vícios de inconstitucionalidade, bem como de sanção destes. Por fim, o quarto e último capítulo examinará os aspectos processuais dos modelos reparatórios da igualdade.

A seguir, são elencadas as principais questões a serem discutidas em cada um dos capítulos, precedidas por uma breve explicação das razões que justificam suas investigações.

\footnotetext{
${ }^{20}$ Cf. Friedrich Müller, Metodologia do direito constitucional, $4^{\mathrm{a}}$ ed. São Paulo: Editora Revista dos Tribunais, 2010, p. 35.

${ }^{21}$ Cf. Friedrich Müller, Metodologia do direito constitucional, p. 52.
} 
Inicialmente, este trabalho analisará o alcance normativo das normas constitucionais de igualdade. Neste escopo, serão relevantes estudos sobre: i) as propriedades normativas da igualdade, como sua estrutura, conteúdo e natureza normativos; ii) as dimensões contrapostas da igualdade; iii) os dispositivos constitucionais atinentes à igualdade. No primeiro item, serão examinadas as características da igualdade enquanto norma, o que ensejará uma correta percepção do seu funcionamento como parâmetro de controle de constitucionalidade. O segundo item, ao expor as dimensões contrapostas relativas ao direito de igualdade, também permitirá o desenvolvimentos de ferramentas metódicas para sua realização. Por último, o item sobre os preceitos constitucionais que disciplinam a matéria da igualdade permitirá o reconhecimento dos parâmetros positivos da igualdade. A partir dele, será possível articular o direito constitucional da igualdade de um modo mais detalhado e constitucionalmente vinculado.

Basicamente, será um capítulo voltado para responder às seguintes indagações:

- Quais as propriedades normativas da igualdade? Quais elementos estruturais devem ser considerados para a realização de um teste de igualdade? Qual a sua natureza normativa?

- Quais são as dimensões possíveis da igualdade? Qual a diferença entre igualdade fática e normativa, formal e material, paritária e proporcional?

- Quais são as normas constitucionais relativas ao direito de igualdade? De que forma elas atuam sobre o ordenamento jurídico infraconstitucional?

Afora esses aspectos substanciais relativos ao direito constitucional da igualdade, existem também questões jurisdicionais de grande relevância para o tema que se apresenta. Isso porque não basta conhecer o alcance normativo do direito de igualdade para poder aplicá-lo de modo sistemático e coerente. Para tanto, além de dominar o conteúdo das normas constitucionais relativas à igualdade, será preciso também construir um modelo constitucionalmente adequado de reconhecimento e sanção das violações à igualdade constitucional. Nesta missão, sobressai a importância de um estudo das bases teóricas de uma tutela judicial da igualdade.

No segundo capítulo, as principais questões a serem respondidas serão: 
- Como se desenvolve o controle de constitucionalidade com fundamento na igualdade?

- Quais são as formas pelas quais se manifestam as violações à igualdade?

- As sentenças declaratórias simples de nulidade são aptas a reparar a inconstitucionalidade das normas violadoras da igualdade estabelecida em nível constitucional?

Definidas as características materiais da igualdade constitucional, bem como as particularidades de sua jurisdição, parte-se para o estudo dos modelos institucionais de reparação da igualdade. Assim, tendo em vista as exigências da igualdade e as técnicas utilizadas em sua jurisdição, busca-se a construção de uma metódica funcional de realização da igualdade constitucional que tenha condições de, ao mesmo tempo, fazer prevalecer a supremacia da Constituição tanto no que respeita às suas normas de fundo, como a igualdade, quanto no que tange às suas normas de procedimento, como a divisão de funções entre os poderes. Para isso, serão articuladas algumas noções quanto ao grau de vinculação que a Constituição exerce em face do legislador em matéria de igualdade, o que permitirá uma definição dos contornos da discricionariedade conformativa do legislador nesta matéria. Nesse contexto, serão descritos dois modelos jurisprudenciais de tratamento das violações à igualdade constitucional, o da reparação direta e unilateral e o modelo bilateral de reparação.

Antes de se expor tais modelos, será preciso classificar a jurisprudência do Supremo Tribunal Federal sobre o assunto, em tópico denominado "arquitetura da igualdade". Tal classificação será relevante para se demonstrar que a igualdade não permite apenas um, mas sim vários modos de reparação: atuando a igualdade constitucional como exigência de tratamento equiparado, o controle sobre diferenciações poderá ser feito no sentido de se reduzir o regime mais vantajoso até o patamar do menos vantajoso, de se ampliar o regime menos benéfico até o nível do regime mais benéfico, ou mesmo de se eliminar ambos os regimes, nivelando-os "por baixo". Já se a igualdade demandar tratamento desigual entre desiguais, deverá ser promovida uma diferenciação entre regimes originalmente tratados de maneira equivalente. Essas e outras questões serão objeto do item sobre a "arquitetura da igualdade". 
As principais questões a serem analisadas no terceiro capítulo da dissertação são:

- Quais são as soluções possíveis para se restaurar o estado de igualdade?

- Quais são os modelos reparatórios passíveis de utilização para jurisdição constitucional da igualdade? Em que situações eles devem ser empregados?

Ocorre que o exame da competência reparatória em sede de igualdade não esgota a temática da efetiva e concreta correção das violações à igualdade constitucional. Isso porque existem aspectos processuais que, nada obstante o caráter eminentemente formal dos mesmos, refletem sobremaneira na metodologia jurisdicional de restauração da igualdade. Prova disso é que, dependendo do instrumento processual utilizado, serão distintos o objeto submetido a controle, bem assim os efeitos das decisões proferidas.

Consoante será oportunamente analisado, o fato do controle de constitucionalidade se dar na forma concreta, em procedimento incidental, ou na forma abstrata, em procedimento principal, tem profundas consequências no processo de reparação das afrontas ao direito de igualdade. Demais disso, o procedimento corretivo bilateral, cujos fundamentos teóricos e funcionais são objeto do capítulo terceiro, constitui mecanismo recente no âmbito da jurisdição constitucional, razão pela qual é objeto de dúvidas e incertezas não apenas quanto à sua efetividade, mas também quanto ao seu procedimento.

As principais questões a serem analisadas no quarto capítulo são:

- Quais as características e dilemas do processo reparatório efetuado em controle concreto de constitucionalidade?

- Quais as características e dilemas da reparação realizada na via abstrata e direta de controle de constitucionalidade?

- Como se dá o processo reparatório bilateral? Quais são suas características essenciais e os dilemas delas decorrentes? 


\section{I) IGUALDAde E CONSTITUIÇÃo}

1.1. Considerações gerais; 1.2. Propriedades normativas; 1.2.1. Estrutura normativa; 1.2.2. Natureza normativa; 1.3. Dimensões contrapostas; 1.3.1. Igualdade fática $\mathrm{X}$ normativa; 1.3.2. Igualdade formal $\mathrm{X}$ material; 1.3.3. Igualdade paritária X proporcional; 1.4. Conceito de Igualdade; 1.5. Igualdade na Constituição de 1988; 1.5.1. Cláusula geral; 1.5.2. Cláusulas específicas.

\subsection{CONSIDERAÇÕES GERAIS}

O desenvolvimento do presente estudo solicita, como primeira etapa de seu arranjo, a análise de aspectos substantivos e conceituais do direito constitucional de igualdade. Isso porque a compreensão do significado jurídico da igualdade e, por conseguinte, das posições jurídicas que ela exige do sistema normativo infraconstitucional, auxiliará no desenvolvimento do trabalho. Afinal, somente com a elucidação de algumas noções essenciais da igualdade é que será possível examinar a constitucionalidade das diferenciações e equiparações típicas do processo de normatização de condutas.

Nesse escopo inicial, serão delineadas as propriedades normativas do direito de igualdade, quais sejam, sua estrutura e sua natureza normativa. Em seguida, serão objeto de análise algumas das dimensões da igualdade. A partir dessas análises, será fixado um conceito de igualdade, o qual terá a função precípua de orientar as abordagens sobre a tutela judicial da igualdade. Por fim, serão tecidos alguns comentários acerca dos dispositivos da Constituição brasileira de 1988 que tratam da igualdade. 


\subsection{PROPRIEDADES NORMATIVAS}

\subsubsection{Estrutura Normativa}

Do ponto de vista lógico e descritivo, igualdade consiste na relação ${ }^{22}$ de parcial coincidência de grandezas entre sujeitos postos em comparação ${ }^{23}$. Trata-se da semelhança existente entre sujeitos quanto à determinada característica. Assim, numa comparação baseada em qualidades físicas, dois sujeitos podem ser considerados iguais quanto à altura, quanto à cor dos olhos, quanto ao gênero, entre outros, sendo estas as grandezas coincidentes. Disso se infere os primeiros elementos necessários da relação de igualdade: sujeitos ${ }^{24}$ e critério de comparação.

No que tange aos sujeitos, deve-se observar que a igualdade é uma relação estabelecida entre uma pluralidade deles, e não a um único sujeito em $\mathrm{si}^{25}$. Para se demonstrar esta ideia, não é preciso grande desenvolvimento argumentativo, bastando pensar na incoerência intrínseca da seguinte afirmação: "o sujeito A é igual”. Ou ainda, "o sujeito B tem direito a ser igual". Diante de tais assertivas, visivelmente incompletas, o questionamento é inevitável: “igual a quem?”, ou “igual a que?". Dessa alteridade de sujeitos infere-se que igualdade implica em comparações. Vale dizer, algo ou alguém somente pode ser considerado igual a outro algo ou alguém. O raciocínio parece óbvio, mas é digno de destaque, pois repercutirá em toda sistematização deste trabalho.

Pelo exposto, constata-se que igualdade não se confunde com identidade, e esta também é uma constatação preciosa. Quando se afirma que dois objetos ou pessoas são iguais, o que se afirma é que ambos possuem alguma característica em comum, mas não que são sujeitos idênticos. Neste caso, a semelhança seria total, ou seja, haveria dois elementos de mesma natureza que, inclusive, prescindiriam de uma comparação.

\footnotetext{
${ }^{22}$ Cf. Humberto Ávila também se pauta na ideia de relação: "O caso paradigmático anteriormente analisado demonstra que a igualdade é uma relação entre dois ou mais sujeitos em razão de criterio que serve a uma finalidade. Cf. Teoria da igualdade tributária, p. 40; No mesmo sentido, cf. Pérez Luño, Dimensiones de la igualdad, $2^{\mathrm{a} e d . ~ M a d r i: ~ D y k i n s o n, ~ 2007, ~ p . ~} 18$.

${ }^{23}$ Cf. Antonio Enrique Pérez Luño, Dimensiones de la igualdad, p. 17.

${ }^{24}$ Vale ressaltar, porém, que por "sujeitos" não se deve compreender apenas pessoas físicas, mas sim entidades jurídicas em geral (incluindo fatos, situações, atividades). Nesse sentido, Cf. Humberto Ávila, Teoria da igualdade tributária, p. 43.

${ }^{25}$ Markus González Beilfuss: "a igualdade normativa pressupõe necesariamente uma comparação entre dois ou mais regimes jurídicos que atuam como termos de comparação". Cf. Tribunal Constitucional y reparación de la discriminación normativa, Madri: Centro de Estudios Políticos y Constitucionales, 2000, p. 21.
} 
Nesse contexto, é interessante observar que só se pode falar em igualdade quando há singularidade, ou seja, quando se trata de uma pluralidade de sujeitos, cada um com características próprias que o tornam singulares. Tal paradoxo se explica pelo fato de que só é cabível uma análise de igualdade quando dois ou mais sujeitos apresentam-se distintos, e que, não obstante suas peculiaridades, podem ser iguais em relação a determinadas características e diferentes quanto a outras. Em suma, para haver uma comparação com base na igualdade, é preciso que haja diferença.

Além da alteridade de sujeitos, a igualdade também se pauta num segundo elemento, já citado: o critério (ou medida, ou fator) de comparação ${ }^{26}$. A razão disso é que, quando dois sujeitos são colocados como iguais ou desiguais, na verdade o que se faz é compará-los sob determinado aspecto, pois as pessoas ou situações não podem ser consideradas iguais ou desiguais com relação a tudo (novamente, se trataria de um exame de identidade e não de igualdade), mas sim em função de um critério específico $^{27}$.

Como exemplo: um homem $\mathrm{H}$ e uma mulher $\mathrm{M}$, sujeitos distintos, são colocados em comparação. Quanto ao gênero, que serve como critério, medida ou fator de comparação, constata-se a diferença entre os sujeitos. Mas isso não significa diferença em tudo, pois o mesmo homem e a mesma mulher podem ser comparados utilizando-se de outros critérios ${ }^{28}$. Basta citar uma comparação quanto à remuneração de ambos. Neste caso, poderá haver igualdade, sendo irrelevante a análise do gênero, e pertinente a averiguação dos ingressos financeiros dos sujeitos. Em conclusão, os sujeitos são distintos quanto ao gênero, mas iguais quanto à remuneração. Noutro giro, podemos citar apenas dados físicos de $\mathrm{H}$ (homem, 35 anos, 1,70m, olhos azuis, etc.) e M (mulher, 27 anos, 1,70m, olhos castanhos). Com base nestes dados, é possível

\footnotetext{
${ }^{26}$ Quanto a este aspecto, Humberto Ávila fala em "medida de comparação" e seu "elemento indicativo" (cf. Teoria da igualdade tributária, pp. 43-63). Celso Antônio Bandeira de Mello a chama de "fator de discriminação" (cf. O conteúdo jurídico do princípio da igualdade, p. 23).

${ }^{27}$ Robert Alexy é categórico: "dois indivíduos ou duas situações nunca são iguais em todos os aspectos. A igualdade - tanto quanto a desigualdade - entre indivíduos e situações é sempre uma igualdade - ou uma desigualdade - em relação a determinadas características"; Cf. Teoria dos direitos fundamentais, p. 399. Na mesma esteira, cf. Humberto Ávila, Teoria dos princípios, p. 172.

${ }^{28}$ Nesse sentido, afirma Humberto Ávila: "os sujeitos, objeto de comparação, devem, no entanto, ser comparados ou medidos com referência a uma medida comum de comparação. Os sujeitos podem ser comparados com base na idade, no sexo, na capacidade econômica, e assim sucessivamente". Cf. Teoria da igualdade tributária, p. 43.
} 
afirmar que ambos são iguais apenas no que tange à altura, sendo diferentes quanto ao gênero, idade e profissão.

Até aqui, verificou-se alguns dos elementos pertinentes à relação de igualdade, quais sejam, a pluralidade de sujeitos e o critério de comparação. Ocorre que o direito de igualdade, como toda norma, trabalha com a lógica prescritiva do dever ser. Destarte, sua preocupação não é a existência de igualdade ou desigualdade entre dois sujeitos. Embora esta constatação seja relevante, não é ela que pauta a norma da igualdade, mas sim a verificação se os sujeitos comparados devem ser tratados de modo igual ou desigual. E para que essa verificação seja possível, é preciso analisar mais um elemento estrutural da igualdade, qual seja, a finalidade ${ }^{29}$ da regulação normativa, que nada mais é senão o objetivo que justifica a atribuição de direitos e obrigações de modo equivalente ou diferenciado.

A finalidade, seja ela compreendida como um estado de fato a ser atingido $^{30}$, ou então interesses almejados pelo ordenamento ${ }^{31}$, corresponde ao fiel da balança na estrutura da igualdade enquanto norma. É ela que indicará se os sujeitos colocados em comparação, semelhantes em relação a determinadas medidas e diferentes em relação a outras, devem ser tratados do mesmo modo ou de modos distintos. É ela, enfim, que determinará quais os critérios relevantes para fins de comparação à luz da igualdade.

Para ilustrar o raciocínio, retomem-se os sujeitos $\mathrm{H}$ e $\mathrm{M}$, distintos quanto ao gênero, mas iguais quanto à altura e à remuneração. Tratando-se de uma regulação normativa que visa definir a tributação incidente sobre o rendimento dos mesmos, avultam as características relativas à capacidade contributiva (fiscalidade) e/ou características socioeconômicas a serem compensadas ou fomentadas (extrafiscalidade). De qualquer modo, dificilmente o gênero, ou a altura, servirão de critérios para uma análise comparativa de igualdade. Por outro lado, tratando-se de uma regulação normativa voltada para a definição dos requisitos para a concessão de proventos de

\footnotetext{
${ }^{29}$ Sobre o assunto, constata Humberto Ávila: "se é a finalidade a ser perseguida que, em última análise, vai permitir verificar a correção da medida de comparação utilizada, a sua definição assume extrema relevância, pois a sua manipulação pode significar não apenas deixar de promover uma finalidade constitucionalmente posta, como expressar a restrição oblíqua da própria igualdade". Cf. Teoria da igualdade tributária, p. 63.

${ }^{30}$ Cf. Humberto Ávila, Teoria da igualdade tributária, p. 63.

${ }^{31} \mathrm{Cf}$. Celso Antônio Bandeira de Mello, O conteúdo jurídico do princípio da igualdade, p. 41.
} 
aposentadoria $^{32}$, ou então para definir o alcance de benefícios previdenciários relativos à maternidade/paternidade ${ }^{33}$, pode despontar a relevância do critério gênero. No mesmo sentido, para um concurso de ingresso numa carreira que dependa do porte físico, como polícia civil, guarda nacional, entre outros, pode vir a ser utilizado o critério "altura" como parâmetro para a definição do tratamento jurídico ${ }^{34}$.

É certo que, na prática, as finalidades que guiam as regulações normativas nem sempre aparecem explícitas e isoladas no ordenamento jurídico, tampouco incidem harmonicamente. Na realidade, as finalidades determinantes para uma regulação são plurais e, ao interagirem entre si, podem encaminhar soluções sintonizadas, ou mesmo antagônicas. Assim, a incidência de uma finalidade arrecadatória (físcal) leva a uma determinada postura, enquanto que uma finalidade corretiva (extrafiscal) pode levar a uma solução oposta. Do mesmo modo, num processo seletivo público (concurso ou licitação), uma finalidade técnica pode levar a um encaminhamento totalmente contrário àquele correspondente a uma finalidade compensatória, criada para beneficiar grupos menos favorecidos.

De todo modo, esta análise será útil para se determinar quais elementos devem ser considerados quando se examinam casos concretos que envolvem o direito de igualdade. Conforme se notará, a casuística relativa a este direito pode ser reduzida a uma relação entre os poucos elementos citados. Por esse prisma, a igualdade revela-se como um arquétipo que permite ao observador organizar elementos e, com isso, verificar se há ou não compatibilidade com o direito de igualdade. Isso não deve levar

\footnotetext{
${ }^{32}$ São típicos os casos que discutem se homens e mulheres fazem jus ao mesmo tratamento em termos de direitos à pensão. Nesse sentido, cite-se o acórdão proferido no RE $493.892 \mathrm{AgR} / \mathrm{RN}$, que afirmou o direito dos viúvos varões à receber pensão por morte de suas cônjuges, mesmo em caso de óbito anterior à Lei 8.213/91, haja vista que a Constituição "equiparou homens e mulheres para efeito de pensão por morte". Cf. RE 493892 AgR / RN - RIO GRANDE DO NORTE; Relator(a): Min. TEORI ZAVASCKI; Julgamento: 27/08/2013; Órgão Julgador: Segunda Turma.

${ }^{33}$ Exemplo disso é o julgamento da Ação Direta de Inconstitucionalidade $\mathrm{n}^{\circ} 1.946$, que tratou da constitucionalidade da abrangência do teto previdenciário (artigo 14 da Emenda Constitucional n ${ }^{\circ} 20$, de 1998) a todos os benefícios do Regime Geral de Previdência Social. Neste, julgou-se inconstitucional a submissão do benefício da licença maternidade ao teto da previdência social, sob o fundamento de que, ao definir que o empregador deveria arcar com os custos de manutenção da remuneração integral das gestantes, haveria uma inibição na contratação de mulheres, de modo a violar o art. $7^{\circ}$, inc. XXX, da Constituição. Cf. ADI 1946 / DF - DISTRITO FEDERAL; Relator(a): Min. SYDNEY SANCHES; Julgamento: 03/04/2003; Órgão Julgador: Tribunal Pleno.

${ }^{34}$ Sobre o assunto, já julgou o Supremo Tribunal Federal que a exigência de altura mínima para ingresso na carreira de delegado de polícia viola o princípio da isonomia. Cf. RE 140889 / MS - MATO GROSSO DO SUL; Relator(a): Min. MARCO AURÉLIO; Relator(a) p/ Acórdão: Min. MAURÍCIO CORRÊA; Julgamento: 30/05/2000; Órgão Julgador: Segunda Turma.
} 
ao entendimento de que a igualdade pode ser resumida a uma fórmula vazia ${ }^{35}$, mas sim à compreensão de que atestar quais tratamentos normativos estão, e quais não estão, em consonância com a igualdade exige uma atividade intelectiva no sentido de relacionar sujeitos de acordo com critérios e finalidades.

Por fim, vale ressaltar que todos esses elementos normativos remontam ao direito de igualdade enquanto estrutura lógica comparativa e, por isso, compõem um importante método para o teste de igualdade. Isto é, a correlação entre esses elementos configura, por si só, um parâmetro essencial para a verificação do modelo regulatório exigido pela igualdade, pois a própria pertinência lógica entre os sujeitos postos em comparação, o critério utilizado e a finalidade almejada já enseja um posicionamento relativo à adequação da comparação com o direito de igualdade ${ }^{36}$.

\subsubsection{Natureza Normativa}

No item anterior, delineou-se a igualdade como uma estrutura complexa composta de três elementos básicos (sujeitos, critério e finalidade), os quais devem ser articulados entre si para que um exame de igualdade possa ser realizado.

Das noções firmadas, infere-se que a igualdade não tem a força de, por si só, definir condutas prontas e acabadas. Pelo contrário, ela é uma norma maleável de acordo com as circunstâncias do caso concreto, a ponto de depender destas para fazer sentido. Assim, o direito de igualdade, conjecturado e afirmado em abstrato, isolado de uma situação específica, não permite desvendar uma conduta lícita ou ilícita.

Para demostrar essa afirmação, basta ter em mente que eventual afirmação no sentido de que "um sujeito $\mathrm{X}$ tem direito de igualdade" pouco, ou nada, quer dizer,

\footnotetext{
${ }^{35}$ Maria Glória F. P. D. Garcia faz a mesma ressalva: "Não obstante tal facto, há quem chame a atenção para a ausência de conteúdo do princípio da igualdade, considerando-o uma fórmula vazia (Leerformelcharakter), incapaz, consequentemente, de empreender qualquer tarefa de garantia contra excessos praticados no exercício do poder público"; cf. Estudos sobre o princípio da igualdade, Coimbra: Edições Almedina, 2005, p. 30. Do mesmo modo, Humberto Ávila assevera: "Até serem estabelecidas quais as semelhanças e as diferenças que devem ser consideradas relevantes, a igualdade continuará uma 'fórmula vazia"'. Cf. Teoria da igualdade tributária, p. 140.

${ }^{36}$ Celso Antônio Bandeira de Mello: "o ponto modular para exame da correção de uma regra em face do princípio isonômico reside na existência ou não de correlação lógica entre o fator erigido em critério de discrímen e a discriminação legal decidida em função dele". Cf. O conteúdo jurídico do princípio da igualdade, p. 37.
} 
ao menos quando tomada isoladamente ${ }^{37}$. É diferente, por exemplo, quando se afirma que o mesmo sujeito tem direito à vida, ou à segurança, ou à liberdade. Aqui, é possível extrair algumas noções jurídicas tão-somente a partir dessas declarações, por mais que também existam controvérsias acerca da extensão do direito à vida, à segurança ou à liberdade. Já no que tange à igualdade, a norma que dela resulta somente pode ser verificada com o exame do contexto em que ela se insere. Seria necessário, portanto, acrescer outros elementos normativos à afirmação de que "X tem direito de igualdade". Afinal, o direito de igualdade se daria em face de quem? Quais seriam os tratamentos jurídicos que se reputam abrangidos pelo direito de igualdade? Essas e outras perguntas não podem ser respondidas mediante uma interpretação estanque do direito de igualdade. Conforme se afirmou outrora, o exame da igualdade requer uma análise comparativa entre dois sujeitos distintos, ou entre dois regimes normativos.

Todas essas cogitações indicam que o direito de igualdade possui uma natureza normativa peculiar. Ao invés de definir, diretamente, obrigações, permissões e proibições, a igualdade exprime-se em norma que, na realidade, baliza a definição dos regimes jurídicos infraconstitucionais. Disso decorre que o direito de igualdade incide não sobre as condutas das pessoas, proibindo, autorizando ou obrigando a realização de determinados comportamentos, mas sim regula a própria produção do Direito, exigindo que, seja na criação de regimes jurídicos, seja na aplicação destes, resultem relações compatíveis com a igualdade.

A qualidade de norma "indireta", coordenadora da relação entre proposições jurídicas, não é novidade. Com efeito, muitas são as teorias que classificam as normas pela natureza e função exercidas no ordenamento, consignando a existência de normas que não têm a função, propriamente dita, de regular condutas, mas sim de ordenar o próprio processo de criação e aplicação do direito. Exemplo disso são as chamadas normas de estrutura, ou de competência ${ }^{38}$, as quais, segundo Norberto Bobbio, se voltam para a conformação do Direito em si, e não para a regulamentação dos fatos da

\footnotetext{
${ }^{37}$ Pontes de Miranda faz consideração semelhante: "Menos fácil é definir-se a igualdade, conceito lógico e matemático, do que liberdade, conceito psicossociológico, e democracia, conceito que somente aparece no grupo social. Porque se tem de precisar em que é que se hão de considerar iguais os homens. Dizê-los ‘iguais', sem mais explicações, de pouco adiantaria”. Cf. Democracia, liberdade, igualdade, p. 573.

${ }^{38}$ Sobre o assunto, defende Norberto Bobbio: em todo ordenamento, ao lado das normas de conduta, existe um outro tipo de normas, que se costuma chamar de norma de estrutura ou de competência. São aquelas normas que não prescrevem a conduta que se deve ter ou não mas prescrevem as condições e os procedimentos por meio dos quais são emanadas normas de conduta válidas. Cf. Teoria geral do direito, São Paulo: Martins Fontes, 2007, p. 186.
} 
realidade. Do mesmo modo, podem ser citadas as chamadas normas secundárias ${ }^{39}$, no sentido atribuído por Herbert Hart.

Por regular a disposição e o conteúdo de outras normas, o direito de igualdade pode receber o qualitativo de norma formal $^{40}$. Isso porque, desprovido de sentido normativo direto e independente, o direito de igualdade apresenta-se como forma apta a estruturar a relação entre outras normas, de modo a avaliar se, entre elas, há pertinência lógica entre critérios e finalidades. Indo além, o direito de igualdade (ao menos de acordo com a estrutura firmada anteriormente) pode ser considerado uma metanorma, justamente porque "verte parâmetros para a aplicação de outra"41.

Outra denominação que indica a natureza própria do direito de igualdade é sua qualificação como norma estruturante ${ }^{42}$. Tal adjetivo é adequado à medida que a igualdade configura uma norma de coesão do sistema jurídico, e não, propriamente, uma norma do seu repertório ${ }^{43}$. Com o escopo de harmonizar a relação entre as demais normas, a igualdade também pode ser considerada uma norma de coerência do ordenamento, objetivamente resguardado ${ }^{44}$.

Cabe ressaltar que o direito de igualdade, apesar de não possuir um sentido normativo usual, designativo de direitos e obrigações por si próprio, mas sim uma natureza metanormativa, formal, estruturante, não indica que ele tenha uma importância menor no sistema jurídico ${ }^{45}$. Muito pelo contrário, tendo em vista que sua abrangência

\footnotetext{
${ }^{39}$ Cf. Herbert Hart, O conceito de direito, São Paulo: Martins fontes, 2009, p. 129.

${ }^{40}$ Afirma Humberto Ávila: "É preciso esclarecer, porém, que, mesmo nessa hipótese, a igualdade é, novamente, um conceito comparativo e relacional, relativamente a algo, não determinado. Formal, portanto. Mas útil, é claro”. Cf. Humberto Ávila, Teoria da igualdade tributária, pp; 143-144.

${ }^{41}$ Cf. Humberto Ávila, Teoria da igualdade tributária, p. 134.

${ }^{42}$ Jorge Reis Novais elenca a igualdade como um dos "princípios constitucionais estruturantes". Cf. Os princípios constitucionais estruturantes da República Portuguesa, Coimbra: Coimbra Editora, 2004, pp. 101 e ss.

${ }^{43}$ Elival da Silva Ramos: "No sentido máximo de generalidade e abstração, os princípios constitucionais configuram regras estruturais do ordenamento, não integrando o seu conjunto de normas, 'ou seja, os princípios gerais, na sua forma indefinida, compõem a estrutura do sistema, não o seu repertório'. 'São regras de coesão que constituem as relações entre as normas como um todo"”. Cf. A inconstitucionalidade das leis, p. 133.

${ }^{44}$ Livio Paladin: "i giudizi costituzionali d'eguaglianza non sono instaurabili da coloro che tendono a servirsi dell' art. 3, $1^{\circ}$ co., Cost., per ampliare situazioni soggettive di vantaggio; bensì hanno di mira la coerenza dell'ordinamento giuridico, oggetivamente riguardato". Apud, Alfonso Celotto, "Il controlo di eguaglianza sulle leggi in Italia”, In: Manuel Carrasco Durán, Francisco Javier Pérez Royo, Joaquín Urías Martínez, Manuel José Terol Becerra (coord.), Derecho constitucional para el siglo XXI : actas del VIII Congreso Iberoamericano de Derecho Constitucional, Vol. 1, 2006, p. 2.

${ }^{45}$ No mesmo sentido, afirma Humberto Ávila: "O essencial, para concluir-se este ponto, é que dizer que a igualdade é formal, por ser estrutural, não é o mesmo que afirmar que ela é menos valiosa". Cf. Teoria da igualdade tributária, p. 144.
} 
provoca a irradiação de seus efeitos sobre todo o ordenamento jurídico, imputando-lhe uniformidade, coerência, equilíbrio e proporção, o direito de igualdade tem uma potencialidade contundente. Deve, portanto, ser manejado com zelo e diligência, sob pena de se tornar instrumento para toda e qualquer fundamentação jurídica. Justamente por isso, é necessário conhecer o seu funcionamento, avaliando a influência de sua natureza normativa sobre o sistema jurídico.

\subsection{Dimensões}

\subsubsection{Igualdade Fática $X$ Normativa}

Afirmar que duas pessoas são iguais é completamente diferente da afirmação de que duas pessoas devem ser tratadas de modo igual. Na primeira assertiva, a igualdade é veiculada em linguagem descritiva, representativa do mundo do ser. $\mathrm{Na}$ segunda, a linguagem é prescritiva, típica do mundo jurídico do dever ser ${ }^{46}$. Embora exista uma relação entre ambas, elas possuem peculiaridades relevantes que devem ser destacadas, de modo a distinguir os seus sentidos.

Já se ressaltou que, diferentemente da relação de identidade (em que dois sujeitos não apresentam quaisquer diferenças, sendo idênticos entre si), a igualdade pressupõe a análise comparativa de sujeitos singulares que, em geral, podem ser considerados iguais ou desiguais, a depender do critério que se utiliza. Para ficar apenas em aspectos físicos, simplificando o raciocínio, compreende-se que dois sujeitos podem ser iguais, do ponto de vista fático, quanto à altura, ao peso, à cor do cabelo, etc., mas, ao mesmo tempo, podem ser diferentes quanto à idade, à cor dos olhos, ao gênero, etc.

Do mesmo modo, quando se avalia existir igualdade na definição de regimes normativos, sendo esta uma constatação de um observador externo ao sistema jurídico, também se trata de uma igualdade descritiva. Exemplo disso poderia ocorrer a partir da verificação de que A recebe a mesma remuneração que $B$, recolheu a mesma quantia deste a título de imposto sobre a renda, recebeu o mesmo enquadramento previdenciário, entre outros. Diante destes tratamentos normativos, é possível qualificar

\footnotetext{
${ }^{46}$ Peter Western faz a mesma observação em sua obra. Ao comentar a igualdade prescritiva, ele afirma: "It represents a relationship, not of 'is' (or not solely of 'is', but of 'ought'. It represents things, not as they are (or not solely as they are), but as they ought to be". Cf. Speaking of equality, Princeton: Princeton University Press, 1990, pp. 60-61.
} 
estas situações como relações de igualdade entre ambos, ao menos no que tange aos citados aspectos (igualdade descritiva). Distinta, porém, é a questão sobre qual o tratamento jurídico que respeita a igualdade. Nesta circunstância, tanto as semelhanças, quanto as diferenças, podem vir a ser relevantes para se definir qual o equilíbrio necessário em relação a determinada regulação normativa (igualdade prescritiva) ${ }^{47}$. Assim, características fáticas e jurídico-descritivas são analisadas para fins de se atribuir direitos e obrigações de acordo com a igualdade.

Por aí se vê há uma interação dialética entre igualdade fática e normativa. Com esta observação, não se pretende afirmar que apenas o direito de igualdade apresente esta característica, mesmo porque, sabe-se bem, a relação entre realidade e normatividade, entre ser e dever ser, concerne ao fenômeno jurídico como um todo ${ }^{48}$. $\mathrm{O}$ que se quer ressaltar, neste ponto, é que um dos maiores obstáculos para uma satisfatória cognição e aplicação do direito da igualdade encontra-se na própria tarefa de identificação das circunstâncias fáticas que influenciam na definição do regime normativo. Isto é, no que tange ao direito de igualdade, a implicação entre fato e norma é peculiar no sentido de que a aplicação do direito de igualdade deve levar em consideração as reais semelhanças e diferenças que existem entre as pessoas.

Em suma, articular as dimensões fática e normativa da igualdade é um dos grandes desafios para a jurisdição constitucional da igualdade. Com efeito, a necessidade de avaliação das circunstâncias fáticas quando da conformação do direito positivo, examinando quais semelhanças e quais diferenças são relevantes para cada tratamento normativo, bem assim qual o peso que cada uma dessas semelhanças e diferenças tem na equação da igualdade, faz desta uma norma de grande maleabilidade, porquanto variável à medida das transformações da realidade, seja pela alteração das próprias características, seja pela mudança do peso que cada característica tem na definição da relação de igualdade.

\footnotetext{
${ }^{47}$ Peter Western afirma: "the significant difference between prescriptive equality and descriptive equality lies in the nature of their underlying standards of camparison. In the case of descriptive equalities, the standards of comparison are themselves descriptive. That is to say, the standards of comparison that underlie equalities are standards for comparing people and things solely with respect to what they actually are, as opposed to how they ought to be treated". Cf. Speaking of equality, pp. 65-66.

${ }^{48}$ Formulador de uma teoria que busca relacionar dados fáticos e normativos na construção de uma teoria do direito, Friedrich Müller afirma que "direito e realidade não promovem cada um por si e de modo independente uma relação entre entidades existentes, que pode ser formulada de maneira geral, mas apresentam, numa mistura que vai se alternando, fatores atuantes na concretização do direito, dotados de uma autonomia apenas relativa". Cf. Teoria estruturante do direito, $2^{a}$ ed. São Paulo: Editora Revista dos Tribunais, 2009, p. 147.
} 
Isso quer dizer que uma mesma comparação pode sugerir diferentes relações de igualdade ao longo do tempo. Exemplo clássico disso refere-se à igualdade entre homens e mulheres, ou entre brancos e negros. Se tempos atrás as diferenças entre ambos justificavam um tratamento mais vantajoso dos homens brancos, atualmente essas mesmas contraposições (por gênero e por etnia) seguem outras lógicas, ensejando em regra regimes não discriminatórios. Ou ainda, elas fundamentam tratamentos jurídicos mais favoráveis aos grupos historicamente menos favorecidos (discriminação positiva), o que se justifica como forma de correção do tratamento privilegiado para os homens brancos de outrora.

O importante a destacar, em face do exemplo acima, é que a alternâncias das relações fáticas provocou ampla modificação do equilíbrio normativo, nada obstante a igualdade encontrar-se prevista nos mais diversos ordenamentos jurídicos há séculos. $\mathrm{O}$ que houve, enfim, foi a alteração do sentido normativo da igualdade, bem como das relações fáticas a ela subjacentes. Dentre estas, é de se destacar o peso e o valor que tais características passaram a ter na construção do direito, alterando o entendimento da igualdade à medida que evoluía a realidade cultural.

\subsubsection{Igualdade Formal $X$ Material}

A distinção entre igualdade formal e igualdade material talvez seja a mais comentada em trabalhos de direito constitucional ${ }^{49}$. Como, em geral, a aproximação do tema é feita pelo prisma histórico, costuma-se relacionar o direito de igualdade aos paradigmas políticos que marcaram a história do constitucionalismo moderno. Primeiramente, vincula-se ao liberalismo típico do final do século XVIII e começo do século XIX a ideia de igualdade meramente formal, no sentido de que sua fórmula básica (todos nascem livres e iguais em direitos) ${ }^{50}$ requer apenas a extirpação de privilégios de classe. Em um segundo momento, com o surgimento do Estado Social, ao final do século XIX e início do século XX, a igualdade passa a ter o sentido de

\footnotetext{
${ }^{49}$ Cf. José Afonso da Silva, Curso de direito constitucional positivo, $7^{\text {a }}$ ed. São Paulo: Malheiros Editores, 2007, pp. 214-215; Uadi Lammêgo Bulos, Curso de direito constitucional, pp.451-452; Regina Maria Macedo Nery Ferrari, Direito constitucional, p. 574-575. Tratando da mesma ideia, Jorge Miranda faz a contraposição entre igualdade jurídica (perante a lei) e igualdade social (na sociedade); cf. Manual de direito constitucional, tomo IV, p. 239.

${ }^{50}$ Nesse sentido, The Virginia Declaration of Rights, de 1776: "That all men are by nature equally free and independent and have certain inherent rights". Também, Déclaration des droits de l'homme et du citoyen, de 1789: "Les hommes naissent et demeurent libres et égaux en droits".
} 
igualdade material, cuja máxima poderia ser resumida à ideia de igualdade na lei, em contraponto à noção liberal de igualdade perante a lei ${ }^{51}$.

A ideia de igualdade perante a lei decorre de uma perspectiva que vislumbra na própria lei um instrumento eficaz de concretização da igualdade ${ }^{52}$. Isto é, deriva de um pensamento que entrevê na lei uma fórmula que regula condutas de modo imparcial, sem atentar para características individuais e, portanto, sem promover privilégios de classe e/ou discriminações odiosas. Tratando-se de um modelo regulatório que prima pela generalidade e pela abstração de seus termos ${ }^{53}$, a igualdade seria realizada à medida que essa mesma lei fosse aplicada sem distinções. Assim, a igualdade formal representa o imperativo de que a lei tenha uma aplicação universal e sistemática, haja vista que aplicá-la de modo diferenciado provocaria uma quebra da isonomia implícita na generalidade dos mandamentos legais.

Essa construção da igualdade formal, como dito, está alicerçada no pensamento liberal do início do constitucionalismo. Àquela época, marcada por uma divisão social em estamentos com regimes jurídicos diversos, em que prevalecia a nobreza com seus privilégios, nascia o ideário de todo ser humano tem o mesmo valor, devendo ser tratado como um igual ${ }^{54}$. Ao defenderem maior liberdade e maior igualdade, os cultores do liberalismo objetivavam desatar os grilhões do absolutismo real, bem como extirpar o tratamento privilegiado oferecido àqueles que, na visão da época, detinham poderes extraordinários fundados numa suposta natureza especial.

Como decorrência desse primeiro sentido (igualdade formal), a igualdade também é vista como uma exigência de impessoalidade por parte dos criadores e aplicadores do Direito. Trata-se aqui de uma interpretação segundo a qual as leis e suas

\footnotetext{
${ }^{51}$ Para corroborar essa ideia, muitos autores poderiam ser citados. Por todos, transcreve-se a seguinte afirmativa de José Afonso da Silva: "Nossas Constituições, desde o Império, inscreveram o princípio da igualdade, como igualdade perante a lei, enunciado que, na sua literalidade, se confunde com a mera isonomia formal, no sentido de que a lei e sua aplicação tratam a todos igualmente, sem levar em consideração as distinções de grupos. A compreensão do dispositivo vigente, nos termos do art. $5^{\circ}$, caput, não deve ser assim tão estreita. O intérprete há que aferi-lo com outras normas constitucionais, conforme apontado supra, e especialmente com as exigências da justiça social, objetivo da ordem econômica e da ordem social". Cf. Comentário contextual à Constituição, 6 ed. São Paulo, Malheiros, 2009, 72.

${ }^{52}$ Segundo Geraldo Ataliba, "a lei é instrumento da isonomia”. Cf. República e Constituição, p. 159.

${ }^{52}$ Segundo Geraldo Ataliba, "a lei é instrumento da isonomia”. Cf. República e Constituição, p. 159.

${ }^{53}$ Cf. Anacleto de Oliveira Faria, Do princípio da igualdade jurídica, São Paulo: Ed. Revista dos Tribunais, 1973, p. 27.

${ }^{54}$ Ronald Dworkin considera que a igualdade é respeitada quando todos são tratados com igual consideração e respeito. Cf. A virtude soberana, p. 574.
} 
aplicações devem ser uniformes ${ }^{55}$, sem discriminações, ou seja, produzidas com generalidade e abstração ${ }^{56}$. Nesse diapasão, entende-se que a igualdade formal exige que a lei não trate de modo distinto determinados grupos por uma suposta natureza especial e que sua aplicação não sofra alterações de acordo com o caso concreto, isto é, seja aplicada com rigidez para uns e maleabilidade para outros. A lei deve ser cumprida com igual rigor, sem levar em consideração aspectos pessoais.

Por outro lado, a igualdade material possui uma lógica oposta à igualdade formal. Enquanto esta, de certa forma, se satisfaz com o tratamento impessoal e genérico da lei, bem assim com sua aplicação pautada na indiferença em face de características pessoais dos destinatários dos comandos normativos, aquela (igualdade material) requer uma produção legislativa que leve em consideração as diferenças fáticas entre as pessoas e, ao definir as posições subjetivas no ordenamento jurídico, volte-se para a correção das desigualdades existentes na realidade.

Com frequência, afirma-se que a igualdade material representa a exigência de igualdade $n a$ lei, ou melhor, de igualdade na criação da lei e do seu conteúdo ${ }^{57}$. Por esse prisma, a igualdade não se resume a exigir uma legislação sem casuísmos e uma aplicação impessoal dos mandamentos legais, mas sim considera a igualdade um instrumento de equalização das desigualdades sociais. Ou seja, do ponto de vista da igualdade material, o direito de igualdade vai além do papel de garantir que as leis

\footnotetext{
${ }^{55}$ Nessa linha, afirma Humberto Ávila: “A igualdade formal garante a aplicação uniforme da lei: os cidadãos e os contribuintes em particular, devem ter o mesmo tipo de aplicação da lei, sem qualquer distinção". Cf. Teoria da igualdade tributária, p. 74.

${ }^{56}$ Ao tratar da igualdade perante a lei como exigência de generalidade, afirma Antonio Enrique Pérez Luño: "El principio de la igualdad ante la ley se identifica, em este plano, com los requisitos de generalidade y abstracción de la norma jurídica; esto es, com la exigência de una tipificación em términos impersonales y universales de los supuestos que han de servir de base para la atribución de determinadas consecuencias jurídicas". Cf. Dimensiones de la igualdad, p. 22.

${ }^{57}$ J. J. GOMES CANOTILHO equipara a noção de igualdade material à de igualdade na própria lei: "O princípio da igualdade, no sentido de igualdade na própria lei, é um postulado de racionalidade prática: para todos os indivíduos com as mesmas características devem prever prever-se, através da lei, iguais situações ou resultados jurídicos. (...) Reduzido a um sentido formal, o princípio da igualdade acabaria por se traduzir num simples princípio de prevalência da lei em face da jurisdição e da administração. Consequentemente, é preciso delinear os contornos do princípio da igualdade em sentido material. Cf. Direito constitucional e teoria da Constituição, p. 427. Na mesma linha, ensina Jorge Reis Novais: "Foi assim que, à medida que se foi tomando consciência das falsas expectativas sobre a justiça manente da lei geral e se foram reconhecendo os abusos cometidos sobre a justiça imanente da lei geral e se foram reconhecendo os abusos cometidos pelo próprio legislador democrático, as preocupações e anseios de igualdade - que até então se concentravam nos perigos provindos de uma aplicação inigualitária da lei foram-se transferindo para o próprio plano da criação da lei e do seu conteúdo". Cf. Os princípios constitucionais estruturantes da República portuguesa, p. 103.
} 
sejam uniformes, sem privilégios ou discriminações odiosas. A igualdade material requer, isto sim, que a lei seja elaborada tendo em vista as diferenças fáticas.

Por aí se vê que a igualdade material se volta para um exame qualitativo da igualdade na disciplina das relações sociais. Diferentemente da igualdade formal - que parte da premissa de que todos merecem ser tratados como iguais, sem distinções e privilégios de classe, chegando à conclusão de a lei não casuística é, em si, isonômica a igualdade material parte da premissa de que as pessoas, embora sejam iguais em suas condições humanas, possuem condições fáticas diversas que, muitas vezes, justificam tratamentos desiguais corretivos. Trata-se, enfim, de uma perspectiva que realça a necessidade de tratamento desigual dos desiguais, na medida de suas desigualdades, o que remete à ideia de igualdade proporcional, a ser oportunamente analisada ${ }^{58}$.

Como afirmado supra, a igualdade material é invariavelmente relacionada com os paradigmas do Estado Social, típico do final do século XIX e início do século XX. Neste período, acrescentou-se outro sentido à consagrada igualdade de viés liberal, voltada para a extirpação de privilégios e discriminações negativas. Isto é, a igualdade ganhou novos contornos, já não mais limitado à garantia de iguais oportunidades, mas sim para a transformação da sociedade ${ }^{59}$. Fenômeno representativo deste movimento é a positivação dos direitos sociais, os quais têm por objetivo oferecer bens escassos a pessoas menos favorecidas para, com isso, reduzirem a desigualdade econômica na sociedade.

Diante de todos esses fatores, é preciso ressaltar que, nada obstante as diferentes perspectivas adotadas pela igualdade formal e a material, elas não são excludentes entre si, mas apenas refletem dimensões distintas do direito de igualdade. Conforme será observado ao longo deste trabalho, ambas influenciam sobremaneira a jurisdição constitucional da igualdade, cada qual à sua maneira.

\footnotetext{
58 Tópico 1.3.3.

${ }^{59}$ Vale citar Jorge Miranda: "Sem dúvida, merece ser acolhida se se toma a primeira como mera igualdade jurídico-formal ou como igualdade liberal, inspirada numa concepção jusracionalista, e a segunda como igualdade jurídico-material, ligada a uma atitude crítica sobre a ordem social e económica existente e à consciência da necessidade e da possibilidade de a modificar (seja qual for a orientação política que se adopte. É válida ainda, enquanto se distinguem não tanto duas espécies de preceitos jurídicos quanto dois momentos ou planos: o da atribuição dos direitos em igualdade e o da fixação das incumbências do Estado e da sociedade organizada perante as condições concretas das pessoas. Os direitos são os mesmos para todos; mas, como nem todos se acham em igualdade de condições para os exercer, é preciso que essas condições sejam criadas ou recriadas através da transformação da vida e das estruturas dentro das quais as pessoas se movem". Cf. Manual de direito constitucional, tomo IV, pp. 240-241.
} 


\subsubsection{Igualdade Paritária X Proporcional}

Para além das contraposições dimensionais relativas à interação entre fatos e normas (igualdade fática $\mathrm{X}$ normativa) e à distinção entre seus fundamentos históricos (igualdade formal X material), a terceira contraposição a ser investigada diz respeito ao seu objeto de proteção. A razão disso é que o direito de igualdade pode ser utilizado tanto para agasalhar tratamentos equânimes (equiparados), quanto proporcionais. No primeiro caso, haverá a defesa de uma igualdade paritária entre sujeitos que não podem ser discriminados sem que haja uma violação à igualdade. No segundo, haverá a defesa de relações proporcionais, sejam elas de igualdade entre iguais, ou de desigualdade entre desiguais.

É certo que essa distinção guarda, em boa medida, correlação quanto ao exposto no tópico anterior, sendo a igualdade paritária uma noção correlata a de igualdade formal, e a igualdade proporcional correspondente a de igualdade material. De qualquer forma, existem peculiaridades a serem realçadas quando se compara não o fundamento histórico e a racionalidade das dimensões da igualdade, mas sim os objetivos de cada uma dessas ideias de igualdade.

Pela noção de igualdade paritária, a igualdade é sinônima de não discriminação, ou seja, de não diferenciação entre sujeitos. Tendo em vista seu fundamento liberal, já analisado, seu objetivo é determinar que o ordenamento jurídico contenha regras de liberdade individual uniformes para todos, que nascem iguais em direitos $^{60}$. Por isso afirma-se que igualdade paritária é dotada de finalidade negativa, porquanto voltada para a vedação de tratamentos jurídicos disformes ${ }^{61}$. Sua ideia, em última instância, é afastar visões políticas que considerem alguns sujeitos "melhores" e/ou "superiores" a outros, a ponto de desfrutarem de privilégios legais, ou então visões que considerem determinados sujeitos "inferiores" a outros, portanto passíveis de receber tratamentos discriminatórios, prejudiciais. De toda forma, havendo a exigência

\footnotetext{
${ }^{60}$ Sobre o assunto, sustenta José J. G. Canotilho: "A igualdade é, desde logo, a igualdade formal ('igualdade jurídica', 'igualdade liberal' estritamente postulada pelo constitucionalismo liberal: os homens nascem e permanecem livres e iguais em direitos. Por isso se considera que esta igualdade é um pressuposto para a uniformização do regime das liberdades individuais a favor de todos os sujeitos de um ordenamento jurídico". Cf. Direito constitucional e teoria da Constituição, p. 426.

${ }^{61}$ Utiliza a expressão 'negativa', dentre outros, Jorge Miranda: "O sentido primário do princípio é negativo: consiste na vedação de privilégios e de discriminações”. Cf. Manual de direito constitucional, tomo IV, p. 253.
} 
de tratamento paritário, não caberá diferenciação entre os sujeitos, que deverão ser tratados de forma equiparada.

O problema da noção assinalada supra é que, como a noção de igualdade paritária se satisfaz na generalidade e abstração das leis, bem assim na sua aplicação uniforme, desigualdades porventura arbitrárias poderiam vir encobertas pelo manto da abrangência geral da norma ${ }^{62}$. Nestas circunstâncias, a igualdade paritária não teria forças para fazer valer a igualdade dentro da lei, mesmo porque este tipo de discriminação não constitui objeto de sua proteção. Na realidade, esta finalidade escapa à sua lógica, sendo antes de tudo um escopo inerente à igualdade proporcional.

Tratando-se de igualdade proporcional, entende-se que uma relação entre dois sujeitos pode estar de acordo com a igualdade constitucional seja quando os regimes normativos a que estão sujeitos são equivalentes, seja quando são diferenciados $^{63}$. Em outras palavras, o respeito a igualdade nem sempre está vinculado a não discriminações (igualdade negativa), mas sim está relacionada com imputações igualitárias (igualdade entre iguais) e diferenciadas, desde que essa diferenciação seja proporcional às diferenças existentes entre os sujeitos (igualdade positiva) ${ }^{64}$. Em síntese, a igualdade proporcional apresenta-se de modo dinâmico e dúplice no sistema jurídico ${ }^{65}$.

\footnotetext{
${ }^{62}$ É o que destaca Jorge Reis Novais: "Mesmo quando a lei conferia os mesmos direitos e deveres a todos (o que nem sempre acontecia seja devido à concepção particular de cidadão, seja porque se discriminava em função de categorias de pessoas - os negros, as mulheres, os que professavam certa religião), a generalidade da lei não raras vezes encobria ou era ela própria fonte das maiores injustiças, já que, impedindo-se de proceder a diferenciações materiais, tratando da mesma forma aquilo que, à partida, era substancialmente diferente, a lei geral e abstracta legitimava, mantinha e aprofundava as situações de injustiça e desigualdade, deixando os mais fracos à inteira mercê da mão invisível, dos desígnios da (pouca) sorte e dos abusos dos poderosos". Cf. Os princípios constitucionais estruturantes da República portuguesa, p. 103.

${ }^{63}$ A afirmação não é novidade, como salienta Maria Glória F. P. D Garcia: "Fundado na igualdade relativa, cedo se tornou claro que o princípio da igualdade não traduz só o tratamento igual de situações iguais. Envolve ainda o tratamento diferenciado de situações objectivamente consideradas diferentes, na medida exacta da diferença”. Cf. Estudos sobre o princípio da igualdade, p. 15.

${ }^{64}$ Jorge Miranda ensina que a igualdade proporcional pode ser considerada "positiva", pois fundamenta tanto tratamento igual de situações iguais, quanto desigual de desiguais. Cf. Manual de direito constitucional, tomo IV, p. 255.

${ }^{65}$ Em descrição semelhante, sustenta Antonio Enrique Pérez Luño: "La igualdad ante la ley implica, en ocasiones, el tratamiento diferenciado de circunstancias y situaciones semejantes, pero de acuerdo con presupuestos normativos que excluyan la arbitrariedad o la discriminación. El postulado de la diferenciación evita que el principio de la igualdad ante la ley se traduzca en un uniformismo, que supondría tratar todo de la misma manera, cuando 'los supuestos de hecho que se producen en la vida son tan distintos entre sí que no permiten medirlo todo por el mismo rasero'. La exigencia de diferenciación entraña el no considerar la igualdad formal en sentido estático, sino dinámico. La igualdad no puede ser concebida, en todas las ocasiones, como una absoluta identidad de trato. En cualquier sector dela
} 
Com efeito, a citada duplicidade do direito de igualdade mostra-se relevante quando se nota que, em face de um questionamento simples e direto sobre a compatibilidade de determinada diferença de tratamento legal com a igualdade, duas espécies de resposta, diametralmente opostas, são invariavelmente aduzidas, ambas com fundamento na igualdade. Por um lado, será possível uma resposta no sentido de que a questionada diferença de tratamento normativo viola a cláusula constitucional da igualdade, simplesmente porque todos têm direito a um tratamento igual, razão pela qual se deve considerar a diferenciação como contrária à igualdade. De outro lado, não causará espanto uma resposta que, em face de idêntica situação, afirme que a diferença de tratamento não viola a igualdade, pois ela estaria tratando desigualmente sujeitos que, na realidade fática, são desiguais.

A mesma duplicidade poderia ocorrer em face de um tratamento legal uniforme entre sujeitos distintos. Uns poderiam sustentar que a unidade do regramento oferecido está conforme a igualdade, ao passo que outros poderiam argumentar que, dadas as diferenças fáticas entre os sujeitos englobados pela norma examinada, determinar o mesmo regime jurídico para ambos acarretaria na manutenção de suas diferenças, de modo a violar o direito de igualdade.

No âmbito da igualdade proporcional, ambas as posições podem estar de acordo com a igualdade. A grande questão a ser respondida não é, propriamente, se há ou não uma violação ao direito de igualdade, mas sim qual relação deve vigorar naquele contexto. Afinal, esta dubiedade (ou dinamicidade) pode ser considerada intrínseca à noção de igualdade proporcional, mostrando-se onipresente nas questões jurídicas que a ele concernem. Resolver pela correção de uma ou de outra não deve ser o objetivo do aplicador que se depare com esta situação, já que tanto equiparações quanto diferenciações são compatíveis com a ideia de igualdade proporcional.

O que importa observar, neste contexto, é que a variação das dimensões de igualdade (paritário ou proporcional) não decorre de uma diferenciação no grau de aplicação do direito de igualdade, como se para uns a igualdade devesse ser realizada em grau, ou intensidade, maior do que para outros, mas sim da concepção que se tem do papel que a igualdade constitucional deve exercer sobre o ordenamento jurídico em no pueden ser soslayadas". Cf. Dimensiones de la igualdad, p. 28. 
determinada circunstância. É dizer, as controvérsias concernentes ao direito de igualdade não devem girar em torno da afirmação, ou negação, da igualdade, mas sim sobre o sentido de igualdade que deve ser observado, se o paritário ou o proporcional e, no caso deste, se igual entre iguais ou desigual entre desiguais.

Para exemplificar, basta lembrar algumas delicadas questões relativas ao direito de igualdade, como a questão das cotas, raciais ou sociais, nas universidades públicas $^{66}$. Tanto os defensores da sua constitucionalidade, quanto os defensores da sua inconstitucionalidade, fundamentam suas posições na igualdade. Os primeiros afirmam que as quotas são um instrumento de afirmação da igualdade à medida que corrigem desigualdades fáticas, enquanto que os segundos sustentam que as quotas ferem o direito de igualdade porque se utilizam de critérios não afeitos às finalidades legitimamente buscadas pelas universidades. Por um lado, os defensores das quotas defendem a incidência da igualdade no sentido proporcional, por outro lado os que argumentam a sua inconstitucionalidade o fazem com base na igualdade em sentido paritário, ao menos com relação ao critério étnico ou social, que em suas visões ensejam discriminações arbitrárias contrárias à ideia de que todos nascem iguais em direitos.

Antes de prosseguir, é imperioso ressaltar que a controvérsia citada encontra-se presente nas discriminações positivas em geral. Destarte, praticamente todas as ações afirmativas são alvo de grandes polêmicas referentes à igualdade, justamente porque aplicam este direito com uma finalidade corretiva historicamente contextualizada, utilizando-se de critérios que, tradicionalmente, eram vedados pela noção de igualdade paritária. É o que ocorre nos favorecimentos de gênero, etnia, idade, entre outros, os quais nada mais buscam senão a concretização de uma igualdade proporcional $^{67}$.

\footnotetext{
${ }^{66}$ Esse tema foi objeto de decisão do Supremo Tribunal Federal na ADPF 186, na qual o tribunal considerou constitucional a política de cotas étnico-raciais para seleção de estudantes da Universidade de Brasília. Do mesmo modo, no RE 597285, julgou-se constitucional o sistema de cotas adotado pela Universidade Federal do Rio Grande do Sul (UFRGS).

${ }^{67}$ Acerca das discriminações positivas, ensina Manoel Gonçalves Ferreira Filho: "Tais normas seriam a resposta à discriminação contra esses grupos no passado. 'Discriminariam', de modo positivo, no sentido de que seriam a resposta a práticas e normas discriminatórias que teriam pesado contra os mencionados grupos e seriam a fonte das desvantagens de que eles hoje padecem. Justificar-se-iam em face da igualdade, por configurar um tratamento favorável que corresponderia à situação de desvantagem existente. Cf. Princípios fundamentais do direito constitucional, São Paulo: Editora Saraiva, 2009, p. 207.
} 
No fundo, a aplicação de uma ou outra dimensão da igualdade, para o mesmo caso, diz respeito à escolha dos critérios e finalidades relevantes para reger a matéria. Assim, para quem considera que o acesso às universidades deve ser regido pelo mérito estritamente acadêmico, o emprego de critérios socioculturais desnatura a relação de igualdade. Todavia, para quem considera que o papel das universidades é não apenas técnico, mas também social, outros critérios, que não o mérito acadêmico, podem ser levados em consideração ${ }^{68}$. Neste caso, a menção constitucional ao critério de seleção pela "capacidade de cada um" deve ser interpretada de forma ampla, abrangendo ideias como a capacidade de superação, ou então a capacidade deve ser aferida à luz das dificuldades sociais de cada um.

Não se pretende, aqui, solucionar estes dilemas, mesmo porque eles não são passíveis de soluções fundadas na lógica. $O$ que se pretende salientar é uma característica essencial da igualdade, qual seja, o de que ela deve ser observada, ora como uma obrigação de paridade, ora como uma obrigação de proporção. Por isso, as diferenciações de tratamento normativo, fundadas na ideia de igualdade proporcional, não são restrições ao direito de igualdade e, portanto, não devem sofrer um ônus de justificação maior do que as equiparações legais, por estarem em desacordo com a noção de igualdade paritária ${ }^{69}$. Deve-se entender que a aplicação da igualdade proporcional precisa estar justificada de modo racional e objetivo tanto quanto aplicação da igualdade paritária, motivo pelo qual não se entende correta a manifestação, tão frequente quanto irrefletida, no sentido de que o direito de igualdade consiste tão somente na vedação de discriminações arbitrárias. Como visto, a igualdade não se resume a uma exigência de paridade, salvo diferenciações justificadas. O que se deve verificar é a forma pela qual a igualdade rege a matéria, se na vertente de igualdade paritária, de igualdade proporcional de iguais ou de igualdade proporcional de desiguais.

\footnotetext{
${ }^{68}$ Sobre a escolha de critérios, sustenta Maria Isabel Garrido Gómez: "Com el fin de llevar a efecto la equiparación, se precisa uma operación relacional que consta de requisitos necessários referidos a uma relación particular o a un criterio específico. De ahí que se haga abstracción de datos que siendo diferentes no se estiman como relevantes, pues la equiparación requiere la no consideración de algunas diferencias compreendidas como irrelevantes". Cf. La igualdad en el contenido y en la aplicación de la ley, Madri: Dykinson, 2009, p. 165.

${ }^{69}$ É o que defende Robert Alexy: "Com isso, como já salientado diversas vezes, o enunciado geral de igualdade estabelece um ônus argumentativo para o tratamento desigual". Cf. Teoria dos direitos fundamentais, p. 409.
} 
Por aí se vê que a aceitação de que ambas as dimensões são compatíveis com a igualdade tem sérias implicações sobre a jurisdição constitucional deste direito, que pelas razões expostas não deve se pautar numa concepção, ainda que prima facie, de tratamento igualitário entre tudo e todos, mas sim na ideia de que, no processo de normatização de condutas, semelhanças e diferenças podem ser levadas em consideração para a atribuição de direitos e obrigações. Ao final, o que importa para a análise da igualdade é a correlação lógica entre seus elementos estruturais (sujeitos, critérios e finalidades), bem como a noção de justa proporção na atribuição de direitos e obrigações, no caso de igualdade proporcional, ou a ideia de igualdade natural originária de todos, no caso de igualdade paritária, exigências estas que serão delineadas a seguir.

\subsection{CONCEITO DE IGUALDADE}

Após a análise das propriedades normativas da igualdade e de suas dimensões, torna-se oportuno fixar um conceito de igualdade. Isso nem tanto porque uma posição deve ser escolhida, aderindo-se a alguma corrente doutrinária sobre o conceito de igualdade, mas sim porque a definição de uma ideia-guia de igualdade auxiliará no desenvolvimento posterior da pesquisa. Assim, o conceito a ser delineado a seguir é antes um instrumento de trabalho do que, propriamente, um objetivo do mesmo.

Além de exigir correlação lógica entre sujeitos, critérios e finalidades, a igualdade também requer uma igual consideração de todos os destinatários da lei, já que todos possuem ao menos uma igualdade original, qual seja, a natureza humana (igualdade paritária), assim como requer o equilíbrio na distribuição de bens, direitos e obrigações entre os sujeitos em comparação (igualdade proporcional). Isto é, além de exigir que os sujeitos e os critérios comparativos tenham pertinência lógica com finalidades legítimas, a igualdade também impõe que os tratamentos oferecidos aos sujeitos sejam uniformes, decorrentes de normas gerais e abstratas que desconsiderem hierarquias supostamente natas, e que a atribuição de regimes jurídicos seja balanceada, propiciando uma relação calibrada e proporcional na atribuição de direitos e obrigações.

A conjugação de noções estruturais e substanciais pode ser explicada pelo seguinte questionamento: de que adianta uma diferenciação estar fundada em critério 
condizente com uma finalidade se ela resultar de preconceitos ou se acarretar em regulação desequilibrada, com um dos sujeitos recebendo vantagens excessivas ou insuficientes em comparação com o outro sujeito? Igualdade, reitere-se, deve estar alicerçada também em conteúdos normativos relacionados seja com a vedação de privilégios e discriminações por razões naturais ou sociais incompatíveis com a igualdade original de todos os seres humanos, seja com a exigência de proporção na distribuição de bens, direitos e obrigações.

Conjugando-se as noções estruturais com as posições recém-expostas sobre o conteúdo normativo do direito de igualdade, chega-se à conclusão de que uma comparação entre dois sujeitos atende ao direito de igualdade quando há (i) coerência lógica na interação entre seus elementos estruturais, (ii) afastamento de discriminações preconceituosas e (ii) proporcional distribuição de direitos e deveres entre tais sujeitos. De toda a análise, deve resultar uma relação jurídica coerente, não discriminatória e equilibrada.

É certo que os aspectos estruturais e substanciais dialogam entre si, imiscuindo-se numa relação representada tão somente pelo signo da igualdade. Assim é que o elemento estrutural finalidade é relevante não apenas para verificar se há pertinência lógica no regime jurídico analisado à luz da igualdade, como também serve de norte para a identificação de discriminações arbitrárias e para a determinação do mérito de cada um e, portanto, da porção de bens, direitos e obrigações a que fazem jus. No entanto, o desmembramento é relevante à medida que atende às exigências metodológicas, estabelecendo premissas mais sólidas para o desenvolvimento do trabalho, haja vista que aparta três características da igualdade permitirão uma melhor identificação do papel da jurisdição constitucional na proteção da igualdade.

Pelo exposto, verifica-se que a presente dissertação trabalhará com a premissa de que a igualdade constitucional exige das atividades de criação e aplicação das normas uma compatibilidade com a estrutura lógica da igualdade, e com seus sentidos substanciais, quais sejam, o de que todos nascem iguais em direitos e fazem jus a uma atribuição proporcional de regimes jurídicos. Afinal, essas características não são 
excludentes entre si, mas sim denotam dimensões intrínsecas à noção de igualdade e compatíveis entre $\mathrm{si}^{70}$.

\subsection{IGUALDADE NA CONSTITUIÇÃo de 1988}

\subsubsection{Cláusula Geral}

Feita a análise das propriedades normativas do direito de igualdade, suas possíveis dimensões e seu conceito, é hora de se examinar os dispositivos constitucionais que fazem referência à igualdade, impondo seu cumprimento de forma sobranceira no ordenamento jurídico. Conforme se notará, não são poucos os enunciados constitucionais que tratam dessa temática. Caberá a esta seção tecer algumas considerações acerca desses preceitos.

Desde logo, é preciso enfatizar um dado notório: no constitucionalismo moderno $^{71}$, a igualdade se faz notavelmente presente. Prova disso é sua constante previsão nas vigentes Constituições de importantes e influentes Estados ocidentais ${ }^{72}$. No ambiente jurídico-constitucional brasileiro, a qualidade de cláusula geral de igualdade

\footnotetext{
70 Ao comentar a diferença entre isonomia formal e material, afirma José Afonso da Silva: "A Constituição procura aproximar os dois tipos de isonomia, na medida em que não se limitara ao simples enunciado da igualdade perante a lei; menciona também igualdade entre homens e mulheres e acrescenta vedações a distinção de qualquer natureza e qualquer forma de discriminação". Cf. Curso de direito constitucional positivo, p. 215. Também defende o caráter complementar das dimensões, Antonio Enrique Pérez Luño: "La conexión necesaria de la igualdad de procedimiento con los presupustos materiales sobre los que el procedimiento opera permite apuntar, como consecuencia de estas reflexiones, la continuidad entre las dimensiones formal y material de la igualdad. Ambos aspectos de este valor fundamental no pueden concebirse como compartimentos estancos, o como ideales contradictorios (tesis paralela a la que traza una fractura insalvable entre las libertades y los derechos sociales)"; cf. Dimensiones de la igualdad, p. 36. Embora trate da Constituição portuguesa, Jorge Reis Novais chega à mesma conclusão após analisar as noções de igualdade formal e material: "Pode-se dizer que a nossa Constituição acolhe expressa e eloquentemente todas estas dimensões da igualdade e procura, tanto quanto possível, determinar normativamente a solução dos problemas de igualdade inevitavelmente suscitados por facto da complexidade que o princípio adquiriu no Estado social". Cf. Os princípios constitucionais estruturantes da República portuguesa, p. 105.

${ }^{71}$ Sobre o constitucionalismo moderno, J. J. Gomes Canotilho afirma tratar-se da "teoria (ou ideologia) que ergue o princípio do governo limitado indispensável à garantia dos direitos em dimensão estruturante da organização político-social de uma comunidade". Representa, nesse sentido, "uma técnica específica de limitação do poder com fins garantísticos". Cf. Direito constitucional e teoria da Constituição, p. 51. ${ }^{72}$ No ambiente jurídico norte-americano, a Constituição garante aos cidadãos, em sua $14^{\mathrm{a}}$ emenda, a igual proteção das leis (equal protection of the laws). Na Espanha, a Constituição de 1978 garante a igualdade perante a lei em seu artigo 14. Por sua vez, a Constituição italiana de 1947 prevê o direito de igualdade em seu artigo 3. Em Portugal, a Constituição, promulgada em 1978, estabelece o assim chamado "princípio da igualdade" em seu artigo $13^{\circ}$. Na França, enfim, vige até hoje a Declaração dos direitos do Homem e do Cidadão de 1789, a qual consagra a igualdade tanto no seu artigo II, quando afirma que os homens "nascem e permanecem livres e iguais em direitos", quanto no seu artigo VI, afirmando que a lei "deve ser a mesma para todos, seja quando protege, seja quando pune".
} 
pode ser atribuída, sem maiores dificuldades, à expressão do direito de igualdade prevista no final do art. $5^{\circ}$, caput, o qual garante, aos brasileiros e aos estrangeiros residentes no País, dentre outros, a "inviolabilidade do direito à igualdade". Como se vê, trata-se de uma alusão genérica ao direito de igualdade, desprovida de complementação que indique, e delimite, quais sujeitos são iguais e em quais situações. Daí a conclusão de que ela veicula uma norma abrangente do direito de igualdade.

Do mesmo modo, a expressão "todos são iguais perante a lei, sem distinção de qualquer natureza" também pode ser considerada uma cláusula geral. A razão disso é que o preceito também é abrangente, haja vista tratar da igualdade de todos, indistintamente, sem especificar o equilíbrio normativo que pretende alcançar, ou seja, sem designar a circunstância e os sujeitos que devem ser tratados como iguais ou desiguais. Em suma, a máxima veda distinções entre as pessoas sujeitas à lei brasileira: perante a lei, todos são iguais.

A literalidade do dispositivo, bem como a sua origem histórica, indicam que a igualdade perante a lei tem a finalidade de extirpar privilégios e discriminações decorrentes da posição (ou casta) social ocupada por determinados grupos. Seu objetivo é, ao fim e ao cabo, dotar todas as pessoas de uma igualdade original (natural), fundada na condição humana ${ }^{73}$. Isso não quer dizer, porém, que não possa existir diferenças de tratamento entre as pessoas, afinal a seleção de pessoas e padrões normativos é inerente ao Direito. O que se veda, no dispositivo, é a distinção fundada numa suposta natureza superior ou inferior de alguns grupos.

Dado o significado, literal e histórico, da igualdade perante a lei, conclui-se estar ela relacionada à dimensão formal da igualdade. Assim, na esteira da contraposição, anteriormente elucidada, entre igualdade formal e material, muito se discute sobre o alcance normativo do artigo $5^{\circ}$, caput, da Constituição, isto é, se ele se limita a garantir a igualdade formal entre as pessoas, exigindo tão somente que a lei seja criada e aplicada de modo uniforme, ou se a nossa Constituição, ao prever a "igualdade de todos perante a lei”, resguardaria não apenas uma igualdade formal, dirigida aos

\footnotetext{
${ }^{73}$ Regina Maria Nery Ferrari: “naquela época, se queria acabar com os privilégios e, quando se falava que todos eram iguais perante a lei, não havia dúvida que o que se queria era impedir o tratamento mais benévolo de alguns, em virtude de serem nobres e integrantes de uma casta social por sua ascendência". Cf. Direito constitucional, São Paulo: Editora RT, 2011, p. 575.
} 
aplicadores da lei, mas também uma igualdade material, exigindo proporção da definição de regimes jurídicos (igualdade $n a$ lei).

Em geral, a doutrina entende que a cláusula geral de Constituição brasileira garante tanto a igualdade formal, quanto a igualdade material. Manoel Gonçalves Ferreira Filho, por exemplo, afirma que a igualdade prevista na Constituição consagra uma norma que se dirige ao legislador, proibindo-lhe o arbítrio e sujeitando-o à justiça $^{74}$. No mesmo sentido, Francisco Campos assevera que o destinatário da cláusula constitucional geral de igualdade é o legislador ${ }^{75}$. Por sua vez, José Afonso da Silva afirma que "essa distinção é desnecessária, porque a doutrina como a jurisprudência já firmaram, há muito, a orientação de que a igualdade perante a lei tem o sentido que, no exterior, se dá à expressão igualdade na lei, ou seja: o princípio tem como destinatários tanto o legislador como os aplicadores da lei"${ }^{, 76}$.

Para os fins deste trabalho, parte-se do pressuposto que o artigo $5^{\circ}$, caput, consagra o direito constitucional de igualdade de modo amplo e geral, estando apto a fundamentar o direito de igualdade nos seus mais diversos matizes. Isso não só pela formatação conceitual do direito de igualdade, aspecto explorado nos itens anteriores, mas também pelo fato de a igualdade estar prevista na Constituição não apenas como uma presunção natural (de que todos são iguais "perante" lei), mas também uma garantia inviolável (art. $5^{\circ}$, caput, in fine).

Examinada a cláusula geral de igualdade, o trabalho passa a focar as cláusulas constitucionais específicas.

\subsubsection{Cláusulas Específicas}

A Constituição brasileira não se resume a consagrar uma cláusula geral de igualdade. Nela há uma série de referências específicas ao direito de igualdade. Contudo, este direito nem sempre é veiculado com o termo "igualdade". Em certos

\footnotetext{
${ }^{74}$ Cf. Estado de Direito e Constituição, $4^{\text {a }}$ ed. São Paulo: Editora Saraiva, 2007, p. 27.

${ }^{75}$ Em suas palavras, "não poderá subsistir qualquer dúvida quanto ao destinatário da cláusula constitucional da igualdade perante a lei. $\mathrm{O}$ seu destinatário é, precisamente, o legislador e, em consequência, a legislação; por mais discricionários que possam ser os critérios da política legislativa, encontra no princípio da igualdade a primeira e mais fundamental de suas limitações". Cf. Direito constitucional, p. 30.

${ }^{76}$ Cf. José Afonso da Silva, Curso de direito constitucional positivo, $7^{\mathrm{a}}$ ed. São Paulo: Malheiros Editores, 2007, p. 215.
} 
momentos, o constituinte a ela se referiu com outras expressões, como a que determina o tratamento "igual", ou que veda o tratamento "desigual" ou "discriminatório". Além dessa diversidade textual, nota-se ainda a existência de distintas matérias tratadas no âmbito da igualdade. Seja entre homens e mulheres, entre Estados-membros, ou entre raças, ou contribuintes, etc., a igualdade é estabelecida em nível constitucional.

O direito de igualdade foi estabelecido de modo mais específico em relação a algumas matérias que mostraram, ao longo da história, maior sensibilidade. Nestes casos, à previsão geral do direito de igualdade o constituinte acrescentou dispositivos que delimitaram sua atuação. Foi o que ocorreu, dentre outros, com relação à igualdade de gênero. No inciso IV do artigo $3^{\circ}$, o constituinte prescreveu como objetivo fundamental da República "promover o bem de todos, sem preconceitos de origem, raça, sexo, cor, idade e quaisquer outras formas de discriminação". Já no inciso I do artigo $5^{\circ}$ está definido que "homens e mulheres são iguais em direitos e obrigações, nos termos desta Constituição". Por sua vez, o inciso XXX do artigo $7^{\circ}$, veda a "diferença de salários, de exercício de funções e de critério de admissão por motivo de sexo, idade, cor ou estado civil". Por fim, o $§ 5^{\circ}$ do artigo 226 estabelece que "os direitos e deveres referentes à sociedade conjugal são exercidos igualmente pelo homem e pela mulher”.

Outra matéria em que a igualdade foi reiteradamente garantida diz respeito aos grupos étnicos. O inciso IV do artigo $3^{\circ}$ asseverou que constitui objetivo fundamental da República "promover o bem de todos, sem preconceitos de origem, raça, sexo, cor, idade e quaisquer outras formas de discriminação" (g.n.), enquanto que o inciso XXX do artigo $7^{\circ}$ vedou a "diferença de salários, de exercício de funções e de critério de admissão por motivo de sexo, idade, cor ou estado civil". Por fim, o inciso XLII do artigo $5^{\circ}$ definiu que "a prática do racismo constitui crime inafiançável e imprescritível, sujeito à pena de reclusão, nos termos da lei”.

Os portadores de necessidades especiais também configuram um grupo expressamente protegido pelo direito constitucional de igualdade. O inciso XXXI do artigo $7^{\circ}$ preceitua "a proibição de qualquer discriminação no tocante a salário e critérios de admissão do trabalhador portador de deficiência". Já o artigo 227, §1º, inciso II, a Constituição comanda, no âmbito da proteção à criança, ao adolescente e ao jovem, "a criação de programas de prevenção e atendimento especializado para as pessoas portadoras de deficiência física, sensorial ou mental, bem como de integração 
social do adolescente e do jovem portador de deficiência, mediante o treinamento para o trabalho e a convivência, e a facilitação do acesso aos bens e serviços coletivos, com a eliminação de obstáculos arquitetônicos e de todas as formas de discriminação".

No que tange às questões sociais e regionais, a Constituição é prodigiosa em ordenar o respeito à igualdade. $\mathrm{O}$ inciso III do artigo $3^{\circ}$ acolhe, como objetivo fundamental da República, "erradicar a pobreza e a marginalização e reduzir as desigualdades sociais e regionais". O artigo 43, por sua vez, determinou que "para efeitos administrativos, a União poderá articular sua ação em um mesmo complexo geoeconômico e social, visando a seu desenvolvimento e à redução das desigualdades regionais". No âmbito orçamentário, o constituinte garantiu que "os orçamentos previstos no $\S 5^{\circ}$, I e II, deste artigo, compatibilizados com o plano plurianual, terão entre suas funções a de reduzir desigualdades inter-regionais, segundo critério populacional" (artigo 165, $\$ 7^{\circ}$ ). Enfim, consignou-se como princípio da ordem econômica "a redução das desigualdades regionais e sociais" (artigo 170, inciso VII).

Aspecto da mesma forma relevante do ponto de vista constitucional é a previsão de tratamento isonômico na esfera tributária. Consta do inciso II do artigo 150 que é vedado à União, aos Estados, ao Distrito Federal e aos Municípios “instituir tratamento desigual entre contribuintes que se encontrem em situação equivalente, proibida qualquer distinção em razão de ocupação profissional ou função por eles exercida, independentemente da denominação jurídica dos rendimentos, títulos ou direitos". Ademais, no art. $195, \S 9^{\circ}$,

O tema do acesso à saúde e à educação também recebeu destaque quanto à igualdade no texto constitucional. Isso ocorreu quando foi garantido o "acesso universal e igualitário às ações e serviços para a promoção, proteção e recuperação da saúde" (artigo 196, caput), bem como quando se previu, como princípio relativo ao ensino, a “igualdade de condições para o acesso e permanência na escola" (artigo 206, inciso I).

No âmbito da administração pública, o artigo 37, caput, estabelece que a impessoalidade é princípio da administração pública, o inciso I proclama a exigência de concurso público para investidura em cargo ou emprego público e o inciso XXI determina que a contratação com o poder público sejam precedidas por licitações, preceitos estes que se relacionam com a igualdade. Demais disso, o artigo $39, \S 1^{\circ}$, fixa 
critérios para o estabelecimento de padrões de vencimentos, aspecto este que alimenta diversas discussões judiciais sobre remuneração no serviço público ${ }^{77}$.

Diante do exposto, nota-se que a Constituição brasileira é pródiga em enunciados relativos ao direito de igualdade, não se resumindo a prever a igualdade de todos perante a lei, ou a garantir, de modo genérico, a inviolabilidade do direito à igualdade. Em temas historicamente sensíveis à igualdade, esta mereceu maior detalhamento por parte do constituinte, que delineou alguns elementos necessários para o estabelecimento de uma relação consonante com a igualdade. Isto é, em determinadas circunstâncias, o constituinte desde já explicitou os sujeitos envolvidos na relação, tratando dos critérios de equiparação/diferenciação e indicando a finalidade buscada.

Como exemplo desse raciocínio, cite-se a igualdade entre homens e mulheres, que foi estabelecida em diversos dispositivos constitucionais, além, é claro, de estar abrangida pela cláusula geral no artigo $5^{\circ}$, caput, bem como no artigo $5^{\circ}$, inciso I. Assim, nota-se que o constituinte (i) afirmou o objetivo fundamental de se promover o bem de todos "sem preconceitos de sexo" (art. 3", inc. IV), vedando a discriminação odiosa fundada neste critério de distinção; (ii) estabeleceu a proibição de diferença de salários, de exercício de funções e de critério de admissão por motivo de sexo (art. $7^{\circ}$, inc. XXX), de modo a vedar a utilização do critério de gênero em relações de trabalho e, com isso, detalhar a situação fática que visa regular, bem como a finalidade que visa atingir; (iii) definiu que "os direitos e deveres referentes à sociedade conjugal são exercidos igualmente pelo homem e pela mulher" (art. $226, \S 5^{\circ}$ ), o que derrogou a aplicabilidade de antigas normas civis que privilegiavam o poder familiar masculino em detrimento do feminino; entre outros.

Isso tudo demonstra que, tratando-se do direito de igualdade, cuja estrutura é complexa (relação de sujeitos, critérios e finalidades), a substância é fluida (referindose à não discriminação e ao equilíbrio e à justa proporção na atribuição de bens, direitos e obrigações) e a natureza regulatória é metanormativa, não é demais a especificação de alguns aspectos que indicam a relação de igualdade determinada pela Constituição. Nesse sentido, percebe-se que a repetida previsão de igualdade entre homens e mulheres, ou mesmo de outras relações específicas de igualdade, como as demais

\footnotetext{
${ }^{77}$ Conforme será analisado ao longo do trabalho, a isonomia de vencimentos é uma questão tipicamente analisada à luz da igualdade.
} 
ressaltadas neste item, não constituem redundância ou pleonasmo constitucional, mas sim complementações e detalhamentos elucidativos do equilíbrio igualitário desejado pelo constituinte. 


\section{II) Fundamentos da Tutela Judicial}

2.1. Considerações gerais; 2.2. Relação de inconstitucionalidade; 2.2.1. Relação de bipolaridade; 2.2.2. Relação tripolar; 2.3. Formas de inconstitucionalidade; 2.3.1. Inconstitucionalidade por ação ou por omissão; 2.3.2. Inconstitucionalidade total ou parcial; 2.3.3 Inconstitucionalidade explícita ou implícita; 2.4. Decisão de inconstitucionalidade; 2.4.1. Sentenças simples; 2.4.2. Sentenças manipulativas; 2.4.3. Sentença de modulação de efeitos.

\subsection{CONSIDERAÇões GERAIS}

O direito constitucional de igualdade, analisado sob o ponto de vista de sua tutela judicial, exige profunda reflexão metódica.

Por se tratar de um parâmetro constitucional abrangente, cuja força normativa pode alcançar múltiplas regulações normativas oferecidas em nível infraconstitucional, o controle de constitucionalidade que é feito em seu nome requer uma rigorosa análise do processo de identificação da relação de inconstitucionalidade, das formas pelas quais ele se manifesta e das decisões que declaram a inconstitucionalidade e reparam a afronta ao direito de igualdade.

A identificação da relação de inconstitucionalidade decorrente da violação à igualdade configura a primeira etapa da sua jurisdição. Por ela, definem-se quais as posições jurídicas que, colocadas em comparação, apresentam diferenças ou equiparações incompatíveis com o direito de igualdade. Reflete, portanto, uma fase primordial da jurisdição constitucional da igualdade, cujo principal escopo é distinguir no ordenamento os regimes jurídicos inconciliáveis com as exigências materiais da igualdade constitucional. Nesta missão, serão úteis as considerações feitas no primeiro capítulo sobre o conteúdo normativo da igualdade.

Por sua vez, a análise das formas de inconstitucionalidade importa para a assimilação das relações normativas infraconstitucionais que podem caracterizar uma 
violação ao direito constitucional de igualdade. Busca-se, aqui, averiguar se tanto atos legislativos comissivos quanto comportamentos omissivos podem revelar atitudes contrárias à igualdade constitucional. Noutro giro, investigam-se as diferenças entre a inconstitucionalidade total, em que o regime normativo é contrário ao direito de igualdade como um todo, e a inconstitucionalidade parcial, onde a inconstitucionalidade está em apenas um dos regimes. Ao final, são examinadas as inconstitucionalidades geradas por atos normativos explícitos e aquelas ocasionadas por regimes implícitos, distinção esta que tem importante repercussão na decisão de inconstitucionalidade que corrigirá a lesão ao direito de igualdade.

Por último, atenta-se para a tipologia das decisões de inconstitucionalidade proferidas no campo da jurisdição constitucional de igualdade, momento em que são analisadas e classificadas as decisões que restauram o estado de constitucionalidade exigido pelo direito de igualdade. Nesta temática, avulta o interesse especulativo pelas sentenças constitucionais em razão da formatação da igualdade como uma relação internormativa que, no mais das vezes, requer decisões que vão além da sanção de nulidade de determinado preceito positivado, ou então decisões que atenuem os efeitos desta sanção.

\subsection{RELAÇÃO DE INCONSTITUCIONALIDADE}

\subsubsection{Relação de Bipolaridade}

No sistema geral de controle de constitucionalidade, o objeto do exame judicial é a relação ${ }^{78}$ entre duas normas: aquela consagrada em nível constitucional e outra prevista em leis e demais atos normativos de nível inferior (infraconstitucional), razão pela qual ela pode ser chamada de relação de bipolaridade. Trata-se, enfim, de uma verificação de compatibilidade entre normas de níveis hierárquicos distintos, sendo a norma constitucional superior às demais e, portanto, responsável pela invalidade destas. Nestes termos, uma norma infraconstitucional A, quando questionada em face de uma norma constitucional $\mathrm{C}$, deve abrir espaço para prevalência desta, caso o intérprete

\footnotetext{
${ }^{78}$ Segundo Jorge Miranda, "constitucionalidade e inconstitucionalidade designam conceitos de relação: a relação que se estabelece entre uma coisa - a Constituição - e outra coisa - uma norma ou um acto - que lhe está ou não conforme, que com ela é ou não compatível, que cabe ou não cabe no seu sentido". Cf. Contributo para uma teoria da inconstitucionalidade, $1^{a}$ ed. Coimbra: Coimbra Editora, 2007, p. 11.
} 
conclua haver antinomia de sentidos. Tal conclusão é simples decorrência dos dogmas da supremacia e rigidez da Constituição.

Apesar da incomum nomenclatura utilizada (bipolaridade, ou então relação binária, dual, entre outros), vale observar que o vício de inconstitucionalidade conformado nos moldes da referida relação de bipolaridade nada mais representa senão a típica relação de inconstitucionalidade. Isto é, apesar de não ser muito frequente, a designação binária em nada acrescenta aos tomos já desenvolvidos sobre o controle de constitucionalidade, servindo apenas para diferenciá-lo da relação ternária típica da jurisdição constitucional da igualdade, a qual será analisada oportunamente.

Dentro dessa mesma sistemática ora designada geral, constata-se que a relação estabelecida é de bipolaridade (ou binária), haja vista que o teste de adequação se dá entre apenas dois regimes jurídicos, um constitucional e outro infraconstitucional. Isso não quer dizer que a relação bipolar só aceita a comparação hierárquica de dois preceitos, ou enunciados prescritivos, mas sim que a relação examinada tem somente dois polos, sendo que cada um deles pode resultar da conjugação de diversos dispositivos que conformam o regime jurídico em questão.

Em outras palavras, o fenômeno da constitucionalidade, ainda que binária na maior parte dos casos, não se reduz a uma atividade intelectiva superficial, de simples leitura, identificação e resolução de conflitos aparentes entre duas normas de hierarquia diferenciada. $\mathrm{Na}$ realidade, sendo o Direito um conjunto de normas com sentidos diversos e, não raro, opostos, a atividade voltada para sua interpretação e aplicação pauta-se na cognição sistemática de seus preceitos. Em outras palavras, os conteúdos normativos colocados nos polos da relação binária de constitucionalidade, para fins de verificação da compatibilidade entre ambas, nem sempre resultam de dispositivos isolados, sendo frequente a necessidade de formulação de sentidos normativos a partir de diversos enunciados prescritivos. Norma, afirmam teóricos dos mais variados matizes, é o produto da atividade interpretativa desenvolvida a partir de dispositivos legais ${ }^{79}$.

\footnotetext{
${ }^{79} \mathrm{O}$ argumento é comum na teoria do direito. Eros Grau, por exemplo, ensina o seguinte: "o que em verdade se interpreta são os textos normativos; da interpretação dos textos resultam as normas. Texto e norma não se identificam. A norma é a interpretação do texto normativo. A interpretação é, portanto, atividade que se presta a transformar textos - disposições, preceitos, enunciados - em normas" (cf. Ensaio e discurso sobre a interpretação/aplicação do direito, $3^{\mathrm{a}}$ ed. São Paulo: Malheiros Editores,
} 
É certo que determinadas normas infraconstitucionais podem vir a afrontar mais de uma norma constitucional, o que poderia levar ao entendimento de que se trata de uma relação tripolar, tetrapolar, etc. Com efeito, na prática jurisprudencial não é difícil encontrar decisões que declaram a inconstitucionalidade de preceitos normativos por violarem duas, três, quatro normas constitucionais. Nada obstante, isto não invalida o quanto afirmado, pela seguinte razão.

$\mathrm{Na}$ hipótese de um preceito ter sua constitucionalidade contestada em face de mais de um dispositivo constitucional, por exemplo, com a alegação de que foram cometidos vícios formais (processo legislativo) e materiais, ou mesmo que a norma é inconstitucional por violar diversas determinações constitucionais materiais, o que existe é uma pluralidade de relações binárias, sendo que quaisquer delas é apta a justificar a declaração de inconstitucionalidade, mesmo porque, sabe-se bem, o acordo com a Constituição deve ser total.

A bipolaridade, enfim, refere-se à estrutura da relação de constitucionalidade, que exige uma comparação entre apenas dois regimes normativos: um constitucional e um infraconstitucional. Assim, ainda que se analise, em determinada situação, diversas normas concretizadas numa lei cuja constitucionalidade é impugnada com fundamento em diversas normas constitucionais, o que se tem são várias relações bipolares examinadas numa mesma ocasião. Isto é, o que se examina é a constitucionalidade das específicas atribuições de permissões, obrigações e proibições, e não a existência de discriminações fundadas no preconceito e a existência de proporção

2005, p. 23. Ao defender uma metódica "estruturante" do direito, Friedrich Müller faz a mesma ressalva: "O direito não se apóia somente na norma verbal, nem pode ser conquistado a partir dela e com o auxílio do processo puramente lógico, assim como da subsunção obtida pela via da conclusão silogística. O direito não é idêntico ao texto literal da disposição legal; contudo, a meta da teoria normativa estruturante aqui desenvolvida não é estabelecer uma diferença essencial e ontológica entre lei e direito, no sentido da distinção entre potência e ato, entre possibilidade e realidade, entre a 'lei' como uma entidade abstrata, ahistórica ou acima da história, e um 'direito' que, por sua vez, é originalmente ontológico. O presente enfoque limita-se à investigação da teoria do direito positivo. Para ela, a disposição legal extensivamente apreendida na normatividade materialmente determinada, e não sua versão linguística é o ponto de referência da concretização" (cf. Teoria estruturante do direito, pp. 196-197. Por fim, vale consultar também a lição de Gustavo Zagrebelsky: "preliminarmente, occorre chiarire che con la formula $<$ legge $>$ si possono intendere e in effetti si intendono due cose diverse: a) da un lato, da disposizione legislativa, deliberata e emanata nei modi previsti dalle regole sulla produzione del diritto, consistente in formule linguistiche testuali; b) dall'altro, la norme espressa dalla disposizione e ricavara per mezzo dellainterpretazione, cioè la disposizione interpretata. Non si ragiona diversamente tutte le volte in cui all'atto, alla formula, all'enunciato, alla proposizione, al testo nella loro materialitá si contrapongono la statuizione, el significato, l'interpretazione, la portata normativa, ecc". CF. La giustizia costituzionale, Bologna: Il Mulino, 1988, p. 279. 
na atribuição de direitos e obrigações entre sujeitos distintos que são protegidos pelo direito constitucional de igualdade.

Consoante será examinado a seguir, a metodologia de controle de constitucionalidade pautada em relações binárias entre normas constitucionais (superiores) e normas infraconstitucionais (inferiores) não se coaduna com a jurisdição constitucional da igualdade. Uma vez que a igualdade é um conceito relacional, fundada em testes comparativos entre uma pluralidade de sujeitos, o objeto do direito constitucional de igualdade é a relação entre dois regimes normativos infraconstitucionais (relação internormativa) e a norma constitucional de igualdade, motivo pelo qual ela pode ser considerada tripolar.

\subsubsection{Relação Tripolar}

No âmbito do direito de igualdade, o vício de inconstitucionalidade costuma emergir não a partir de um exame de compatibilidade entre uma norma constitucional e uma norma infraconstitucional (relação bipolar), mas sim a partir de uma norma constitucional e dois regimes jurídicos infraconstitucionais, colocados em comparação. Neste campo, o objeto de controle não é um regime jurídico isolado, mas sim a relação entre diferentes regimes normativos infraconstitucionais, ou seja, de relações internormativas ${ }^{80}$. Considerando-se que esta relação será analisada à luz de alguma norma constitucional de igualdade, constata-se a existência de uma relação entre três regimes, daí a nomenclatura ora utilizada: relação tripolar ${ }^{81}$, triádica $^{82}$, trilateral ou triangular $^{83}$.

Graficamente, a relação descrita acima pode ser assim representada:

\footnotetext{
${ }^{80}$ Sobre o tema, ensina Markus González Beilfuss: “en el caso de las discriminaciones normativas es la propria relación internormativa la que es inconstitucional". Cf. Tribunal Constitucional y reparación de la discriminación normativa, p. 23.

${ }^{81}$ Cf. José Joaquim Gomes Canotilho, Direito constitucional e teoria da Constituição, p. 428.

${ }^{82}$ Cf. Robert Alexy, Teoria dos direitos fundamentais, p. 399.

${ }^{83}$ Nesse sentido, afirma Alfonso Celotto: "data la portata essenzialmente relazionale del concetto di eguaglianza, il controllo esercitato al riguardo dalla Corte costituzionale non opera secondo il tradizionale schema binario ("norma oggetto" e "norma parametro"), ma implica uno schema ternario, trilatero, triangolare: accanto alla norma da valutare ed al principio constituzionale di cui all'art. 3 Cost., occorre indicare la norma guiridica di raffronto, la norma 'che, usata como pietra di paragone, consenat di cogliere da $<$ rottura $>$ dell'ordinamento"”. Cf. Il controlo di eguaglianza sulle leggi in Italia, p. 4.
} 


\begin{tabular}{|c|c|}
\hline CONTROLE EM GERAL & CONTROLE DA IGUALDADE \\
\hline Norma constitucional X & Norma constitucional I \\
\hline & \\
Norma infraconstitucional Y & Norma A \\
\hline
\end{tabular}

Como não poderia ser diferente, a estrutura peculiar do direito de igualdade, analisada no primeiro capítulo, tem repercussão sobre a metodologia aplicada em sua tutela judicial. Nesse sentido, a ideia de igualdade como uma norma estruturante do sistema jurídico, cuja força normativa advém de sua aptidão para exigir coerência entre critérios e finalidades, para afastar discriminações incompatíveis com a igualdade original de todos e para impor um equilíbrio na distribuição de direitos e obrigações, acarreta na configuração de uma relação de inconstitucionalidade própria, não mais vinculada a uma relação bipolar entre uma norma constitucional e uma infraconstitucional, mas sim referida a uma relação entre normas (relação internormativa) infraconstitucionais.

Com efeito, as ações judiciais formuladas com escopo na tutela da igualdade invocam, invariavelmente, a existência de uma situação de desequilíbrio entre dois regimes normativos, seja porque eles são equivalentes onde deveriam ser desiguais, seja porque são diferentes, onde deveriam ser equiparados. É, portanto, a equiparação ou a diferenciação de dois regimes normativos que configura o objeto de questionamento, sendo que, no caso de impugnações a tratamentos diferenciados, os fundamentos podem se somar, pugnando-se tanto pela aplicação da igualdade paritária, quanto da igualdade proporcional (na vertente do tratamento igual entre iguais). Já no caso de impugnações a tratamentos equiparados, o fundamento de eventual inconstitucionalidade será a 
exigência de tratamento desigual entre desiguais (igualdade proporcional). De qualquer forma, o objetivo é o mesmo: afastar o desconcerto de uma relação entre normas.

Assim, tanto nas demandas judiciais voltadas para a ampliação de direitos, como nos processos ajuizados para se obter a redução de obrigações, o que se contesta não é a atribuição do regime jurídico em si, mas sim a desconformidade em face de um terceiro regime normativo, que serve de parâmetro para comparação. A lógica é esta: pleiteia-se a equiparação ou a diferenciação de um determinado regime jurídico com fundamento em um terceiro regime, também chamado tertium comparationis $^{84}$. Em regra, o regime utilizado como comparação é mais vantajoso em relação ao regime jurídico a que se submete o autor da demanda judicial, seja por prever um direito de modo mais amplo, seja por estabelecer uma obrigação menos rigorosa.

Como exceção à regra de que o tertium comparationis é mais vantajoso, é de se ressaltar que existem situações nas quais a proteção judicial não é buscada com o intuito de se obter maior vantagem por parte daqueles que levam a juízo a suposta violação ao direito de igualdade. Vale dizer, há hipóteses em que se objetiva, apenas e tão somente, a extirpação de um privilégio considerado injusto por criar benefício contrário à igualdade, seja por ser excessivo, seja por ser desvinculado de uma finalidade legítima. Exemplo disso são ações judiciais que impugnam foros privilegiados $^{85}$, isenções tributárias ${ }^{86}$, prisão especial $^{87}$, etc.

\footnotetext{
${ }^{84} \mathrm{Cf}$. Alfonso Celotto, Il controlo di eguaglianza sulle leggi in Italia, p. 4.

${ }^{85}$ Neste tema, são particulares e exemplificativas as decisões do Supremo Tribunal Federal quanto aos limites do foro por prerrogativa por função. Em acórdão proferido no Inquérito 687-4/MG AgRg o tribunal reputou inconstitucional a aplicação do foro por prerrogativa de função a ex-ocupantes de cargos públicos e a ex-titulares de mandatos eletivos. Do mesmo modo, são elucidativas as decisões do Supremo Tribunal Federal relativas à igualdade das partes no processo. Sobre o tema, o tribunal já decidiu, na Ação Direita de Inconstitucionalidade $\mathrm{n}^{\circ} 1.753-2 / \mathrm{DF}$, que é inconstitucional a ampliação do prazo de decadência da ação rescisória de dois para cinco anos quando proposta pelo Poder Público (União, Estados, Distrito Federal, Municípios e suas autarquias e fundações públicas), justamente por configurar privilégio contrário à igualdade.

${ }^{86}$ Podem ser citados casos em que foram julgadas inconstitucionais isenções fiscais atribuídas a sujeitos específicos, sem qualquer razão que justificasse um tratamento especial. Na Ação Direta de Inconstitucionalidade $\mathrm{n}^{\circ}$ 3.334, por exemplo, o Supremo Tribunal Federal declarou a inconstitucionalidade do artigo 240 da lei complementar 165/1999 do Estado do Rio Grande do Norte, que havia concedido isenção de custas e emolumentos aos membros e servidores do poder judiciário. Em sua fundamentação, o tribunal afirmou que "a Constituição consagra o tratamento isonômico a contribuintes que se encontrem na mesma situação, vedando qualquer distinção em razão de ocupação profissional ou função por eles exercida (art. 150, II, CF)". No Recurso Extraordinário 236.881/RS, sobre tema semelhante, o tribunal julgou inconstitucional a isenção do imposto de renda incidente sobre a verba de representação de Magistrados, autorizada pelo Decreto-lei 2.019/83.

${ }^{87}$ Frequentemente são contestados os regimes prisionais diferenciados para determinadas autoridades. Embora o Supremo Tribunal Federal tenha considerado constitucional o tratamento mais benéfico
} 
Outro aspecto a ser elucidado é o de que a tripolaridade ínsita à relação de inconstitucionalidade no âmbito do direito de igualdade não se forma, necessariamente, a partir de dispositivos claramente isolados. $\mathrm{Na}$ verdade, a análise das relações triádicas típicas da jurisdição constitucional da igualdade exige, comumente, uma atividade interpretativa sistemática, que vai além do simples isolamento de três dispositivos a serem relacionados: um dispositivo constitucional e dois dispositivos infraconstitucionais. Pelo contrário, o delineamento da relação triádica deve ser feito a partir da identificação de regimes normativos conformadores de certas vantagens ou desvantagens, sendo que tais regimes podem ser construídos a partir de diversas proposições jurídicas $^{88}$.

Por fim, cabe avaliar uma hipótese específica em que a tripolaridade não se mostra com tanta clareza. É o caso de pleitos judiciais voltados para a diferenciação de regimes jurídico uniformes, em que os sujeitos a serem comparados à luz da igualdade encontram-se, na verdade, submetidos ao mesmo regime jurídico, razão pela qual requerem, justamente, uma diferenciação proporcional que leve em conta suas desigualdades fáticas. Nestas circunstâncias, a tripolaridade aduzida parece não estar presente. Mas está, não no plano do ordenamento, e sim no plano da questão judicial. Em outras palavras, a tripolaridade não está explícita no ordenamento, mas é alvo de avaliação, ainda que ideal, por parte do julgador. Por essas razões, o citado tertium comparationis resultaria do próprio pleito judicial, constituindo o objeto da demanda, qual seja, a criação de um novo regime jurídico.

\subsection{FORMAS DE INCONSTITUCIONALIDADE}

\subsubsection{Inconstitucionalidade por Ação ou por Omissão}

Muito se discute se as violações à igualdade decorrem de atos comissivos ou comportamentos omissivos do legislador. Neste prisma, inquieta saber se as diferenças e

oferecido aos advogados ( $\operatorname{Rcl} 4713$ / SC), o mesmo tribunal já julgou inconstitucional a definição legal de prisão especial para membro de Parlamento de Estado estrangeiro (PPE 315 AgR / AU).

${ }^{88}$ Ao tratar da importância do contexto da lei para a verificação do seu significado, afirma Karl Larenz: "uma lei é constituída, como vimos anteriormente (cap. II, 2), as mas das vezes, por proposições jurídicas incompletas - a saber: aclaratórias, restritivas e remissivas -, que só conjuntamente com outras normas se complementam numa norma jurídica completa ou se associam numa regulação. $O$ sentido de cada proposição jurídica só se infere, as mais das vezes, quando se a considera como parte da regulação a que pertence". Cf. Metodologia da ciência do direito, 6ª ed. Lisboa: Fundação Calouste Gulbenkian, 2012, p. 457. 
equiparações contrárias à igualdade devem ser controladas pela perspectiva da inconstitucionalidade por ação ou da inconstitucionalidade por omissão. Como se sabe, a depender do enquadramento que se dê à questão, alocando-a sob o instituto da inconstitucionalidade por ação ou por omissão, modifica-se substancialmente a abordagem do tema.

Destacou-se, no item anterior, que o vício de igualdade se manifesta preponderantemente em relações tripolares cujos vértices são dominados pelos regimes normativos infraconstitucionais em comparação, bem como pela norma constitucional de igualdade. Uma vez definidas as normas que compõem essa estrutura, cabe ao intérprete avaliar se essa relação possui correlação lógica, se ela parte do pressuposto de igualdade inata de todos e se ela segue um proporcional equilíbrio na atribuição de direitos e obrigações, ou seja, se a relação entre os regimes jurídicos está de acordo com a igualdade determinada em nível constitucional.

A inconstitucionalidade nas relações internormativas por violação à igualdade pode resultar tanto da atribuição de um mesmo regime jurídico para sujeitos que devem receber tratamento diferenciado, quanto do estabelecimento de tratamentos jurídicos diferenciados para sujeitos que merecem tratamento equânime. Por esta razão, cabe ao julgador verificar se o tratamento diferenciado está ou não de acordo com o direito constitucional de igualdade, ou então se a equiparação existente fere ou não o direito constitucional de igualdade. O que está em jogo, afinal, é a diferença e/ou a equiparação.

Quando o legislador garante um direito ao sujeito X, mas não a Y, ou então determina uma obrigação a $\mathrm{X}$, e não a $\mathrm{Y}$, pode-se dizer que há uma diferença de tratamento entre ambos. Do mesmo modo, se o direito ou a obrigação de um tem maior alcance que do outro, há diferença. Diante dessas situações, reivindicada a aplicação da igualdade paritária entre ambos, ou mesmo da igualdade proporcional na vertente da igualdade de iguais, surge a questão: afinal de contas, essas diferenças decorrem de ações ou omissões do legislador? Ao atribuir um direito a $\mathrm{X}$ e não a $\mathrm{Y}$, existe uma inconstitucionalidade por $a c ̧ a ̃ o$, tendo em vista que tal direito só poderia ser consolidado caso abrangesse também a Y, de modo a evitar a consagração de um privilégio inconstitucional? ou se trata de uma inconstitucionalidade por omissão, porquanto deveria existir a mesma previsão para Y, por imposição constitucional, mas esta norma 
não existe? ou ainda, o que existe é uma omissão parcial, decorrente do fato de que o direito assegurado não tem o alcance que deveria possuir?

Como definir a natureza dessa diferença e, portanto, a forma pela qual se manifesta a inconstitucionalidade, é a razão de ser deste tópico. Vale lembrar, porém, que os mesmos questionamentos podem ser feitos quando se trata do questionamento de uma equiparação em face da igualdade proporcional. Assim, diante da aplicação de um regime normativo uniforme entre sujeitos que se julgam diferentes, pode-se questionar

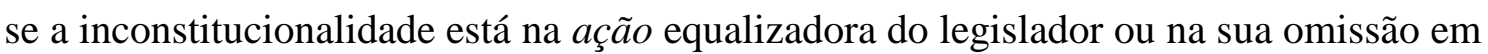
não definir regimes distintos para os sujeitos desiguais.

Atualmente, a abordagem mais frequente do tema da igualdade em nível de controle de constitucionalidade é feita no âmbito de estudos sobre a inconstitucionalidade por omissão, usualmente em subcapítulos sobre as omissões relativas (ou parciais) ${ }^{89}$.

Em termos singelos, omissão inconstitucional pode ser definida como a ausência de providência legislativa reclamada pela Constituição ${ }^{90}$. Configura-se nos casos em que, apesar da Constituição requerer a edição de norma necessária à efetivação de um mandamento constitucional, o órgão legislativo mantém-se inerte ${ }^{91}$. Decorre, portanto, do descumprimento da Constituição "por uma atitude negativa dos que são incumbidos constitucionalmente para atuar e agir" 92, distinguindo-se da inconstitucionalidade por ação, que se traduz na prática de um ato jurídico que infringe a Constituição ${ }^{93}$.

\footnotetext{
${ }^{89}$ Cf. Elival da Silva Ramos, Controle de constitucionalidade no Brasil: perspectivas de evolução, pp. 304-323; Clèmerson Merlin Clève, A fiscalização abstrata da constitucionalidade no direito brasileiro, pp. 350-36; Gilmar Ferreira Mendes, Inocêncio Mártires Coelho, Paulo Gustavo Gonet Branco, Curso de direito constitucional, $4^{\mathrm{a}}$ ed. São Paulo: Saraiva, 2009, pp. 1240-1243; José Joaquim Gomes Canotilho, Direito constitucional e teoria da constituição, pp. 1035-1036.

${ }^{90}$ Segundo Merlin Cleve, "não é apenas a ação do Estado que pode ofender a Constituição. Deveras, a inércia do Poder Público e o silêncio legislativo igualmente podem conduzir a uma modalidade específica de ilegitimidade definida, pelo direito contemporâneo, como inconstitucionalidade por omissão". Cf. A fiscalização abstrata da constitucionalidade no direito brasileiro, p. 51.

${ }^{91}$ Cf. Luís Roberto Barroso, Controle de constitucionalidade no direito brasileiro, $4^{\mathrm{a}}$ ed. São Paulo: Saraiva, 2009, p.

${ }_{92}$ Cf. Zeno Veloso, Controle jurisdicional de constitucionalidade, $2^{\mathrm{a}}$ ed. Belo Horizonte: Del Rey, 2000, p. 247.

${ }^{93} \mathrm{O}$ autor português Jorge Miranda ensina: "a inconstitucionalidade por acção é a inconstitucionalidade positiva, a que se traduz na prática de acto jurídico-público que, por qualquer dos seus elementos, infringe a Constituição. A inconstitucionalidade por omissão é a inconstitucionalidade negativa, a que resulta da inércia ou do silêncio de qualquer órgão do poder, o qual deixa de praticar em certo tempo o acto exigido
} 
Sob o prisma da inconstitucionalidade por omissão parcial, a jurisdição constitucional da igualdade é comumente estudada a partir de casos em que a inconstitucionalidade é enquadrada como um agir defeituoso, insuficiente, incompleto, decorrente de atos normativos que atendem apenas parcialmente ou de modo insuficiente os ditames constitucionais ${ }^{94}$, daí as expressões omissão parcial ou relativa ${ }^{95}$. Em outras palavras, considera-se relativa a omissão que, deixando de abranger determinado conjunto de destinatários, restringe, exclui ou discrimina um segmento de destinatários que, em razão da cláusula constitucional da igualdade, merecia o mesmo tratamento ${ }^{96}$. Por esta perspectiva, a violação da igualdade geralmente identificada como o oferecimento de tratamentos normativos diferenciados para sujeitos dignos de um tratamento equiparado - estaria na ausência de tratamento igualmente vantajoso para um sujeito que, apesar de igual (em sentido estrito), estaria sendo tratado de modo menos benéfico. $\mathrm{O}$ vício, portanto, estaria no insuficiente alcance do regime normativo comparativamente inferior.

Assim, utilizando-se da ferramenta gráfica da igualdade, teríamos a seguinte situação:

(Vantagem)

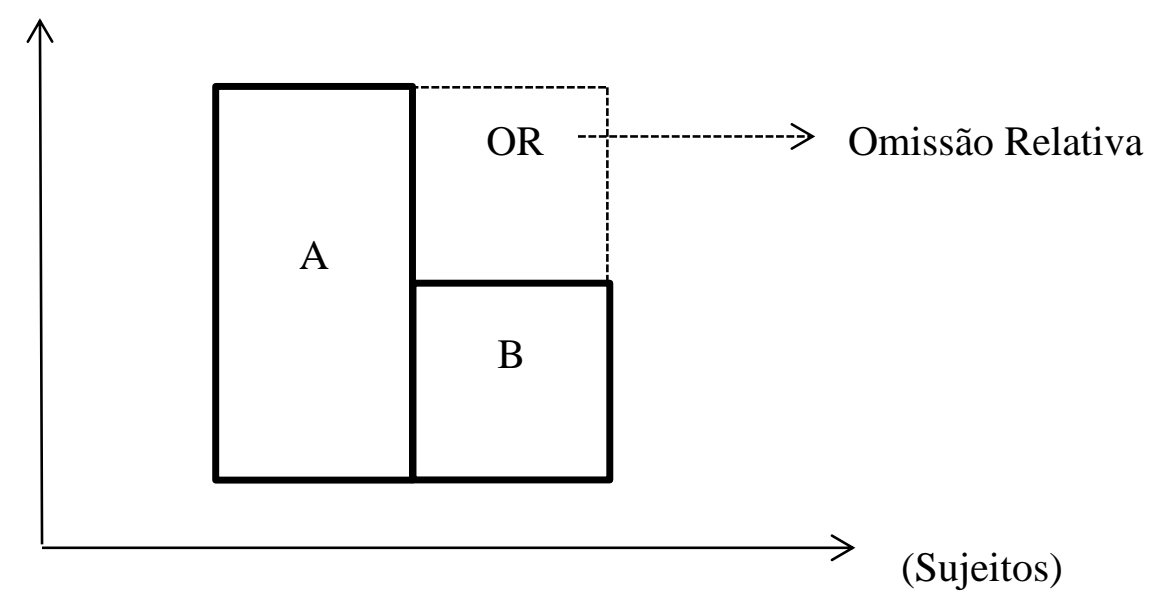

$\mathrm{Na}$ ilustração gráfica supra, fica evidente que, sob o prisma das omissões relativas, a inconstitucionalidade estaria no espaço em branco (OR) que diferencia o regime B quando em comparação ao regime A. Este, pela perspectiva representada,

pela Constituição". Cf. Manual de direito constitucional, tomo VI, $3^{\text {a }}$ ed. Coimbra: Coimbra Editora, 2008 , p. 35

${ }^{94}$ Cf. Gilmar Ferreira Mendes, Inocêncio Mártires Coelho e Paulo Gustavo Gonet Branco, Curso de direito constitucional, p. 1076.

${ }_{95}$ Cf. José Joaquim Gomes Canotilho, Direito constitucional e teoria da constituição, p. 1035.

${ }^{96} \mathrm{Cf}$. Jorge Pereira da Silva, Dever de legislar e proteção jurisdicional contra omissões legislativas, Lisboa: Universidade Católica Editora, 2003, p. 90. 
receberia mais direitos, ou menos obrigações (mais vantagens, enfim), que o sujeito B, o que lhe garantiria uma situação normativa mais vantajosa.

Embora seja discutível qual a melhor forma de se restabelecer a igualdade se estendendo o alcance do regime $\mathrm{B}$ ou se reduzindo o alcance do regime $\mathrm{A}$-, é inafastável a cogitação de que, na perspectiva da inconstitucionalidade por omissão, a única forma de se restaurar a igualdade seria ampliando o alcance do regime $\mathrm{B}$, equiparando-o ao regime A. Isso por uma questão lógica: restaurar a igualdade violada por uma omissão requer, inevitavelmente, o suprimento dessa omissão. A partir dessa constatação, surgiriam questionamentos sobre a forma pela qual essa colmatagem deveria ser feita. A resposta, a priori, seria de simples submissão do problema às técnicas de supressão das omissões inconstitucionais, ou seja, às nuances relativas às hipóteses de aplicação, efeitos e funcionalidade dos instrumentos de controle das omissões inconstitucionais: ação direta de inconstitucionalidade por omissão e mandado de injunção. Com isso, o estudo da jurisdição constitucional da igualdade se tornaria, de fato, um mero subcapítulo da temática geral da inconstitucionalidade por omissão.

Porém, nem sempre será essa a via mais adequada de análise do controle de constitucionalidade com parâmetro na igualdade.

Em primeiro lugar, é relevante o discernimento de que as violações à igualdade constitucional não se resumem a omissões relativas, é dizer, nem sempre a inconstitucionalidade está nos vazios normativos que existem entre dois sujeitos ou regimes normativos que, de acordo com a Constituição, deveriam receber tratamento igual (em sentido estrito). Por vezes, a inconstitucionalidade estará naquilo em que o regime $\mathrm{A}$ excede o regime $\mathrm{B}$, ou seja, estará no plus de $\mathrm{A}$, e não no minus de $\mathrm{B}$. Basicamente, é esse o fenômeno que existe quando há um privilégio inconstitucional. Em outros momentos, a inconstitucionalidade estará tanto no alcance normativo de A, quanto no alcance normativo de B. Isso pode ocorrer quando dois sujeitos ou regimes que originalmente eram tratados de modo equiparado passam a ser tratados de um novo modo, e este novo regime diferencia A e B de uma forma inconstitucional. Por último, é possível citar a hipótese de um tratamento normativo uniforme entre dois sujeitos que mereciam tratamento diferenciado, na medida de suas desigualdades.

Em suma, o que essas hipóteses demonstram é que as violações à igualdade constitucional nem sempre se resumem à insuficiência de um determinado regime 
normativo. Assim, desde logo deve ser rejeitada uma aproximação do tema que vislumbre a inconstitucionalidade, sempre, no alcance reduzido de um regime específico. Como dito, nos casos em que a igualdade constitucional requer o tratamento equiparado, a inconstitucionalidade poderá resultar de outras causas além de um desfalque na atribuição de vantagens normativas. Por isso, nem sempre será preciso estender um regime inferior para respeitar o direito constitucional da igualdade. Em muitos casos, haverá respeito à Constituição se o alcance de A for menor, ou se ambos forem maiores ou menores, desde que tenham o mesmo patamar.

Ademais, é preciso ressaltar que, mesmo nas hipóteses em que se constate, como causa da inconstitucionalidade, a insuficiência de um regime normativo, não necessariamente haverá uma inconstitucionalidade por omissão relativa. Consoante se tem demonstrado ao longo deste trabalho, violações à igualdade constitucional concretizam-se em relações internormativas, sendo que o objeto de controle não deve ser, ao menos diretamente, cada um dos regimes postos em comparação, mas sim a diferença ou a equiparação existente. Assim, o que pode vir a ser declarado inconstitucional é, justamente, a diferença ou a equivalência de regimes, circunstâncias estas que, nalgumas ocasiões, podem ser consideradas decorrências de ações legislativas discriminatórias ou desproporcionais, ainda que por insuficiência, e não de omissões legislativas.

Em síntese, violações à igualdade constitucional podem vir a ser decorrências de atos positivos, ainda que as lesões derivem da insuficiência na atribuição de direitos. Isto é, mesmo quando se trate de uma violação à igualdade resultante de uma insuficiência normativa, a inconstitucionalidade poderá estar não na omissão do legislador, mas sim na sua ação discriminatória ou desequilibrada que resultou na atribuição de direitos para uns sem a mesma abrangência para outros, que mereciam o mesmo tratamento. A inconstitucionalidade, enfim, estará no ato de limitar a abrangência de determinado direito ou obrigação a um grupo de sujeitos, de modo a excluir um segmento que, em razão do direito de igualdade, deveria ter sido incluído, mas não foi. 
O entendimento exposto, embora já estivesse presente no pensamento de Constantino Mortati ${ }^{97}$, tem encontrado amplo respaldo em recentes escritos sobre o tema. Autores como Carlos Blanco de Morais ${ }^{98}$, Sofia Montelobo ${ }^{99}$, Taciana Xavier ${ }^{100}$, Rui Medeiros ${ }^{101}$ entre outros, têm destacado essa qualificação dos regimes normativos que perfazem o objeto da jurisdição constitucional da igualdade.

No que tange aos demais formatos de violações à igualdade constitucional, a questão da natureza do ato lesivo sequer se coloca em termos de inconstitucionalidade por ação ou por omissão, prevalecendo o entendimento de que a afronta ao direito de igualdade é causada por ações legislativas. Exemplo disso é a violação decorrente de um privilégio injustificado, em que se observa uma patente ação legislativa contrária ao direito de igualdade. Do mesmo modo, atos normativos expressamente excludentes são considerados ações, e não omissões. Inconstitucionalidades particulares neste sentido são aquelas derivadas não de lacunas normativas, mas sim de regras expressas de exclusão e/ou exceção.

Por tudo isso, conclui-se que a abordagem do tema pode se dar tanto no âmbito da inconstitucionalidade por ação, quanto no da inconstitucionalidade por omissão parcial. Nesse sentido, o fenômeno da inconstitucionalidade por insuficiência no qual a violação está no fato de se um sujeito receber um tratamento menos vantajoso que outro digno do mesmo tratamento - nem sempre será estudado e analisado pelo prisma da inconstitucionalidade por omissão relativa, podendo eventualmente ser apreciado no da inconstitucionalidade por ação excludente.

\footnotetext{
${ }^{97}$ Augusto Martin de la Vega, em estudo sobre as sentenças constitucionais na Itália, avalia que "la conceptualización de la omisión como norma negativa encontrará un amplio eco en la doctrina, y así autores como Lavagna, Duni o Lanzillo, que no coinciden con las consecuencias que Mortati deriva de las sentencias aditivas, sí parten en cambio del mismo supuesto estructural: la Corte, al controlar la omisión, actúa en realidad sobre una implícita norma impeditiva”. Cf. La sentencia constitucional em Italia, Madrid: Centro de Estudios Políticos y Constitucionales, 2003, p. 240.

${ }^{98}$ Cf. Justiça constitucional, tomo II, Coimbra: Coimbra Editora, 2005, p. 460.

${ }^{99} \mathrm{Cf}$. "A tutela das omissões relativas geradas pela violação do princípio da igualdade através do controlo de constitucionalidade por acção". In: Carlos Blanco de Morais (coord.), As sentenças intermédias da justiça constitucional, Lisboa: AAFDL, 2009.

100 “A tutela das omissões relativas (geradas pela violação do princípio da igualdade) através do controle de constitucionalidade por ação, no sistema jurídico brasileiro". In: As sentenças intermédias da justiça constitucional, 2009.

${ }^{101}$ Cf. A decisão de inconstitucionalidade: os autores, o conteúdo e os efeitos da decisão de inconstitucionalidade da lei. Lisboa: Universidade Católica Editora, 1999. pp. 518-522.
} 


\subsubsection{Inconstitucionalidade Total ou Parcial}

O fenômeno da inconstitucionalidade por violação ao direito de igualdade abarca não só inconstitucionalidades totais, mas também inconstitucionalidades parciais. A distinção entre ambos é auto evidente: a primeira diz respeito à incompatibilidade completa de regimes jurídicos, ao passo que a segunda corresponde à incompatibilidade de apenas uma parcela destes. No que concerne à jurisdição da igualdade, essa distinção será importante para fins de verificação da extensão do vício de inconstitucionalidade ${ }^{102}$.

Do exposto infere-se, desde logo, que a inconstitucionalidade representa, no atual estágio do constitucionalismo brasileiro, sanção que admite o parcelamento dos atos normativos ${ }^{103}$, seja este fracionamento relativo ao aspecto formal (incisos, alíneas e parágrafos de uma determinada lei), seja relativo ao aspecto material (significado normativo) ${ }^{104}$. No que tange à jurisdição da igualdade, toma relevo a inconstitucionalidade parcial no sentido material, como será demonstrado.

O direito de igualdade, como tem sido observado, pode ser violado seja pela positivação de dois regimes jurídicos de mesmo alcance para sujeitos que deveriam ser tratados desigualmente, seja pela regulação diferenciada imposta a sujeitos que mereciam tratamento equiparado. A questão que se coloca, quando se trata de analisar a forma da inconstitucionalidade, é se a lesão ao direito de igualdade foi causada por

\footnotetext{
${ }^{102}$ Sobre o assunto, afirma Marcelo Neves: "A inconstitucionalidade total significa a pertinência inválida, por nulidade ou anulabilidade conforme o sistema, de toda uma norma legal específica ao ordenamento jurídico. A inconstitucionalidade parcial implica a pertinência inválida, por nulidade ou anulabilidade, de apenas uma parte de determinada norma legal". Cf. Teoria da inconstitucionalidade das leis, São Paulo: Saraiva, 1988, p. 121. Também Elival da Silva Ramos: "Por outro prisma, pode-se classificar a inconstitucionalidade em total ou parcial, de acordo com a extensão do vício no tocante ao conjunto normativo do diploma legal"; cf. A inconstitucionalidade das leis, p. 163. No mesmo sentido, cf. Oswaldo Luiz Palu, Controle de constitucionalidade: conceitos, sistemas e efeitos, p. 75.

${ }^{103}$ No mesmo sentido, afirma Clèmerson Merlin Clève: "a inconstitucionalidade será total ou parcial conforme esteja a contaminar todo o ato ou a incidir apenas sobre parcela dele. Da distinção é possível deduzir a regra da parcelaridade dos atos normativos. Ou seja, os atos normativos, para efeito de fiscalização de constitucionalidade, podem sofrer parcelamento. Assim, não deverá ser declarada a inconstitucionalidade total de uma lei (no sentido material ou formal) caso apenas parte dela esteja tomada por vício ou vícios propiciadores de ilegitimidade constitucional. Neste caso, a decisão cassatória do órgão fiscalizador incidirá apenas sobre a parcela maculada do ato normativo". Cf. A fiscalização abstrata da constitucionalidade no direito brasileiro, p. 48 .

${ }^{104}$ Elival da Silva Ramos: "essa inconstitucionalidade parcial, por outro lado, desdobra-se em várias espécies: há, por assim dizer, uma inconstitucionalidade parcial quantitativa, que se reporta ao ato normativo em sua expressão formal, contaminando alguns de seus dispositivos (artigos, incisos, parágrafos, etc.) ou meramente sentenças ou até mesmo simples expressões deles constantes; e uma inconstitucionalidade parcial qualitativa, que, reportando-se ao conteúdo (norma) de um ou mais dispositivos do ato questionado, fulmina variantes interpretativas a eles vinculadas". Cf. Controle de constitucionalidade no Brasil, p. 264.
} 
complexo normativo em seu todo, ao positivar dois regimes jurídicos infraconstitucionais que incorreram no nivelamento de desiguais ou na diferenciação de iguais, ou se a violação decorreu do fato de um dos regimes em comparação ter ido além do que podia, ou ter ficado aquém do que devia. Na primeira situação, haverá uma inconstitucionalidade total. $\mathrm{Na}$ segunda, uma inconstitucionalidade parcial, seja ela decorrente de uma ação legislativa que tenha reduzido ou afastado parte de um regime jurídico, ou mesmo de uma omissão legislativa que seja responsável por uma lacuna parcial no ordenamento.

Diferentemente da inconstitucionalidade parcial, a ser examinada adiante, a inconstitucionalidade total apresenta-se como uma modalidade abrangente, porquanto se refere a uma relação internormativa tal como positivada pelo legislador, ou seja, em todo o seu âmbito. Nesse sentido, não abre margem a uma investigação parcial, acerca do alcance normativo de somente um dos regimes jurídicos infraconstitucionais. Nesse sentido, a constatação de uma inconstitucionalidade total tende a culminar numa operação ablativa pura: declara-se a nulidade do complexo normativo como um todo, eliminando-o do ordenamento jurídico.

Embora o fenômeno da inconstitucionalidade total não esgote a matéria, ele também não é descartável. Este é um ponto relevante, que indica não apenas a complexidade da questão, justamente por envolver tipos distintos de inconstitucionalidade, como também denota que o tema pode, em grande medida, ser analisado pelo "tradicional" prisma da sanção de nulidade total dos preceitos normativos.

Imagine-se que duas categorias sejam historicamente tratadas de modo uniforme e que uma inovação legislativa crie dois regimes distintos para cada uma das categorias, sendo que ambas passem a ser regidas por uma nova forma. Suponha-se, ademais, que a diferenciação seja inconstitucional por configurar uma relação incoerente, ou então discriminatória, ou ainda desproporcional. Nestas circunstâncias, a inconstitucionalidade seria total ou parcial? Ao menos um caso da jurisprudência do Supremo Tribunal Federal demonstra que, numa situação como esta, a inconstitucionalidade pode estar em ambos os regimes, caracterizando o que ora se descreve como inconstitucionalidade total. Trata-se da distinção feita entre aposentados 
e pensionistas da União e dos Estados no que tange à imunidade de contribuições. Explique-se.

Em 19 de dezembro de 2003, foi promulgada a Emenda Constitucional $\mathrm{n}^{\circ}$ 41, cujo artigo $4^{\circ}$ previu a incidência de contribuição previdenciária nos benefícios percebidos pelos servidores inativos e pensionistas da União, Estados, Distrito Federal e dos Municípios. Tal regra inovou o sistema de custeio da seguridade social, pois antes as contribuições sociais incidiam tão-somente nas remunerações dos servidores ativos. Em seu parágrafo único, a emenda definiu a base de cálculo de tais contribuições, diferenciando-a entre os aposentados e pensionistas dos Estados, Distrito Federal e Municípios, de um lado, e os da União, de outro. Tal emenda teve sua constitucionalidade contestada, sob várias perspectivas e argumentos, perante $\mathrm{o}$ Supremo Tribunal Federal. Entretanto, no que tange à discriminação perpetrada entre os servidores da União e os servidores dos demais entes federativos, importa ressaltar a impugnação feita na ação direta de inconstitucionalidade $n^{\circ} 3.105-8$, a qual sustentou, dentre outros, a inconstitucionalidade da emenda sob o argumento de ofensa à igualdade constitucional, em especial à isonomia tributária (artigo 150, inciso II, da Constituição Federal).

A fórmula encontrada pelo Supremo Tribunal Federal foi a seguinte: ao considerar arbitrárias as distinções previstas entre os servidores da União e os dos demais entes federativos quanto ao percentual imune às contribuições, o Tribunal declarou inconstitucionais as expressões "cinquenta por cento do" e "sessenta por cento do", constantes do parágrafo único, incisos I e II do artigo $4^{\circ}$ da Emenda Constitucional $n^{\circ}$ 41. Com isto, deveria voltar a incidir a imunidade tributária prevista no artigo 195, II, da Constituição Federal, que, como limite negativo latente no ordenamento constitucional, passaria a ter eficácia plena.

Houve, portanto, verdadeira desconstrução tanto do novo regime normativo aplicável aos aposentados e pensionistas da União (regime mais favorável, com imunidade de $60 \%$ dos rendimentos), quanto do regime menos favorável aplicável aos contribuintes inativos dos Estados, Distrito Federal e Municípios (regime menos favorável, com imunidade de 50\% dos rendimentos). Por conseguinte, definiu o tribunal que ambos se submetiam ao regime geral de imunidades geral aplicável ao servidor público, previsto no art. $40, \S 18^{\circ}$, da Constituição. 
Tal decisão foi decorrência, como se observou, da constatação de uma inconstitucionalidade total. Isso porque o tribunal não se limitou a impor a nulidade de um dos regimes, mas sim definiu que ambos são inconstitucionais.

Porém, como já se destacou supra, uma violação à igualdade também pode configurar uma inconstitucionalidade parcial, à medida que sua invalidade esteja alicerçada no seu alcance diminuto, ou superlativo, de um dos regimes infraconstitucionais examinados à luz da igualdade.

A razão pela qual a inconstitucionalidade parcial ganha especial relevo no estudo da jurisdição constitucional da igualdade guarda relação direta com as dimensões normativas da igualdade, que denotam um potencial de atuação desta como proibição de discriminações de cunho preconceituoso e como vetor de equilíbrio na atribuição de direitos e obrigações. De fato, as violações à igualdade constitucional surgem não apenas de conteúdos normativos isolados, que conferem direitos ou definem obrigações inteiramente inválidas. Comumente, a inconstitucionalidade decorre do excesso, ou da insuficiência, do alcance normativo dado a determinado regime jurídico.

Como visto anteriormente, a inconstitucionalidade parcial por insuficiência tem sido tratada, em regra, à luz do fenômeno da inconstitucionalidade por omissão. Mais especificamente, como uma inconstitucionalidade por omissão relativa (também chamada parcial). Destarte, no mais das vezes doutrina e jurisprudência reconhecem no minus normativo uma situação de omissão do legislador, que deveria ter positivado um regime jurídico de maior alcance. Ocorre que, conforme já avaliado, eventualmente a insuficiência pode decorre não de um silêncio parcial do legislador, mas sim de um comportamento parcialmente excludente.

Por outro lado, ao passo que a insuficiência pode ser reflexo de uma inconstitucionalidade parcial por ação ou por omissão, o excesso configura uma inconstitucionalidade parcial derivada de um ato normativo, e não de uma ausência normativa. Neste caso, o alcance normativo é excedente no sentido de que, se fosse até certo ponto seria constitucional, mas transpassando tal limite incide em inconstitucionalidade, na medida do excesso.

Em suma, um regime normativo é parcialmente inconstitucional por violar a igualdade quando oferece mais, ou menos, do que deveria. É o caso, por exemplo, de 
normas que venham a determinar reajustes salariais distintos para categorias que, em tese, fazem jus a um tratamento equiparado. Suponha-se que uma categoria A tenha recebido um reajuste de $10 \%$, enquanto que uma categoria B tenha ganhado um reajuste de $5 \%$, sendo que a elas se aplica a igualdade aritmética no que tange ao regime salarial. Nesta circunstância, seria possível vislumbrar uma inconstitucionalidade parcial tanto por excesso no reajuste de A (5\% maior do que deveria), quanto por insuficiência no reajuste de B (5\% menor do que deveria).

Um exemplo concreto que se enquadra no raciocínio desenvolvido supra é a diferenciação feita entre servidores civis e militares da União quanto ao reajuste de remuneração feito em 1995, diferenciação esta que gerou uma inconstitucionalidade parcial. Tal situação fica clara quando se analisa o RMS 22.307-7/DF ${ }^{105}$. No acórdão proferido neste processo, afirmou-se que a previsão de reajuste de $28,86 \%$ ofertado apenas para os servidores militares, com o afastamento dos servidores civis, fere o princípio da isonomia, motivo pelo qual o reajuste deveria abranger também a categoria dos servidores civis.

Outro exemplo a ser citado pode ser encontrado na ADI $3.854 \mathrm{MC} / \mathrm{DF}^{106}$. Esta teve por objeto a impugnação de resoluções do CNJ que definiram tetos remuneratórios diferenciados para os membros da magistratura estadual e federal, de modo a submeter somente os primeiros ao teto do subsídio mensal dos desembargadores do respectivo Tribunal de Justiça. Em sua decisão liminar, o tribunal reconheceu uma distinção arbitrária, haja vista o caráter nacional do poder judiciário. Destarte, julgou inconstitucional o tratamento menos benéfico dos magistrados estaduais, que deveriam ser submetidos ao mesmo teto da magistratura federal, que era comparativamente mais vantajoso.

Os exemplos acima demonstram com precisão aquilo que vem sendo chamado de inconstitucionalidade parcial no seu sentido material. Afinal, eles denotam inconstitucionalidades não de todo o complexo normativo examinado, mas sim de apenas um dos regimes postos em comparação pelo teste da igualdade. Assim, eventual constatação de inconstitucionalidade por estas razões não levaria à sanção de nulidade

\footnotetext{
${ }^{105}$ RMS 22307/DF; Relator(a): Min. MARCO AURÉLIO; Julgamento: 19/02/1997; Órgão Julgador: Tribunal Pleno.

${ }^{106}$ DI 3854 MC / DF; Relator(a): Min. CEZAR PELUSO; Julgamento: 28/02/2007; Órgão Julgador: Tribunal Pleno.
} 
de ambos os regimes, mas sim à sanção de nulidade de apenas um dos regimes normativos.

Por aqui já se percebe que o tema da inconstitucionalidade parcial é delicado e merece aprofundamento, haja vista o poder de conformação normativa que requer do órgão que realiza o controle de constitucionalidade com parâmetro na igualdade, o qual está jungido a limitações funcionais e processuais que exigem cautela na tarefa de proteger citado direito. Esta análise, contudo, será retomada mais adiante. Por ora, convém prosseguir na questão das formas de inconstitucionalidade típicas da igualdade.

\subsubsection{Inconstitucionalidade Explícita ou Implícita}

Dentre as formas pelas quais se manifestam as lesões à igualdade constitucional, uma questão digna de nota concerne à aparência destas violações. Nessa esteira, é relevante discernir se as violações surgem de modo explícito ou de modo implícito na legislação infraconstitucional. Como a própria denominação indica, a forma explícita decorre das expressas e aparentes violações à igualdade, ao passo que as implícitas decorrem de afrontas imanentes e recônditas, as quais somente podem ser constatadas a partir de uma interpretação sistemática e histórica do ordenamento jurídico.

Desde já, é preciso ressaltar que essa distinção entre inconstitucionalidade explícita e implícita não se coaduna com a distinção usualmente feita com base nessa nomenclatura. Com efeito, costuma-se utilizar tais expressões para significar a separação entre inconstitucionalidades decorrentes de normas constitucionais explícitas ou implícitas ${ }^{107}$. Para os fins deste trabalho, contudo, a distinção entre inconstitucionalidade explícita e implícita concerne às normas infraconstitucionais, mesmo porque as normas constitucionais que definem o direito de igualdade estão expressamente consagradas na Constituição brasileira de 1988, como já foi demonstrado

\footnotetext{
${ }^{107}$ É o que fazem, por exemplo, Marcelo Neves (Teoria da inconstitucionalidade das leis, pp. 124-126) e Clèmerson Merlin Clève (A fiscalização abstrata da constitucionalidade no direito brasileiro, p. 56).
} 
anteriormente $^{108}$. Enfim, implícito ou explícito não são, aqui, qualidades do parâmetro, mas sim do objeto de controle.

Em geral, as inconstitucionalidades explícitas ocorrem nas ocasiões em que os regimes jurídicos incompatíveis com a Constituição apresentam-se como discriminações expressas, textualmente isoladas ${ }^{109}$. Essa situação fica evidente quando o legislador cria diferenças entre sujeitos que, anteriormente, eram tratados da mesma forma, de acordo com os ditames da igualdade paritária, ou da igualdade proporcional no viés da igualdade entre iguais. Por outro lado, também será explícita a inconstitucionalidade quando o legislador uniformiza o regime legal de sujeitos que eram tratados de forma desigual, em proporção às suas diferenças. Essas alterações legislativas, expressas que são, assinalam uma forma explícita de violação, na qual é possível identificar e separar os dispositivos legais que causaram, aberta e diretamente, a contrariedade ao direito de igualdade.

Do mesmo modo, será explícita a inconstitucionalidade nos casos de omissão parcial em que o legislador positiva regime jurídico sem atentar aos mandamentos constitucionais em sua completude. Assim, embora resultado de lacuna, as omissões parciais poderão ser consideradas explícitas à medida que a Constituição determine, expressamente, uma abrangência que não é seguida pelo legislador. Exemplo dessa situação é o citado caso dos reajustes de remuneração dos servidores civis e militares. Neste caso, a Constituição era expressa no sentido de que não deveria haver distinção de índices entre servidores públicos civis e militares. Ainda assim, o legislador reajustou apenas o índice referente aos servidores militares, omitindo-se parcialmente quanto aos servidores civis. Aqui, houve uma inconstitucionalidade explícita por omissão parcial.

Em síntese, se uma legislação exclui (ação) ou deixa de incluir (omissão) um determinado grupo da abrangência de um direito, ou então lhe reduz a amplitude deste, vislumbra-se uma discriminação explícita. O mesmo pode ocorrer se o legislador

\footnotetext{
108 Tópico 1.5 .

${ }^{109}$ No mesmo sentido, afirma Markus González Beilfuss: “el segundo gran tipo de discriminación es el de la diferenciación expresa, es decir, el de los supuestos en que los regímenes jurídicos objeto de comparación son aislables. Esta categoría engloba tanto a los casos en que dichos regímenes jurídicos se encuentran en preceptos separados, como a los casos en que la discriminación deriva de un único precepto que excluye o diferencia a un determinado colectivo a través de uno o varios incisos aislables. Se trata, pues, de una categoría más amplia y heterogénea que la de la discriminación por exclusión tácita, pero que en todo caso se caracteriza por el carácter expreso y aislable de la diferenciación". Cf. Tribunal constitucional y reparación de la discriminación normativa, pp. 30-31.
} 
seleciona um determinado subgrupo anteriormente regido por uma norma abrangente e lhe atribui um regime explicitamente mais vantajoso ou prejudicial.

Exemplo concreto de exclusão explícita por ação pode ser encontrado na ADPF 1.351/DF ${ }^{110}$, que tratou da chamada cláusula de desempenho. A citada ação direta teve por objeto a declaração de inconstitucionalidade de dispositivos da Lei $n^{\circ}$ 9.096/95 que determinavam, diante da gradação de votos obtidos por partidos políticos, o afastamento do funcionamento parlamentar, a redução substancial do tempo de propaganda partidária gratuita e a diminuição da participação no rateio do Fundo Partidário daqueles partidos que não cumprissem alguns requisitos mínimos. Tratava-se de ação excludente explícita entre partidos, feita com base no critério da representatividade congressual dos mesmos. Isso porque os partidos que não atingissem patamares mínimos de votação, estabelecidos no artigo 13 da referida lei, estariam sujeitos às reduções aduzidas.

Por unanimidade, o Supremo Tribunal Federal julgou procedente a ação direta e declarou a inconstitucionalidade dos dispositivos que estabeleciam a diferenciação entre os partidos políticos, bem como das consequências previstas para aqueles que não atingissem o patamar mínimo de representatividade. Ao sancionar de nulidade o regime excludente que se instaurava, o tribunal fez prevalecer o regime provisório anterior, situação que foi expressamente declarada pelo tribunal. A inconstitucionalidade, enfim, estava explícita no regime legislativo, expressa em seus enunciados prescritivos.

As inconstitucionalidades implícitas, por sua vez, dizem respeito às equiparações-diferenciações que não decorrem de preceitos isoláveis, mas sim de construções interpretativas que, ao compararem regimes jurídicos positivados de forma independente, identificam afrontas ao direito de igualdade. Em outras palavras, a violação implícita não se verifica por uma expressa exclusão, ou inclusão, mas sim por uma aproximação de dois regimes jurídicos que, embora não se relacionem diretamente, podem ser comparados a título de igualdade pelo intérprete e aplicador do direito.

Como dito, as violações implícitas à igualdade constitucional somente podem ser identificadas através de interpretações sistemáticas que, ao realizarem a

110 ADI 1351 / DF - DISTRITO FEDERAL; Relator(a): Min. MARCO AURÉLIO; Julgamento: 07/12/2006; Órgão Julgador: Tribunal Pleno. 
comparação entre regimes e sujeitos distintos, constatam equiparações-diferenciações que ferem o direito constitucional de igualdade ${ }^{111}$.

A inconstitucionalidade implícita pode vir consagrada, por exemplo, quando seja aplicado um regime tributário especial que autorize determinados sujeitos passivos a recolher tributos de modo simplificado, quando tal regime não se pauta numa política de igualdade fiscal, mas sim no incremento da arrecadação em determinado setor. Do mesmo modo, a inconstitucionalidade implícita pode resultar de uma restrição às propriedades localizadas em determinado perímetro geográfico que possua características ambientais que requeiram proteção, sem que a mesma restrição seja feita em outras localidades com as mesmas características ambientais, situação em que a definição não esteja fundada numa política de igualdade entre proprietários de terras, mas sim na específica proteção daquela área.

Em termos concretos, um caso da jurisprudência do Supremo Tribunal Federal pode ser considerado exemplo de inconstitucionalidade implícita. Trata-se do julgado na ADPF 132/RJ e na ADI 24.277/DF, ações que resultaram na equiparação de casais homossexuais e heterossexuais quanto ao regime jurídico de união estável. Nestes processos, o Supremo Tribunal Federal declarou a impossibilidade de o sexo constituir fator de diferenciação jurídica, razão pela qual o artigo 1.723 do Código Civil deveria ser interpretado no sentido de excluir do dispositivo qualquer significado que impeça o reconhecimento da união contínua, pública e duradoura entre pessoas do mesmo sexo como família.

A razão pela qual a inconstitucionalidade declarada nos casos acima pode ser considerada implícita decorre do fato de que a impossibilidade de união estável entre homossexuais não foi alvo de uma exclusão explícita do legislador, no sentido de afastar um regime anterior, ou então de positivar normas jurídicas explicitamente incompletas (omissão parcial). Na verdade, o código civil havia seguido tradicional interpretação da Constituição no sentido de regrar uniões estáveis apenas para casais de homens e mulheres. Por isso, a declaração da inconstitucionalidade foi resultado de uma

\footnotetext{
${ }^{111}$ Markus Gonzáles Beilfuss refere-se a este tipo de inconstitucionalidade como discriminações por exclusão tácita, as quais "se producen cuando un régimen jurídico excluye de su ámbito de aplicación a un supuesto de hecho equivalente al regulado en el mismo, sin que dicha exclusión se produzca a través de un inciso aislable, es decir, que pueda ser suprimido sin dejar sin sentido o sin alterar profundamente el régimen jurídico en cuestión". Cf. Tribunal constitucional y reparación de la discriminación normativa, p. 30 .
} 
interpretação sistemática que comparou duas formatações distintas de casais que não havia sido alvo de aberta e expressa diferenciação.

Um aspecto que influencia na identificação da inconstitucionalidade implícita diz respeito à intenção e à consciência do legislador no que concerne às afrontas ao direito de igualdade. É certo que este sinal é de difícil identificação e, não raro, resume-se a meras suposições feitas pelos críticos do trabalho legislativo. De qualquer maneira, existem indícios que podem auxiliar na verificação deste quesito, como é o caso das exposições de motivos e dos debates congressuais, os quais consagram o método da interpretação histórica, que não pode ser desprezada ${ }^{112}$.

Ademais, com base na intenção do legislador, é possível afirmar que, enquanto na forma explícita a equiparação-diferenciação constitui objeto de deliberação específica e consolida-se de modo inequívoco na legislação, na forma implícita ela não resulta bem delineada e, embora seja possível sustentar uma indireta intenção legislativa, ela não se mostra aparente no resultado dos trabalhos legislativos, ou seja, não acarreta numa expressa exclusão ou inclusão. Simplesmente, apresenta-se como o resultado de uma seleção de padrões típica do processo de normatização de $\operatorname{condutas}^{113}$.

Disso tudo se infere que a violação à igualdade constitucional, quando não veiculada por preceitos que, deliberada e explicitamente, excluem sujeitos que mereciam tratamento equivalente, ou incluem sujeitos que mereciam tratamento diferenciado, haverá uma inconstitucionalidade implícita no ordenamento jurídico. Como será visto adiante, este formato de inconstitucionalidade enseja a prolação de

\footnotetext{
${ }^{112}$ Sobre o papel do legislador histórico, afirma Karl Larenz: "Com isto chegamos ao elemento 'histórico' da interpretação, o qual, como expusemos ao princípio, há-de ter-se em conta, também, ao averiguar do sentido da lei normativamente determinante. Sobretudo a intenção reguladora do legislador e as decisões valorativas por ele encontradas para alcançar manifestamente esse desiderato continuam a ser arrimo obrigatório para o juiz, mesmo quando acomoda a lei - por via da interpretação teleológica ou do desenvolvimento do Direito - a novas circunstâncias, não previstas pelo legislador, ou quando a complementa. Aqui surge, abertamente e de imediato, a questão de saber de que pessoas se trata, quando perguntamos pela vontade ou pela ideia normativa 'do legislador"'. Cf. Metodologia da ciência do direito, p. 463.

${ }^{113}$ Embora Joaquim José Gomes Canotilho faça uma aproximação um pouco diferente do assunto, denominando inconstitucionalidade por ação aquilo que, neste trabalho, é denominado inconstitucionalidade explícita, é possível afirmar que a intenção também é levada em consideração para se distinguir normas explícitas e implícitas. Em suas palavras: "Esta concretização incompleta tanto pode resultar de uma intenção deliberada do legislador em conceder vantagens só a certos grupos ou contemplar certas situações (exclusão expressa ou explícita), violando o princípio da igualdade e cometendo uma inconstitucionalidade por ação, como derivar apenas de uma incompleta apreciação das situações de facto, mas sem que haja o propósito de arbitrária e unilateralmente se favorecerem só certos grupos ou situações (incompletude regulativa)". Cf. Direito constitucional e teoria da Constituição, p. 1036.
} 
tipos decisórios especiais, bem assim requer uma zelosa análise de sua competência reparatória.

\subsection{DECISÃO DE INCONSTITUCIONALIDADE}

\subsubsection{Quadro geral}

Basicamente, são três as espécies de decisões que podem ser produzidas quando o poder judiciário se depara com inconstitucionalidades decorrentes do desacordo com a igualdade. Em certas circunstâncias, uma simples sentença que declare a nulidade de uma norma específica será apta a restabelecer a igualdade que havia sido atingida. Em outras situações, uma declaração de nulidade não será hábil, por si só, a restabelecer o estado de igualdade, mas sim implicará em nova situação de infringência a este direito, motivo pelo qual somente a reconstrução dos regimes jurídicos proporcionará a devida restauração da igualdade. Por último, existem casos em que a sentença judicial não terá, de forma alguma, o condão de corrigir a inconstitucionalidade, sendo necessária decisão que suspenda os efeitos da sanção de nulidade para que o poder legislativo produza novo texto normativo que torne a situação compatível com a Constituição. Os três tipos são aqui designados como sentenças simples, sentenças manipulativas e sentença de modulação de efeitos, respectivamente.

O motivo de um capítulo sobre a tipologia das decisões de inconstitucionalidade remete ao fato de que, na jurisdição constitucional da igualdade, são frequentes as sentenças que ficam entre a declaração de procedência e a de improcedência das ações, podendo assim ser consideradas intermédias ${ }^{114}$. Por essa razão, as características descritas a seguir serão importantes para o posterior desenvolvimento e análise crítica dos modelos de reparação da igualdade.

\footnotetext{
${ }^{114}$ Consoante observa Carlos Blanco de Morais, a denominação se justifica "porque se configurariam com opção intercalar entre as variantes 'extremas' da declaração simples de acolhimento e a decisão simples de rejeição"; cf. "As sentenças com efeitos aditivos", in: As sentenças intermédias da justiça constitucional, p. 17. Também utiliza a expressão J. J. Gomes Canotilho (cf. Direito constitucional e teoria da Constituição, p. 1018.
} 


\subsubsection{Sentenças Simples}

Inicialmente, é de se firmar que, por sentença simples deve-se entender toda decisão judicial que declara a inconstitucionalidade de um dispositivo legal, imputandolhe, pura e simplesmente, a sanção de nulidade desde o seu nascimento (supressão retroativa dos efeitos produzidos) ${ }^{115}$. Não vai, portanto, além do reconhecimento de uma antinomia e aplicação do critério hierárquico, de modo a afastar a aplicabilidade do preceito inferior, por invalidade ${ }^{116}$.

A importância dessa definição decorre do surgimento de diversos tipos decisórios que fogem dessa resolução aqui qualificada como simples. Seja pela introdução de espécies decisórias moduladoras da eficácia temporal da sanção, seja pela admissão de sentenças que exterminam interpretações ou aplicações específicas (sentenças de nulidade parcial sem redução de texto), ou ainda pela elaboração de sentenças que vão além da mera eliminação de dispositivos legais impugnados, tratando também de reconstruir o sistema normativo à luz da Constituição (sentenças de efeitos aditivos), entende-se que, atualmente, as sentenças que se limitam à tradicional função de eliminar (fulminando de nulidade) dispositivos textuais específicos podem ser chamadas de sentenças simples ${ }^{117}$.

Nesse sentido, é possível afirmar que, dentre os variados tipos de decisões proferidas em sede de jurisdição constitucional, avultam as sentenças simples como aquelas que seguem o modelo norte-americano puro de judicial review, cuja principal característica é de considerar atos contrários à Constituição como necessariamente nulos

\footnotetext{
${ }^{115}$ Carlos Blanco de Morais define sentenças simples da seguinte forma: "assumem natureza simples as decisões que implicam a eliminação de uma norma inconstitucional, bem como a supressão retroactiva de todos os efeitos por ela produzidos, salvaguardados os casos julgados". Cf. "As sentenças com efeitos aditivos", in: Carlos Blanco de Morais (coord.), As sentenças intermédias da justiça constitucional, Lisboa: AAFDL, 2009, p. 15.

${ }^{116}$ Este o raciocínio que fundamentou, desde o início, o controle judicial de constitucionalidade das leis. Com efeito, já no século XVIII afirmava Hamilton: "Entretanto, se o conflito ocorrer entre atos de autoridades de hierarquia diferente, a lógica e a natureza das coisas indicam que deve ser observada regra diferente, devendo o ato anterior da autoridade mais hierarquizada ter preferência sobre o subsequente da subordinada; em consequência, sempre que uma lei ordinária contrariar a Constituição, é dever dos tribunais obedecer o prescrito por esta e ignorar aquela". Cf. O federalista, $3^{a}$ ed. Campinas: Russel Editores, 2009, p. 480.

${ }^{117}$ Essa distinção entre as sentenças simples e os demais tipos é feita pelo supracitado autor português Carlos Blanco de Morais: "as decisões de inconstitucionalidade em fiscalização abstrata sucessiva podem, atento o critério dos respectivos efeitos, desdobrar-se em duas categorias: a das sentenças simples e a das sentenças manipulativas". Cf. Sentenças com efeitos aditivos, p. 15.
} 
e írritos, portanto incapazes de produzir quaisquer efeitos ${ }^{118}$. Afinal, na lógica histórica vislumbrada nos primeiros precedentes da Corte Suprema, bem assim dos escritos doutrinários da época, o descumprimento de limites traçados por Constituições escritas e rígidas devem culminar, irremediavelmente, na invalidade do ato declarado inconstitucional $^{119}$, constituindo a nulidade uma sanção incontornável.

No âmbito da jurisdição constitucional da igualdade, de natureza eminentemente tripolar, há casos em que as sentenças de simples declaração de inconstitucionalidade (com sanção de nulidade) são incapazes de restaurar o estado de constitucionalidade. Frequentemente, as lesões à igualdade exigem a reconstrução do sistema normativo, seja com atividade integrativa do órgão judicial, seja com a positivação de novos regimes jurídicos pelo legislador. No entanto, essa não é uma regra invariável, pois existem hipóteses em que sentenças simples são perfeitamente hábeis a restaurar o estado de constitucionalidade. É o que ocorre quando a inconstitucionalidade é provocada, diretamente, pela introdução de um regime normativo específico que, por si só, gera uma violação explícita à igualdade constitucional.

Imagine-se que dois sujeitos, A e B, recebam determinado tratamento normativo compatível com a igualdade, seja pela equivalência de direitos e obrigações (igualdade paritária ou igualdade proporcional de iguais), seja pela diferença proporcional às suas desigualdades (igualdade proporcional de desiguais), nada havendo a ser reparado. Suponha-se que, a despeito dessa normatização equilibrada, sobrevenha inovação legislativa que, expressa e intencionalmente, promova uma inconstitucional diferenciação dos sujeitos A e B, justamente na esfera em que mereciam tratamento equivalente. Nestas circunstâncias, tratando-se da positivação de enunciado prescritivo que, explicitamente, viola a igualdade, e que efetua uma restrição de direitos ou uma criação de privilégios inconstitucional, deve-se concluir que uma sentença de simples

\footnotetext{
118 Ao comentar o sistema norte-americano de jurisdição constitucional, afirmou Rui Barbosa: “a invalidade da ação dos poderes políticos fora do círculo dos textos constitucionais é o dogma cardeal do constitucionalismo americano. A evolução lógica desse dogma foi traçada admiravelmente por Marshall, o supremo expositor da Constituição americana". Cf. Atos inconstitucionais, $3^{\text {a }}$ ed. Campinas: Russel Editores, 2010, p. 40.

${ }^{119}$ Em texto clássico e fundante do constitucionalismos norte-americano, Alexander Hamilton asseverou: "não há posição que se apoie em princípios mais claros que a de declarar nulo o ato de uma autoridade delegada, que não esteja afinada com as determinações de quem delegou essa autoridade. Consequentemente, não será válido qualquer ato legislativo contrário à Constituição". Cf. Alexander Hamilton, O federalista, p. 479.
} 
declaração de inconstitucionalidade do novo regime, com sanção de nulidade ex tunc, é hábil a restaurar o estado de igualdade constitucional à medida que tem condições de restaurar a eficácia dos regimes revogados.

Como exemplo, é possível citar a decisão do Supremo Tribunal Federal proferida na ADI 1.910-1/DF ${ }^{120}$, na qual o tribunal declarou inconstitucionais as medidas provisórias de n. 1.703/98 a 1.798/99, editadas e reeditadas para alterar o art. 188, I, do Código de Processo Civil, a fim de duplicar o prazo da Fazenda Pública para ajuizar ação rescisória e acrescentar o inciso X no art. 485 do Código de Processo Civil, tornando rescindíveis as indenizações fixadas em desapropriações que fossem flagrantemente excessivas ou irrisórias. Tal decisão é usualmente estudada como paradigma do controle judicial sobre o preenchimento dos pressupostos de relevância e urgência para a edição e medidas provisórias. No entanto, a decisão também carrega um importante conteúdo de igualdade, já que considerou tais medidas como contrárias à igualdade das partes no processo, pois responsáveis por criar privilégios desproporcionais. De qualquer forma, o que importa ressaltar, neste ponto, é que o tribunal proferiu uma sentença simples que eliminou as inovações legais do ordenamento, de modo a restaurar a igualdade anteriormente vigente na sistemática processual.

É certo que a igualdade poderia ter sido restaurada de outras formas, sendo uma delas a extensão dos regimes estabelecidos pela medida provisória, duplicando o prazo de ações rescisórias também para os particulares e permitindo que estes também promovessem ações revisionais de indenizações em desapropriações. Afinal, o regime anteriormente vigente não é o único de acordo com a igualdade. De qualquer forma, a decisão de inconstitucionalidade simples pode ser considerada eficiente em determinadas situações, ainda que outras hipóteses de solução sejam possíveis, conforme será oportunamente demonstrado.

Em suma, a adequação das sentenças simples está atrelada ao passado normativo que regia uma determinada relação entre sujeitos submetidos ao teste da igualdade. É dizer, se uma legislação considerada compatível com a igualdade vier a ser, total e explicitamente, alterada por uma nova legislação que, diferentemente, é

\footnotetext{
${ }^{120}$ ADI 1910 MC / DF; Relator(a): Min. SEPÚLVEDA PERTENCE; Julgamento: 22/04/2004; Órgão Julgador: Tribunal Pleno.
} 
reputada incompatível com o mesmo direito, será possível a prolação de uma sentença que, simplesmente, declare a inconstitucionalidade da nova legislação, de modo a fazer ressurgir, automaticamente, o regime jurídico revogado ${ }^{121}$.

Como a situação acima não deve ser descartada, é de se concluir que a jurisdição constitucional da igualdade pode, em grande medida, ser solucionada pelas tradicionais decisões de inconstitucionalidade, que se limitam a fulminar de nulidade a legislação inválida.

As situações que fogem ao alcance reparador das sentenças simples são examinadas a seguir.

\subsubsection{Sentenças Manipulativas}

Nos capítulos anteriores, observou-se que o controle de constitucionalidade feito em nome da igualdade tem como objeto uma relação tripolar de normas, o que o diferencia das relações de constitucionalidade gerais. Dentre as implicações que essa formatação triádica traz, está a frequente incapacidade do clássico mecanismo da nulidade dos atos normativos inconstitucionais como instrumento hábil a restaurar o estado de constitucionalidade demandado pelo direito de igualdade ${ }^{122}$. São casos em que o reconhecimento do vício de inconstitucionalidade, com a consequente eliminação do

\footnotetext{
${ }^{121}$ Vale lembrar, porém, que tal efeito não se confunde com o chamado "efeito repristinatório". Consoante ensina Elival da Silva Ramos: "diante da absoluta ineficácia da lei sancionada com nulidade, carece ela, inclusive, do efeito revogatório em relação à legislação pretérita com ela incompatível, do que adviria a 'repristinação' dos efeitos dessa legislação que se supunha revogada. Não se trata, como é fácil demonstrar, de autêntica repristinação, no sentido consagrado pelo $\S 3^{\circ}$, do art. $2^{\circ}$, da Lei de Introdução ao Código Civil brasileiro, porquanto o que se está a afirmar é que não houve revogação, em face da inconstitucionalidade da lei revogadora, razão pela qual não se deve aludir à recuperação de uma eficácia que nunca cessou. A plena aplicabilidade da legislação revogada por aquela declarada inconstitucional é solução que se impõe em todos os sistemas de controle que adotam a sanção de nulidade, estando, por exemplo, expressamente consignada no art. 282, n. 1, da Constituição portuguesa, relativamente à declaração de inconstitucionalidade com força obrigatória geral, isto é, no controle abstrato de normas". Cf. Elival da Silva Ramos, Ativismo judicial: parâmetros dogmáticos, São Paulo: Saraiva, 2010, pp. 296-297.

${ }^{122}$ Markus González Beilfuss é enfático ao ressaltar esta insuficiência. Em suas palavras: "el principio de igualdad en la ley constituye, como se acaba de señalar, el ámbito en que la crisis del modelo tradicional del legislador negativo se ha puesto más claramente de manifiesto en el caso español. Al igual que en otros países europeos, la especial estructura y contenido de dicho principio han entrado en conflicto con dicho modelo, generando unas prácticas jurisprudenciales que difícilmente pueden explicarse a partir de la caracterización del Tribunal Constitucional como legislador negativo". Cf. Tribunal Constitucional y reparación de la discriminación normativa, p. 31.
} 
preceito legal do ordenamento jurídico, não tem o condão de restabelecer, por si só, o estado de constitucionalidade.

Basicamente, a insuficiência do modelo da inconstitucionalidade-nulidade reside no fato de que, não raro, a constitucionalidade só pode ser restaurada se houver uma reconstrução da relação reputada inconstitucional. Ou seja, para além do recorte normativo que expurga o dispositivo inconstitucional do ordenamento, comumente fazse necessária uma reconfiguração dos regimes normativos questionados. Esta segunda etapa (lógica, mas não necessariamente cronológica), que reconstrói regimes jurídicos de modo a readequá-los com os parâmetros constitucionais, configura uma verdadeira manipulação do sentido normativo original, daí a denominação deste tópico: sentenças manipulativas $^{123}$.

Por sentença manipulativa deve-se entender a decisão que determina a modelação do sentido ou dos efeitos ${ }^{124}$ da norma submetida a julgamento ${ }^{125}$. Reflete, pois, um tipo decisório que vai além da simples declaração de inconstitucionalidade de um dispositivo legal, passando a modificar as normas objeto de controle. Dessa maneira, seja quando averigua sentidos ideais, declarando inconstitucional determinada aplicação da norma (nulidade parcial sem redução de texto), seja quando reconstrói as normas impugnadas, realizando uma integração do ordenamento após a eliminação de um dispositivo ou sentido ideal (sentenças de efeitos aditivos), haverá uma sentença manipulativa $^{126}$.

No que tange à chamada sentença nulidade parcial sem redução de texto e sua utilização no controle de constitucionalidade com parâmetro na igualdade, é preciso ter em mente que a contrariedade à igualdade constitucional nem sempre resta

\footnotetext{
${ }^{123}$ Augusto Martín de la Vega descreve esta evolução da jurisdição constitucional como resultado da diferenciação entre enunciado prescritivo (texto legal) e normas, a qual permitiu a manipulação de conteúdos normativos a ponto de não mais se limitar a uma redução normativa. Em suas palavras: "En buena lógica, estos pronunciamientos deberían conducir a una 'reducción' del contenido normativo de la disposición. Ahora bien, una vez admitida desde muy pronto la capacidad de la Corte para realizar 'manipulaciones' del contenido normativo recabable de la disposición, era evidente que se abría el camino para que ésta emitiera pronunciamientos del mismo tipo, pero cuyos efectos normativos no fueran de reducción sino de ampliación o modificación de dicho contenido". Cf. La sentencia constitucional en Italia, p. 221.

${ }^{124}$ A manipulação dos efeitos será tratada em tópico apartado, sob a designação de modulação de efeitos.

${ }^{125}$ Cf. Carlos Blanco de Morais, As sentenças com efeitos aditivos, p. 17.

${ }^{126}$ Elival da Silva Ramos, ao classificar os tipos decisórios da jurisdição constitucional, afirma: "as decisões de controle, ditas manipulativas em sentido amplo, podem ser subdivididas em duas categorias, seguindo-se, nesse passo, a esquematização consagrada na doutrina italiana: as sentenças interpretativas e as sentenças manipulativas em sentido estrito". Cf. Ativismo judicial, p. 211.
} 
configurada a partir de um preceito isolado e expresso, pois existe a possibilidade de que a afronta resulte de um segmento ideal da norma, ou seja, de uma interpretação específica. Neste caso, haverá uma inconstitucionalidade implícita que exigirá uma atividade jurisdicional corretiva diferenciada, não relacionada com um texto normativo, mas sim com uma aplicação sua. Nesse contexto, o órgão judicial deverá identificar uma variedade de possibilidades interpretativas para, em seguida, fulminar de nulidade apenas uma dela (ou algumas delas), mantendo, contudo, o texto positivado. Em suma, deverá eliminar o sentido incompatível com a igualdade, deixando subsistir os demais sentidos compatíveis ${ }^{127}$. Na hipótese do órgão judicial apenas fixar o sentido ideal compatível com a Constituição, a sentença realizará uma interpretação conforme a Constituição $^{128}$.

Noutro giro, tratando-se de uma inconstitucionalidade parcial qualitativa, decorrente de uma insuficiência ou de um excesso do alcance normativo, a reparação da afronta ao direito de igualdade exige uma verdadeira correção da norma impugnada, razão pela qual o órgão judicial pode vir a declarar a inconstitucionalidade do regime normativo inválido e, numa etapa lógica seguinte, definir qual o sentido que se adéqua à Constituição. Com isso, agrega-se à sentença uma declaração do sentido que deveria ter sido positivado para que a legislação restasse compatível com a Constituição. Neste caso, havendo uma atividade integrativa subsequente a uma operação ablativa, diz-se que a manipulação possui um efeito aditivo, acarretando na modalidade ora designada como sentença de efeitos aditivos, cujas características são descritas a seguir.

\footnotetext{
${ }^{127}$ Sobre esta técnica, em que se constata a inconstitucionalidade de determinada aplicação da norma, e não do seu texto normativo, ensina Lúcio Bitencourt: "Ainda no que tange à inconstitucionalidade parcial, vale considerar a situação paralela em que uma lei pode ser válida em relação a certo número de casos ou pessoas e inválida em relação a outros. É a hipótese, verbi gratia, de certos diplomas redigidos em linguagem ampla e que se consideram inaplicáveis a fatos pretéritos, embora perfeitamente válidos em relação às situações futuras. Da mesma forma, a lei que estabelecesse, entre nós, sem qualquer distinção, a obrigatoriedade do pagamento de imposto de renda, incluindo na incidência deste os proventos de qualquer natureza, seria inconstitucional no que tange à remuneração dos jornalistas e professores"; cf. O controle jurisdicional da constitucionalidade das leis, Rio de Janeiro: Forense, 1968, p. 128. Nos casos de declaração de nulidade parcial sem redução de texto, Gilmar Ferreira Mendes avalia que se considera "inconstitucional apenas determinada hipótese de aplicação da lei, sem proceder à alteração do seu programa normativo". Cf. Jurisdição constitucional, p. 345.

128 Sobre a distinção entre "nulidade parcial sem redução de texto" e "interpretação conforme a Constituição", cf. Lucas Catib De Laurentiis, Interpretação conforme a Constituição, São Paulo: Malheiros Editores, 2012, pp. 66-75.
} 
Varia na doutrina a terminologia para expressar o fenômeno aqui referenciado como efeito aditivo, ${ }^{129}$, que, como dito, nada mais representa senão as decisões de inconstitucionalidade que, além de realizarem um juízo negativo de inconstitucionalidade (componente ablativo), agregam à norma remanescente a indicação de um critério jurídico que assegure a sua compatibilização com a Constituição (componente reconstrutivo) ${ }^{130}$. Outros adjetivos, como "aditivas", “criativas", "integrativas", entre outros, são frequentemente utilizadas para expressar tal característica. Nenhum deles, porém, retrata a peculiaridade que se pretende abordar, seja por revelar uma demasiada abrangência ("manipulativas") ${ }^{131}$, ou por traduzir uma inoportuna redução ("aditivas") ${ }^{132}$, ou ainda pelo baixo índice de adesão, e portanto de maior detalhamento, na doutrina ("criativas" e "integrativas") ${ }^{133}$. Diante disso, concluise pela maior adequação da expressão efeitos aditivos, exatamente por ela traduzir um conceito de abrangência calibrada, ou seja, mais específica que o termo "manipulativas" - o que a diferencia das sentenças de nulidade parcial sem redução de texto e das sentenças de interpretação conforme à Constituição - mas, por outro lado, generosa a ponto de englobar uma variedade de subespécies decisórias, como a sentença aditiva em sentido estrito, ${ }^{134}$ a aditiva de princípio, ${ }^{135}$ a sentença substitutiva, ${ }^{136}$ a sentença

${ }^{129}$ O termo é adotado por autores como Carlos Blanco de Morais (cf. Justiça constitucional, tomo II, pp. 411 e ss.) e Markus Gonzalez Beilfuss (cf. Tribunal Constitucional y reparación de la discriminación normativa, p. 118 e ss.) e representa, ao mesmo tempo, algo maior que as sentenças aditivas em sentido estrito (modificativas), as sentenças substitutivas e outras, e também algo mais específico que as sentenças manipulativas (intermédias), que se referem a todos os tipos de sentença que vão além da mera declaração de invalidade de um texto normativo com efeito ex tunc. No caso, elas são identificadas por manipularem o sentido ou o efeito temporal das decisões e se localizarem.

${ }^{130} \mathrm{Cf}$. Carlos Blanco de Morais, Justiça constitucional, tomo II, pp. 411-412.

${ }^{131}$ Como dito, as sentenças manipulativas (também chamadas intermédias) podem ser definidas como "as decisões jurisdicionais que determinam a modelação do sentido ou dos efeitos da norma submetida a julgamento" (cf. Carlos Blanco de Morais, Justiça constitucional, tomo II, p. 261). Trata-se, portanto, de um termo de amplo significado que inclui não só as sentenças de efeitos aditivos, mas também as sentenças interpretativas e as sentenças de modulação temporal dos efeitos da decisão (cf. Carlos Blanco de MORAIS, Justiça constitucional, tomo II, p. 271; Rui Medeiros, A decisão de inconstitucionalidade, p. 457).

${ }^{132}$ Conforme se verá, as sentenças "aditivas" representam apenas uma subespécie das sentenças de efeitos aditivos.

${ }^{133}$ Tais expressões são citadas por Rui Medeiros com base da doutrina italiana. Cf. A decisão de inconstitucionalidade, p. 457.

${ }^{134}$ Em regra, quando se utiliza a expressão "sentença aditiva", é dessa espécie que se trata. Diz respeito à decisão que visa suprir omissões relativas, pois tem como sua componente reconstrutiva a declaração de que a determinada norma é inconstitucional por deixar de estabelecer determinada medida que, segundo a Constituição, deveria prever. É dela que nos fala Rui Medeiros quando se refere às sentenças modificativas, por exemplo (cf. A decisão de inconstitucionalidade, pp. 456 e ss.). Na doutrina pátria, utilizam a expressão Roger Stiefelmann Leal (O efeito vinculante na jurisdição constitucional, pp. 87 e ss.) e Elival da Silva Ramos (Ativismo judicial: parâmetros dogmáticos, p. 217).

${ }^{135}$ São as decisões que, segundo Roger Stiefelmann Leal, declaram "a inconstitucionalidade de um ato normativo até que o legislador ultime novo diploma leal que estabeleça medida exigida constitucionalmente, segundo os princípios enunciados pela Corte" (cf. O efeito vinculante na 
demolitória ${ }^{137}$ e, até mesmo, as sentenças aditivas sem redução de texto ${ }^{138}$, a qual se reaproxima da nulidade parcial sem redução de texto, embora com ela não se confunda.

Para explicar a utilidade das sentenças de efeitos aditivos na jurisdição constitucional da igualdade, é interessante, antes de tudo, ilustrar graficamente uma das formas pelas quais as relações internormativas têm sua constitucionalidade averiguada com fundamento na igualdade. Com esse recurso, será possível demonstrar a incapacidade da sanção simples de nulidade em lidar com violações à igualdade, bem assim a potencialidade reparadora das sentenças de efeitos aditivos.

Numa substancial parcela dos casos em que a violação à igualdade é suscitada, busca-se a equiparação de dois regimes normativos que possuem alcances distintos, sob o fundamento de que a igualdade, aplicada naquela circunstância, exige o mesmo tratamento. É o caso em que o sujeito demandante requer o incremento de seus direitos ou a redução de suas obrigações (ambas agregam vantagem), o que se justificaria no fato de que sujeito semelhante (igual) recebe tratamento mais benéfico. É certo que nem sempre é assim, pois existem casos em que se demandam tratamentos distintos (em nome da igualdade proporcional), assim como existem casos em que a alegada afronta ao direito constitucional da igualdade encontra-se no regime mais vantajoso atribuído a um determinado sujeito (privilégio inconstitucional). De qualquer maneira, utiliza-se do singelo exemplo acima descrito para se demonstrar a importância do estudo das sentenças de efeitos aditivos.

\footnotetext{
jurisdição constitucional, cit., p. 89). Consoante Carlos Blanco de Morais, trata-se de um tipo de decisão: “i)que pressupõe a eliminação, em regra parcial, de uma norma inconstitucional; ii) que enuncia os limites da operação reparadora de uma omissão relativa ou de uma lacuna técnica; iii) mas que se abstém de proceder diretamente a essa reparação" (cf. Justiça constitucional, tomo II, p. 442).

${ }^{136}$ Por sentença substitutiva entende-se o tipo de sentença que declara a inconstitucionalidade "de uma norma enquanto, na parte ou nos limites em que contém um prescrição em vez de outra" (cf. Rui Medeiros, A decisão de inconstitucionalidade, p. 456). Em outras palavras, é o tipo de sentença que "declara, por um lado, a inconstitucionalidade da norma na parte desta em que o Tribunal considera ser ilegítima e, por outro lado, acrescenta, em sua substituição, um critério de decisão diverso que deve ser conjugado com o segmento da norma não julgado inconstitucional" (cf. Carlos Blanco de Morais, Justiça constitucional, tomo II, p. 447).

${ }^{137}$ Nas palavras de Carlos Blanco de Morais, as sentenças demolitórias definem-se como "sentenças redutivas com efeitos aditivos, dado que, ao eliminarem uma norma presente numa dada disposição, ampliam o âmbito aplicativo de outra norma (que pode ou não encontrar-se presente na referida disposição), cujo conteúdo se encontrava restringido pela primeira". Cf. Justiça constitucional, tomo II, p. 423.

${ }^{138}$ Mais uma vez, ressalta-se o conceito oferecido pelo supracitado Carlos Blanco de Morais: "as sentenças aditivas sem redução de texto supõem a eliminação do sentido normativo ideal emergente de uma disposição e a concomitante identificação, por parte da sentença de acolhimento, de uma norma ou segmento normativo que se encontrava em falta, dada a sua indispensabilidade para tornar o referido preceito conforme a Constituição”. Cf. Justiça constitucional, tomo II, p. 430.
} 
A ilustração gráfica abaixo, com duas colunas justapostas, representa a diferença no alcance normativo de dois regimes jurídicos distintos que são comparados para fins de verificação do respeito ao direito de igualdade.

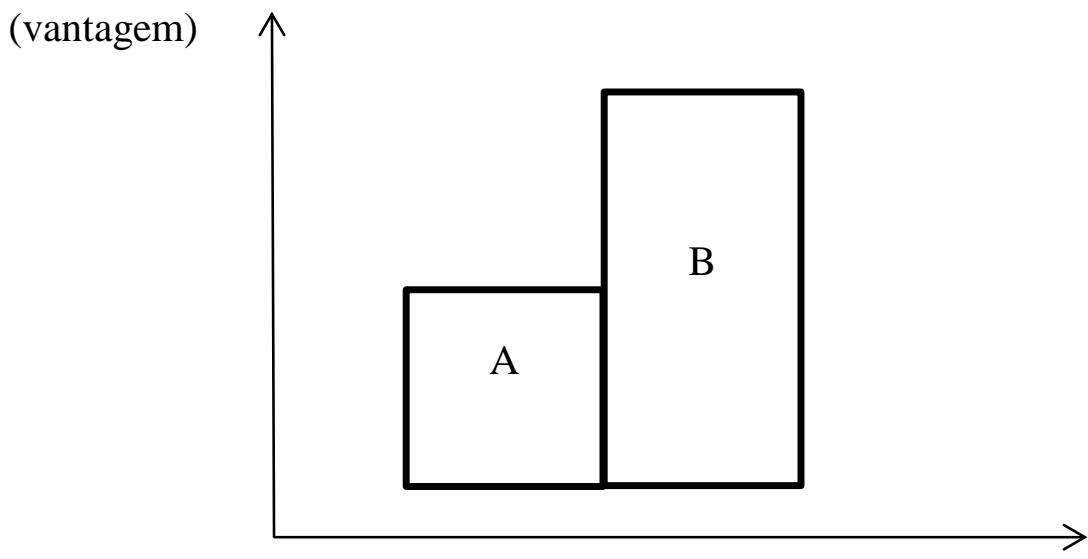

(regimes jurídicos)

$\mathrm{Na}$ figura acima, verifica-se que dois regimes normativos, $\mathrm{A}$ e B, quando colocados em comparação, lado a lado, assumem patamares distintos. Enquanto o regime B se mostra mais vantajoso, A encontra-se em uma situação inferior quando comparado a B. Neste caso, se a equivalência entre ambos for exigida, a jurisdição constitucional terá como objeto de sanção não as normas em si, mas sim a diferença entre ambas. Isto é, nem A nem B deverão ser abordadas isoladamente, mas sim em conjunto, visto que a igualdade, caso reconhecida como necessidade de tratamento equiparado, seria incompatível apenas com a diferença existente entre A e B.

Para se reparar a inconstitucional diferença de tratamento, equiparando-se os regimes normativos segundo os ditames da igualdade aritmética, duas soluções despontam intuitivamente: (i) reduzir o alcance da norma B até que esta chegue ao mesmo nível da norma B; ou (ii) aumentar o alcance da norma A até equipará-la ao patamar da norma B.

No primeiro caso (i), seria necessária uma diminuição parcial do regime B. Por isso, não seria a sanção pura de nulidade do regime jurídico $\mathrm{B}$ a melhor solução, visto que provocaria a eliminação do regime por inteiro, deixando os sujeitos submetidos a seu regime numa situação agora inferior comparativamente ao regime jurídico A: um regime mais vantajoso tornar-se-ia menos vantajoso, ao passo que deveria se tornar equivalente. Por aí se vê que, nesta situação, a equiparação entre os 
regimes exigiria não a eliminação pura e simples do regime $\mathrm{B}$, mas sim uma manipulação de seu alcance, de modo a reduzi-lo sem eliminá-lo. Rigorosamente, seria necessária uma decisão que, após declarar a nulidade do regime $\mathrm{B}$, retirando-o do ordenamento, promovesse uma reconstrução analógica do ordenamento, de sorte a determinar que o regime jurídico A deve abranger as situações ou sujeitos anteriormente submetidos ao regime B. Esta reconstrução, pautada numa atividade de integração do ordenamento jurídico, corresponde ao designado efeito aditivo da decisão judicial ${ }^{139}$.

Na segunda solução (ii), a complexidade também seria patente. Do mesmo modo que a redução parcial do regime $\mathrm{B}$ requer uma atuação judicial especial, o aumento do alcance do regime jurídico A também não pode ser pacificamente oferecido pelas decisões pautadas no binômio inconstitucionalidade-nulidade, por razões óbvias: não seria lógico que uma sanção de nulidade incidente sobre o regime A tivesse o condão de, per se, conduzi-lo ao mesmo patamar do regime $\mathrm{B}$, incrementando seu alcance. Para que isso ocorresse, seria necessária a prolação de uma sentença que, da mesma forma que na hipótese (i), declarasse a inconstitucionalidade do regime normativo A e, numa operação integrativa, determinasse que, em nome da igualdade, o regime normativo B deveria ser estendido ao âmbito de proteção anteriormente regulado pelo regime $\mathrm{A}$, o que configuraria uma aplicação analógica do regime B às situações ou sujeitos anteriormente abrangidos pelo regime A.

Pelo exposto, percebe-se que as sentenças de efeitos aditivos tem como âmago o papel desempenhado pelos órgãos judiciais no sentido de integrar lacunas normativas, sendo que tais lacunas resultam, na verdade, de suas próprias decisões (lacunas aparentes de criação jurisdicional) ${ }^{140}$. Em outras palavras, o efeito aditivo é uma ferramenta utilizada pela jurisdição constitucional para reconstruir relações normativas que foram, no mesmo ato e pelo mesmo órgão, sancionadas de nulidade e

\footnotetext{
${ }^{139}$ Cabe esclarecer, nesta oportunidade, que o efeito aditivo não corresponde, exatamente, a uma "adição de direitos", mas sim a uma extensão de regimes jurídicos pautada na integração de lacunas normativas. Assim, uma sentença de efeitos aditivos também poderia ser empregada em decisões que reduzem direitos, como seria o caso de equiparações "por baixo", em que o regime mais benéfico é diminuído ao patamar do menos benéfico.

${ }^{140}$ A definição é de Carlos Blanco de Morais: "as lacunas aparentes de criação jurisdicional têm lugar a partir do momento em que o Tribunal Constitucional se confronta com um virtual vazio de regulação, derivado de uma decisão de inconstitucionalidade por ele proferida". Cf. Justiça Constitucional, p. 849.
} 
expulsas do ordenamento. Com isso, o órgão judicial repara o vício e corrige a deficiência das normas positivadas ${ }^{141}$.

É certo que as sentenças manipulativas, em especial as sentenças de efeitos aditivos, configuram tipos decisórios de legitimidade controvertida, visto que, ao preencherem vazios normativos criados por eles mesmos, os órgãos judiciais se aproximam da atividade legislativa. Esse tema, contudo, será abordado no capítulo terceiro, que trata dos aspectos relativos à competência para promover a restauração do estado de igualdade constitucional. Por ora, cabe apenas fixar conceitos e definir a tipologia decisória da jurisdição constitucional da igualdade.

Feita a ressalva, este trabalho volta-se para a análise de outra espécie decisória de larga utilidade para o desenvolvimento do tema, qual seja, a sentença de modulação de efeitos.

\subsubsection{Sentença de Modulação de Efeitos}

No direito brasileiro, consagrou-se a ideia de que a decisão de inconstitucionalidade acarreta, em regra, na sanção de nulidade ex tunc do preceito declarado incompatível com a Constituição, razão pela qual se entende que ela é dotada de uma eficácia declaratória e retroativa ${ }^{142}$. Em outras palavras, prevalece na prática constitucional brasileira que a decisão de inconstitucionalidade remonta ao nascimento da norma, reconhecendo-a inválida desde então. Tal como avaliado no estudo das sentenças simples, esta modelagem tem inspiração norte-americana.

Apesar dessa tradicional sistemática de controle e sanção das normas inconstitucionais, novas técnicas têm sido utilizadas para se atenuar a rigidez típica da sanção retroativa. Assim, sob o pálio de imperativos de segurança jurídica e excepcional interesse público, a jurisdição constitucional brasileira tem realizado a prolação de

\footnotetext{
${ }^{141}$ Mais uma vez, cita-se percuciente comentário de Carlos Blanco de Morais: "E obtém-se, finalmente, por força de uma decisão que, simultaneamente, julga a inconstitucionalidade do segmento de uma norma, mas procede também à reparação do vício, juntando um "quid" normativo extraído do ordenamento, susceptível e permitir à norma assim 'reconstruída', produzir no futuro efeitos jurídicos válidos (sentenças com efeitos aditivos)". Cf. "As sentenças com efeitos aditivos", in: As sentenças intermédias da justiça constitucional, p. 19.

${ }^{142}$ Nesse sentido, ensina Elival da Silva Ramos: "as decisões de controle assumem natureza meramente declaratória, isto é, de mera certificação de uma nulidade preexistente. A sanção em si opera de pleno direito, isto é, independentemente de decisão judicial, remontando ao nascimento do ato legislativo". Cf. Controle de constitucionalidade no Brasil, p. 296.
} 
decisões de inconstitucionalidade com eficácia ex nunc, ou seja, dotadas de um caráter constitutivo negativo que, de um lado, erradicam do ordenamento a norma inconstitucional, mas, por outro lado, mantém seus efeitos pretéritos, resguardando as relações jurídicas constituídas sob a vigência da lei inconstitucional ${ }^{143}$. Essa prática tem sido abordada, no Brasil, sob a nomenclatura modulação de efeitos.

Essa modalidade decisória, apesar de receber uma investigação própria, também se enquadra no conceito de sentença manipulativa, pois nada mais faz do que modificar (manipular) os efeitos temporais típicos das decisões de inconstitucionalidade. Nada obstante, optou-se por analisá-la em apartado, haja vista sua peculiar racionalidade, distinta daquela que se volta para a manipulação do sentido da norma objeto de controle.

O primeiro aspecto a ser destacado refere-se ao fato de que a eficácia temporal ex nunc, típica de decisões constitutivas negativas, não representa, propriamente, uma novidade na teoria do controle de constitucionalidade. Prova disso é que esta é a prática no sistema judicial europeu, cujo contencioso constitucional é concentrado em Cortes ou Tribunais Constitucionais. Neste ambiente, o controle de constitucionalidade se desenhou, desde os primórdios, como um sistema em que os atos legislativos gozam de validade até que sobrevenha decisão anulatória que lhes retire a validade, o que é feito, em regra, sem efeito retroativo, razão pela qual subsistem as consequências jurídicas produzidas antes da anulação ${ }^{144}$.

De qualquer modo, nos países que tradicionalmente adotaram o sistema judicial norte-americano, a decisão jurisdicional de eficácia temporal prospectiva traduz uma novidade. No Brasil, esta é uma possibilidade prevista em lei desde $1999^{145}$ e vem

\footnotetext{
${ }^{143}$ Carlos Blanco de Morais bem traduz a motivação dessa modalidade decisória: "trata-se das sentenças que têm como objetivo principal restringir temporalmente, na totalidade ou em parte, os seus efeitos sancionatórios com carácter retroactivo, de modo a preservar situações jurídicas constituídas no decurso da vigência da norma inconstitucional". Cf. Justiça constitucional, tomo II, p. 281.

${ }^{144}$ A sistemática foi defendida por Hans Kelsen: "Resulta de nossas explicações precedentes que, se quisermos que a Constituição seja garantida com eficácia, é necessário que o ato submetido ao controle do tribunal constitucional seja diretamente anulado por decisão própria, se considerado irregular. Essa decisão, mesmo se se referir a normas gerais - e é precisamente esse o caso principal -, deve ter força anulatória. (...) Em todo caso, seria bom, no interesse da mesma segurança jurídica, não atribuir em princípio nenhum efeito retroativo à anulação das normas gerais, pelo menos no sentido de deixar subsistirem todos os actos jurídicos anteriormente produzidos com base na norma em questão". Cf. Jurisdição constitucional, $2^{a}$ ed. São Paulo: Martins Fontes, 2007, pp. 170-171.

${ }^{145}$ Basta verificar o artigo 27 da Lei 9.868/99: “Ao declarar a inconstitucionalidade de lei ou ato normativo, e tendo em vista razões de segurança jurídica ou de excepcional interesse social, poderá o Supremo Tribunal Federal, por maioria de dois terços de seus membros, restringir os efeitos daquela
} 
sendo aplicada com frequência pelo nosso órgão judicial de cúpula, o Supremo Tribunal Federal. Hoje, entende-se que este tribunal tem o poder de, verificados alguns pressupostos previstos em lei, modular os efeitos da decisão de inconstitucionalidade, seja definindo sua aplicabilidade desde a data da decisão, seja a partir de uma data futura, estipulada pelo próprio tribunal.

$\mathrm{Na}$ esfera da jurisdição constitucional da igualdade, é particularmente relevante o estudo da modulação de efeitos pro futuro. Como será analisado adiante (capítulo terceiro), existem hipóteses em que o vício de inconstitucionalidade somente pode ser solucionado com a reformulação completa de todo o arcabouço normativo em questão, performance esta que apenas pode ser desempenhada pelo poder legislativo. Quando for esta a situação, caberá ao órgão judicial prolatar uma decisão que seja apta a exortar o parlamento a corrigir a inconstitucionalidade. $\mathrm{O}$ instrumento adequado para este apelo ao legislador, no Brasil, é a postergação dos efeitos da decisão para uma data futura, a qual demarcará o termo final do período ofertado ao poder legislativo para sanar a inconstitucionalidade.

É certo que a modulação de efeitos para o futuro contém uma contradição intrínseca, qual seja, a cumulação de um juízo de invalidade com a decisão pela manutenção da norma no ordenamento. Isto é, apesar da constatação de uma inconstitucionalidade, não se aplica qualquer tipo de sanção imediata, seja ela de caráter declaratório (portanto, retroativa), seja ela de caráter constitutivo negativo (eficácia $e x$ nunc). Não por acaso se trata de uma ferramenta de aplicação controversa.

Nada obstante o contrassenso, a sanção de nulidade pro futuro encontra raízes numa singela cogitação da realidade: existem situações em que a eliminação de uma prescrição normativa inconstitucional não conduz à restauração do estado de constitucionalidade, mas sim geram um estado de maior inconstitucionalidade, ainda. São situações em que a supressão do preceito inconstitucional "pioraria" ainda mais a situação, agravando a inconstitucionalidade identificada.

Influenciados pela reflexão supra, diversos tribunais constitucionais europeus colocaram em prática modalidades decisórias que postergavam a sanção de nulidade, de modo a oportunizar ao parlamento tempo hábil para a positivação de novos

declaração ou decidir que ela só tenha eficácia a partir de seu trânsito em julgado ou de outro momento que venha a ser fixado". 
regimes jurídicos, então compatíveis com a Constituição. Na Alemanha, tornou-se comum a prolação de decisões que se limitam a constatar que uma regulação é "ainda constitucional" e exortam o legislador a promover a reparação, prática esta que passou a ser chamada de "apelo ao legislador" (Appellentscheidung) ${ }^{146}$. No mesmo sentido, o Tribunal Constitucional austríaco adota a figura do atraso na entrada em vigor da derrogação, a qual segue o mesmo padrão descrito, de reconhecimento da inconstitucionalidade sem sanção de nulidade ${ }^{147}$.

No que tange ao direito de igualdade, o instrumento é interessante não apenas porque a violação a igualdade se perfaz numa relação entre regimes jurídicos distintos cuja restauração requer, nalgumas ocasiões, uma ampla reforma da legislação envolvida, mas também porque, com frequência, inexiste uma solução determinada pela Constituição, mas sim uma variedade de soluções possíveis. Em termos simplórios, existem hipóteses em que o órgão judicial faz o seguinte raciocínio: “existem inúmeras regulações compatíveis com o direito de igualdade, mas o legislador positivou uma que não o é”. Neste caso, avulta a modulação de efeitos como uma técnica apta a conclamar o legislador para que reveja suas opções e aprove uma das várias regulações compatíveis com a igualdade constitucional, hipótese esta que propicia a instalação de um processo reparatório bilateral, com participação do poder judiciário e legislativo. Tal sistemática será oportunamente analisada.

Uma decisão desse tipo foi prolatada na ADI $1.842 / \mathrm{RJ}^{148}$, que teve por objeto a constitucionalidade da Lei Complementar 87/1997, da Lei n. 2.869 e do Decreto 24.631/1998, todos do Estado do Rio de Janeiro, que instituíram a Região Metropolitana do Rio de Janeiro e a Microrregião dos Lagos, transferindo a titularidade do poder concedente para prestação de serviços públicos de interesse metropolitano ao Estado do Rio de Janeiro. Após julgar inconstitucional a expressão "a ser submetido à Assembleia Legislativa", prevista a legislação citada, o tribunal modulou os efeitos da decisão pelo prazo de 24 meses, em razão do excepcional interesse social na

\footnotetext{
${ }^{146}$ Vale citar os ensinamentos de Gilmar Mendes sobre o assunto: "Não raro reconhece a Corte que a lei ou a situação jurídica não se tornou 'ainda' inconstitucional, conclamando o legislador a que proceda - às vezes dentro de determinado prazo - à correção ou à adequação dessa "situação ainda constitucional"'. Cf. Jurisdição constitucional: o controle abstrato de norma no Brasil e na Alemanha, $5^{\text {a }}$ ed. São Paulo: Saraiva, 2005, p. 296.

${ }^{147}$ Cf. Markus González Beilfuss, Tribunal Constitucional y reparación de la discriminación normativa, pp. 182-194.

${ }_{148}$ ADI 1.842/RJ; Relator(a) p/ Acórdão: Min. Gilmar Mendes; Julgamento: 06/03/2013; Órgão Julgador: Tribunal Pleno.
} 
continuidade da prestação do serviço de saneamento básico. A violação da igualdade, neste caso, não é patente, porém tem uma correlação indireta, à medida que um dos fundamentos para a decisão foi a exigência constitucional de participação dos municípios envolvidos no colegiado, não sendo constitucional a concentração do poder decisório nas mãos de qualquer ente (Estado do Rio de Janeiro). Ou seja, declarou-se necessária uma conjugação mais igualitária de forças entre municípios e Estadomembro, no colegiado metropolitano, ainda que essa correlação não fosse paritária $^{149}$.

Em suma, tal decisão encampou uma modulação de efeitos pro futuro porque a nulidade imediata agravaria a prestação do serviço público de saneamento básico e, também, porque existem diversas formas de se compatibilizar a participação dos entes federativos na região metropolitana, motivo pelo qual o tribunal entendeu que deveria remeter a solução da inconstitucionalidade ao poder legislativo.

\footnotetext{
${ }^{149} \mathrm{Da}$ ementa da decisão, consta a seguinte afirmação: "É necessário evitar que o poder decisório e o poder concedente se concentrem nas mãos de um único ente para preservação do autogoverno e da autoadministração dos municípios. Reconhecimento do poder concedente e da titularidade do serviço ao colegiado formado pelos municípios e pelo estado federado. A participação de cada Município e do Estado deve ser estipulada em cada região metropolitana de acordo com suas particularidades, sem que se permita que um ente tenha predomínio absoluto".
} 


\section{III) COMPETÊNCIA REPARATóRIA}

3.1. Considerações gerais; 3.2. Arquitetura da igualdade; 3.2.1. Quadro geral; 3.2.2. Diferenciação; 3.2.3. Equiparação; 3.2.4. Desconstrução; 3.3. Modelo unilateral; 3.3.1. Características; 3.3.2. Admissibilidade; 3.3.3. Requisitos; 3.4. Modelo bilateral; 3.4.1. Características; 3.4.2. Admissibilidade; 3.4.3. Requisitos.

\subsection{CONSIDERAÇões GERAIS}

Mais do que identificar as violações ao direito de igualdade, é tarefa da jurisdição constitucional reparar tais afrontas, de modo a eliminar a inconstitucionalidade do ordenamento jurídico e, com isso, garantir a integridade do sistema da Constituição ${ }^{150}$. Nesta missão, contudo, não só os fundamentos da tutela judicial da igualdade devem ser avaliados, como a relação de inconstitucionalidade, suas formas e os tipos de decisão que daí decorrem, aspectos estes analisados no capítulo anterior. É necessário, também, que sejam estudadas as contingências institucionais que envolvem a atividade de reparação das violações à igualdade constitucional.

Conforme será avaliado ao longo deste capítulo, a atividade de correção das afrontas ao direito constitucional de igualdade nem sempre compete, exclusivamente, ao poder judiciário, havendo casos em que este poder encontra limites que o impedem de restaurar o ordenamento jurídico.

Em que circunstâncias é legítimo ao poder judiciário restaurar, de modo direto e por força própria, o estado de constitucionalidade requerido pelo direito de igualdade (modelo unilateral), e em que circunstâncias será necessária a participação do poder legislativo (modelo bilateral)? Quem tem a competência para reparar afrontas à

\footnotetext{
${ }^{150}$ Tal como ensina Jorge Miranda, a garantia da constitucionalidade requer a eliminação dos "elementos estranhos na ordem jurídica". Em suas palavras, "a garantia da constitucionalidade é a garantia de que, em cada relação jurídica, rege uma norma conforme ao dispositivo constitucional e de que se pratica um acto permitido pela Constituição”. Cf. Contributo para uma teoria da inconstitucionalidade, p. 237.
} 
igualdade? ${ }^{151}$ Eis as principais questões deste capítulo, que se dedica à análise dos problemas de ordem funcional que envolvem a restauração do estado de constitucionalidade requerido pela Constituição.

Antes, porém, de se avançar no estudo da matéria, cabe uma análise das modalidades lógicas de reparação da igualdade, as quais indicarão a variedade de correções compatíveis com o direito de igualdade. Nesse escopo, foi elaborado um item com ilustrações dos métodos lógicos de reparação da igualdade, alinhados sob o título de arquitetura da igualdade. Para se demonstrar a importância dessa metodologia, foram citados casos da jurisprudência do Supremo Tribunal Federal em que se verificou cada um dos métodos.

\subsection{ARQuitetura da IgUALDADE}

\subsubsection{Quadro Geral}

O objeto deste tópico, que investiga a arquitetura da igualdade, é classificar os métodos lógicos de reparação da igualdade. Tal explanação é necessária à medida que a recomposição da igualdade pode assumir várias formatações, o que fica claro quando se utiliza a representação gráfica da igualdade, com duas colunas justapostas que correspondem aos regimes normativos postos em comparação. Por esta figura, percebe-se que a igualdade pode ser alcançada com vários movimentos, sejam eles no sentido de incrementar vantagens ou de reduzi-las, de modo a equiparar ou diferenciar os regimes jurídicos em exame.

No que concerne à reparação de lesões à igualdade constitucional, é possível classificar a sua reparação em duas hipóteses gerais. São elas:

a) quando há uma equiparação inconstitucional (por exigência de igualdade proporcional), exige-se uma diferenciação dos sujeitos ou regimes em comparação, (a.1) seja reduzindo o alcance de um dos regimes positivado (diferenciação por redução), (a.2) seja incrementando a vantagem normativa de um dos regimes envolvidos

\footnotetext{
${ }^{151}$ De acordo com Robert Alexy, o problema do enunciado geral da igualdade tem como uma de suas questões a determinação sobre "a quem compete - ao legislador ou ao juiz constitucional - decidir de forma vinculante em última instância acerca desses juízos de valor". Cf. Teoria dos direitos fundamentais, p. 400 .
} 
(diferenciação por ampliação), ou então (a.3.) desconstruindo ambos os regimes, no caso desta desconstrução gerar a aplicação de um regime jurídico latente que seja equiparado.

b) quando se trata de uma diferenciação inconstitucional (por incidência da igualdade paritária ou da igualdade proporcional entre iguais), requer-se uma equiparação dos sujeitos ou regimes em comparação, (b.1) seja reduzindo o nível de benefício de um deles (equiparação por redução); (b.2) seja expandindo a vantagem normativa de um dos regimes envolvidos (equiparação por ampliação); ou então (b.3) desconstruindo ambos os regimes em comparação, na hipótese disso resultar na aplicação de regimes que, antes latentes no ordenamento, passem a constituir a diferenciação dos regimes.

Para ilustrá-las, mostra-se útil a construção gráfica da igualdade que, novamente, emprega a sistemática de duas colunas justapostas para demonstrar a diferença existente entre um sujeito ou regime normativo mais vantajoso (coluna maior) e o sujeito ou regime em situação inferior, lembrando que uma situação mais vantajosa pode decorrer tanto da maior abrangência de direitos, quanto da menor abrangência de obrigações. Porém, agora são acrescentadas linhas tracejadas e flechas para indicar a forma utilizada na reparação judicial. 


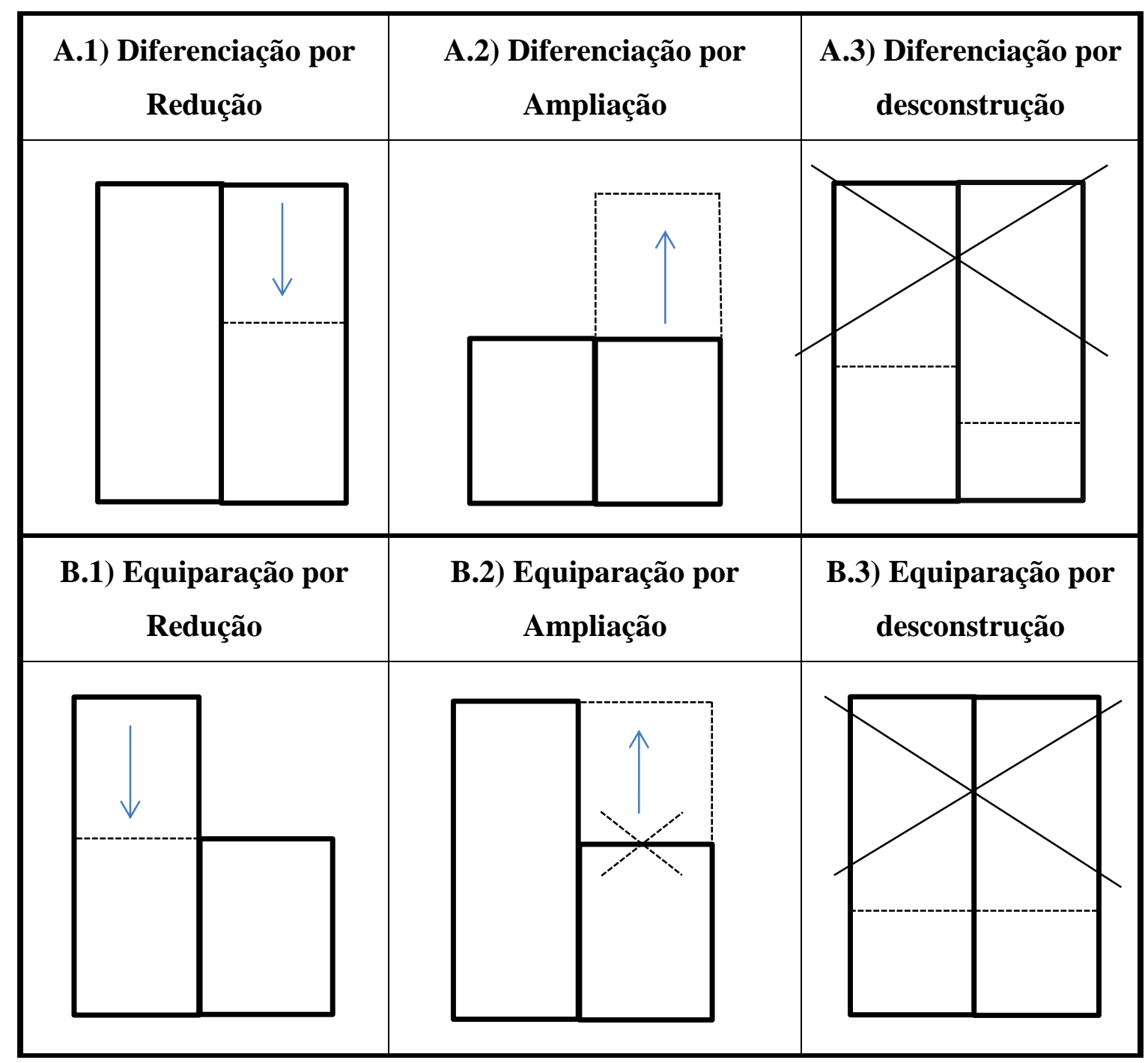

Feito esse esboço geral, envereda-se para o exame de cada um dos formatos, relembrando que, no intuito de se demonstrar a importância e o caráter pragmático do estudo, foram utilizados exemplos extraídos da jurisprudência do Supremo Tribunal Federal. Na oportunidade, serão feitas algumas considerações relativas à tipologia das decisões proferidas.

\subsubsection{Diferenciação}

A sentença de diferenciação (figuras "A.1" e "A.2") configura um tipo decisório peculiar no estudo das formas de reparação das violações à igualdade constitucional. Ao contrário das sentenças de equiparação - que corrigem diferenças de tratamento buscando estabelecer níveis equivalentes -, a sentença de diferenciação atua 
sobre tratamentos equiparados, de sorte a buscar uma diferenciação que atenda às naturezas distintas dos sujeitos ou regimes normativos comparados. Trata-se de uma aplicação concreta da máxima de que desiguais devem ser tratados de modo desigual, na medida de suas desigualdades (igualdade proporcional).

Apesar da sua singularidade, a sentença de diferenciação encontra eco na jurisprudência do Supremo Tribunal Federal. Exemplo disso é o julgamento da Ação Direta de Inconstitucionalidade $\mathrm{n}^{\mathrm{o}} 1.946^{152}$, que tratou da constitucionalidade do artigo 14 da Emenda Constitucional $n^{\circ}$ 20, de 1998, que submeteu todos os benefícios do Regime Geral de Previdência Social ao teto da previdência, inclusive o benefício da licença maternidade. $\mathrm{O}$ regime jurídico a ser aplicado a este benefício foi questionado porque dificultava a contratação de mulheres, uma vez que quando estas fizessem usufruto do benefício, o empregador teria que arcar com todo o salário que ficasse além do teto da previdência, o que gerava um "encarecimento" da mão de obra feminina. Neste caso, o tribunal reputou que a submissão do benefício da licença maternidade ao teto de cobertura da previdência social violava a regra constitucional da "proibição de diferença de salários, de exercício de funções e de critério de admissão por motivo de sexo...", prevista no inciso XXX do artigo $7^{\circ}$ da Constituição. Destarte, o Supremo Tribunal Federal, por unanimidade, julgou procedente a ação.

Outro exemplo de atuação judicial que resultou na diferenciação de regimes equiparados, sob o argumento de haver uma distinção ensejadora de tratamento desigual, pode ser encontrado no recente Recurso Extraordinário 559.937/RS ${ }^{153}$, relativo à tributação da PIS/COFINS Importação.

No acórdão citado, nota-se que o tributo PIS/Cofins Importação, apesar de configurar um tributo de natureza distinta do Pis/Cofins incidente em operações internas, recebia do legislador ordinário um tratamento equivalente a este no que tange à formação da base de cálculo. A Lei 10.865/04, ao instituir o PIS/Cofins - Importação, desconsiderou a imposição constitucional de que as contribuições sociais sobre a importação que tenham alíquota ad valorem sejam calculadas com base no valor aduaneiro. Questionada a legalidade da equiparação, a Fazenda Nacional suscitou a

\footnotetext{
152 ADI 1946 / DF - DISTRITO FEDERAL; Relator(a): Min. SYDNEY SANCHES; Julgamento: 03/04/2003; Órgão Julgador: Tribunal Pleno.

${ }^{153}$ RE 559937 / RS - RIO GRANDE DO SUL; Relator(a): Min. ELLEN GRACIE; Relator(a) p/ Acórdão: Min. DIAS TOFFOLI; Julgamento: 20/03/2013; Órgão Julgador: Tribunal Pleno
} 
necessidade de tratamento isonômico entre os tributos e, portanto, entre as mercadorias adquiridas no mercado interno e no mercado externo, o que teria motivado a introdução, na base de cálculo do tributo o ICMS-Importação e a própria PIS/Cofins.

Invocado, o Supremo Tribunal Federal julgou inconstitucional a equiparação pretendida pelo legislador federal, fundamentando sua decisão na natureza distinta dos tributos. Da ementa, consta expressamente a afirmação de que "são tributos distintos", o que levou ao entendimento de que "o gravame das operações de importação se dá não como concretização do princípio da isonomia, mas como medida de política tributária". Ao decidir dessa forma, o tribunal declarou a inadequação de um tratamento paritário entre os regimes jurídicos. Tratando-se de tributos com formatação desigual e de contribuintes não passíveis de equiparação, não caberia falar em isonomia (no sentido de paridade) dos tributos ${ }^{154}$.

\subsubsection{Equiparação}

Ao contrário do que se passa com as sentenças de diferenciação, que raramente emergem na prática jurisprudencial, as sentenças de equiparação são a tônica da jurisdição constitucional da igualdade, nem tanto porque sejam proferidas com facilidade, mas sim porque são pleiteadas com frequência, merecendo contínuas e renovadas análises pelos órgãos judiciais. A razão disso, como já assinalado, está no fato de que, em regra, as demandas relativas ao direito de igualdade objetivam equiparar regimes. Pleiteia-se, comumente, o recebimento do mesmo tratamento legal que aquele oferecido a um terceiro (tertium comparationis) que, na visão do autor da demanda, deve receber o mesmo tratamento.

As sentenças de equiparação dividem-se em dois tipos básicos: a sentença de equiparação por redução e a de equiparação por ampliação.

A primeira diz respeito à reparação que atua sobre o regime mais vantajoso, reputando-o inconstitucional na medida do seu excesso, de modo a reduzir seu alcance

\footnotetext{
${ }^{154}$ Vale citar observação feita pela Min. Ellen Gracie, relatora originária do processo: "No caso em discussão, contudo, não há parâmetro de comparação adequado que permita conclusão no sentido de que a circunscrição das contribuições sobre a importação à base valor aduaneiro viole a isonomia e que, de outro lado, a inserção do ICMS-Importação e das próprias contribuições PIS/PASEP-Importação e COFINS-Importação na base de cálculo destas últimas sem um imperativo constitucional de isonomia tributária”. Cf. RE 559.937/RS, p. 21.
} 
normativo. Usualmente, este tipo decisório é empregado nas situações em que se verificam privilégios inconstitucionais, casos em que o vício não está, propriamente, em um tratamento depreciativo ou aviltante, mas sim em um tratamento preferencial. Simplesmente, dentro da esfera abrangente de um regime normativo, cria-se um regime mais benéfico para um ou alguns poucos escolhidos dentro de um universo que merece, em razão da igualdade constitucional, tratamento equiparado, justamente por não possuir características próprias e ímpares aptas a fundamentar um tratamento normativo especial.

Por outro lado, a equiparação por ampliação refere-se à modalidade que, para restaurar a igualdade constitucional, promove a extensão, a ampliação, o incremento do regime normativo inferior, até que este alcance o patamar do regime normativo em comparação. Esta é a solução comumente encontrada quando existe uma exclusão ou constrição que viola a igualdade constitucional, ou seja, quando a inconstitucionalidade decorre de uma ação legislativa que afasta determinado sujeito do âmbito de incidência de um regime normativo oferecido a seus pares, ou então reduz o alcance do regime normativo de um sujeito que merece, em razão da igualdade constitucional, tratamento equivalente ao sujeito beneficiado.

A seguir, são analisadas cada uma das espécies de equiparação.

No que se refere à sentença de equiparação por redução, podem ser citados os precedentes do Supremo Tribunal Federal quanto aos limites do foro por prerrogativa por função. Nesse tema, é interessante observar a ADI 2.797-2/DF ${ }^{155}$, pela qual o tribunal julgou inconstitucional a Lei 10.628 que, ao reformar o art. 84, §1 ${ }^{\circ}$, do Código de Processo Penal, estendeu o foro especial para momento posterior à cassação da investidura na função. Na ocasião, também foi julgado inconstitucional o acréscimo do $\S 2^{\circ}$ ao art. 84 do Código de Processo Penal, que criou foro por prerrogativa de função para as ações de improbidade administrativa.

No mesmo sentido da decisão acima, pode ser citado o acórdão proferido no Inquérito 687-4/MG $\mathrm{AgRg}^{156}$, no qual o tribunal afirmou que e "as prerrogativas de foro, pelo privilégio, que, de certa forma, conferem, não devem ser interpretadas

${ }^{155}$ ADI 2797 / DF; Relator(a): Min. SEPÚLVEDA PERTENCE; Julgamento: 15/09/2005; Órgão Julgador: Tribunal Pleno.

${ }^{156}$ Inq 687 QO / SP - SÃO PAULO; Relator(a): Min. SYDNEY SANCHES; Julgamento: 25/08/1999 Órgão Julgador: Tribunal Pleno 
ampliativamente, numa Constituição que pretende tratar igualmente os cidadãos comuns, como são, também, os ex-exercentes de tais cargos ou mandatos". Na mesma esteira, no Inquérito $1.376-4 / \mathrm{MG}^{157}$ foi decidido que entendimento contrário acarretaria “inaceitável privilégio de caráter pessoal", o que "transgride valor fundamental à própria configuração da ideia republicana, que se orienta pelo vetor axiológico da igualdade".

Também são elucidativas as decisões do Supremo Tribunal Federal relativas à igualdade das partes no processo. Sobre o tema, o tribunal já decidiu, na Ação Direita de Inconstitucionalidade $\mathrm{n}^{\mathrm{o}} 1.753-2 / \mathrm{DF}^{158}$, que é inconstitucional a ampliação do prazo de decadência da ação rescisória de dois para cinco anos quando proposta pelo Poder Público (União, Estados, Distrito Federal, Municípios e suas autarquias e fundações públicas), justamente por configurar privilégio contrário à igualdade constitucional (na vertente da igualdade paritária, aritmética). Nessa esteira, consta da fundamentação proferida pelo tribunal que "quando uma das partes é o Estado, a jurisprudência tem transigido com alguns favores legais que, além da vetustez, tem sido reputados não arbitrários por visarem a compensar dificuldades da defesa em juízo das entidades públicas; se, ao contrário, desafiam a medida da razoabilidade ou da proporcionalidade, caracterizam privilégios inconstitucionais".

No plano tributário, podem ser citados casos em que foram julgadas inconstitucionais isenções fiscais atribuídas a sujeitos específicos, sem qualquer razão que justificasse um tratamento especial. É o que ocorreu na Ação Direta de Inconstitucionalidade $\mathrm{n}^{\mathbf{o}} 3.334^{159}$, por exemplo, em que o Supremo Tribunal Federal declarou a inconstitucionalidade do artigo 240 da lei complementar 165/1999 do Estado do Rio Grande do Norte, que havia concedido isenção de custas e emolumentos aos membros e servidores do poder judiciário. No mesmo viés, o tribunal decidiu, no Recurso Extraordinário 236.881/RS ${ }^{160}$, que é inconstitucional a isenção do imposto de renda incidente sobre a verba de representação de Magistrados, autorizada pelo Decretolei $2.019 / 83$.

\footnotetext{
${ }^{157}$ Inq 1376 AgR / MG - MINAS GERAIS; Relator(a): Min. CELSO DE MELLO; Julgamento: 15/02/2007; Órgão Julgador: Tribunal Pleno.

${ }^{158}$ ADI 1753 MC / DF - DISTRITO FEDERAL; Relator(a): Min. SEPÚLVEDA PERTENCE; Julgamento: 16/04/1998; Órgão Julgador: Tribunal Pleno.

159 ADI 3334 / RN - RIO GRANDE DO NORTE; Relator(a): Min. RICARDO LEWANDOWSKI; Julgamento: 17/03/2011; Órgão Julgador: Tribunal Pleno.

${ }^{160}$ RE 236881 / RS - RIO GRANDE DO SUL; Relator(a): Min. MAURÍCIO CORRÊA; Julgamento: 05/02/2002; Órgão Julgador: Segunda Turma.
} 
Em todos os casos citados, regimes jurídicos foram equiparados com a eliminação de privilégios, o que configura uma equiparação por redução.

No que tange à sentença de equiparação por ampliação, é preciso destacar desde já que sua formatação difere quando a jurisdição lida com diferenciações explícitas e quando trata de diferenciações implícitas ${ }^{161}$, sendo distinta a racionalidade das sentenças que encaram cada uma das hipóteses. $\mathrm{Na}$ primeira delas (inconstitucionalidades explícitas), não há maiores dificuldades de identificação e correção, ao contrário do que ocorre na segunda hipótese (inconstitucionalidade implícita). Isso porque, quando se trata de verificar a constitucionalidade de uma norma que explicitamente exclui um sujeito do âmbito normativo genérico que originariamente o incluía, ou então explicitamente reduz o alcance do regime normativo de apenas um sujeito dentre vários que eram tratados da mesma forma, a violação à igualdade é facilmente identificada - pois explícita -, assim como a correção judicial por (re)equiparação não demanda maiores esforços de justificação, haja vista que a ampliação do regime inferior é consequência automática da declaração de inconstitucionalidade da ação excludente perpetrada pelo legislador.

Um caso da jurisprudência do Supremo Tribunal Federal em que se constata uma ação excludente explicitamente inconstitucional, corrigida mediante uma sentença de equiparação por ampliação, é a ADI 1.351/DF ${ }^{162}$, que tratou da chamada cláusula de desempenho, já citada neste trabalho. Nesta ação, que teve por objeto a declaração de inconstitucionalidade de dispositivos da Lei $n^{\circ}$ 9.096/95 à medida que determinavam a algumas restrições a partidos políticos que não cumprissem alguns requisitos mínimos. O que essa lei estabelecia, em suma, era uma distinção entre partidos com base no critério da representatividade congressual dos mesmos, pois aqueles partidos que não atingissem patamares mínimos de votação, estabelecidos no artigo 13 da referida lei, estariam sujeitos às reduções aduzidas.

No processo descrito, o Supremo Tribunal Federal julgou procedente a ação direta e declarou a inconstitucionalidade dos dispositivos que estabeleciam a diferenciação entre os partidos políticos, bem como das consequências previstas para aqueles que não atingissem o patamar mínimo de representatividade. Com isso, o

\footnotetext{
${ }^{161}$ Sobre o tema, conferir item 2.3.3 deste trabalho.

162 ADI 1351 / DF - DISTRITO FEDERAL; Relator(a): Min. MARCO AURÉLIO; Julgamento: 07/12/2006; Órgão Julgador: Tribunal Pleno.
} 
tribunal restabeleceu o regime provisório anterior, que possuía uma relação de igualdade distinta. Por conta da decisão judicial, partidos menores que seriam alvo de restrições, foram alçados ao mesmo patamar daqueles que preenchem as condições de representatividade mínima.

Entretanto, como dito, as maiores dificuldades, no campo das sentenças de equiparação por ampliação, estão nas exclusões implícitas. Consoante a própria nomenclatura indica, algumas exclusões não estão expressas na legislação, razão pela qual somente podem ser identificadas mediante uma interpretação sistemática que reconheça regimes normativos tacitamente excludentes. Outra dificuldade está na correção judicial dessas exclusões. Afinal, não havendo texto legislativo que viole a igualdade constitucional, cabe ao órgão de jurisdição constitucional atuar sobre normas ideais, ou seja, sobre interpretações e/ou aplicações de dispositivos legais. Ou seja, para se restaurar a igualdade constitucional implicitamente violada é necessário o proferimento de sentenças aditivas sem redução de texto. Nestas decisões, o tribunal elimina o segmento normativo ideal excludente e, ao reconstruir a norma de acordo com a igualdade constitucional, opera verdadeira ampliação do regime normativo antes excluído (e, portanto, inferior).

Não é difícil encontrar decisões do Supremo Tribunal Federal neste sentido. Dentre elas, é possível citar a sentença proferida na Ação Direta de Inconstitucionalidade $\mathrm{n}^{\mathrm{o}} 2.652 / \mathrm{DF}^{163}$, que impugnava a discriminação entre advogados privados e públicos perpetrada pelo parágrafo único do artigo 14 do Código de Processo Civil. Tratava-se de dispositivo que, a partir da redação oferecida pela Lei 10.358/03, ressalvava da incidência de multa por obstrução à justiça apenas os advogados que se sujeitavam "exclusivamente aos Estatutos da OAB". Alegava-se, no caso, a ocorrência de uma violação à igualdade constitucional (no sentido de paridade), à medida que o dispositivo discriminava negativamente os advogados vinculados a entes estatais, deixando-os em situação inferior aos advogados privados. A solução encontrada pelo tribunal foi julgar a ação procedente para, com isso, equipar o regime jurídico dos advogados públicos e privados, incrementando o benefício dos advogados públicos.

\footnotetext{
163 ADI 2652 / DF - DISTRITO FEDERAL; Relator(a): Min. MAURÍCIO CORRÊA; Julgamento: 08/05/2003; Órgão Julgador: Tribunal Pleno.
} 
Outro acórdão que pode ser citado neste contexto diz respeito à decisão do Supremo Tribunal Federal nas ações que discutiam a constitucionalidade das uniões estáveis homoafetivas (Ação de Descumprimento de Preceito Fundamental no 132/RJ ${ }^{164}$ e Ação Direta de Inconstitucionalidade $\mathrm{n}^{\circ} 4.277 / \mathrm{DF}^{165}$ ). Tais ações pleiteavam, basicamente, a aplicação do regime normativo oferecido às uniões estáveis heteroafetivas também às uniões homoafetivas, numa clara manifestação no sentido da equiparação entre os regimes normativos dos diferentes casais. Fundado na igualdade constitucional, o Supremo Tribunal Federal declarou a impossibilidade de o sexo constituir fator de diferenciação jurídica e equiparou o regime das uniões homoafetivas ao regime das uniões heterossexuais.

Por aí se vê que as sentenças de equiparação por ampliação, sejam elas decorrentes de exclusões explícitas ou implícitas, estão na pauta cotidiana do Supremo Tribunal Federal, não faltando exemplos para demonstrar que o direito de igualdade configura parâmetro de controle onipresente nas mais diversas relações jurídicas e que, não raro, justificam a remodelagem de regimes normativos.

\subsubsection{Desconstrução}

Por último, a equiparação por desconstrução refere-se ao modelo corretivo que elimina tanto o regime normativo superior quanto o inferior. Embora configure uma solução rara na jurisprudência do Supremo Tribunal Federal, ela tem sua importância à medida que representa uma radical sanção para a violação da igualdade constitucional. Por ela, reputa-se inconstitucional não apenas o excesso do regime mais vantajoso ou a insuficiência do regime menos benéfico, mas ambos os regimes. Nesta hipótese, em geral a inconstitucionalidade estará na utilização de um critério incompatível com a finalidade da distinção. Por esta razão, considera-se inconstitucional a diferenciação como um todo.

Ao menos um caso da jurisprudência do Supremo Tribunal Federal recebeu esta solução.

\footnotetext{
${ }^{164}$ ADPF 132 / RJ - RIO DE JANEIRO; Relator(a): Min. AYRES BRITTO; Julgamento: 05/05/2011; Órgão Julgador: Tribunal Pleno.

${ }_{165}$ ADI 4277 / DF - DISTRITO FEDERAL; Relator(a): Min. AYRES BRITTO; Julgamento: 05/05/2011 Órgão Julgador: Tribunal Pleno.
} 
Trata-se da já citada ADI 3.105, que teve por objeto o exame da constitucionalidade da Emenda Constitucional $n^{\circ}$ 41, que estabeleceu contribuição previdenciária sobre benefícios percebidos por servidores inativos e pensionistas da União, Estados, Distrito Federal e dos Municípios. Se antes da emenda as contribuições sociais incidiam tão-somente nas remunerações dos servidores ativos, após a sua promulgação, também os inativos passaram a sofrer a incidência da tributação. Esta emenda teve sua constitucionalidade contestada sob diversos prismas. Apesar de o tribunal ter julgado a contribuição dos inativos constitucional, que era a questão principal, ele julgou inconstitucional a discriminação entre aposentados e pensionistas que preencheram os requisitos para os benefícios após a edição da emenda e aqueles que já adquiriram o direito antes da emenda (aqueles que adquiriram direitos antes da emenda teriam faixas de imunidade menores, portanto pagariam mais tributos). Ademais, foi julgado inconstitucional a diferenciação entre os servidores da União e os servidores dos demais entes federativos quanto à definição de bases de cálculo distintas para cada um deles. Enquanto os servidores da União estavam imunes em $60 \%$ do valor dos proventos e pensões, os servidores dos demais entes tinham a imunidade de $50 \%$. No caso destas diferenças, apenas aqueles que adquiriram o direito aos benefícios após a emenda estariam incluídos.

Em sua decisão, o Tribunal declarou inconstitucionais as diferenciações acima, tanto aquela relativa ao momento em que se adquiriu o direito aos proventos e às pensões, quanto aquela relativa ao ente a que se submetem os servidores. Em sua decisão, o tribunal realizou uma equiparação por ampliação no que concerne ao regime imputado àqueles que completaram os requisitos antes da emenda. Contudo, no que se refere à distinção entre os servidores da União e dos demais entes, houve uma sentença de desconstrução, haja vista que foi declarado inconstitucional não só a imunidade no patamar de $60 \%$, quanto a imunidade ao nível de $50 \%$. Ou seja, não aumentou a faixa de imunidade dos servidores dos estados e municípios, nem reduziu a imunidade dos servidores da União. Eliminou ambas. 


\subsection{MOdelo Unilateral}

\subsubsection{Características}

Por unilateral deve-se entender o método reparatório que conta com a participação de apenas um dos poderes da república, no caso, o poder judiciário. Nesse sentido, o modelo unilateral de reparação das violações à igualdade constitucional, consoante o próprio nome indica, diz respeito ao padrão decisório em que o órgão de jurisdição constitucional efetua, de modo direto e com mão própria, o restabelecimento da igualdade.

Como se vê, o modelo ora designado unilateral nada mais representa senão a via comum de controle de constitucionalidade, que é vista como uma atividade estatal "inerente" aos órgãos do poder judiciário ${ }^{166}$. Afinal, a competência para controlar atos legislativos é atribuída ao poder judiciário como decorrência da sua consagrada prerrogativa de aplicar o Direito, sendo sua função garantir a precedência da Constituição em face da legislação ordinária, inclusive afastando a incidência daquelas normas contrárias à Constituição. Nesse sentido, pode-se afirmar que o modelo reparatório unilateral deflui da própria função judicial de garantia da supremacia da Constituição ${ }^{167}$, estando alicerçado na superioridade das normas constitucionais e na função judicial de controle de constitucionalidade das leis.

É, portanto, fundado em sua missão constitucional de guarda da Constituição que o poder judiciário brasileiro, especialmente seu órgão de cúpula, o Supremo Tribunal Federal, pratica uma jurisdição constitucional da igualdade de arquitetura variada, tal como observado no tópico anterior. Ampliações e reduções, de direitos e de obrigações, são conduzidas pela aplicação da igualdade.

No modelo unilateral, o iter metodológico tem a seguinte sequencia. Primeiramente, identifica-se a contrariedade ao direito de igualdade. Nesta etapa, o órgão judicial examina se há equiparação de desiguais, ou diferenciação de iguais, situações estas que consubstanciam lesões à igualdade constitucional. Para isso, analisa,

\footnotetext{
${ }^{166}$ Sobre o papel judiciário de intérprete final da Constituição, afirma Rui Barbosa: "o tribunal é apenas o instrumento da lei preponderante. Os maiores jurisconsultos e os maiores publicistas designam no Poder Judiciário o árbitro supremo, o intérprete final da Constituição". Cf. Atos inconstitucionais, p. 58.

${ }^{167}$ Nas palavras de Markus González Beilfuss, "la función de garante de la supremacía constitucional que tiene encomendada el Tribunal Constitucional exige que se ponga fin a la misma y se restablezca la igualdad". Cf.
} 
ainda que intuitiva e implicitamente, se há correlação lógica entre os elementos estruturais da igualdade (sujeitos, fator de comparação, finalidade), se há respeito à igualdade inata de todos, bem como se há justa proporção na atribuição de benefícios e sacrifícios entre os regimes e sujeitos comparados. Uma vez verificada uma violação à igualdade constitucional, adentra-se na etapa reparatória.

$\mathrm{Na}$ tarefa de restaurar o estado de constitucionalidade, o poder judiciário utiliza-se do remédio que lhe foi tradicional e constitucionalmente concedido. Trata-se da citada competência para reconhecer e eliminar preceitos incompatíveis com igualdade. Assim, verificado o desacordo de regimes jurídicos com a Constituição, o órgão judicial tem a seu lado a eficaz e peremptória prerrogativa de declarar a inconstitucionalidade de atos normativos, imputando-lhes a sanção de nulidade.

Em muitos casos, esta sanção é plenamente apta a restaurar a igualdade, bastando uma sentença simples que fulmine de nulidade preceito que, por si só, tenha gerado excesso ou restrição inconciliável com a igualdade constitucional. São os casos em que a violação é expressamente causada por uma inovação legal, cuja supressão basta para fazer ressurgir a igualdade no ordenamento. Entretanto, existem situações em que, mais do que sancionar de nulidade um dado dispositivo, é necessário reconstruir o direito infraconstitucional, remodelando-o no sentido de adequá-lo aos ditames da igualdade constitucional. A técnica decisória apta a promover essa transformação foi desenvolvida anteriormente, ao se analisar a chamada sentença manipulativa ${ }^{168}$, oportunidade em que se examinou a tipologia decisória costumeiramente utilizada pela jurisdição constitucional da igualdade.

Contudo, apesar de esboçados os fundamentos da tutela judicial, dentre eles a decisão de conteúdo manipulativo, ainda não se investigou se essas decisões são adequadas ao modelo brasileiro de jurisdição constitucional, ou mesmo quais as condições que, uma vez presentes, justificam a prolação de uma sentença que vai além da sua típica função de legislador negativo e atua no sentido de corrigir a legislação em vigor. Nesse sentido, é de se questionar até que ponto esta espécie decisória enquadra-se dentro dos limites da consagrada função judicial de garantia da Constituição,

\footnotetext{
${ }^{168}$ Essa hipótese enseja um acalentado debate. Sobre o assunto, Rui Medeiros, por exemplo, afirma: "quanto às relações entre o poder jurisdicional e o poder legislativo, as decisões modificativas trazem para a ribalta o problema da admissibilidade de uma função jurisdicional paralegislativa e substitutiva daquela que cabe constitucionalmente ao legislador”. Cf. A decisão de inconstitucionalidade, p. 477.
} 
configurando meio legítimo e eficaz para se reparar violações à igualdade constitucional.

Posto isso, compreende-se a razão de ser do estudo sobre a competência judicial. Afinal, quais são os casos cuja solução pode ser dada direta e exclusivamente pelo intérprete judicial? Para se responder a este questionamento, é necessário levar em consideração diversos bens constitucionais: tanto aqueles que garantem o direito de igualdade, já amplamente analisados, quanto aqueles que delimitam o exercício das funções estatais (separação de poderes), o que é feito neste momento. Em suma, é hora de se examinar a concretização do direito de igualdade à luz das funções judiciais e legislativas, o que explica as referências aos chamados limites funcionais da atividade reparatória de violações à igualdade constitucional.

Nesta missão, analisa-se tanto a potencialidade reformadora do modelo unilateral, quanto os limites que demarcam a função judicial. Em suma, investiga-se a admissibilidade do controle judicial direto. Após esse estudo, será possível elencar os requisitos que ensejam a utilização do modelo unilateral.

\subsubsection{Admissibilidade}

O modelo reparador judicial descrito acima enfrenta profundos dilemas de adequação no quadro constitucional da separação de poderes. Isso não decorre, propriamente, de um questionamento da função judicial em si, mas sim dos seus limites, especialmente quando se faz necessária a utilização de decisões manipulativas que, como visto, vão além da mera eliminação de um enunciado prescritivo e realizam uma reconstrução do ordenamento ${ }^{169}$. Esta segunda etapa não é indene de questionamentos. Muito pelo contrário, ela provoca grandes discussões no âmbito da jurisdição constitucional, sendo um importante capítulo dos estudos sobre ativismo judicial ${ }^{170}$.

Em suma, a grande questão que baliza o estudo da admissibilidade do modelo unilateral diz respeito à possibilidade, ou não, de o órgão judicial impor aos

\footnotetext{
${ }^{169}$ Na visão de Rui Medeiros, "se é indiscutível que a parte ablativa da decisão dispõe da eficácia própria das decisões de inconstitucionalidade em geral, outro tanto não se pode dizer em relação à parte reconstrutiva da decisão". Cf. A decisão de inconstitucionalidade, p. 478.

${ }^{170}$ Prova disso é a discussão feita por Elival da Silva Ramos acerca das sentenças manipulativas em sua tese sobre o ativismo judicial. Cf. Ativismo judicial, p. 209 e ss.
} 
demais poderes e órgãos operadores do direito uma nova conformação normativa, resultado de uma atividade integrativa realizada, em grande medida, para adequar a legislação infraconstitucional aos ditames do direito de igualdade. Assim, discute-se até que ponto o órgão judicial é competente para corrigir regimes jurídicos segundo normas constitucionais de conteúdo abrangente, como é o direito de igualdade ${ }^{171}$.

$\mathrm{O}$ primeiro aspecto a ser trabalhado diz respeito à natureza da atividade reconstrutiva efetuada pela jurisdição constitucional. Afinal, é preciso avaliar se essa atividade possui sólidos fundamentos de teoria jurídica, ou se afluem de posições subjetivistas e voluntaristas dos intérpretes da Constituição.

De modo geral, pode-se dizer que a atuação reconstrutiva com fundamento na igualdade possui lastro no dogma da completude do ordenamento jurídico ${ }^{172}$, o qual fundamenta a atividade judicial de preenchimento de lacunas jurídicas. Trata-se, aqui, de um elemento positivista que, na intenção de vedar o non liquet e a utilização de fontes não estatais do Direito, firmou o dogma estruturante de que inexistem espaços jurídicos $\operatorname{vazios}^{173}$. Com base nisso, justifica-se (ainda que não expressamente) a atividade judicial de reconfiguração de regimes reputados inconstitucionais.

\footnotetext{
171 A admissibilidade de controle de constitucionalidade pautado em normas abertas de caráter principiológico já é debatida desde o seu início, ao menos no ambiente europeu. Prova disso é a seguinte análise de Hans Kelsen: "É precisamente nesse fato de que a consideração ou a realização desses princípios - a que não se pode até hoje, a despeito de todos os esforços envidados nesse sentido, dar uma determinação um tanto unívoca que seja - não têm nem podem ter, no processo de criação do direito, pelos motivos precedentemente indicados, o caráter de uma aplicação do direito no sentido técnico, que encontramos respostas à questão de saber se eles podem ser aplicados por uma jurisdição constitucional. E é só aparentemente que não é assim, quando, como às vezes acontece, a própria Constituição se refere a esses princípios invocando os ideais de equidade, justiça, liberdade, igualdade, moralidade, etc., sem esclarecer nem um pouco o que se deve entender por isso. Se essas fórmulas não encerram nada mais que a ideologia política corrente, com que toda ordem jurídica se esforça por se paramentar, a delegação da equidade, da liberdade, da justiça, da moralidade, etc. significa unicamente, na falta de uma precisão desses valores, que tanto o legislador como os órgãos de execução da lei são autorizados a preencher de forma discricionária o domínio que lhes é confiado pela Constituição e pela lei”. Cf. Jurisdição constitucional, p. 168.

${ }^{172}$ Eis a definição de completude feita por Norberto Bobbio: "Por 'completude' entende-se a propriedade pela qual um ordenamento jurídico tem uma norma para regular cada caso. Tendo em vista que a ausência de uma norma costuma ser chamada de 'lacuna' (em um dos sentidos do termo 'lacuna'), 'completude' significa 'ausência' de lacunas. Em outras palavras, um ordenamento é completo quando o juiz pode encontrar nele uma norma para regular cada caso que se lhe apresente, ou melhor, não há caso que não possa ser regulado com uma norma extraída do sistema”. Cf. Teoria geral do direito, p. 259.

${ }^{173}$ Mais uma vez, cite-se Norberto Bobbio: "Diante do problema da completude, se consideramos um certo tipo de ordenamento jurídico, como o nosso, caracterizado pelo princípio de que o juiz deve julgar cada caso mediante uma norma pertencente ao sistema, a completude é mais que uma exigência, é uma necessidade, ou seja, é uma condição necessária para o bom funcionamento do sistema". Cf. Teoria geral do direito, p. 261.
} 
Em se tratando de um vício de inconstitucionalidade por violação ao direito de igualdade, a integração do direito configura, por assim dizer, um convite sedutor e de natural aplicação, em especial quando se trata de uma diferenciação inconstitucional. A razão disso é que, por conta da sua natureza tripolar, já amplamente estudada, a atividade jurisdicional com parâmetro na igualdade segue uma racionalidade comparativa. Desse modo, uma vez constatada a inadequação da relação internormativa, por haver uma diferenciação entre ambas, torna-se atraente ao espírito a equalização dos regimes via decisão judicial que remodele um dos regimes, colocando-o no mesmo patamar do regime em comparação. Para isso, bastaria uma integração normativa com o recurso da analogia.

Do mesmo modo, a inconstitucionalidade decorrente de uma equiparação de desiguais também poderia atrair uma decisão integrativa, ainda que num viés menos evidente. Afinal, mesmo quando se trata de diferenciar regimes em nome da igualdade, existirá a possibilidade de o órgão judicial promover, ao mesmo tempo, a diferenciação com relação a um regime e a subsequente aproximação com relação a outro regime jurídico. Enfim, também no caso das decisões de diferenciação, surge a integração normativa como uma possibilidade sedutora para a jurisdição constitucional.

Nada obstante as construções teóricas acerca da integração do direito, a igualdade constitucional envolve peculiaridades que devem ser levadas em consideração e que, se por um lado não contradizem o dogma da completude do ordenamento, por outro lado cria nuances que exigem um estudo especializado.

A primeira das peculiaridades diz respeito ao fato de que as lacunas normativas decorrem, no âmbito da jurisdição constitucional da igualdade, da própria decisão judicial. É o que se constatou anteriormente, quando se dividiu as sentenças manipulativas em duas partes: uma ablativa e uma reconstrutiva. Como o próprio nome indica, é exatamente a citada componente ablativa que gera uma lacuna jurídica. Em outras palavras, o vazio normativo não é obra (ou não-obra) do legislador, a qual deve ser operacionalizada pelo aplicador segundo as regras estruturais que indicam caminhos para se colmatar a lacuna, mas sim do próprio julgador. A consequência disso é que, com a operação reconstrutiva imediata, não se dá oportunidade aos tribunais de vivenciar e aplicar a normatividade lacunosa: a solução é imposta assim que revelado o problema. 
Outra peculiaridade relevante concerne à possibilidade de se utilizar o instrumento da integração normativa como instrumento para a remodelagem ideológica do direito, atuação esta que representa, no fundo, a atividade de legislar. Sobre o assunto, particular é o estudo das chamadas lacunas ideológicas (também chamadas impróprias), que se distinguem das lacunas jurídicas (próprias) à medida que correspondem não à ausência de uma norma, ou de um critério válido para decidir qual norma aplicar, mas sim à ausência de uma norma justa ${ }^{174}$.

Como se vê, as lacunas ideológicas não se referem a um ordenamento real, mas sim a um ordenamento ideal. Por isso, sua metodologia não é passível de ser utilizada em sistemas normativos fundados no monopólio estatal da criação jurídica, como é o caso brasileiro, sob pena de se permitir ao intérprete e aplicador do direito a transformação do ordenamento segundo suas opções políticas pessoais. Como afirma Norberto Bobbio, as lacunas impróprias só podem ser completadas pelo legislador ${ }^{175}$. No mesmo sentido, Karl Engisch assevera que uma lacuna político-jurídica (imprópria) apenas pode motivar o poder legislativo a uma reforma do Direito, mas não o juiz a seu preenchimento $^{176}$.

Aplicando-se tais entendimentos sobre as lacunas próprias e impróprias ao direito de igualdade, nota-se que a admissibilidade da intervenção judicial direta está condicionada à existência de uma lacuna jurídica não intencional, passível de complementação pelo direito vigente. Ou seja, não se deve reformar um regime jurídico por considerá-lo injusto, mas sim porque o vazio normativo pode ser preenchido por analogia com outro regime, em nome da igualdade.

Assim, é necessário diferenciar as hipóteses em que o direito de igualdade realmente se aplica enquanto direito positivo dotado de imperatividade por consagração constitucional, daquelas em que se aplica o juízo de equidade do julgador, que

\footnotetext{
${ }^{174}$ Cite-se, mais uma vez, a lição de Norberto Bobbio: “também se entende por 'lacuna' a ausência não de uma solução satisfatória, ou, em outras palavras, não a ausência de uma norma, mas a ausência de uma norma justa, ou seja, daquela norma que gostaríamos que existisse, mas não existe. Como essas lacunas derivam não da consideração do ordenamento jurídico como ele é, mas do confronto entre o ordenamento jurídico como ele é e como deveria ser, foram chamadas 'ideológicas', para dinstingui-las daquelas que fossem eventualmente encontradas no ordenamento jurídico como é, e que podem ser chamadas de 'reais'. Podemos também enunciar a diferença do seguinte modo: as lacunas ideológicas são de iure condendo; as lacunas reais são de iure condito". Cf. Teoria geral do direito, p. 281.

${ }^{175} \mathrm{Cf}$. Teoria geral do direito, p. 284 .

${ }^{176} \mathrm{Cf}$. Introdução ao pensamento jurídico, $10^{\mathrm{a}}$ ed. Lisboa: Fundação Galouste Gulbenkian, 2008, p. 282.
} 
considera injusto determinado regime, seja por atribuir mais direitos/obrigações do que deveria ou por ficar aquém do ideal ${ }^{177}$. A diferença entre tais raciocínios é tênue, porém não deve ser olvidado, sob pena de se transformar a igualdade numa porta de entrada para o jusnaturalismo subjetivista ${ }^{178}$.

Em acréscimo aos paradigmas da integração do direito, destaca-se o princípio democrático como diretriz geral para o processo de criação normativa e, portanto, de colmatagem de lacunas político-jurídicas. Tal processo, como se sabe, tem por substrato a ideia de soberania do povo, que exerce o poder por meio de seus representantes eleitos ou diretamente ${ }^{179}$.

A crítica decorrente do princípio democrático revela-se na impropriedade do desempenho, por parte de órgãos judiciais, de um papel conformador e/ou concretizador originário do ordenamento, papel este que avulta quando se trata de remodelar sentidos normativos para adequá-los ao direito de igualdade, cujas propriedades normativas denotam uma multiplicidade de possibilidades concretizadoras.

Em outras palavras, a competência reparatória unilateral encontra limites na própria natureza da sua função judicial, que não se confunde com a função legislativa. Enquanto a primeira é exercida de modo repressivo e negativo, a segunda é propositiva e conformadora. Em termos de jurisdição constitucional da igualdade, essa distinção funcional pode ser traduzida na competência legislativa para concretizar o direito, avaliando e definindo a lógica estrutural e a justa proporção na atribuição de direitos e obrigações, bem como na competência judicial para cassar relações normativas incompatíveis com a Constituição, retirando-as do ordenamento.

\footnotetext{
${ }^{177}$ Evitar o recurso à equidade é uma das finalidades do dogma da completude do direito. Nas palavras de Norberto Bobbio: "o dogma da completude, ou seja, o princípio de que o ordenamento jurídico seja completo para fornecer ao juiz uma solução para cada caso sem recorrer à equidade, foi dominante, e em parte o é até hoje, na teoria jurídica continental, de origem romanística". Cf. Teoria geral do direito, p. 263.

${ }^{178}$ É preciso, pois, evitar o perigo atentado por Ricardo Guastini: “não sendo os órgãos de aplicação investidos de poder normativo, a criação jurisprudencial de direito é pudicamente ocultada em hábitos mais discretos, e apresentada como explicitação de normas implícitas, ou seja, como elaboração de normas que se supõem já existentes, ainda que em estado latente, no sistema legislativo". Cf. Das fontes às normas, São Paulo: Quartier Latin, 2005, p. 231.

${ }^{179}$ Vale citar as palavras de Rui Medeiros sobre o tema: "o princípio democrático postula, por seu lado, que a decisão política seja tomada, diretamente ou através de órgãos representativos politicamente responsáveis, pelo povo. A negação ou atenuação da separação entre legislação e jurisdição põe, inevitavelmente, em causa o próprio modelo democrático-representativo vigente". Cf. A decisão de inconstitucionalidade, p. 495.
} 
Em se tratando de uma competência negativa, típica de um controle externo, o poder judiciário detém o poder de anular atos legislativos contrários à Constituição ${ }^{180}$. Entretanto, isso não implica na prerrogativa de atuar como se fosse o legislador, substituindo-o para inovar no ordenamento jurídico ${ }^{181}$. O poder judiciário não possui competência, enfim, para atuar como legislador positivo, criando normas ex nihil, mas apenas e tão somente para aplicar a Constituição, anulando leis contrárias à esta ${ }^{182}$.

Não é por outra razão que, em determinadas situações, o poder judiciário reconhece a existência de um limite intransponível para sua atuação e se autocontém, resignando-se a constatar uma inconstitucionalidade, mas deixando de repará-la porque não tem competência para tanto. Trata-se aqui da jurisprudência conhecida como selfrestraint, caracterizada pela opção por se manter uma inconstitucionalidade material sob o argumento de não se cometer uma inconstitucionalidade formal: para não se violar a separação de poderes, conserva-se a violação à igualdade.

Com base no argumento supra, o Supremo Tribunal Federal frequentemente assevera sua incompetência para alterar o regime normativo no sentido de restaurar o estado constitucional de igualdade. Em geral, esse modelo de decisão é utilizado quando se pleiteia a extensão de um benefício em nome da igualdade, como ocorreu no RE $402.748^{183}$; RE 595.653 ${ }^{184}$; RE $638.428^{185}$; RE $336.134^{186}$ entre outros. Tais acórdãos se

\footnotetext{
${ }^{180}$ Sobre a necessidade de um controle externo do parlamento, exercido em nome da Constituição, afirma Hans Kelsen: "Portanto não é com o próprio Parlamento que podemos contar para efetuar sua subordinação à Constituição. É um órgão diferente dele, independente dele e, por conseguinte, também de qualquer outra autoridade estatal, que deve ser encarregado da anulação de seus atos inconstitucionais isto é, uma jurisdição ou um tribunal constitucional". Cf. Jurisdição constitucional, p. 150.

${ }^{181} \mathrm{Na}$ mesma esteira, assevera Rui Medeiros: "A ideia fundamental é a de que ao juiz constitucional só compete averiguar se a lei é ou não contrária à Constituição, mas não lhe compete substituir-se ao legislador na formulação das soluções conformes à Constituição". Cf. A decisão de inconstitucionalidade, p. 495.

${ }^{182}$ Vale citar, mais uma vez, Hans Kelsen: "A anulação de uma lei se produz essencialmente como aplicação das normas da Constituição. A livre criação que caracteriza a legislação está aqui quase completamente ausente. Enquanto o legislador só está preso pela Constituição no que concerne a seu procedimento - e, de forma totalmente excepcional, no que concerne ao conteúdo das leis que deve editar, e mesmo assim, apenas por princípios ou diretivas gerais -, a atividade do legislador negativo, da jurisdição constitucional, é absolutamente determinada pela Constituição. E é precisamente nisso que sua função se parece com a de qualquer outro tribunal em geral: ela é principalmente aplicação e somente em pequena medida criação do direito. É, por conseguinte, efetivamente jurisdicional’. Cf. Jurisdição constitucional, p. 153.

${ }^{183}$ RE 402748 AgR / PE; Relator(a): Min. EROS GRAU; Julgamento: 22/04/2008; Órgão Julgador: Segunda Turma.

${ }^{184}$ RE 595653 AgR / RN; Relator(a): Min. DIAS TOFFOLI; Julgamento: 04/10/2011; Órgão Julgador: Primeira Turma.

${ }^{185}$ RE 638428 AgR / PB; Relator(a): Min. LUIZ FUX; Julgamento: 20/09/2011; Órgão Julgador: Primeira Turma.
} 
coadunam ao enunciado 339 da súmula de jurisprudência predominante do Supremo Tribunal Federal: "não cabe ao poder judiciário, que não tem função legislativa, aumentar vencimentos de servidores públicos sob fundamento de isonomia".

Embora este modelo mereça críticas por manter uma violação substancial (em relação à igualdade constitucional) em nome do respeito a preceitos procedimentais (divisão de funções entre os poderes), ao invés de buscar uma solução compatível com as regras constitucionais substantivas e formais, é preciso reconhecer que o modelo da autocontenção traz à tona um problema relevante para o estudo da reparação das violações à igualdade constitucional, qual seja, o dos limites do poder jurisdicional.

No intuito de se objetivar os parâmetros que legitimam a atuação judicial unilateral, o trabalho volta-se para a definição dos requisitos que, uma vez presentes, autorizam a intervenção judicial direta na reparação de violações à igualdade constitucional (modelo unilateral).

\subsubsection{Requisitos}

Para que o modelo unilateral possa ser efetivado dentro dos limites institucionais postos pela Constituição, é imprescindível que o poder judiciário observe algumas condições, as quais indicarão a possibilidade ou não de uma atuação judicial direta e unilateral. O detalhamento de tais requisitos se justifica pela seguinte razão: se por um lado o modelo unilateral não pode ser visto como apanágio para toda e qualquer violação ao direito de igualdade, portando-se o poder judiciário como o senhor absoluto da concretização deste direito, por outro lado também não se deve perder de vista que existem circunstâncias em que o órgão judicial encontra-se legitimado a restaurar o estado de constitucionalidade e assim o deve fazer, em nome da supremacia da Constituição.

A primeira das condições necessárias para a restauração unilateral é a existência de uma relação de igualdade constitucionalmente bem definida. Vale dizer, para que o órgão judicial seja legitimado a restaurar a igualdade, é necessário que a Constituição determine, com elementos suficientes, uma determinada relação de

\footnotetext{
${ }^{186}$ RE 336134 / RS; Relator(a): Min. ILMAR GALVÃO; Julgamento: 20/11/2002; Órgão Julgador: Tribunal Pleno.
} 
igualdade, qual seja, uma equiparação/diferenciação de dois sujeitos em função de um critério lógico e uma finalidade específica. Em suma: não deve existir espaço de livre apreciação e concretização por parte do legislador, mas sim uma predeterminação constitucional do equilíbrio necessário entre dois sujeitos.

As predeterminações constitucionais da igualdade podem decorrer de duas situações distintas.

A primeira delas refere-se à determinação constitucional de uma dimensão específica da igualdade, ou seja, de uma relação de igualdade como sendo necessariamente paritária ou necessariamente proporcional. Nesse contexto, será legítima a reparação unilateral para os casos de positivação de regimes jurídicos desiguais para situações em que a igualdade deve ser aplicada na sua dimensão paritária, assim como será legítima a reparação unilateral de regimes equiparados para sujeitos que a Constituição considera dignos de tratamento desigualmente proporcional. Em todos esses casos, contudo, a admissibilidade da reparação unilateral ficará restrita à declaração de inconstitucionalidade por sentenças simples, não cabendo ao poder judiciário ir além da sanção de nulidade e definir o nível de paridade ou o volume das porções a serem proporcionalmente atribuídas.

A segunda situação de predefinição constitucional está diretamente vinculado ao texto constitucional e, portanto, às formas como ele trata da igualdade. De fato, a Constituição brasileira não se limita a estabelecer uma cláusula geral (e aberta) do direito de igualdade, cláusula esta que remete à igualdade como uma norma estruturante (metanorma) do ordenamento jurídico. No que tange a determinados sujeitos e critérios, a Constituição define relações de igualdade mais precisas. Exemplo disso é o $\S 5^{\circ}$ do artigo 226 da Constituição, que estabelece: “os direitos e deveres referentes à sociedade conjugal são exercidos igualmente pelo homem e pela mulher". Ou seja, em se tratando de sociedade conjugal (finalidade), a aplicação do critério de gênero (fator de comparação) leva a uma situação de igualdade paritária entre homens e mulheres. Como se vê, o constituinte definiu com clareza uma relação de igualdade, concretizando a cláusula geral de igualdade.

Outros exemplos poderiam ser extraídos da Constituição, como a necessidade de tratamento paritário com relação a portadores de necessidades especiais nas relações de trabalho, haja vista que a Constituição baniu a utilização deste critério 
na atribuição de salários e critérios de admissão (art. $7^{\circ}$, inc. XXXI). Ou ainda a vedação de tratamento tributário diferenciado em razão da ocupação profissional ou função exercida (artigo 150, inciso II, da Constituição), preceito este que interdita a possibilidade de que o critério da ocupação profissional seja utilizado para fins de qualificar a relação tributária, apesar do fato de que, indiretamente, haver relação, pois ocupações profissionais que propiciam mais renda receberão cargas tributárias maiores. No entanto, isso ocorrerá pelo critério da capacidade contributiva, e não pelo critério da ocupação ou função profissional.

Em termos gerais, pode-se dizer que a via unilateral será considerada o modelo reparatório adequado quando a norma-parâmetro constitucional apresentar-se como uma relação de igualdade consolidada, ou seja, como uma norma que, densa em seu sentido prescritivo e completa em sua estrutura, define uma relação de igualdade específica que não requer atividade concretizadora e, portanto, tem condições de avalizar uma solução judicial constitucionalmente necessária ${ }^{187}$. Em outras palavras, a reparação unilateral, diretamente produzida pelo órgão de jurisdição constitucional, somente será considerada adequada quando a norma constitucional estabelecer a igualdade com precisão e, por não deixar espaço para a interposição legislativa, permitir a prolação de uma decisão judicial que reconstrua o sistema normativo de acordo com os parâmetros constitucionais ${ }^{188}$. É o que ocorre quando uma relação internormativa entra em conflito com uma regra de igualdade por ter diferenciado e/ou equiparado onde a Constituição havia feito o contrário de forma clara e definitiva. É nestas circunstâncias que os italianos afirmam ser a reparação judicial da igualdade uma solução a rime

\footnotetext{
${ }^{187}$ Cf. Rui Medeiros, A decisão de inconstitucionalidade, pp. 462-463.

${ }^{188}$ No mesmo sentido, Elival da Silva Ramos: "os marcos fronteiriços (tênues, reconheça-se) entre uma sentença manipulativa aditiva, respeitosa do ordenamento jurídico, e o ativismo judicial podem ser divisados em dois aspectos fundamentais: o princípio ou a norma constitucional especificamente justificante deve gozar de plenitude eficacial, sendo que a disciplina legislativa dele ou dela discrepante deve estar compreendida no seu campo de abrangência; de outra parte, o dispositivos ou o conjunto de dispositivos (regime jurídico) objeto da extensão reconstrutiva deve contar com uma textualidade que a ela dê suporte, vale dizer, que não a coloque, inequivocamente, fora do seu espaço de interpretação. É por isso que, desde a década passada, registra-se um relativo consenso doutrinário "em torno da ideia, segundo a qual, as sentenças aditivas ou são constitucionalmente obrigatórias, ou são juridicamente ilegítimas". Esse consenso se reflete no "entendimento de que as operações correctivas e integrativas das sentenças aditivas não devem editar Direito novo para colmatar um vazio jurídico, mas sim recorre a normas jurídicas já constantes do ordenamento', porquanto 'se o tribunal inventa uma disciplina que não existe, viola claramente o campo reservado ao legislador e a decisão aditiva é inválida”. Cf. Ativismo judicial: parâmetros dogmáticos, p. 220.
} 
obbligate $^{189}$, ou seja, resultado necessário da mera aplicação da norma constitucional e, portanto, legítima ${ }^{190}$.

Outra condição imprescindível para que seja instaurado o modelo unilateral de reparação da igualdade constitucional é a suficiência da declaração de inconstitucionalidade de um preceito positivado para que seja restaurada a constitucionalidade do sistema. Isto é, constitui requisito para a legitimidade da atuação judicial o isolamento, textual e lógico, do preceito responsável pela afronta ao direito de igualdade.

A ideia recém-exposta coaduna-se com as lições tiradas do estudo das sentenças simples. Com efeito, muitas violações ao direito de igualdade podem ser reparadas com a simples eliminação de um segmento normativo, à medida que ele seja responsável, por si só, pela inconstitucionalidade. Assim, se o excesso ou a insuficiência de um regime normativo for resultado de um preceito isolado que provocou um excesso ou uma restrição onde, anteriormente, vigorava um regime de alcance normativo compatível com a igualdade, será automática a restauração da igualdade após a declaração da nulidade do dispositivo lesivo ao direito de igualdade.

A sistemática aduzida, contudo, deve ser avaliada com cautela, em especial a questão de se tratar de uma inovação isolada no ordenamento jurídico. Vale repetir: a violação à igualdade deve decorrer da positivação de um novo regime que veio a alterar o equilíbrio anteriormente vigente. O motivo para essa preocupação é um só: se a sentença simples puder incidir sobre uma relação normativa qualquer, a eliminação de enunciados normativos poderia acarretar numa inadequada transformação completa do conteúdo normativo. Prova disso é a extirpação do vocábulo "não" de um dispositivo legal ${ }^{191}$. Nesta hipótese, apesar de se tratar de uma decisão limitada à declarar a

189 Segundo Rui Medeiros, neste caso a "nova norma funda-se numa disposição ou princípio constitucional vinculante". Cf. A decisão de inconstitucionalidade, p. 463.

${ }^{190}$ Mais uma vez, é válido citar a lição de Rui Medeiros: “A admissibilidade das decisões modificativas impõe-se, segundo outro critério, quando a modificação da lei operada pelo Tribunal Constitucional incorpora unicamente uma 'solução constitucionalmente obrigatória', pois, nestes casos, o Tribunal Constitucional não exerce manifestamente uma função substancialmente criativa ex nihil. (...) Temos para nós que, nos casos em que não exista uma pluralidade de soluções alternativas e em que, portanto, a solução adoptada seja constitucionalmente necessária, a decisão modificativa não ofende as prerrogativas do legislador". Cf. A decisão de inconstitucionalidade, p. 504.

${ }^{191}$ Rui Medeiros faz a mesma observação: "Efectivamente, uma decisão que, do ponto de vista formal, se apresente como uma decisão de inconstitucionalidade parcial, pode, do ponto de vista dos seus efeitos, constituir uma decisão modificativa. Basta, para isso, que a decisão de inconstitucionalidade parcial determine à partida uma alteração qualitativa do significado da lei. A simples eliminação de um não pode, 
nulidade de um preceito, haveria uma verdadeira transformação do sentido normativo e a sentença, aparentemente simples, incidiria na equivocada atuação como legislador positivo.

Como exemplos de situações que preenchem o requisito e habilitam a competência judicial unilateral estão aquelas em que dois sujeitos merecedores de tratamento paritário, numa determinada circunstância, vêm a ser diferenciados e um deles recebe um benefício ou um ônus que o coloca em situação mais ou menos privilegiada que o(s) sujeito(s) antes equiparado. Se essa diferenciação decorrer de uma nova lei que veio a criar o ilegítimo benefício/ônus, a sua extirpação do ordenamento mediante uma sentença declaratória simples como método de restauração da igualdade será admissível. Ao contrário, se a mesma relação não fosse objeto de regulação por norma qualquer e o legislador positivasse regimes diferenciados num mesmo contexto legislativo, não poderia o poder judiciário equipará-los, aumentando ou reduzindo o alcance de um dos regimes jurídicos, pois tal conduta representaria verdadeira transformação do significado da lei e, portanto, uma inadmissível substituição do legislador ${ }^{192}$.

Em última instância, o requisito acima visa preservar a deliberação legislativa como processo decisório consciente e racional, responsável por uma seleção de condutas (com diferenciações e equiparações) sistemática. Assim, um trabalho legislativo uniforme seria preservado enquanto tal, vedando-se manipulações judiciais unilaterais.

Neste contexto, não se pretende defender um engessamento da igualdade, como se regimes adequados não pudessem ser alvo de reformas legislativas hábeis a dar novos contornos à relação de igualdade. Do mesmo modo, não se pretende afirmar que as soluções para inovações legislativas inconstitucionais seja sempre retornar aos regimes anteriores, como se estes fossem os únicos compatíveis com a igualdade. $\mathrm{O}$ ponto aqui defendido é que, em se tratando de reparação unilateral, não poderá haver

por exemplo, sob a capa de uma operação aparentemente redutiva, introduzir novas normas no ordenamento". Cf. A decisão de inconstitucionalidade, p. 487.

192 A distinção detalhada é assim comentada por Rui Medeiros: “As decisões modificativas não se limitam, portanto, a suprimir uma norma, deixando-se gerar outras a partir das fontes de direito existentes (já sabemos que, neste sentido, todas as decisões jurisdicionais são criativas...). O seu objetivo é a transformação do significado da lei - a sua metamorfose - e não a simples eliminação de uma das partes que a compõem. A norma inconstitucional é, por força da manipulação do âmbito da decisão de inconstitucionalidade, substituída por uma nova norma, que não decorre das fontes anteriores. O Tribunal Constitucional actua, portanto, como legislador positivo". Cf. Decisão de inconstitucionalidade, p. 488. 
criação materialmente legislativa pelo poder judiciário, razão pela qual ele deverá optar entre a manutenção do regime inovador ou então o retorno ao regime anterior. Não poderá, enfim, transformar qualquer deles em regimes não deliberados pelo legislador. Afinal, caso seja esta a solução adequada, o poder judiciário deverá fazer uso do modelo bilateral, a seguir exposto.

O último dos requisitos para a intervenção judicial unilateral seria o maior respeito aos regimes gerais em face dos regimes especiais. Por este requisito, em tese não compete ao poder judiciário transformar um regime especial em regime geral, uma vez que tal atitude tem maior potencial lesivo ao supracitado princípio democrático. Trata-se aqui de um critério de sutil constatação, mas de importantes consequências. Suponha-se que, no âmbito de um regime normativo genérico e uniforme, um grupo limitado de sujeitos seja selecionado para receber um tratamento legal mais benéfico ou prejudicial. Suponha-se, ademais, que tal diferenciação seja incompatível com o direito de igualdade, que requer uma igualdade paritária (ou proporcional de iguais) entre os sujeitos. Neste caso, poderia o poder judiciário tornar regra o regime excepcional, estendendo o novo regime jurídico para todos aqueles que não foram selecionados para receber o benefício (ou o ônus)?

A resposta é que, como regra, deve ser evitada a transformação do regime especial em regimes geral, pelo simples fato de que tal conduta implicaria em usurpação da função legislativa com elevado grau de intensidade ${ }^{193}$. Nesse sentido também caminha o Supremo Tribunal Federal, que nos casos em que se contesta a constitucionalidade de benefícios fiscais concedidos a um grupo limitado, tende a afirmar que a extensão do benefício não é uma solução possível, mas apenas a declaração da inconstitucionalidade do regime privilegiado específico. Como exemplo, vale citar a decisão proferida no AI $808268 \mathrm{AgR} / \mathrm{RJ}^{194}$, na qual o tribunal afirmou que “em regra, a concessão inconstitucional de um benefício deve ser corrigida pela eliminação do incentivo inválido, de modo a restaurar a situação de igualdade entre as

\footnotetext{
${ }^{193}$ Este é o entendimento de Alfonso Celotto: "compiere tale operazione contraria - vale a dire, annullare la norma generale con transformazione della norma di specie in norma generale - configurerebbe, infatti, 'una vera e propria usurpazione di funzioni legislative da parte della Corte: conseguentemente, non si provvede a scrutinare l'eguaglianza nelle ipotesi in cui 'la disposizione assunta a tertium comparationis ha natura di norma eccezionale, derogatoria rispetto alla regola generale desumibile dal complessivo sistema normativo, non potendo certo esses estesa una norma di privilegio"'. Cf. Il controlo di eguaglianza sulle leggi in Italia, p. 13.

${ }^{194}$ AI 808268 AgR / RJ; Relator(a): Min. JOAQUIM BARBOSA; Julgamento: 27/03/2012; Órgão Julgador: Segunda Turma.
} 
partes que imotivadamente foram tratadas desigualmente". Apesar disso, reconheceu que, excepcionalmente, é possível solução diversa, quando afirma que “excepcionalmente, é teoricamente possível que a importância e a densidade do benefício justifiquem a manutenção do benefício e de sua aplicação para situações análogas, ainda que não idênticas".

Enunciados e explicados as principais condições habilitadoras da reparação judicial direta da igualdade, é hora de se examinar o modelo reparatório bilateral.

\subsection{Modelo Bilateral}

\subsubsection{Características}

Inicialmente, carece destacar que a bilateralidade ora indicada consiste na atuação conjunta de duas funções no processo de reparação das violações à igualdade constitucional: a função judiciária e a função legislativa ${ }^{195}$. Diferentemente do modelo unilateral, em que o órgão judicial promove, ele próprio, a reparação da afronta ao direito de igualdade, o modelo bilateral pauta-se na relação dialética instaurada entre dois poderes habilitados a concretizar a Constituição, quais sejam, o poder judiciário e o poder legislativo. Representa, em suma, um modelo que objetiva harmonizar a norma substantiva da igualdade constitucional com as regras procedimentais que estabelecem a divisão de competências entre os poderes e, especialmente, a tarefa legislativa de concretizar a Constituição ${ }^{196}$.

Antes de prosseguir, vale ressaltar que o modelo bilateral pode vir a envolver o poder executivo. Entretanto, essa atuação ocorrerá apenas à medida que este participe do processo legislativo ou, indiretamente, da direção da política na condição de chefia de governo. Assim, por se tratar de uma participação que não guarda correspondência, propriamente, com a atividade de executar normas gerais e abstratas

\footnotetext{
${ }^{195}$ A ideia, e a nomenclatura, foram extraídas das obras de Markus González Beilfuss (cf. Tribunal Constitucional y reparación de la discriminación normativa, pp. 178-181) e Rui Medeiros (A decisão de inconstitucionalidade), pp. 522-528.

196 De acordo com Rui Medeiros, esta solução "constitui um travão à tendência para a 'desresponsabilização do legislador', harmonizando-se, coerentemente, com a ideia de que, num Estado Democrático, cabe aos representantes do povo aprovar legislação conforme a Lei Fundamental”. Cf. A decisão de inconstitucionalidade, p. 523.
} 
(leis), optou-se por utilizar a nomenclatura bilateral e, oportunamente, fazer considerações sobre a participação do poder executivo. O que se quis destacar é antes a conjugação de funções do que de órgãos.

Os aspectos processuais desta relação entre poderes serão oportunamente estudados. Cabe aqui tracejar suas principais características institucionais.

Basicamente, o modelo bilateral tem a seguinte lógica. Uma vez submetida ao poder judiciário uma questão de inconstitucionalidade envolvendo o direito de igualdade, caberá o julgador analisar, primeiramente, se de fato há um vício na legislação infraconstitucional. Em caso positivo, o ordenamento jurídico terá que ser reparado. Neste passo, se preenchidos os requisitos legitimadores da decisão judicial diretamente reparadora, instala-se o modelo unilateral. Por outro lado, se estas condições não estiverem presentes, caberá ao órgão judicial suspender sua atuação e remeter a questão ao poder competente para a restauração, qual seja, o poder legislativo, que terá condições de reformar todo o arcabouço normativo questionado.

O modelo corretivo bilateral não é uma tese nova. Na verdade, encontra semelhanças em institutos estrangeiros, como a figura austríaca do diferimento da entrada em vigor da declaração de inconstitucionalidade, da experiência alemã das declarações de inconstitucionalidade sem nulidade e das sentenças aditivas de princípio italianas ${ }^{197}$. No Brasil, tem fundamento na divisão funcional das competências constitucionais e na modulação de efeitos pro futuro. Cada um a seu modo, todos esses mecanismos visam convocar o poder legislativo a solucionar o vício de inconstitucionalidade identificado, ofertando-lhe período de tempo certo para a tarefa e estabelecendo diretrizes consideradas imprescindíveis para a restauração do estado de constitucionalidade.

Como já se teve oportunidade de estudar ${ }^{198}$, a manipulação dos efeitos temporais constitui uma ferramenta importante para a jurisdição constitucional da igualdade. Ao permitir a suspensão da decisão judicial por um determinado período de tempo, a modulação de efeitos pro futuro evita soluções drásticas, como a eliminação de todo o arcabouço normativo questionado e o subsequente vazio normativo na matéria, e

${ }^{197}$ Cf. Markus González Beilfuss, Tribunal Constitucional y raparación de la discrimnación normativa, pp. 181-211.

${ }^{198}$ Tópico 2.4.3. 
abre oportunidade ao poder legislativo para cumprir sua missão constitucional ${ }^{199}$. Com isso, resguarda-se a função legislativa e a separação de poderes.

Dentre os fundamentos que autorizam este modelo, sobressai o papel do poder legislativo na avaliação e ponderação dos diversos elementos que envolvem o estabelecimento de relações internormativas equilibradas, segundo os ditames da igualdade constitucional. Com efeito, a igualdade é, ao menos na hipótese de cláusula geral, um direito que se resigna a determinar tratamentos equiparados para alguns casos e proporcionalmente diferenciados para outros, a depender dos sujeitos, critérios e finalidades envolvidos. Ou seja, não determina a exata medida de um direito ou obrigação, mas sim uma determinada relação que se deve ter com outros direitos e obrigações.

O que se pretende dizer é que o direito de igualdade, seja quando exige equivalência, seja quando exige diferenciação, não determina a medida exata em que essa equiparação ou essa diferença devem se dar. Em realidade, a determinação desta medida está no âmbito da liberdade de conformação do legislador, ao menos quando o parâmetro de controle é unicamente o direito de igualdade. Um exemplo, que envolve dimensões numéricas, pode deixar isto bem claro.

Uma vez entendido que dois sujeitos, de acordo com direito constitucional de igualdade, merecem tratamento paritário quanto a uma imunidade ou a uma isenção tributária, o legislador não pode oferecer tratamento diferenciado entre ambos. Assim, não pode oferecer imunidade de $60 \%$ para um e $50 \%$ para outro, pois o patamar deve ser o mesmo ${ }^{200}$. Diante desta circunstância, qual seria a solução que respeita a igualdade constitucional? Equipará-los em $50 \%$ ou em $60 \%$ ? A resposta é os dois, assim como haveria respeito à igualdade se ambos recebessem isenção/imunidade de 10\%, 27\%, $45 \%, 82 \%$, etc. Em suma, o importante é que o percentual seja o mesmo para os dois sujeitos. Por tudo isso, percebe-se que, embora o legislador tenha adotado uma diferença inconstitucional, restam inúmeras (para não dizer infinitas) hipóteses de

\footnotetext{
${ }^{199}$ No mesmo sentido, afirma Markus González Beilfuss: "Como es natural, este modelo innovador, que supera el tradicional aislamiento del Tribunal Constitucional respecto a las restantes instituciones del Estado, no sólo puede resultar útil en relación con los problemas funcionales del restablecimiento de la igualdad, sino que también puede evitar otros problemas del modelo tradicional del legislador negativo y en especial, las dificultades que en determinados supuestos acarrea el vacío normativo provocado por las sentencias estimatorias simples. De ahí que su desarrollo también se haya producido, como se verá, en este ámbito". Cf. Tribunal Constitucional y reparación de la discriminación normativa, p. 177.

${ }^{200}$ Essa distinção foi extraída com base na decisão proferida pelo Supremo Tribunal Federal na ADI 3.105 .
} 
legislação conforme a Constituição. E isto é uma consideração que merece respeito e deve pautar a construção de um modelo dialógico de reparação das violações à igualdade constitucional.

Por aí se vê que, no modelo bilateral, o órgão judicial se limita a declarar que certo regramento é contrário ao direito de igualdade, sem definir qual seria o tratamento condizente com a Constituição. É como se o julgador reconhecesse que, apesar de existirem múltiplas possibilidades de regulação compatíveis com a igualdade, o legislador escolheu, exatamente, uma incompatível.

Disso tudo se infere que a construção de um modelo bilateral fundamenta-se na constatação de que nem sempre a atuação unilateral do poder judiciário é legítima para restabelecer o estado de igualdade constitucional. Tendo em vista as propriedades normativas da igualdade, constata-se que, sendo a igualdade uma norma de sobreposição cuja satisfação pode tomar diversos formatos, frequentemente haverá um amplo espaço para o exercício da livre conformação normativa pelo legislador. Nesta situação, não competirá ao poder judiciário arvorar-se da autoridade de guardião da Constituição e impor sua interpretação do direito de igualdade como se fosse a única constitucionalmente adequada.

\subsubsection{Admissibilidade}

A admissibilidade do modelo bilateral é um tema que está na raiz do debate constitucional acerca não apenas dos limites do poder judiciário em si, mas também do papel do legislador na concretização das normas constitucionais. Encontra-se, portanto, intrinsecamente relacionado com o processo democrático de conformação dos valores subjacentes às normas constitucionais, processo este que se justifica na própria necessidade constitucional de complementação legislativa, seja esta requerida explicitamente (deveres de legislar), ou mesmo implicitamente (concreção de conceitos jurídicos indeterminados).

Como se sabe, na tarefa de concretização do direito, a relação entre a Constituição e a legislação possui características especiais que a diferencia da relação entre lei e ato administrativo, ou entre lei e decisão judicial. Diferentemente destas, que 
atuam no sentido de executar ${ }^{201}$ normas superiores, positivando sentidos normativos mais concretos e, muitas vezes, individualizados, a relação entre Constituição e Lei observa uma racionalidade distinta, antes política do que técnica ${ }^{202}$, o que indica a existência de contornos mais abrangentes e, portanto, de maior liberdade de ação para o legislador ${ }^{203}$.

Em se tratando do direito de igualdade, cuja estrutura envolve a acomodação de sujeitos, critérios e finalidades, cujo conteúdo normativo retrata as ideias fluidas de não discriminação e de equilíbrio na atribuição de bens, direitos e obrigações, sobressai o papel político do poder legislativo de avaliar circunstâncias fáticas diversas e sopesar finalidades constitucionais legítimas, de modo a concretizar relações de igualdade que satisfaçam a norma constitucional, variável ao longo do tempo e das concepções culturais de uma comunidade.

Os fundamentos para uma jurisdição constitucional atenta à função legislativa não constituem uma novidade no constitucionalismo, que vem se dedicando à temática com vigor. Os estudos referidos não dizem respeito, tão somente, às investigações que visam delinear os limites da competência judicial, constrangendo-o a remanescer dentro da sua função (self restraint), mas também os estudos voltados para a elucidação de métodos em que a jurisdição constitucional protege e impulsiona a atividade legislativa, sem substitui-la.

Nesse contexto, é significativa a teoria que postula a defesa judicial do procedimento democrático. Tal teoria parte do pressuposto de que é o procedimento democrático de tomada de decisões políticas o modo mais adequado de se reconhecer, e escolher, valores substantivos básicos da comunidade, e não a jurisdição constitucional. Por esta perspectiva, resguarda-se a democracia, atribuindo-se ao poder judiciário a

\footnotetext{
${ }^{201}$ Segundo J. J. Gomes Canotilho, "o pensamento de execução considera que, em termos gerais, a posição da lei relativamente à Constituição não é diferente da relação hierárquico-normativa entre a lei e o acto administrativo, executor da mesma". Cf. Constituição dirigente e vinculação do legislador, $p$. 216.

${ }^{202}$ No mesmo sentido, afirma Jose Julio Fernandez Rodriguez: "La peculiar relación que se establece entre el texto constitucional y el legislador no es descifrable simplemente desde una óptica jurídica que prescinda de lo político y que opere tan sólo con los esquemas del mecanismo de la ejecución de una ley de rango superior. La legislación, como ya tuvimos oportunidad de indicar más arriba, no es ejecución de la Constitución". Cf. La inconstitucionalidad por omisión. Teoria general. Derecho comparado. El caso español, Madri: Editorial civitas, 1998, p. 168.

${ }^{203}$ Em lapidar ensinamento, afirma Hans Kelsen: "A liberdade do legislador, que só está subordinado à Constituição, submete-se a limitações relativamente fracas; seu poder de criação permanece relativamente grande. A cada grau que se desce, a relação entre liberdade e limitação se modifica em favor do segundo termo: a parte da aplicação aumenta, a da livre criação diminui”. Cf. Jurisdição Constitucional, p. 126.
} 
tarefa de defesa e manutenção das regras do jogo democrático, como a garantia da lisura e correição de procedimentos eleitorais e legislativos, a proteção de direitos que permitam uma deliberação ampla e livre, o resguardo do processo de representação política, a abertura dos canais de participação popular, a proteção e a promoção da voz política das minorias, a manutenção do diálogo e da comunicação entre os diferentes grupos dentro da comunidade, entre outras ${ }^{204}$.

John Hart Ely é reconhecido como um dos fundadores da linha procedimental da jurisdição constitucional. Em síntese, o autor sustenta que a Constituição ${ }^{205}$ prevê antes cláusulas processuais e estruturais voltadas para a garantia da discussão pública e aberta de questões políticas, do que valores substantivos a serem desvendados por juízes constitucionais ${ }^{206}$. E, para o autor, esta posição merece respeito porque, numa democracia representativa, as determinações de valores devem ser feitas pelos representantes eleitos ${ }^{207}$, sendo inaceitável cogitar que há um conjunto objetivo de princípios morais a serem descobertos e aplicados por juízes ${ }^{208}$. O papel da justiça constitucional deve restringir-se, portanto, a reforçar a representação democrática (representation-reinforcing approach ${ }^{209}$ ), e, por tal razão, deve afastar-se de argumentos de filosofia política que fundamentem escolhas substantivas.

Também preocupado em solucionar problemas relativos à divisão de poderes e à dificuldade de se desenhar uma prática interpretativa que não subjugue as competências legislativas, Jürgen Habermas entende que a jurisdição constitucional deve referir-se prioritariamente às condições da gênese democrática das leis ${ }^{210}$, e não a

\footnotetext{
${ }^{204}$ Podem ser considerados adeptos dessa visão autores como John Hart Ely, Jürgen Habermas, Cass Sunstein, Jeremy Waldron, entre outros.

${ }^{205}$ Embora a referência seja a Constituição norte-americana, é razoável vislumbrar no procedimentalismo uma teoria de interpretação constitucional que vai além de especificidades constitucionais, porquanto a ideia subjacente a ela refere-se à missão de interpretar e "dizer o direito constitucional" enquanto carta política superior e fundamental. Trata-se, portanto, de uma teorização que objetiva atenuar o poder da justiça constitucional, destituindo-a do papel de interpretar os valores substanciais e fazer escolhas, também substanciais, com base nestes. Por tais motivos, verifica-se absolutamente adequado levá-la em consideração mesmo no contexto em que vivemos.

${ }^{206}$ Em suas palavras: "my claim is only that the original constitution was principally, indeed I would say overwhelming, dedicated to concerns of process and structure and not to the identification and preservation of specific substantive values". Cf. Democracy and distrust, Fourteenth printing. Cambridge: Harvard University Press, 2002, p. 92.

${ }^{207}$ Cf. Democracy and distrust, p. 103.

${ }^{208}$ Cf. Democracy and distrust, p. 54.

${ }^{209}$ Cf. Democracy and distrust, p. 102.

${ }^{210}$ Vale transcrever o conteúdo integral deste raciocínio: "o controle abstrato de normas deve referir-se, em primeira linha, às condições da gênese democrática das leis, iniciando pelas estruturas comunicativas de uma esfera pública legada pelos meios de massa, passando, a seguir, pelas chances reais de conseguir espaço para vozes desviantes e de reclamar efetivamente direitos de participação formalmente iguais,
} 
convicções éticas consuetudinárias. Isto é, a jurisdição constitucional deve resguardar as democracia $^{211}$, e não estabelecer unilateralmente conteúdos para normas constitucionais controvertidas. A razão disso, na visão do autor, é que "direitos não podem ser assimilados a valores", pois estes têm um sentido teleológico, enquanto aqueles são deontológicos ${ }^{212}$.

Outros autores, como Cass Sustein e Jeremy Waldron, poderiam ser citados como defensores de uma jurisdição constitucional atenta à função legislativa como elemento de democracia no estado constitucional. Não é objetivo deste trabalho, entretanto, enveredar para essa discussão, mas apenas ressaltá-la como arranjo teórico passível de sustentar a admissibilidade de um modelo bilateral de reparação das violações à igualdade constitucional. Mesmo porque, trata-se de um sistema que valoriza uma correlação entre o poder judiciário e o poder legislativo, à medida que a liberdade de conformação legislativa passa a ser objeto de resguardo e proteção da jurisdição constitucional.

Mas os pressupostos de admissibilidade do modelo reparatório não se resumem à guarida da missão legislativa de concretizar, democraticamente, a Constituição. Além da ideia de que a jurisdição constitucional não deve se comportar como legislador positivo, usurpando da competência constitucional do poder legislativo, também existe a preocupação com a radicalidade que pode ser gerada pela aplicação da sanção de nulidade sobre os regimes jurídicos violadores da igualdade, ainda que tal conduta seja perfeitamente compatível com a função de legislador negativo tradicionalmente desempenhada pelos órgãos judiciais. Trata-se, aqui, da aversão ao vazio normativo - horror vacui ${ }^{213}$.

chegando até à representação simétrica de todos os grupos relevantes, interesses e orientações axiológicas no nível das corporações parlamentares e atingindo a amplitude dos temas, argumentos e problemas, dos valores e interesses, que têm entrada nas deliberações parlamentares e que são levadas em conta na fundamentação das normas a serem decididas". Cf. Direito e democracia: entre facticidade e validade, vol. II. $2^{\mathrm{a}}$ ed. Trad. Flávio Beno Siebeneichler. Rio de Janeiro: Tempo Brasileiro, 2003, p. 327.

${ }^{211}$ Cf. Direito e democracia, vol. II, p. 326.

${ }^{212}$ Cf. Direito e democracia, vol. II, pp. 315-317.

${ }^{213}$ Tal preocupação é compartilhada, dentre outros, por Jorge Pereira da Silva: "o argumento da separação de poderes prova em demasia por uma outra razão, já que, levado até às suas últimas consequências, impediria o preenchimento de todas e quaisquer lacunas resultantes da destruição jurisdicional das obras do legislador, provocando, assim, até em sede de fiscalização da constitucionalidade por ação, uma verdadeira situação de horror vacui". Cf. Dever de legislar e proteção jurisdicional contra omissões legislativas: contributo para uma teoria da inconstitucionalidade por omissão, p. 237. 
Quando se analisam técnicas e efeitos do controle de constitucionalidade dos atos normativos, logo se verifica a radicalidade sobre a qual repousa a sanção de nulidade ex tunc de um preceito deliberado e aprovado pelo legislador. Além desta capacidade judicial configurar uma relação de superioridade do poder judiciário sobre o poder legislativo (o que é alvo de controvérsias seculares sobre o controle judicial das leis em $\left.\mathrm{si}^{214}\right)$, também implica numa instabilidade no ordenamento jurídico, haja vista a quebra do fundamento jurídico de incontáveis direitos e obrigações nascidos durante a vigência dos preceitos declarados inconstitucionais ${ }^{215}$. Por essa razão, sustenta-se que a nulidade pode vir a gerar, nalguns casos, situações de maior inconstitucionalidade ainda $^{216}$.

A problemática da sanção de nulidade e seus efeitos ex tunc, responsáveis pela criação de vazios normativos no ordenamento, há muito atormenta operadores do direito no Brasil e alhures. Isso fica nítido quando se verifica que, hodiernamente, a prática da jurisdição constitucional criou diversas soluções intermediárias entre a decisão de acolhimento da inconstitucionalidade (com nulidade ex tunc) e a decisão de rejeição do pedido declaratório de inconstitucionalidade, conjunto este designado, neste trabalho, como sentença manipulativa. Em grande medida, o que justifica toda essa maleabilidade é, justamente, a tentativa de atenuar efeitos perversos duma atuação judicial puramente negativa, com a criação de espaços não regulados ${ }^{217}$.

\footnotetext{
${ }^{214}$ A controvérsia é citada há tempos. Por todos, Alfredo Buzaid: "A verificação da constitucionalidade dos atos da legislatura e da administração assegurou a supremacia do Poder Judiciário. Esta posição de aparente desequilíbrio no sistema de harmonia e independência dos poderes inquietou certos publicistas, que perguntaram: se os atos dos demais poderes ficam sujeitos ao contrôle do Judiciário, quem julga os juízes? Quis judices judicabit?". Cf. A ação direta de declaração de inconstitucionalidade no direito brasileiro, p. 35.

${ }^{215}$ Hans Kelsen já alertava para o problema: "resulta da anulação, por assim dizer, um vazio jurídico. A matéria que era até então regulada deixa de sê-lo; obrigações jurídicas desaparecem; segue-se a liberdade jurídica. Poderão resultar daí consequências desagrabilíssimas. Sobretudo se a lei não foi anulada por causa do seu conteúdo, mas apenas por causa de um vício de forma qualquer que se produziu quando da sua elaboração, em particular quando a elaboração de uma lei para regular o mesmo objeto requer um prazo muito longo. Para remediar esse inconveniente, é bom prever a possibilidade de diferir a entrada em vigor da sentença de anulação até a expiração de certo prazo a contar da sua publicação". Cf. Jurisdição constitucional, p. 172.

${ }^{216}$ Rui Medeiros, ao tratar do constitucionalismo italiano, assevera: "Em Itália, recorde-se, o facto de o efeito caducatório das normas declaradas inconstitucionais se produzir ex tunc, com efeito imediato e retroactivo, tornava imanente o perigo de vazios normativos e, consequentemente, de situações de maior inconstitucionalidade". Cf. A decisão de inconstitucionalidade, p. 499.

${ }^{217}$ O fenômeno descrito é comentado por diversos autores. Na Itália, é possível citar Roberto Pinardi: "quel che preme, piuttosto, rilevare, a questo punto dell'indagine, è che in presenza di una lacuna 'reale' determinata dall'accoglimento della quaestio sub iudice, non facilmente e prevedibilmente colmabile, in tempi brevi, a causa della 'tradizionale, e mai sufficientemente deprecata, inerzia del legislatore', la rigida alternativa immaginata dai Costituienti tra pronunce di rigetto e mero acoglimento si è presto rivelata del
} 
Diante desse quadro, surge o modelo bilateral como aquele apto a evitar vazios normativos sem conduzir a jurisdição constitucional a um modelo de legislador paralelo $^{218}$. Assim, diante de inconstitucionalidade cuja declaração implique na criação de lacunas prejudiciais à segurança jurídica, o poder judiciário concede ao poder responsável pela inconstitucionalidade (o poder legislativo) um prazo para que o mesmo corrija a incompatibilidade, promulgando nova legislação a respeito ${ }^{219}$. Nesta ocasião, vale registrar, o legislador terá oportunidade de fazer uma ampla reforma dos regimes jurídicos em questão, mais abrangente e eficaz do que aquela eventualmente feita pelo poder judiciário, através de sentenças manipulativas. Isso porque a atividade legislativa desempenhada pelos parlamentos não é condicionado por limitações processuais típicas da atividade judicial.

Em suma, o modelo bilateral nada mais representa senão um meio termo entre o poder judiciário como legislador negativo categórico (rígido na aplicação da sanção de nulidade) e o poder judiciário como legislador positivo (maleável quanto ao conteúdo das normas impugnadas). No que tange ao direito de igualdade, o método se revela particularmente interessante, tendo em vista a natureza tripolar da relação de inconstitucionalidade, que invariavelmente envolve uma relação entre regimes jurídicos e, por isso, comumente requer uma solução que reconstrua uma complexa relação de direitos e obrigações, comparadas entre si. É por estas razões que o modelo bilateral se qualifica como um método de harmonização dos bens constitucionais preponderantes na jurisdição constitucional da igualdade ${ }^{220}$.

tutto insufficiente allo scopo di ottenere una reintegrazione adguata dell'ordinamento costituzionale violato"; cf. L'horror vacui nel giudizio sulle leggi, p. 66. No mesmo sentido, afirma Rui Medeiros: "As sentenças manipulativas, recorda sugestivamente Crisafulli, nasceram de uma exigência prática e não de abstractas lucubrações teóricas. Foi a preocupação em evitar que das decisões de inconstitucionalidade derivassem vazios no ordenamento - aliada à inércia do legislador em preenche-los - que levou a Corte Costituzionale a adoptar, sempre que possível, sentenças autoaplicativas"; cf. A decisão de inconstitucionalidade, p. 499.

${ }^{218}$ A esse respeito, assinala Roger Stiefelmann Leal: "a positivação de resoluções de caráter normativo, seja sob a forma de sentenças aditivas ou substitutivas, seja mediante o uso da interpretação conforme à Constituição, modifica radicalmente o cenário político-institucional para conceber, no seio do regime democrático, um legislador paralelo". Cf. O efeito vinculante na jurisdição constitucional, p. 100.

${ }^{219}$ Roberto Pinardi tem a seguinte visão: "con i 'moniti' contenuti in pronunce di accoglimento la Corte si prefigge, com'è ovvio, di stimolare un rapido intervento degli organi legislativi, giocando anche sulla circostanza che tale intervento è reso oggetivamente più urgente quale conseguenza della contemporanea eliminazione della disciplina sottoposta al suo sindicato". Cf. L'horror vacui nel giudizio sulle leggi, $p$. 114.

${ }^{220}$ Sobre tal aspecto, afirma Markus González Beilfuss: "lo que pretende precisamente el modelo bilateral o multilateral de reparación de la inconstitucionalidad es armonizar, en la medida de lo posible, los diversos bienes jurídicos que pueden concurrir en el restablecimiento de la igualdad y proteger, de este modo, la supremacía constitucional entendida en sentido amplio". Cf. Tribunal constitucional y 
Por fim, vale registrar que, inobstante as qualidades do modelo bilateral, este não é o método adequado para toda e qualquer violação à igualdade constitucional. Como visto, existem circunstâncias em que o modelo judicial unilateral se mostra plenamente admissível. O que se pretende destacar é que, nas hipóteses em que o controle judicial se mostrar prejudicial à segurança jurídica ou à separação de poderes, surge o modelo bilateral como uma alternativa viável.

Analisadas as características e a admissibilidade do modelo reparatório bilateral, cabe avaliar os requisitos que, quando satisfeitos, permitem a escolha deste método.

\subsubsection{Requisitos}

Tal como ocorre com o modelo unilateral, cuja instauração depende do preenchimento de determinados requisitos, já elencados, o modelo bilateral também não configura uma via corretiva da qual é possível dispor quando bem entender o órgão judicial. O instituto do apelo ao legislador, com todos os seus consectários procedimentais, somente pode ser utilizado se o caso concreto, bem como a legislação infraconstitucional impugnada e a norma parâmetro constitucional, preencherem determinadas condições, as quais são delineadas a seguir.

O primeiro requisito a ser tratado corresponde, simetricamente, ao oposto do que foi alinhado como primeiro requisito para o modelo unilateral. Enquanto este modelo somente se justifica quando houver uma relação de igualdade bem definida ao nível constitucional, o modelo bilateral exsurge como método adequado quando a norma parâmetro de igualdade não indicar com precisão qual a relação necessária entre determinados sujeitos e regimes jurídicos. Vale dizer, o método bilateral mostra-se apropriado para as situações em que a igualdade incidir na condição de cláusula geral da Constituição, sem explicitar os sujeitos, critérios e finalidades e sem expor a necessária relação entre estes elementos.

reparación de la discriminación normativa, p. 179. No mesmo sentido, assevera Rui Medeiros: “a solução proposta constitui um travão à tendência para a 'desresponsabilização do legislador', harmonizando-se, coerentemente, com a ideia de que, num Estado Democrático, cabe aos representantes do povo aprovar legislação conforme a Lei Fundamental". Cf. A decisão de inconstitucionalidade, p. 523. 
Uma vez incidindo como regra geral sem maiores detalhamentos, o direito de igualdade nada mais representa senão uma exigência genérica de correlação lógica entre os elementos estruturais da igualdade, de igual consideração e respeito de todos e de equilíbrio na atribuição de bens, direitos e obrigações, o qual deverá seguir ou a lógica da igualdade entre iguais ou a lógica da igualdade proporcional - que requer um tratamento desigual para sujeitos desiguais. Ou seja, incidindo como regra geral, o direito de igualdade dificilmente ensejará a imposição de uma relação internormativa específica. Ao fim e ao cabo, consistirá numa diretriz constitucional concretizável com diversos formatos e, portanto, requerente de uma interposição legislativa. Isso não quer dizer, entretanto, que a igualdade será desprovida de eficácia normativa, mas sim que admitirá variáveis formatações. A diferença é tênue, mas relevante.

A imagem hipotética a partir da qual se constrói o modelo bilateral já foi oportunamente exposta. Trata-se da situação em que, constatada uma violação à igualdade constitucional e declarada a sua nulidade, subsiste uma grande variedade de soluções compatíveis com a Constituição. É o caso em que o legislador oferece tratamento desigual para sujeitos que deveriam ser tratados de modo equiparado. Constatada a inconstitucionalidade, restará uma série de possibilidades normativas para se equiparar os regimes jurídicos, haja vista que a equivalência poderá se dar em diversos patamares, sendo que estes, em regra, não estão definidos pela Constituição. Nestas circunstâncias, ao legislador deverá ser aberta a possibilidade de restaurar o estado de igualdade, equiparando os regimes jurídicos no patamar que considerar adequado $^{221}$.

Noutro giro, a insuficiência da sanção de nulidade também constitui requisito para a instauração do método reparatório bilateral. Contrariamente ao que ocorre na sistemática unilateral, que se justifica nas hipóteses de inconstitucionalidade expressa e isolada, onde a eliminação pura e simples de enunciados normativos é apta a restaurar o estado de igualdade, o método bilateral mostra-se pertinente em face de violações implícitas no ordenamento. É o caso dos excessos e das insuficiências que, por não se encontrarem isoladas, impedem uma decisão de inconstitucionalidade

\footnotetext{
${ }^{221}$ Esta circunstância é constatada por Carlos Blanco de Morais: "A razão de ser da relutância do Tribunal Constitucional, neste tipo de sentenças, em proceder directamente ao preenchimento de uma lacuna técnica ou axiológica através da indicação de uma norma, prende-se ao facto desse vazio poder ser, em tese, passível de integração por mais do que uma solução normativa conforme à Constituição". Cf. Justiça Constitucional, tomo II, p. 399.
} 
simples que elimine a concessão ou a restrição responsável pela inconstitucionalidade. Nesta circunstância, somente o legislador poderá reformar o ordenamento de modo a restabelecer a igualdade.

Em outras palavras, o método bilateral é eficaz e legítimo na correção de afrontas à igualdade decorrentes de comparações sistemáticas realizadas pelo intérprete, que verifica na equiparação ou na diferenciação de dois regimes jurídicos uma violação ao direito de igualdade. Assim, constando-se que a equiparação ou a diferenciação não resulta de um preceito isolado, responsável pela inclusão ou exclusão geradora da lesão à igualdade, mas sim de uma interpretação judicial que, ao comparar dois regimes jurídicos positivados sem uma necessária correlação entre ambos, identificou um vício de inconstitucionalidade, o órgão judicial não poderá transfigurar o alcance normativo de algum dos regimes para, com isso, adequá-lo ao direito de igualdade.

Mais uma vez, exemplifica-se a situação supra com um exemplo de dimensões numéricas. Suponha-se que o legislador de determinado ente federativo tenha positivado um tributo com alíquotas diferentes para A e B. Imagine-se, ainda, que tais alíquotas fossem tradicionalmente diferenciadas, não configurando a desigualdade uma novidade no ordenamento. Nesta circunstância, caso o intérprete venha a identificar na desigualdade uma violação à igualdade constitucional, não poderá remodelar a alíquota de $\mathrm{A}$ ou de $\mathrm{B}$, de modo a equipará-lo ao outro. Afinal, tal alteração culminaria na invasão de um juízo discricionário do legislador. Diferente seria o caso em que dois sujeitos, A e B, fossem tradicionalmente tratados de forma equiparada com relação à alíquota de um tributo, mas que, por razões incompatíveis com a igualdade, algum deles fosse alvo de um incremento na alíquota, ou de um benefício consistente na redução desta alíquota. Enquanto no primeiro caso não haveria um preceito isolado cuja eliminação seria hábil a estabelecer a igualdade, na segunda hipótese uma decisão simples de inconstitucionalidade da inovação legislativa seria perfeitamente apta a restabelecer a igualdade anteriormente vigente.

Diante da primeira hipótese acima ilustrada, ao órgão judicial não competirá manipular o sentido normativo de modo a equiparar os regimes jurídicos. A saída será remeter a questão ao poder legislativo, abrindo-lhe a possibilidade de reformar as alíquotas e deixá-las equivalentes entre si. Nesta ocasião, o órgão judicial deverá comunicar seu entendimento sobre o sentido de igualdade requerido pela Constituição 
para aquela relação internormativa. No caso, deverá comunicar que a igualdade entre ambos exige uma equiparação de regimes.

Tal tipo decisório, que remete à reforma do ordenamento ao legislador, com a indicação da diretriz constitucional a ser respeitada, corresponde à chamada sentença aditiva de princípio, típica da jurisdição constitucional italiana ${ }^{222}$. Trata-se, aqui, de um modelo decisório que evita a reparação unilateral, resignando-se o órgão judicial a definir o princípio que rege a matéria e que deve ser concretizado pelo legislador. Do mesmo modo, o instituto se aproxima da figura alemã da "inconstitucionalidade sem nulidade" (decisão de incompatibilidade), que também exorta o legislador a reparar a inconstitucionalidade ${ }^{223}$.

Além dos requisitos descritos (inexistência de solução constitucional definitiva e insuficiência da sanção de nulidade para restauração da igualdade), outros elementos também podem vir a indicar a correção da inconstitucionalidade através do modelo bilateral. Um deles, já citado, seria o perigo do vazio jurídico (horror vacui). Embora sua existência potencial não configure, propriamente, um requisito do modelo bilateral, ele representa um aspecto relevante para a justificação do modelo bilateral como um método que evita soluções drásticas. Em razão dele, a comunicação do legislador configura medida de proteção da segurança jurídica.

Por fim, é possível citar o elemento orçamentário como fator relevante para a justificação da competência reparatória legislativa. Como se sabe, eventuais extensões de direitos ou restrições de obrigações, em nome da igualdade, podem vir a acarretar em substancial incremento das despesas estatais, sem haver contrapartida nas receitas. Nesse sentido, são particulares as questões relativas às prestações positivas do Estado

\footnotetext{
${ }^{222}$ Sobre as sentenças aditivas de princípio, ensina Roger Stiefelmann Leal: "Encontram-se, ainda, na experiência constitucional italiana, decisões designadas por sentenças aditivas de princípio. Em tais casos, declara-se a inconstitucionalidade de um ato normativo até que o legislador ultime novo diploma legal que estabeleça medida exigida constitucionalmente, segundo os princípios enunciados pela Corte. De um lado, exorta-se o legislador à superação da omissão parcial. De outro, reconhece-se a inconstitucionalidade do ato normativo questionado até a superveniência da lei requerida. A Corte Constitucional italiana, nessa hipótese, conduz-se com maior parcimônia, não complementando, de imediato, o texto legal defeituoso. Restringe-se a enunciar princípios gerais a serem observados pelo legislador na elaboração do diploma faltante". Cf. O efeito vinculante na jurisdição constitucional, pp. 89-90.

${ }^{223}$ A comparação é feita por Carlos Blanco de Morais: “Julga-se que a ser assim, tratando-se de sentenças que proferem uma decisão positiva de inconstitucionalidade, a figura algo mais próxima na ordem constitucional alemã será a das decisões de incompatibilidade constitucional sem declaração de nulidade, onde se procede, simultaneamente, a um apelo para a integração de um silencia gerador de uma omissão com carácter relativo". Cf. Justiça constitucional, tomo II, p. 398.
} 
(direitos sociais) e à tributação, neste caso porque reparações unilaterais podem acarretar em renúncias de receitas e direitos de restituição ${ }^{224}$. Nestas circunstâncias, o desequilíbrio orçamentário constitui elemento a ser considerado pelo órgão judicial, refletindo mais um fator que justifica o método bilateral. Afinal, o poder legislativo terá maiores condições de avaliar o impacto orçamentário da reforma legislativa a ser feita, além de ter a sua disposição melhores instrumentos de compatibilização do orçamento estatal com o restabelecimento da igualdade constitucional ${ }^{225}$.

\footnotetext{
${ }^{224}$ A questão é destacada por Carlos Blanco de Morais, quando trata dos "custos financeiros das decisões aditivas de prestação e violação do princípio do equilíbrio orçamental". Sobre o tema, pondera o autor: "Finalmente, o alargamento automática de certos benefícios materiais ou financeiros por parte de sentenças aditivas de prestação, ou outras com efeitos idênticos, poderia colidir com outras disposições constitucionais, como as das leis-travão que asseguram a estabilidade orçamental. Se, por exemplo, uma decisão do Tribunal Constitucional alargar certos subsídios pecuniariamente relevantes a estrangeiros residentes, que não se encontrem incluídos numa previsão legal, a qual os conferia apenas a nacionais, dela resultaria um aumento anómalo da despesa, podendo estar em causa uma ofensa às regras constitucionais que vedam iniciativas ou decisões não governamentais, susceptíveis de desequilibrarem negativamente o Orçamento do Estado". Cf. Justiça constitucional, tomo II, pp. 416-417.

${ }^{225}$ No mesmo sentido, afirma Rui Medeiros: "Salta portanto à vista que, na medida em que a concretização das normas constitucionais implique escolhas políticas (frequentemente muito delicadas), num quadro limitado de meios financeiros e materiais, a decisão deve estar reservada ao legislador". Cf. A decisão de inconstitucionalidade, p. 505.
} 


\section{IV) Aspectos Processuais}

4.1. Considerações gerais; 4.2. Reparação unilateral em controle concreto; 4.2.1. Características; 4.2.2. Dilemas; 4.2.3. Crítica; 4.3. Reparação unilateral em controle abstrato; 4.3.1. Características; 4.3.2. Dilemas; 4.3.3. Crítica; 4.4. Reparação bilateral; 4.4.1 Características; 4.4.2. Dilemas; 4.4.3. Crítica.

\subsection{CONSIDERAÇões GERAIS}

Como última etapa do estudo sobre a jurisdição constitucional da igualdade, cabe analisar as questões processuais que envolvem o tema. A razão de um capítulo final com esta temática vincula-se à própria lógica dedutiva de aplicação do direito de igualdade, que nasceu com a definição abstrata do seu significado, passou pelos fundamentos da sua tutela judicial, caminhou para o estudo de sua competência reparatória e agora culmina na investigação dos principais pontos relativos aos processos judiciais em espécie.

A relevância de um estudo sobre os aspectos processuais é inegável. A razão disso é que todos os delineamentos feitos até o momento sofrem limitações processuais para a sua aplicação prática. Afinal, a depender do instrumento processual utilizado, serão distintos: a extensão do objeto da demanda, a eficácia subjetiva das decisões, a vinculação da decisão em face de outros órgãos e poderes, entre outros. Portanto, sem um exame de aspectos pragmáticos e concretos, até mesmo a utilidade de todo o desenvolvimento prévio pode ser questionada.

Para enfrentar as questões de caráter processual, o capítulo quarto será dividido em três tópicos, dois deles referentes ao modelo unilateral e o último relativo ao modelo bilateral. Primeiramente, serão analisadas as características procedimentais do modelo reparatório concreto. Em seguida, serão descritos alguns dilemas enfrentados por este modelo, culminando no exame crítico da aplicação deste método de controle. Do mesmo modo, os itens relativos à reparação unilateral em processo principal e à 
reparação bilateral também serão divididos em subitens sobre as características e os dilemas, culminando em análises críticas das questões levantadas.

\subsection{ReParação Unilateral EM CONTROLE CONCRETo}

\subsubsection{Características}

Sabe-se que o controle de constitucionalidade, no Brasil, pode ser efetuado por todo e qualquer órgão judicial, razão pela qual se considera que a competência para a apreciação de questões constitucionais é difusa ${ }^{226}$. Em nosso sistema, que tem suas origens históricas fundadas no modelo norte-americano de judicial review, considera-se que o controle de constitucionalidade é decorrência lógica da supremacia e da rigidez da Constituição, dogmas que exigem de todas as normas infraconstitucionais uma compatibilidade material com esta, sob pena de invalidade ${ }^{227}$. Assim, uma vez que compete aos órgãos judiciais aplicar o direito válido e, portanto, em conformidade com a Constituição, infere-se que cabe a ele afastar disposições normativas em discordância com os preceitos constitucionais, ainda que isso represente um controle sobre os atos promulgados pelo poder legislativo ${ }^{228}$.

\footnotetext{
${ }^{226}$ Vale a citação de Alfredo Buzaid: "O poder de declarar a inconstitucionalidade compete, no sistema do direito público brasileiro, privativamente ao Judiciário. Exerce-o não apenas o tribunal de segundo grau, ou o Supremo Tribunal Federal; qualquer juiz, quando deve resolver os litígios submetidos ao seu conhecimento, pode decretá-la, porque é da índole de sua função, ao dizer o direito em cada caso concreto, deixar de aplicar a lei, que contraria direta ou indiretamente a Constituição". Cf. Da ação direta de declaração de inconstitucionalidade no direito brasileiro, p. 59. No mesmo sentido, ensina Luis Roberto Barroso: "O controle incidental de constitucionalidade é um controle exercido de modo difuso, cabendo a todos os órgãos judiciais indistintamente, tanto de primeiro como de segundo grau, bem como aos tribunais superiores. Por tratar-se de atribuição inerente ao desempenho normal da função jurisdicional, qualquer juiz ou tribunal, no ato de realização do Direito nas situações concretas que lhes são submetidas, tem o poder-dever de deixar de aplicar o ato legislativo conflitante com a Constituição". Cf. O controle de constitucionalidade no direito brasileiro, p. 82.

${ }^{227}$ Sobre o entrelaçamento entre rigidez e supremacia constitucionais na condição de fundamentos para a nulidade dos atos contrários, afirma Elival da Silva Ramos: "o que importa, entretanto, é deixar patenteado que a rigidez e a supremacia (formal) das normas constitucionais estão umbilicalmente ligadas, devendo-se entender a supremacia hierárquica, simultaneamente, como regra estrutural (do ordenamento) e como um princípio constitucional, inferido, enquanto tal, das normas agasalhadoras da rigidez e do controle de constitucionalidade". Cf. A inconstitucionalidade das leis: vício e sanção, São Paulo: Saraiva, 1994, p. 61.

${ }^{228}$ Alexander Hamilton manifesta-se claramente sobre o assunto: "A integral independência das cortes de justiça é particularmente essencial em uma Constituição limitada. Ao qualificar uma Constituição como limitada, quero dizer que ela contém certas restrições específicas à autoridade legislativa, tais como, por exemplo, não aprovar projetos de confiscos, leis ex post facto e outras similares. Limitações dessa natureza somente poderão ser preservadas na prática através das cortes de justiça, que têm o dever de declarar nulos todos os atos contrários ao manifesto espírito da Constituição. Sem isso, todas as restrições contra os privilégios ou concessões particulares serão inúteis". Cf. O federalista, p. 479.
} 
$\mathrm{Na}$ fiscalização concreta da constitucionalidade dos atos normativos, a inconstitucionalidade é arguida incidenter tantum, apenas na medida em que sustenta o pedido formulado ${ }^{229}$. Assim, a declaração de inconstitucionalidade não constitui, propriamente, o objeto específico da demanda, mas sim um poder-dever atribuído aos órgãos judiciais de não aplicar determinada norma que, ao regular a solução da lide, for incompatível com a Constituição. Nestas circunstâncias, o órgão judicial deverá afastar a norma inconstitucional e decidir o litígio segundo os parâmetros da norma anterior, ou pela integração da lacuna surgida ${ }^{230}$.

Vale consignar que, na reparação promovida em processo incidental, a correção tem validade apenas entre as partes do processo (inter partes) ${ }^{231}$, sendo esta uma característica essencial para o presente estudo. Isto é, a eficácia da declaração de inconstitucionalidade, no controle incidental, é limitada ao processo específico, restando a norma plenamente aplicável a outros casos singulares, ainda que semelhantes ${ }^{232}$. Tal sistemática é consequência da lógica subjetiva e concreta do controle incidental, que

\footnotetext{
${ }^{229}$ Segundo Clèmerson Merlin Clève, "nos termos da tradição americana, pode o Judiciário, no curso de qualquer demanda, apreciar questão de inconstitucionalidade, arguida incidenter tantum, como questão prejudicial de mérito". Cf. A fiscalização abstrata da constitucionalidade no direito brasileiro, p. 91.

${ }^{230}$ Vale citar as palavras de Jorge Miranda: "A fiscalização concreta pressupõe três poderes: o de determinar a norma aplicável ao caso, o de apreciar a sua conformidade com a Constituição e, como consequência, o de não a aplicar quando desconforme. Mas, como os juízes não podem deixar de julgar, este poder acha-se, de ordinário, coenvolvido com um poder positivo: o de aplicar a norma anterior quando se esteja diante de inconstitucionalidade originária; e, na falta de norma aplicável - seja por não haver norma anterior repristinável, seja por a inconstitucionalidade ser superveniente - o poder de preencher a lacuna através dos critérios gerais de integração". Cf. Manual de direito constitucional, tomo VI, p. 69.

${ }^{231}$ Cita-se, neste ponto, a lição de Carlos Blanco de Morais: "Finalmente, na fiscalização concreta, os efeitos de um julgamento no sentido da inconstitucionalidade de um acto produzem somente consequências singulares, já que a desaplicação do referido acto circunscreve-se ao caso 'sub iuditio', vinculando apenas o juiz do tribunal ' $a$ quo' e os intervenientes processuais. Existe, deste modo, uma eficácia 'inter-partes', podendo o acto continuar a aplicar-se a outras situações singulares. Cf. Justiça constitucional, tomo I: garantia da Constituição e controlo da constitucionalidade. $2^{\mathrm{a}}$ ed. Coimbra: Coimbra Editora, 2006.p. 186.

${ }^{232}$ Nas palavras de Zeno Veloso: "No controle difuso, a alegação da inconstitucionalidade não é a demanda principal, constituindo questão prejudicial. O juízo de inconstitucionalidade é suscitado incidentalmente, por ser relevante e necessário para se saber se a lei vai ser aplicada, ou não, ao caso concreto. Se houver a declaração de inconstitucionalidade, arguida como questão prejudicial, a consequência é a não-aplicação da norma impugnada na relação jurídica em exame. Não há a invalidação da lei, de modo geral, perante todos. A decisão afasta, apenas, a sua incidência no caso, para o caso e entre as partes. A eficácia da sentença é restrita, particular, refere-se, comente, à lide, subtrai a utilização da lei questionada ao caso sob julgamento, não opera erga omnes. A lei, teoricamente, continua em vigor, não perde a sua força obrigatória com relação a terceiros, sendo aplicada a outros casos". Cf. Controle jurisdicional de constitucionalidade, p. 41.
} 
não tem por função julgar a lei, mas sim afastá-la quando eivada de inconstitucionalidade ${ }^{233}$.

No que tange ao direito de igualdade, a lógica não é diferente: normas infraconstitucionais inconciliáveis com a igualdade determinada em nível constitucional devem ser repudiadas pelo aplicador do direito. Assim, regimes normativos violadores da igualdade, seja por insuficiência ou por excesso em comparação com regime merecedor de tratamento equivalente, seja por equiparação a regime merecedor de tratamento proporcionalmente desigual, devem ser reputados inconstitucionais. Em outras palavras, regimes normativos que estejam além ou aquém do que determina a igualdade constitucional e, com isso, repercutam de modo negativo na esfera jurídica de um sujeito de direitos, devem ser rechaçados pela autoridade judicial competente ${ }^{234}$.

Quando se trata de controle incidental de constitucionalidade com base na igualdade, em regra as demandas têm a mesma racionalidade e objetivo: obter uma situação mais vantajosa para o autor da ação. Esta vantagem, por sua vez, pode corresponder a duas circunstâncias essenciais: o aumento de um benefício (direito), ou a redução de um sacrifício (obrigação). De todo modo, a vantagem almejada tem como parâmetro um terceiro regime jurídico infraconstitucional (tertium comparationis), que é utilizado pelo autor da demanda para justificar seu pedido.

É certo que podem surgir circunstâncias em que o objetivo do demandante é restringir vantagens consideradas inconstitucionais por ofertarem tratamentos privilegiados a sujeitos que deveriam ser tratados como iguais (igualdade paritária), ou por atribuírem porções excessivas de benefício a alguns sujeitos. Pleitos com essa racionalidade podem ser identificados em ações que, nalguma medida, estejam voltadas antes para o interesse público que para interesses particulares. Neste quesito, não seria demais lembrar da possibilidade de ações populares ou ações civis públicas que objetivem eliminar benefícios dissonantes com a igualdade.

\footnotetext{
233 Alfredo Buzaid é enfático: "Não se deve perder de vista nunca que a função do Judiciário não é julgar a lei, declarando-a nula; mas sim subtrair-lhe a aplicação, quando ela está viciada de inconstitucionalidade". Cf. Da ação direta de declaração de inconstitucionalidade no direito brasileiro, p. 87

${ }^{234}$ Eis uma decorrência do viés subjetivista da garantia de constitucionalidade do ordenamento jurídico, tal como visualizado por Jorge Miranda, ao afirmar que "é a norma de garantia, e não a Constituição em globo, que cria para os cidadãos um direito em relação à constitucionalidade; o de levarem órgãos jurisdicionais a decidir sobre o valor jurídico de certas normas e certos actos”. Cf. Contributo, p. 275.
} 
De qualquer modo, usualmente se requer uma posição jurídica mais vantajosa, com base na comparação com um regime jurídico atribuído a um sujeito que, na visão do autor da demanda, é digno do mesmo tratamento, haja vista a aplicação da igualdade paritária ou da igualdade proporcional no seu viés de igual entre iguais. Embora mais raras, também existem demandas que requerem a aplicação de regime mais vantajoso através da diferenciação do autor em face de um sujeito que o legislador considerou merecedor de um tratamento igual. Neste último caso, os pleitos correspondem a um privilégio em face do sujeito equiparado, ou a uma desoneração não recebida por este, ambas com o fundamento de que o autor merece tratamento jurídico desigual, na medida de sua desigualdade (igualdade proporcional entre desiguais).

Exemplos não faltam para ilustrar o raciocínio acima, especialmente as que pleiteiam equiparações.

Controvérsias tipicamente enfrentadas pela jurisdição constitucional da igualdade são as de ações judiciais de categorias de servidores públicos que pretendem obter a mesma remuneração, ou o mesmo reajuste salarial, ou o mesmo benefício previdenciário, enfim, que uma terceira categoria que os autores reputam iguais em sentido estrito (igualdade paritária ou igualdade proporcional entre iguais). Em tais casos, o objetivo do demandante é a extensão do regime jurídico mais vantajoso à sua esfera de direitos, haja vista a existência de uma diferenciação que, na sua visão, afronta o direito constitucional de igualdade.

Casos concretos da jurisprudência do Supremo Tribunal Federal com esse viés são facilmente encontrados. Cite-se o recente ARE 672413 AgR / RS ${ }^{235}$, no qual se sustentou que a revisão geral anual não pode ser atribuída de forma desigual aos postos militares, de acordo com o escalão, sob pena de violação do princípio da isonomia, razão pela qual se pleiteava a atribuição do percentual do maior índice concedido pela lei 11.784/2008 a todos os militares, independentemente do escalão. No mesmo sentido, pode ser citado o ARE $661869 \mathrm{AgR} / \mathrm{RJ}^{236}$, em que o Sindicato dos Servidores do Poder Judiciário do Estado do Rio Janeiro pleiteou a incorporação a todos os filiados da

\footnotetext{
${ }^{235}$ ARE 672413 AgR / RS; Relator(a): Min. ROSA WEBER; Julgamento: 07/05/2013; Órgão Julgador: Primeira Turma.

${ }^{236}$ ARE 661869 AgR / RJ; Relator(a): Min. TEORI ZAVASCKI; Julgamento: 16/04/2013; Órgão Julgador: Segunda Turma.
} 
entidade, ou seja, ativo, inativo e pensionistas, e de uma única vez, o reajuste no percentual de $24 \%$ originalmente ofertado apenas aos servidores ativos.

Noutro giro, também são frequentes ações judiciais que, em nome da igualdade, pleiteiam a redução de obrigações até o patamar em que se encontrem terceiros vistos como merecedores de tratamento equivalente. Típicas nesse sentido são as demandas que requerem desonerações tributárias nos mesmos moldes daquelas ofertadas a sujeitos que, na concepção dos autores, devem ser tratados de forma equivalente. Em geral, os interessados afirmam haver uma exclusão, explícita ou implícita, que os discriminou em face dos sujeitos abrangidos pela desoneração e que tal diferenciação não guarda coerência com o direito constitucional de igualdade.

Exemplo concreto, e recente, de decisão do Supremo Tribunal Federal que enfrentou pedido nesses moldes pode ser constatado no RE $528160 \mathrm{AgR} / \mathrm{SP}^{237}$. Neste caso, um banco pleiteou a redução da alíquota de Contribuição Social sobre o Lucro Líquido, sob o fundamento de que a incidência de alíquota diferenciada e mais gravosa para instituições financeiras violaria o direito de igualdade. Outro caso que se enquadra na hipótese descrita pode ser encontrado no RE 405579 / $\mathrm{PR}^{238}$, em que uma importadora de pneus requereu a extensão de benefício fiscal, originalmente concedido a montadoras, para empresas de reposição de pneumáticos, sustendo que a sua exclusão era decorrente de critério excessivamente restritivo e, por isso, violador da igualdade.

O que todos esses casos têm em comum, para além da questão da igualdade, é a existência de interesses jurídicos concretos, específicos e individuais. Em suma, no controle incidental a jurisdição é colocada a serviço do sistema de garantia subjetiva da igualdade, motivo pelo qual ela só se instaura quando a inconstitucionalidade repercute na esfera dos direitos e deveres dos cidadãos. A constituição, enfim, é garantida à medida que surgem interesses subjetivos fundados nos seus dizeres ${ }^{239}$.

Tendo em vista as propriedades normativas do direito de igualdade, já amplamente estudados, não é demais afirmar que este direito representa um parâmetro

\footnotetext{
${ }^{237}$ RE 528160 AgR / SP ; Relator(a): Min. CÁRMEN LÚCIA; Julgamento: 21/05/2013; Órgão Julgador: Segunda Turma.

${ }^{238}$ RE 405579 / PR; Relator(a): Min. JOAQUIM BARBOSA; Julgamento: 01/12/2010; Órgão Julgador: Tribunal Pleno.

${ }^{239}$ No mesmo sentido, afirma Jorge Miranda: "só se põe em andamento a fiscalização, quando a ofensa ou a ameaça de ofensa à Constituição se repercute na esfera dos direitos e deveres dos cidadãos e das sociedades menores integradas no Estado". Cf. Contributo para uma teoria da inconstitucionalidade, p. 273.
} 
onipresente, apto a fundamentar pleitos judiciais dos mais diversos espectros. Por outro lado, sua delimitação como instrumento singular, de alcance limitado à lide concretamente colocada perante o poder judiciário, traz dilemas de suma importância, haja vista a limitação do seu potencial reparatório. Em síntese, a garantia subjetiva da igualdade, embora seja dotada de uma força proporcional à soma dos interesses dos cidadãos, provoca uma reconfiguração peculiar do sistema normativo, pautado que é na generalidade e abstração dos atos normativos. Este e outros dilemas enfrentados pelo controle incidental são abordados a seguir.

\subsubsection{Dilemas}

Ao longo deste trabalho, verificou-se que o direito de igualdade possui uma eficácia abrangente, atuando como metanorma reguladora das atividades de criação e aplicação do Direito. Por tal razão, representa parâmetro hábil a fundamentar diversos pleitos judiciais, em múltiplas matérias. Ademais, demonstrou-se que o direito de igualdade incide sobre relações internormativas, configurando norma de natureza estruturante que, ao regular as demais normas, exige coerência lógica, respeito à igualdade originária de todos (que nascem iguais em direitos) e equilíbrio na definição de direitos e obrigações. Por conseguinte, estabeleceu-se que os vícios de inconstitucionalidade devem ser identificados a partir de relações tripolares que envolvem uma norma constitucional de igualdade e duas normas infraconstitucionais colocadas em comparação.

Das condições alinhadas acima resulta que, num processo instaurado por suposta violação à igualdade constitucional, o ideal seria o exame de todo o complexo normativo envolvido na questão, ou seja, tanto da norma impugnada, quanto da norma que serve de parâmetro para comparação (tertium comparationis). Por este prisma, não só a análise seria mais abrangente, como também sucederiam opções mais adequadas de solução judicial. Ocorre que tais soluções não são perfeitamente adaptáveis ao processo incidental de controle, que é regido por normas processuais delimitadoras do seu objeto e efeitos, regras estas que provocam os seguintes dilemas.

O primeiro dilema da reparação judicial realizada incidentalmente diz respeito ao objeto da demanda, que, formulado pelo autor, pauta a atividade 
jurisdicional $^{240}$. Com efeito, no controle incidental a alegação de inconstitucionalidade consiste apenas numa prejudicial do mérito pleiteado pelo autor da demanda, e não o objeto principal do processo. Nesse sentido, a inconstitucionalidade incidental não passa de um fundamento para o eventual provimento do pedido que, em realidade, busca um bem da vida qualquer ${ }^{241}$. Por esta razão, é preciso ter em mente que o órgão judicial não poderá, em controle incidental, reformular a relação internormativa eivada de inconstitucionalidade da forma como considerar mais adequado com relação ao ordenamento jurídico como um todo, mas sim deverá reparar a inconstitucionalidade à medida que esta correção seja apta a embasar a concessão do bem almejado.

Para exemplificar a situação descrita, basta imaginar a seguinte questão: um sujeito A propõe uma ação judicial alegando violação do seu direito de igualdade porque determinado regime jurídico a que está submetido é menos vantajoso (prevê menos direitos, ou mais obrigações) que o regime jurídico a que está adstrito o sujeito B, o qual, na visão do demandante, deve ser tratado de modo equivalente (igualdadeparidade). Diante dessa circunstância, poderia o órgão judicial, uma vez convencido de que o direito constitucional de igualdade realmente exige que haja uma equiparação entre os sujeitos A e B, reconhecer a inconstitucionalidade não na insuficiência do regime jurídico de A (autor da ação), mas sim no excesso da vantagem usufruída pelo sujeito B, que sequer é parte no processo? Competiria ao poder judiciário modificar o regime deste ao invés daquele, reduzindo o alcance do regime $\mathrm{B}$ ao invés de aumentar o alcance do regime $\mathrm{A}$ ?

As respostas são negativas. Ao extravasar o âmbito do pedido formulado pelo autor, invadindo esfera alheia aos limites da demanda, o órgão judicial viola dogma elementar da função judicial, qual seja, o princípio da inércia judicial ${ }^{242}$. Afinal, é

\footnotetext{
${ }^{240}$ Vale citar a lição de Cândido Dinamarco: "Na vida do processo, tudo gira em torno desse seu objeto: a demanda com que o autor postula a tutela jurisdicional, a defesa com que o réu resiste, as provas com que se procura demonstrar a ocorrência de fatos capazes de gerar o direito afirmado etc. - tudo caminhando até ao ato final com que o juiz dispõe sobre a pretensão deduzida (no processo de conhecimento, sentença de mérito; na execução, ordem de entrega). Numa das pontas do processo está uma situação da vida, que o demandante lamenta e pede que seja alterada; na outra, o resultado final com que se elimina o conflito entre os litigantes e, se o demandante tiver razão, oferece-lhe uma nova situação da vida, mais favorável que a primeira". Cf. Instituições de direito processual civil, vol. II, p. 181.

${ }^{241}$ Mais uma vez, cita-se Cândido Dinamarco: "Objeto do processo é a pretensão a um bem da vida, quando apresentada ao Estado-juiz em busca de reconhecimento ou satisfação. É o material sobre o qual atuam as atividades jurisdicionais exercidas pelo juiz e todos os atos de defesa judicial dos direitos, realizados pelas partes". Cf. Cf. Instituições de direito processual civil, vol. II, p. 180.

${ }^{242}$ Em comentário sobre a jurisdição como "atividade provocada", ensina Athos Gusmão Carneiro: "A atividade jurisdicional é uma 'atividade provocada'. Não há jurisdição sem ação. (...) Os juízes não saem
} 
decorrência deste princípio a ideia de que a sentença judicial deve guardar correlação com o pedido ${ }^{243}$. Nesse sentido, ao órgão judicial caberá conhecer da inconstitucionalidade apenas na medida em que ela se relacionar com o pedido posto, não podendo o órgão judicial restabelecer o estado de igualdade senão pela forma como requerida em juízo, ou seja, estendendo o âmbito da vantagem do demandante até o patamar do terceiro a ser equiparado. Não convencido da tese, deve julgar o pedido improcedente. Outra forma de equiparação, que altere o regime jurídico de terceiro alheio ao processo, é vedada pelo sistema processual ${ }^{244}$.

É certo que a garantia da constitucionalidade não se vincula a interesses jurídicos específicos, tampouco configura direito disponível. De fato, a constitucionalidade dos atos normativos reflete uma questão de ordem pública ${ }^{245}$. Entretanto, não se deve perder de vista que, em sede de controle incidental das violações

em busca das lides para resolvê-las, mas aguardam que os interessados, frustradas eventuais tratativas amigáveis, busquem espontaneamente a intervenção estatal, propondo a demanda. Dois brocardos expressam a necessidade de um pedido, de uma demanda, para que o Estado preste tutela jurisdicional, e isso tanto em jurisdição contenciosa como na chamada jurisdição voluntária: nemo judex sine actore 'ninguém é juiz sem autor'. Ne procedat judex ex officio - 'não proceda o juiz de ofício'. O princípio da inércia inicial do Judiciário impõe-se no direito brasileiro com raríssimas exceções, e assim também nos demais países 'ocidentais"'. Cf. Jurisdição e competência, 14ª ed. São Paulo: Editora Saraiva, 2005, p. 9.

${ }^{243}$ Seguem as palavras de Cândido Dinamarco: "Assim, se o juiz se pronunciar sobre bem que não lhe foi pedido, ou apoiar-se em fundamentos não deduzidos pelo demandante, ou dispuser em relação a sujeitos que não sejam partes no processo, na parte excedente estará exercendo jurisdição ex officio. A sentença colidirá diretamente com o disposto nos arts. 128 e 460 do Código de Processo Civil, os quais constituem positivações da máxima ne eat judex ultra vel extra petita partium; colidirá também, indiretamente, com o nemo judex sine actore positivado nos arts. $2^{\circ}$ e 262 ; e, se dispuser em relação a sujeitos que não sejam partes no processo, estará o juiz estabelecendo um conflito com a garantia constitucional do contraditório. Se ele ficar aquém da demanda, restringindo indevidamente o pedido ou os fundamentos postos pelo demandante, ou omitindo-se quanto a algum deles ou em relação a alguma das partes, ele infringirá a garantia constitucional da ação e de acesso à justiça (Const., art. $5^{\circ}$, inc. XXXV). Tal é a fórmula sistemática e global da regra de correlação entre o provimento jurisdicional $e$ a demanda, a qual se apresenta com a dupla face de veto a excessos e de exigência de inteireza na oferta da tutela jurisdicional". Cf. Instituições de direito processual civil, vol. II, pp. 138-139.

${ }^{244}$ Elival da Silva Ramos afirma: "como sempre ocorre na via incidental, assume ela, em nosso sistema, feições concretas, pois não se discute por seu intermédio a inconstitucionalidade em tese de atos legislativos, examinando-se a mácula apenas na exata medida em que interfira na esfera subjetiva de pessoas públicas ou privadas, partícipes do processo na condição de autor, réu ou terceiro interveniente. Não se admite, por conseguinte, o ataque frontal à higidez do ato normativo por meio de instrumentos processuais de fiscalização incidental, tanto quanto não se admite o uso da via principal para a proteção de direitos ou interesses subjetivos ofendidos". Cf. Controle de constitucionalidade no Brasil: perspectivas de evolução, p. 255.

${ }^{245}$ Oportuno observar a análise de Jorge Miranda: “Além disso, nunca poderia entender-se disponível o direito à constitucionalidade. Na hipótese de existir como direito substantivo, não poderia conter a faculdade dos cidadãos de cederem o seu gozo ou renunciarem ao seu exercício e igualmente absurdo seria supor-se que, em qualquer circunstância, pudesse ser subtraído a algum cidadão, porque faltaria sempre um interesse subjectivo que fosse autónomo e particularizado, e não apenas geral. E ainda que se pudesse descobrir tal interesse, não seria de ordem privada: a conformidade das normas e dos actos de grau inferior com as normas de grau superior é de interesse e ordem pública". Cf. Contributo para uma teoria da inconstitucionalidade, p. 275. 
à igualdade constitucional, há uma inevitável comparação entre regimes normativos, sendo que o pedido formulado invariavelmente requer alguma posição de vantagem comparativa com um terceiro regime jurídico, seja sob o argumento de que o autor merece ser equiparado ao regime mais benéfico do terceiro, seja sob o argumento de que o autor deve ser receber tratamento privilegiado em relação ao terceiro, haja vista as desigualdades fáticas existentes entre ambos. Nesse contexto, restringir o alcance do regime jurídico utilizado como comparação equivaleria a um julgamento extra petita, desvinculado do bem da vida concretamente pleiteado em juízo e desvantajoso para todos os envolvidos.

Eis aqui o primeiro dos dilemas enfrentados pelo modelo reparatório unilateral realizado pela via do controle incidental de constitucionalidade. O seu objeto, restrito que é, impede uma análise global da relação internormativa questionada, impondo ao julgador poucas possibilidades de restauração da constitucionalidade. Ou esta é feita nos termos reivindicados pelo demandante - o que nem sempre representa a melhor forma de se corrigir o vício e, muitas vezes, sequer é permitida pelo ordenamento - ou se mantém a violação à igualdade por não haver medida judicial ao alcance do julgador.

O segundo dilema enfrentado pelo método reparatório unilateral em controle incidental refere-se à restrição dos seus efeitos apenas às partes do processo (eficácia inter partes). Não se pretende, aqui, questionar a constitucionalidade da eficácia inter partes das decisões jurisdicionais em face da igualdade, mas sim demonstrar algumas dificuldades enfrentadas pelo controle concreto para que seja alcançada a uniformização da jurisprudência, com a instauração de mecanismos de vinculação aos precedentes. Consoante será demonstrado, esses objetivos fundamentam-se, em grande medida, na igualdade $^{246}$.

\footnotetext{
${ }^{246}$ Sobre o assunto, afirma Andrés Ollero: "Ya vimos que el binômio igualdad de trato-igualdad de enjuiciamiento obligaba a plantear una operación comparativa, cuyo parangón forzoso sería el conjunto de resoluciones emitidas con anterioridad por el mismo órgano en supuestos idénticos. De ahí que - como consecuencia de dicho principio de igualdad en la aplicación de la ley - a un mismo órgano sólo le estaría 'permitido modificar el sentido de sus resoluciones, apartándo-se de las precedentes, empleando fundamentación suficiente y razonable'. Esta secuencia temporal lleva, sin embargo, inevitablemente a plantear el posible carácter vinculante de un nuevo punto de referencia normativo cuyo origen no estaría en la ley sino en una constatada regularidad judicial. La misma sentencia apunta ya, en un fundamento anterior, que a todo órgano aplicativo está vedado 'modificar arbitrariamente el sentido de sus resoluciones, salvo cuando su apartamiento de los precedentes posea una fundamentación suficiente y rasonada". Cf. Igualdad en la aplicación de la ley y precedente judicial, p. 75.
} 
Basicamente, o desafio a ser analisado é o da relação entre dois elementos: a individualidade ínsita à decisão judicial proferida em casos particulares e a generalidade inerente à lei. Nesta perspectiva, questiona-se o seguinte: em que medida uma sentença que repare uma afronta à igualdade apenas para alguns, justamente aqueles que se socorreram do judiciário e lograram êxito em suas demandas, gera incompatibilidade com a igualdade? Até que ponto a correção individual de uma lesão à igualdade representa uma defesa da igualdade e até que ponto importa em desequilíbrio do ordenamento jurídico?

Imagine-se que, diante de uma determinada violação à igualdade constitucional que repercuta na esfera jurídica de um grupo de mil indivíduos, somente metade deles ingresse no poder judiciário buscando resguardar seus direitos. Suponhase, ainda, que apenas metade desses sujeitos que propuseram ações judiciais (ou seja, duzentos e cinquenta indivíduos) obtenha decisões favoráveis. Nesse contexto, o grupo originário poderá ser dividido em três subgrupos: (i) aqueles que se resignaram à lesão; (ii) aqueles que, inobstante o acesso ao judiciário, não obtiveram a procedência dos seus pedidos e permanecem submetidos ao regime inconstitucional; e (iii) aqueles que obtiveram provimento de seus pleitos e, com isso, conseguiram afastar a incidência da norma inconstitucional. Em resumo, um grupo que sofria a repercussão da norma inconstitucional homogeneamente, agora se encontra também diante de diferenciações internas, sendo que estas desigualdades se dão por critérios comezinhos, quais sejam, a postura mais ou menos ativa em face de violações a seus direitos, a contratação de bons ou maus advogados, a distribuição das ações para juízes mais ou menos afeitos a suas demandas, entre outros.

Como se percebe, a questão aqui aventada relaciona-se intrinsecamente com os debates acerca da igualdade de tratamento perante o poder judiciário. De fato, a igualdade protegida em nível constitucional vincula não apenas o legislador, mas também o aplicador do direito, não faltando quem afirme que a "igualdade perante a lei" seja uma fórmula voltada, especialmente, para a regulação da atividade jurisdicional ${ }^{247}$. Como consequência do ideário de igualdade na aplicação do direito, é frequente

\footnotetext{
${ }^{247}$ É o que defende, dentre outros, Andrés Ollero: "La regla general de la igualdad ante la ley contenida en el artículo 14 de la Constitución se bifurca, por tanto. Contempla, en primer lugar, la igualdad en el trato dado por la ley, que pasa a conceptuarse como igualdad en la ley, constituyendo un límite puesto al ejercicio del poder legislativo. Junto a esta exigencia surge la igualdad en la aplicación de la ley, que limitará la tarea de los órganos encargados de su aplicación”. Cf. Igualdad en la aplicación de la ley y precedente judicial, p. 23.
} 
fundamentar-se, no direito de igualdade, o desenvolvimento de técnicas de uniformização da jurisprudência ${ }^{248}$, assim como a articulação de mecanismos de vinculação aos precedentes judiciais ${ }^{249}$ e a instituição de efeito vinculante nas decisões proferidas em sede de jurisdição constitucional $^{250}$.

Em suma, o controle realizado incidentalmente em casos particulares pode vir a provocar um desequilíbrio, ainda que momentâneo, no ordenamento jurídico, haja vista que a limitação dos seus efeitos subjetivos impede uma reconfiguração, genérica e abstrata, do conteúdo normativo responsável pela violação ao direito constitucional de igualdade. Tal situação torna-se ainda mais grave quando decisões em sentidos opostos transitam em julgado antes de ser obtida uma uniformização nos precedentes, ou antes de ser feita uma reforma da legislação inconstitucional.

Diante desses dilemas, tomam espaço algumas ponderações críticas e propositivas acerca da reparação judicial efetivada em controle incidental de constitucionalidade.

\subsubsection{Crítica}

Pelo exposto nas seções anteriores, nota-se que a reparação judicial via controle incidental de constitucionalidade não é inteiramente capaz de proteger o direito de igualdade. Tanto a citada restrição objetiva - necessidade de correlação entre pedido

\footnotetext{
${ }^{248}$ Nesse prisma, sustenta Rodolfo de Camargo Mancuso: “Já em países como o nosso, onde o primado é dado pela norma legal, a afirmada igualdade de todos perante a lei depende, para ser efetiva, de que existam técnicas e meios asseguradores de que aquela desejável igualdade continuará operante se e quando a norma venha submetida à exegese judiciária, ou seja, quando a norma sai do papel para se subsumir num caso concreto. Cf. Divergência jurisprudencial e súmula vinculante, $4^{\mathrm{a}}$ ed. São Paulo: Editora Revista dos Tribunais, 2010, p. 130.

${ }^{249}$ Nessa linha, avalia José Rogério Cruz e Tucci: “A jurisprudência consolidada garante a igualdade dos cidadãos perante a distribuição da justiça, porque situações assemelhadas são tratadas do mesmíssimo modo, e a democracia participativa exige a paridade de trato entre os membros da comunhão social. $\mathrm{O}$ tratamento desigual pelos tribunais é forte indício de injustiça em pelo menos um dos casos. Tão-somente justificadas razões peculiares autorizam o desvio dos precedentes judiciais". Cf. Precedente judicial como fonte do direito, São Paulo: Editora Revista dos Tribunais, 2004, p. 296.

${ }^{250}$ É o que afirma Roger Stiefelmann Leal, ao analisar os princípios que informam o instituto do efeito vinculante: "Trata-se, portanto, de instituto que opõe obstáculos à arbitrariedade e à discriminação na aplicação da Constituição. Aos casos e controvérsias que apresentarem identidade de circunstâncias não se admitirá resolução distinta, que discrepe da orientação firmada pelos órgãos de jurisdição constitucional. Promove-se, assim, o princípio da igualdade, na medida em que casos iguais merecerão, por parte dos demais poderes e órgãos do Estado, o mesmo tratamento constitucional: aquele dispensado no âmbito do controle jurisdicional de constitucionalidade". Cf. O efeito vinculante na jurisdição constitucional, pp. 115-116.
} 
e sentença - quanto a restrição subjetiva - eficácia inter partes da decisão - constituem obstáculos à efetivação do direito de igualdade no âmbito do poder judiciário, seja por impedirem uma correção adequada da inconstitucionalidade, seja por criarem diferenciações aleatórias entre os jurisdicionados.

O direito de igualdade é carregado de propriedades normativas peculiares que implicam numa sistemática própria de aplicação. Em razão do seu caráter metanormativo, regulador do processo de produção do direito, é de se concluir que sua jurisdição é melhor realizada quando existe a possibilidade de exame completo da relação internormativa tripolar questionada, bem assim quando a eficácia da solução jurisdicional é abrangente, erga omnes, não se limitando àqueles que se socorreram do judiciário e obtiveram êxito em seus pleitos. Afinal, a reparação de um desequilíbrio vinculado a atos legislativos não deveria gerar outra espécie de desequilíbrio, relacionada a atos jurisdicionais.

Dentre as soluções para esses dilemas, algumas passam por reformas substanciais do sistema brasileiro de jurisdição constitucional, ao passo que outras visam, simplesmente, atenuar os efeitos colaterais do exame incidental de constitucionalidade.

A primeira possibilidade de solução, mais drástica, diz respeito à transformação do controle de constitucionalidade sob o prisma orgânico-subjetivo, concentrando-se a capacidade de fiscalização da constitucionalidade das leis em órgão dotado de supremacia sobre os tribunais judiciários, ou seja, aderindo-se ao modelo europeu de competência exclusiva para realizar a jurisdição constitucional, onde os vícios de inconstitucionalidade recebem um tratamento eminentemente objetivo.

No debate jurídico acerca do sistema brasileiro de jurisdição constitucional, é frequente a defesa de um movimento no sentido descrito. Em geral, alude-se à necessidade de se concentrar a função de controle de constitucionalidade nas mãos do Supremo Tribunal Federal, sendo a igualdade na aplicação do direito um dos fatores preponderantes nesse propósito. A ideia é que a transformação traria maior 
uniformidade das decisões de controle, eliminando os efeitos deletérios da variação de interpretações da Constituição ${ }^{251}$.

Adotado o modelo, os vícios de inconstitucionalidade seriam sanados de forma abstrata e com eficácia erga omnes ${ }^{252}$. Destarte, ambos os dilemas aventados anteriormente seriam solucionados, equacionando-se os desajustes na aplicação do direito de igualdade. Em primeiro lugar, porque a questão dos limites processuais da arguição incidental seria relativizada, à medida que a remissão da análise para o tribunal constitucional acarretaria numa desvinculação relativa ao caso concreto, prevalecendo o aspecto objetivo do ordenamento sobre a condição subjetiva daquele que ajuizou a demanda $^{253}$. Em segundo lugar, porque os efeitos da decisão seriam gerais, ou seja, com validade para todos aqueles que se encontram na mesma situação, mas que não buscaram a proteção judicial, ou então não obtiveram êxito em suas ações.

Nada obstante os benefícios de eventual mudança do modelo brasileiro de controle de constitucionalidade, ao menos no que tange ao direito de igualdade, é necessário observar que esta não é a realidade atual. Na sua essência, o sistema brasileiro remanesce fundado no modelo norte-americano, sem uma convergência relevante com relação ao modelo europeu ${ }^{254}$. Ao invés de concentrar a jurisdição num

\footnotetext{
${ }^{251}$ É o que explicita Elival da Silva Ramos: "As tentativas de lidar com os efeitos deletérios de falta de uniformidade das decisões de controle não se mostraram, até aqui, satisfatórias, tanto que se renovam a todo momento, porquanto a causa dessa variação jurisprudencial está na forte presença em nosso sistema do controle difuso-incidental, com efeitos restritos às partes". Cf. Controle de constitucionalidade no Brasil: perspectivas de evolução, p. 482.

${ }^{252}$ Na lição de Elival da Silva Ramos, "as decisões de controle no sistema de matriz europeia produzem sempre efeitos gerais, já que tais efeitos são inerentes ao controle principal e, na via incidental, acabam decorrendo, em termos lógicos, da concentração da fiscalização". Cf. Controle de constitucionalidade no Brasil: perspectivas de evolução, p. 476.

${ }^{253}$ É o que leciona Louis Favoreu: "Do ponto de vista das funções do controle da constitucionalidade das leis, o problema é saber se o aspecto objetivo prevalece sobre o aspecto subjetivo: este controle, não importando a forma ou o procedimento utilizado, é pouco usado para dar satisfação diretamente aos indivíduos. Sua justificativa, e portanto sua legitimidade, consiste principalmente em preencher um certo número de funções de caráter geral, absolutamente indispensáveis para o bom funcionamento das instituições em um Estado moderno, e também para a promoção e a proteção dos direitos fundamentais". Cf. As Cortes Constitucionais, São Paulo: Landy Editora, 2004, pp. 35-36.

${ }^{254}$ Sobre a convergência dos sistemas de controle de constitucionalidade, é contundente a posição de Roger Stiefelmann Leal: "Na essência, as diferenças entre os modelos remanescem. Revelam esquemas institucionais diferentes, voltados à adequação entre o controle de constitucionalidade das leis e determinado ambiente político e cultural. A esse propósito, cabe destacar os métodos de composição da magistratura e sua compatibilidade com a jurisdição constitucional. Este aspecto demonstra, de maneira peculiar, a lógica intrínseca de cada modelo, atentando para a necessária implicação existente entre jurisdição constitucional e a específica legitimidade político-democrática de seus titulares. Ou os juízes são de carreira e a jurisdição constitucional é exercida por órgão externo ao Judiciário, legitimado por graduadas autoridades políticas - modelo europeu -, ou são escolhidos por processo político e a jurisdição constitucional por eles exercida - modelo norte-americano. A dicotomia clássica mantém-se, desse modo, íntegra e indispensável. Seu estudo, ademais, se mantém de extrema utilidade, pois permite, inclusive,
} 
órgão com as características de um Tribunal Constitucional, o legislador brasileiro tem priorizado a introdução de outros mecanismos para solucionar os problemas decorrentes da difusão de competência para apreciar a constitucionalidade de atos normativos, mecanismos estes que, em realidade, apenas mitigam os efeitos colaterais da correção individual das violações à igualdade constitucional. Trata-se, aqui, das técnicas processuais de vinculação aos precedentes judiciais, em especial aqueles emanados pelo Supremo Tribunal Federal.

No âmbito do controle concreto de constitucionalidade, o primeiro instituto voltado para a generalização das decisões proferidas é o conhecido mecanismo de resolução suspensiva da execução de leis declaradas inconstitucionais pelo Supremo Tribunal Federal, de competência do Senado Federal, tradição esta iniciada com a Constituição de $1934^{255}$. Essa competência do Senado para suspender, no todo ou em parte, a execução da lei declarada inconstitucional, tem por fundamento a possibilidade de se atribuir eficácia geral à decisão proferida no caso concreto, haja vista que, diferentemente do que ocorre no ambiente jurisdicional norte-americano, onde existe a regra do precedente judicial (stare decisis) ${ }^{256}$, as decisões prolatadas pelo Supremo Tribunal Federal em sede de controle concreto restringem-se às partes no processo ${ }^{257}$.

identificar características que, pedagogicamente, indicam as contradições e incongruências a que, nos dias de hoje, se sujeitam os denominados modelos mistos ou híbridos, que concedem a magistrados de carreira o exercício da jurisdição constitucional". Cf. "A convergência dos sistemas de controle de constitucionalidade: aspectos processuais e institucionais”. In: Revista de direito constitucional e internacional, $\mathbf{n}^{\mathbf{0}}$ 57, ano 14, n. 57, outubro-dezembro de 2006. São Paulo: Editora Revista dos Tribunais, 2006, p. 79.

${ }^{255}$ No mesmo sentido, afirma Elival da Silva Ramos: "a resolução do Senado suspensiva da execução de lei declarada inconstitucional pelo Supremo Tribunal Federal, que denotava a preocupação com a disfunção representada pela falta de uniformidade das decisões de controle pelo método incidental". Cf. Controle de constitucionalidade: perspectivas de evolução, p. 477.

${ }^{256}$ Vale consignar o entendimento de Elival da Silva Ramos: "a regra do precedente judicial (stare decisis), contudo, acaba por promover certa generalização dos efeitos da declaração casuística de inconstitucionalidade no sistema americano". Cf. Controle de constitucionalidade: perspectivas de evolução, p. 475.

${ }^{257}$ Sobre o assunto, expõe Luís Roberto Barroso: “A razão histórica - e técnica - da intervenção do Senado é singelamente identificável. No direito norte-americano, de onde se transplantara o modelo de controle incidental e difuso, as decisões dos tribunais são vinculantes para os demais órgãos judiciais sujeitos à sua competência revisional. Isso é válido inclusive, e especialmente, para os julgados da Suprema Corte. Desse modo, o juízo de inconstitucionalidade por ela formulado, embora relativo a um caso concreto, produz efeitos gerais. Não assim, porém, no caso brasileiro, onde a tradição romanogermânica vigorante não atribui eficácia vinculante às decisões judiciais, nem mesmo às do Supremo Tribunal. Desse modo, a outorga ao Senado Federal de competência para suspender a execução de lei inconstitucional teve por motivação atribuir eficácia geral, em face de todos, erga omnes, à decisão proferida no caso concreto, cujos efeitos se irradiam, ordinariamente, apenas em relação às partes do processo". Cf. O controle de constitucionalidade no direito brasileiro, pp. 109-110. 
Outra técnica, mais recente, que visa expandir os efeitos das decisões do Supremo Tribunal Federal proferidas em controle concreto e incidental de constitucionalidade, é o das súmulas vinculantes. De fato, o instituto trazido pela Emenda Constitucional 45, de 2004, permite ao tribunal a publicação de enunciados interpretativos que vinculem os demais órgãos do poder judiciário e da administração pública, sendo que os entendimentos jurisprudenciais aptos a embasar uma súmula vinculante podem advir, justamente, das decisões proferidas em controle concreto de constitucionalidade. Não por outra razão, hoje se entende que a resolução suspensiva do Senado já não se faz necessária, pois o tribunal é dotado de instrumento com igual força vinculante $^{258}$.

Por fim, pode-se citar o instituto processual da repercussão geral como um instrumento de generalização de interpretações constitucionais efetivadas em controle concreto. Embora a sua origem esteja fundada na ideia de se filtrar as demandas passíveis de conhecimento e processamento pelo Supremo Tribunal Federal, atualmente tanto a legislação processual civil - com seus dispositivos esparsos que determinam a imperiosidade de se aplicar o conteúdo decisório dos recursos extraordinários aos demais casos - quanto a própria jurisprudência do Supremo Tribunal Federal, indicam que as decisões proferidas em recurso extraordinário com repercussão geral são dotadas, ainda que implicitamente, de efeitos vinculantes sobre o poder judiciário ${ }^{259}$.

Apesar das técnicas expostas estarem fundadas em diversos valores, como o da celeridade processual e da segurança jurídica, é de se reiterar o seu papel

\footnotetext{
${ }^{258}$ É o que afirma Teori Albino Zavascki, quando comenta a redução da importância atribuída à resolução suspensiva do Senado: "Outra redução importante se deu a partir da regulamentação, pela Lei 11.417/2006, do art. 102-A da CF/1988, introduzido pela EC 45/2004, que autorizou o STF a editar súmulas vinculantes. A partir daí já não tem sentido prático eventual resolução do Senado suspendendo a execução de lei declarada inconstitucional se, sobre a matéria, houver súmula dessa natureza. Com efeito, a partir da publicação na imprensa oficial, a súmula, por si só, terá efeito vinculante em relação aos demais órgãos do Poder Judiciário e à administração pública direta e indireta, nas esferas federal, estadual e municipal (art. 103-A da CF), sendo que, 'da decisão judicial ou do ato administrativo que contrariar enunciado de súmula vinculante, negar-lhe vigência ou aplica-lo indevidamente, caberá reclamação ao STF, sem prejuízo dos recursos ou outros meios de impugnação". Cf. Eficácia das sentenças na jurisdição constitucional, $2^{\mathrm{a}}$ ed. São Paulo: Editora Revista dos Tribunais, 2012, p. 44.

${ }^{259}$ Tal característica é constatada por Roger Stiefelmann Leal: "A aplicação ampliativa da orientação adotada - uma única vez - em julgamento de recurso extraordinário pelas demais instâncias do Poder Judiciário não se restringe à sua parte dispositiva, mas alcança principalmente - como se constata - os seus fundamentos determinantes. Em outras palavras, implícita ao modelo da repercussão geral, tal como interpretado pelo STF, está a atribuição de efeito vinculante às decisões de mérito - únicas e avulsas proferidas em sede de recurso extraordinário". Cf. "A incorporação das súmulas vinculantes à jurisdição constitucional brasileira: alcance e efetividade em face do regime legal da repercussão geral e da proposta de revisão jurisprudencial sobre a interpretação do art. 52, X, da Constituição", in: Revista de direito administrativo, v. 261, Rio de Janeiro: Editora Forum, 2012, p. 189.
} 
uniformizador, consonante com os parâmetros da igualdade na aplicação do direito. Com razão, todos esses institutos estão voltados para a realização do direito de igualdade, porque se dedicam, antes de tudo, à equalizar a prestação do serviço jurisdicional, com o provimento de decisões substancialmente iguais para casos iguais $^{260}$.

\subsection{RePARAÇÃo Unilateral EM Controle AbSTrato}

\subsubsection{Características}

Concomitantemente ao sistema de controle incidental de constitucionalidade, cuja competência é difusa por todo o poder judiciário, o Brasil também adota algumas modalidades de controle de constitucionalidade cuja competência é privativa do Supremo Tribunal Federal ${ }^{261}$. Em nosso ordenamento, permite-se que determinadas autoridades proponham, diretamente a este tribunal, ações voltadas, exclusivamente, para o exame da constitucionalidade de atos normativos inferiores.

Em sua essência, as ações diretas acima descritas têm por objeto a análise da compatibilidade entre normas infraconstitucionais e normas constitucionais. Ou seja, diferentemente do que ocorre no campo do controle incidental, onde a questão da constitucionalidade consiste apenas num fundamento para a decisão concreta (questão

\footnotetext{
${ }^{260}$ Roger Stiefelmann Leal ressalta esse papel: "a sujeição dos demais poderes à Constituição e, por conseguinte, ao sentido que lhe empresta a jurisdição constitucional atua no sentido de eliminar eventuais divergências hermenêuticas, em nome dos princípios da segurança jurídica, da igualdade e da unidade da Constituição". Cf. $\mathbf{O}$ efeito vinculante na jurisdição constitucional, p. 114. No mesmo sentido, afirma Rodolfo de Camargo Mancuso: "Ao contrário do que possa parecer à primeira vista, o direito sumular não existe para exacerbar a função judicante, mas, antes, para coloca-la em parâmetros seguros, que impeçam o arbítrio e a injustiça ocorrentes quando respostas discrepantes são dadas a casos substancialmente análogos". Cf. Divergência jurisprudencial e súmula vinculante, p. 361.

${ }^{261}$ Acerca dessa convivência de modelos, comenta Gilmar Ferreira Mendes: "Finalmente, o controle misto de constitucionalidade congrega os dois sistemas de controle, o de perfil difuso e o de perfil concentrado. Em geral, nos modelos mistos defere-se aos órgãos ordinários do Poder Judiciário a prerrogativa de afastar a aplicação da lei nas ações e processos judiciais, mas se reconhece a determinado órgão de cúpula - Tribunal Supremo ou Corte Constitucional - a competência para proferir decisões em determinadas ações de perfil abstrato ou concentrado. Talvez os exemplos mais eminentes desse modelo misto seja o modelo português, no qual convivem uma Corte Constitucional e os órgãos judiciais ordinários com competência para aferir a legitimidade da lei em face da Constituição, e o modelo brasileiro, em que se conjugam o tradicional modelo difuso de constitucionalidade, adotado desde a República, com as ações diretas de inconstitucionalidade (ação direta de inconstitucionalidade, ação declaratória de constitucionalidade, ação direta de inconstitucionalidade por omissão e representação interventiva), da competência do Supremo Tribunal Federal". Cf. Curso de direito constitucional, p. 1.058 .
} 
prejudicial), o controle aqui examinado tem por objeto principal um pronunciamento sobre a própria lei, e sua validade no ordenamento jurídico. Por esta razão, entende-se que o controle realizado em processo principal é, também, abstrato, pois relacionado às normas em si, e não a conflitos de interesses entre partes antagônicas ${ }^{262}$.

Não se deve olvidar, nesse ínterim, que o controle abstrato de constitucionalidade encontra raízes no modelo europeu de jurisdição constitucional, cuja competência é monopolizada por Cortes ou Tribunais Constitucionais e, portanto, apartada da função jurisdicional ordinária, de competência do poder judiciário ${ }^{263}$. Por esta razão, costuma-se designar este modelo como de controle concentrado de constitucionalidade. Trata-se de um sistema que teve como precursor o Tribunal Constitucional austríaco, o qual foi instituído sob os auspícios do pensamento de Hans Kelsen, responsável por delinear um sistema especial de jurisdição constitucional, mais próximo da função legislativa (negativa) do que da função jurisdicional de resolução de $\operatorname{conflitos}^{264}$.

No que concerne à jurisdição constitucional da igualdade, o controle de constitucionalidade realizado em processo principal (controle abstrato) pode ser instrumentalizado para a correção de violações à igualdade de todas as espécies. Ao contrário do que ocorre no controle concreto, em que as demandas são ajuizadas com o objetivo de se obter uma vantagem comparativa, no controle principal os objetivos tendem a ser mais gerais e objetivos. É certo que, mesmo no âmbito do controle

\footnotetext{
${ }^{262}$ Vale citar a síntese de Luís Roberto Barroso: "O controle de constitucionalidade por ação direta ou por via principal, conquanto também seja jurisdicional, é um exercício atípico de jurisdição, porque nele não há um litígio ou situação concreta a ser solucionada mediante a aplicação da lei pelo órgão julgador. Seu objeto é um pronunciamento acerca da própria lei. Diz-se que o controle é em tese ou abstrato porque não há um caso concreto subjacente à manifestação judicial". Cf. O controle de constitucionalidade no direito brasileiro, p. 154.

${ }^{263}$ Essa separação é considerada uma das principais características do modelo, como demonstra a exposição de Louis Favoreu: "Uma jurisdição fora do aparelho jurisdicional. Esta é a diferença fundamental entre uma Corte Suprema e uma Corte Constitucional: enquanto a primeira está necessariamente - daí seu nome - colocada no cume de um edifício jurisdicional, a segunda está localizada fora de todo o aparelho jurisdicional". Cf. As Cortes Constitucionais, p. 33.

${ }^{264}$ A especialidade da jurisdição constitucional é destacada por Roger Stiefelmann Leal: "Em outras palavras, o juízo sobre a constitucionalidade das leis revela exercício de função de controle que naturalmente se situa acima do poder de legislar. A resolução dessa espécie de conflito normativo, portanto, aponta para o exercício de função que, diferentemente da jurisdição ordinária, não tem a lei como parâmetro ou limite insuperável. O objetivo principal da jurisdição constitucional é verificar a legitimidade jurídico-constitucional da atuação dos poderes públicos, especialmente do legislador, ao passo que a jurisdição ordinária visa, em primeiro lugar, solucionar, com base na lei, conflitos de interesse suscitados a partir de casos concretos". Cf. "O exercício da jurisdição constitucional pelo poder judiciário", in: Fernando Dias Menezes de Almeida; José Levi Mello do Amaral Júnior; Carlos Bastide Horbach (coord.); Direito Constitucional, Estado de Direito e Democracia. São Paulo: Quartier Latin, 2011, p. 599.
} 
abstrato, subsistem interesses diretos e indiretos no provimento jurisdicional que venha a declarar uma inconstitucionalidade. Isso, porém, não descaracteriza a natureza objetiva do controle, que em última instância se qualifica como um controle da legislação infraconstitucional em si.

Na perspectiva do controle abstrato, o escopo de uma ação pode ser tanto um incremento de vantagem, com a equiparação ou a diferenciação privilegiada de um regime jurídico em face de outro, quanto uma eliminação de privilégios incompatíveis com o direito de igualdade, com a equiparação de regimes mais benéficos a regimes ordinários ou com a diferenciação redutora de regimes jurídicos que, recebendo a incidência da igualdade proporcional, fazem jus a tratamento de menor alcance. Além disso, o regime jurídico em xeque pode ser tanto aquele a que eventualmente se submete o autor da ação, quanto um regime jurídico alheio, regulador de um grupo de indivíduos com o qual não mantém relação direta. Em suma, o controle principal pode ter como objeto toda e qualquer norma, ou relação internormativa, do ordenamento, porquanto sua função precípua é, como dito, resguardar o ordenamento como um todo, e não direitos subjetivos e específicos.

Diante dessas características, nota-se que as reparações feitas em controle principal ensejam maior flexibilidade, do ponto de vista processual, para os atores envolvidos no processo. De um lado, os autores das demandas, em regra, não se prendem a interesses jurídicos particulares, podendo questionar inconstitucionalidades sem um interesse jurídico direto no provimento ${ }^{265}$. Por outro lado, os julgadores detêm maior liberdade para conhecer da relação jurídica como um todo, não se limitando a resolver a questão da constitucionalidade em função do objeto concretamente pleiteado. É certo que, nalguma medida, o princípio processual da correlação entre pedido e sentença exerce influência sobre o controle principal. Entretanto, sua força é menor, haja vista as características objetivas e abstratas do controle exercido em processo principal.

Por aí se vê que, ao menos no atinente ao objeto da tutela, o controle abstrato é mais adequado à jurisdição constitucional da igualdade do que aquele

\footnotetext{
${ }^{265}$ A exigência de pertinência temática é exigida apenas das confederações sindicais e entidades de classe, como ensina Gilmar Ferreira Mendes: "Mencione-se, ainda, que, segundo a jurisprudência do Supremo Tribunal, há de se exigir que o objeto da ação de inconstitucionalidade guarde relação de pertinência com a atividade de representação da confederação ou da entidade de classe de âmbito nacional". Cf. Jurisdição constitucional, p. 166.
} 
exercido de modo concreto e incidental. Essa conclusão é inevitável quando se analisam as características acima descritas em cotejo com as propriedades normativas da igualdade, bem assim com os fundamentos da sua tutela judicial. Sendo o direito de igualdade um parâmetro jurídico metanormativo, seu objeto deve ser, acima de tudo, a coordenação de regimes jurídicos entre si. Em síntese: a aplicação do direito de igualdade deve voltar-se, por sua própria natureza de garantia objetiva na atribuição de direitos e obrigações, às normas infraconstitucionais em abstrato ${ }^{266}$.

Outra característica relevante da reparação unilateral efetuada em controle abstrato são os efeitos gerais do pronunciamento jurisdicional.

Como já se teve oportunidade de salientar, o controle de constitucionalidade efetuado em processo principal não se limita apenas às partes do processo, mas sim irradia seus efeitos para todos os possíveis destinatários da norma ${ }^{267}$. Em outras palavras, sua eficácia é contra todos, erga omnes, não necessitando de qualquer ato posterior, por parte do poder legislativo, que venha a retirar a norma do ordenamento, tornando-a inválida e incapaz de produzir efeitos. A decisão de inconstitucionalidade, por si só, tem o condão de expulsar do ordenamento a norma reputada incompatível com a Constituição ${ }^{268}$.

Dentre os fundamentos da eficácia erga omnes atribuída às decisões proferidas em controle abstrato de constitucionalidade, encontra-se a ideia de que tal função tem natureza semelhante ao ato de legislar, ainda que em sentido negativo, razão pela qual a atividade deve seguir as diretrizes de generalidade e abstração, típicas da

\footnotetext{
266 Vale citar a expressão de Jorge Miranda sobre o caráter objetivo do controle abstrato de constitucionalidade: "no tipo de garantia objectiva, a intervenção jurisdicional realiza-se à margem de um interesse pessoal, directo e legítimo na arguição de inconstitucionalidade. O que avulta é a constante conformidade das normas e dos actos com as normas constitucionais; tudo se dispõe para que os tribunais, a requerimento de outros órgãos, de agentes públicos ou de cidadãos, não deixem subsistir normas e actos desconformes". Cf. Contributo para uma teoria da inconstitucionalidade, p. 273.

267 A ese respeito, ensina Teori Albino Zavascki: "Declarando a constitucionalidade ou a inconstitucionalidade de um preceito normativo abstratamente considerado, a sentença proferida em ação de controle concentrado irradia efeitos para todos os possíveis destinatários da norma. Ou seja: a sentença tem eficácia subjetiva erga omnes". Cf. Eficácia das sentenças na jurisdição constitucional, p. 63.

${ }^{268}$ Vale citar as palavras de Luís Roberto Barroso: "Os limites subjetivos da coisa julgada na declaração de inconstitucionalidade não são controvertidos: sua eficácia é contra todos. A extensão erga omnes da autoridade da coisa julgada explica-se, doutrinariamente, por força do fenômeno da substituição processual, já mencionado. Não há necessidade, nesse caso, de suspensão da lei pelo Senado Federal, o que só ocorrerá na hipótese de decisão do Supremo Tribunal Federal em controle incidental (art. 52, X)". Cf. O controle de constitucionalidade no direito brasileiro, p. 179.
} 
atividade legislativa ${ }^{269}$. Assim, a mesma igualdade ínsita ao processo de regulação de condutas deve ser aplicada para os casos de reconhecimento e declaração de sua inconstitucionalidade, que deve valer para todos aqueles que, em tese, são regidos pela norma $^{270}$. Por esse motivo, inclusive, o modelo europeu caracteriza-se pela sanção de anulabilidade das normas inconstitucionais, e não de nulidade das mesmas, o que explica sua aproximação ao ideário de que a sanção equivale, nalguma medida, a uma revogação da norma, pois de caráter constitutivo-negativo, e não declaratório.

Pelas razões aduzidas, constata-se que os efeitos típicos do modelo abstrato de jurisdição constitucional propiciam uma reparação equilibrada das violações ao direito de igualdade. Em síntese, ela propicia que as interpretações jurisdicionais acerca do direito de igualdade sejam válidas para todos aqueles que se beneficiam das mesmas, independentemente de propositura e/ou êxito em demandas individuais.

Com as escusas de estilo pela aparente redundância, é possível afirmar que a reparação judicial em controle abstrato permite uma jurisdição $d a$ igualdade com igualdade, o que se coaduna aos ditames constitucionais, que estabelece a igualdade como parâmetro não apenas para a atividade legislativa, mas também para a jurisdicional.

\subsubsection{Dilemas}

O processo reparatório objetivo é dotado de características que o tornam indene das objeções enfrentadas pela reparação efetuada em processos subjetivos, como a estrita vinculação do provimento jurisdicional ao bem concretamente visado pelo autor da demanda, assim como a restrição dos efeitos decisórios apenas às partes que tomaram corpo no processo. Entretanto, a reparação unilateral via controle abstrato

\footnotetext{
${ }^{269}$ Oportuna a citação de Hans Kelsen: “Ora, anular uma lei é estabelecer uma norma geral, porque a anulação de uma lei tem o mesmo caráter de generalidade que sua elaboração, nada mais sendo, por assim dizer, que a elaboração com sinal negativo e portanto ela própria uma função legislativa". Cf. Jurisdição constitucional, pp. 151-152.

${ }^{270} \mathrm{Em}$ termos semelhantes, constata Rui Medeiros: "A eficácia erga omnes da declaração de inconstitucionalidade tem plena razão de ser. A força obrigatória geral pretende, no fundo, atribuir à declaração força ou vinculatividade paralela à da norma controlada. A força obrigatória geral da declaração de inconstitucionalidade é uma consequência do objeto da declaração: a norma contém uma regulamentação geral e abstracta e, por isso, a consequente declaração de inconstitucionalidade deve atingir as mesmas situações e pessoas abrangidas pela norma em causa". Cf. A decisão de inconstitucionalidade, p. $800-801$.
} 
também enfrenta dilemas que, peculiares à sua formatação processual, não são menos árduos de se solucionar.

O primeiro dos dilemas diz respeito à identificação da forma de inconstitucionalidade que se pretende reparar e, por conseguinte, do instrumento processual que deve ser empregado. Isto é, desafia a comunidade jurídica a escolha entre a ação direta de inconstitucionalidade por ação e a ação direta de inconstitucionalidade por omissão. A distinção conceitual entre os fenômenos da inconstitucionalidade por ação e por omissão já foi devidamente analisada neste trabalho, cabendo a este ponto apenas investigar os aspectos processuais relativos à opção entre os dois tipos de ação.

A dificuldade pode ser resumida da seguinte maneira: constatada e impugnada uma violação à igualdade constitucional, seja em decorrência de uma equiparação entre desiguais, seja em decorrência de uma diferenciação de iguais, devese questionar a inconstitucionalidade de uma omissão do legislador, que teria se omitido da missão de estabelecer regimes jurídicos condizentes com o direito constitucional de igualdade, ou então a ação do legislador, que teria estabelecido uma relação internormativa contrária a este direito? Desse primeiro questionamento decorre outro: o sujeito que se encontrar submetido a regime jurídico menos benéfico deveria impugnar a ausência de benefício enquadrando-o como omissão (ainda que parcial) do legislador, ou como ação discriminatória inconstitucional?

O dilema acima descrito advém de diversos fatores ${ }^{271}$. Em primeiro lugar, porque a existência de entendimentos divergentes pode, em tese, acarretar no não conhecimento da ação proposta, seja pelo fato de se ter impugnado uma ação onde o tribunal entende haver uma omissão, seja pelo contrário. Em segundo lugar, porque os pronunciamentos judiciais resultantes podem variar muito de acordo com o instrumento utilizado: enquanto a ação direta de inconstitucionalidade por omissão tende a ser empregada como um mecanismo de propulsão da atividade legislativa, a ação direta de inconstitucionalidade (por ação) tem o caráter de constrição e reprimenda da atividade desempenhada pelo legislador. Em outras palavras, enquanto o questionamento da

\footnotetext{
${ }^{271}$ Já se teve oportunidade de analisar essa controvérsia, no tópico 2.3.1 ("Inconstitucionalidade por ação ou por omissão"). Neste ponto foi ressaltado que, tanto no Brasil quanto em Portugal, países que adotam o instituto da inconstitucionalidade por omissão, é discutido se a ausência ou a insuficiência de regimes jurídicos configura ação ou omissão inconstitucional.
} 
omissão aproxima-se do objetivo de se obter mais direitos, a impugnação da ação pode acarretar na completa eliminação não apenas do regime objeto da ação, mas também daquele utilizado em comparação, hipótese esta que poderia resultar numa "reforma para pior" ${ }^{, 272}$. Por último, vale lembrar que os efeitos das ações são substancialmente distintos: se na ação direta de inconstitucionalidade por ação o tribunal pode declarar a nulidade do regime jurídico contestado, na ação direta por omissão ele se limita a comunicar o poder legislativo sobre a necessidade de se positivar novo regime jurídico.

Enfim, tanto pela questão do conhecimento, quanto pelas questões do resultado e dos efeitos da decisão, a escolha entre uma ação direta de inconstitucionalidade por ação (ADI) e uma ação direta de inconstitucionalidade por omissão (ADO) representa um importante dilema da reparação unilateral em controle abstrato.

Um segundo aspecto digno de nota refere-se à vinculação das decisões proferidas em controle abstrato, tanto com relação aos demais órgãos do poder judiciário, quanto aos demais poderes da República. Naquele caso, discute-se até que ponto uma atividade integrativa realizada pelo Supremo Tribunal Federal deve ser acatada pelos tribunais inferiores. No que concerne à vinculação dos demais poderes, questiona-se até que ponto uma decisão proferida em controle abstrato, cujo cumprimento exija substanciais dotações orçamentárias ou mesmo uma drástica alteração de programas governamentais, deve ser acatada pelos poderes políticos. A seguir, investiga-se este último ponto.

Já foi objeto deste estudo a admissibilidade do modelo unilateral de reparação das violações à igualdade constitucional, em especial a problemática da usurpação da função legislativa por parte dos órgãos jurisdicionais encarregados de interpretar e aplicar o direito constitucional de igualdade ${ }^{273}$. Àquela altura, verificou-se que o modelo unilateral somente é admissível quando preenchidos alguns requisitos, como a existência de uma relação de igualdade bem definida em nível constitucional, a suficiência da sanção de nulidade de um segmento normativo expresso para a

${ }^{272}$ A preocupação é verificada na obra de Gilmar Mendes: "Evidentemente, a cassação da norma inconstitucional (declaração de nulidade) não se mostra apta, as mais das vezes, para solver os problemas decorrentes da omissão parcial, mormente da chamada exclusão de benefício incompatível com o princípio da igualdade. É que ela haveria de suprimir o benefício concedido, em princípio licitamente, a certos setores, sem permitir a extensão da vantagem aos segmentos discriminados". Cf. Curso de direito constitucional, $4^{\text {a }}$ ed. São Paulo: Saraiva, 2009, p. 1.243.

${ }^{273}$ Item 3.3.2. 
restauração do estão de igualdade e a preservação de regimes gerais em detrimento de regimes especiais. Ausentes os requisitos, a correção jurisdicional é ilegítima. Do mesmo modo, também já foi ressaltado que fatores orçamentários podem vir a indicar a adoção do modelo reparatório bilateral.

A peculiaridade a ser destacada, no contexto da reparação através de controle abstrato, concerne aos drásticos efeitos que podem ter as decisões proferidas com extrapolação dos limites da atividade jurisdicional. Afinal, embora o controle de constitucionalidade em processo principal não padeça dos problemas de igualdade relativos à variação de entendimentos jurisprudenciais, vez que suas decisões possuem eficácia geral, ele pode gerar distorções mais patentes quanto à divisão de funções estatais, justamente por conta da sua força erga omnes. Isto é, se por um lado as decisões em controle abstrato não geram dificuldades de uniformização da jurisprudência, como ocorre em controle incidental, por outro lado elas podem acarretar em desequilíbrios na relação entre poderes, repercutindo sobremaneira nas funções de governo e planejamento ${ }^{274}$.

Suponha-se a propositura de uma ação direta de inconstitucionalidade com o propósito de se declarar a inconstitucionalidade de determinado programa governamental, pelo fato dele não prever tratamento privilegiado para determinados grupos considerados vulneráveis, que na visão do autor da demanda são dotados de desigualdades fáticas a serem compensadas. Imagine-se, por exemplo, o questionamento da constitucionalidade de um programa educacional que deixa de conferir bônus (ou quotas) para indivíduos pertencentes a classes sociais ou etnias historicamente discriminadas, ou então um programa de saúde que não trate com privilégio idosos e/ou pessoas com doença grave. Superando-se a questão de mérito sobre a constitucionalidade ou não das medidas, e partindo-se do pressuposto de que o julgador considera inconstitucionais as equiparações feitas, surge a questão: a declaração de

\footnotetext{
${ }^{274}$ A expansão do controle abstrato de constitucionalidade é apontada como fator propulsor do ativismo judicial por Elival da Silva Ramos: "Mas, cabe indagar por que o controle concentrado de constitucionalidade ou controle abstrato nos sistemas difusos induzem ao incremento do ativismos judicial. A principal razão para tanto está na maior proximidade do controle de constitucionalidade, assim efetuado, do exercício da função legislativa, ainda que se trate, como já assinalado, do exercício de função jurisdicional. Com efeito, quer em uma hipótese como noutra, a decisão judicial sobre a validade da lei é emitida com efeitos gerais, ou erga omnes; de outra parte, quer no controle concentrado, quer no controle abstrato em sistema difuso, registra-se a tendência a se admitir a modulação dos efeitos temporais das decisões sancionatórias da inconstitucionalidade; finalmente, a jurisdição constitucional, assim desenvolvida, interfere diretamente no conteúdo dos atos legislativos controlados". Cf. Ativismo judicial, p. 277.
} 
inconstitucionalidade gera que tipo de obrigações para o governo? Deveria o Supremo Tribunal Federal estipular as compensações necessárias para o cumprimento da decisão? A inexistência de previsão orçamentária prévia pode justificar o descumprimento da decisão? Essas e outras questões traduzem um dos dilemas mais profundos da reparação unilateral em controle abstrato.

Por último, é imperioso avaliar a força vinculante das reparações promovidas em controle abstrato sobre os demais órgãos do poder judiciário.

Noutra oportunidade, foram analisadas as chamadas sentenças manipulativas, entendidas como as decisões que não se limitam a sancionar de nulidade preceitos inconstitucionais, mas que vão além e modelam o sentido ou os efeitos da norma submetida a julgamento ${ }^{275}$. Sem prejuízo do estudo da manipulação dos efeitos temporais da decisão, feito de modo apartado, estudou-se a sentença manipulativa como uma modalidade decisória complexa, pois responsável por conjugar ablações normativas com operações reconstrutivas e/ou adjuntivas de conteúdo. Em síntese, destacaram-se as chamadas sentenças de efeitos aditivos ${ }^{276}$.

Nesse contexto, além da problemática de sua admissibilidade em face da separação de poderes e da liberdade de conformação do legislador, também deve ser mencionado o seguinte dilema: uma vez prolatada pelo Supremo Tribunal Federal uma sentença de efeitos aditivos, em que o tribunal agrega à sanção de nulidade uma diretriz interpretativa que, preenchendo a lacuna criada pela componente ablativa da decisão, acarreta na remodelação do sentido normativo originário, ficam os demais órgãos do poder judiciário vinculados à operação integrativa realizada pelo tribunal, ou poderia $\mathrm{o}$ órgão de base preencher a lacuna de outra forma? Em termos de igualdade, supondo-se que o tribunal supremo declare a nulidade de um determinado regime jurídico e, na mesma decisão, determine a aplicação, por analogia, do regime jurídico aplicável ao terceiro utilizado como parâmetro (tertium comparationis), ficam os tribunais e juízes

\footnotetext{
${ }^{275}$ Relembre-se a lição de Carlos Blanco de Morais: "Em contraponto a este tipo de decisões-regra, surgem as sentenças manipulativas ou decisões de 'carácter intermédio'. Em sentido lato, e abarcando apenas as decisões desta natureza existentes na ordem jurídica portuguesa, as sentenças manipulativas consistem em decisões jurisdicionais que determinam a modelação do sentido ou dos efeitos da norma submetida a julgamento". Cf. Justiça constitucional, tomo II, p. 240.

${ }^{276}$ Mais uma vez, a definição de Carlos Blanco de Morais: "São, em sentido lato, sentenças com efeitos aditivos, as decisões positivas de inconstitucionalidade de cujo conteúdo resulte, tanto um juízo de invalidade, como a indicação de uma norma ou de um princípio normativo que assegurem a criação de condições para que o direito que conformou o objeto da mesma sentença se compatibilize futuramente com a Constituição". Cf. Justiça constitucional, tomo II, p. 364.
} 
inferiores obrigados a aplicar a analogia feita pelo órgão judicial de cúpula, ou a vinculação se dá apenas com relação à invalidade declarada pelo tribunal?

Os questionamentos são relevantes à medida que, se por um lado a declaração de inconstitucionalidade é pacificamente reconhecida como de cumprimento obrigatório, em razão de sua eficácia erga omnes, não apenas para o poder judiciário, mas para as autoridades estatais como um todo, por outro lado a parte reconstrutiva da decisão não segue a mesma lógica ${ }^{277}$. Assim, é de se indagar qual a natureza dessa componente adjuntiva, bem como o grau de vinculação que ela implica aos demais órgãos aplicadores do direito, análise esta que deve ser feita à luz dos fundamentos do modelo abstrato de controle de constitucionalidade.

Como prova da relevância desse dilema, é oportuno advertir que o mesmo é contumaz em países europeus que adotam o sistema concentrado de constitucionalidade. $\mathrm{Na}$ Itália, por exemplo, são notórios os conflitos instaurados entre a Corte Constitucional e o Poder Judiciário, em especial no período em que aquele proferia sentenças de efeitos aditivos com frequência. Nos anos oitenta, quando a Corte era pródiga em pronunciar sentenças manipulativas, os órgãos do poder judiciário passaram a descumprir todo o conteúdo decisório que ia além do ato de eliminação de normas inconstitucionais. Isto é, por considerarem que à Corte não competia impor uma interpretação unívoca ao poder judiciário, mas apenas e tão somente expulsar do ordenamento normas inconstitucionais, os demais órgãos consideravam que a integração realizada pela Corte não era obrigatória. Por conta dessa recalcitrância, a Corte Constitucional passou a adotar as chamadas sentenças aditivas de princípio, cujo elemento adjuntivo consiste na indicação de um princípio a ser aplicado pelo poder judiciário, ou seja, representa elemento menos incisivo ${ }^{278}$.

\footnotetext{
${ }^{277}$ A provocação também é feita por Rui Medeiros: “Ora, se é indiscutível que a parte ablativa da decisão dispõe da eficácia própria das decisões de inconstitucionalidade em geral, outro tanto não se pode dizer em relação à parte reconstrutiva da decisão". Cf. A decisão de inconstitucionalidade, p. 478.

${ }^{278}$ Markus González Beilfuss retrata esse acontecimento: "Pero el desarrollo jurisprudencial de las sentencias aditivas de principio también puede ser interpretado, hasta cierto punto, como una rectificación de la tendencia iniciada en la década de los ochenta de limitar la presentación de cuestiones de inconstitucionalidad que buscan sentencias con efectos aditivos. En este sentido cabe destacar, en efecto, que en los últimos años la Corte Constitucional ha inadmitido muchas cuestiones de este tipo, alegando que los efectos aditivos solicitados incidirían en la discrecionalidad del legislador al no ser ni constitucionalmente obligados ni lógicamente necesarios". Cf. Tribunal Constitucional y reparación de la discriminación normativa, p. 207.
} 
Apesar de o Brasil não adotar o sistema concentrado de controle de constitucionalidade, é de se observar que a recalcitrância dos demais órgãos judiciais com relação a manipulações normativas eventualmente realizadas pelo Supremo Tribunal Federal é um dilema a ser enfrentado também aqui. Afinal, essa questão diz respeito à própria competência do Tribunal, seus limites e sua função, tema este que ganha relevo quando se trata da jurisdição constitucional da igualdade, afeita que é a sentenças manipulativas em geral.

A seguir, os dilemas acima expostos, atinentes ao instrumento processual de impugnação das violações à igualdade constitucional (ADI ou ADO) e à vinculação das decisões proferidas em controle abstrato, tanto com relação aos demais poderes da república, quanto com relação aos demais órgãos do poder judiciário, serão objeto de análise crítica.

\subsubsection{Crítica}

Dentre os dilemas confrontados pela via reparatória em controle abstrato, o primeiro deles (cabimento de ação direta de inconstitucionalidade por ação ou por omissão) pode ser solucionado com o reconhecimento da dificuldade como algo intrínseco à jurisdição da igualdade, e cuja importância deve ser relativizada. Por sua vez, os dilemas relativos à vinculação das decisões (em relação aos demais poderes da república e demais órgãos do poder judiciário) carecem de soluções mais substanciais, que refletem sobre a própria sistemática geral de jurisdição constitucional da igualdade.

Como solução para a dificuldade em se obter um consenso sobre a natureza da inconstitucionalidade verificada pela incompletude de regimes normativos, se por ação ou por omissão, é de se defender a existência de uma fungibilidade entre as ações diretas de inconstitucionalidade por ação e por omissão, em especial quando se tratar de omissões parciais $^{279}$. Para tanto, é adequado supor que, corriqueiramente, não é possível

\footnotetext{
${ }^{279}$ Vale citar a posição de Gilmar Mendes: "Dado que no caso de uma omissão parcial existe uma conduta positiva, não há como deixar de reconhecer a admissibilidade, em princípio, da aferição da legitimidade do ato defeituoso ou incompleto no processo de controle de normas, ainda que abstrato. Tem-se, pois, aqui, uma relativa, mas inequívoca fungibilidade entre a ação direta de inconstitucionalidade (da lei ou ato normativo) e o processo de controle abstrato da omissão, uma vez que os dois processos - o de controle de normas e os de controle da omissão - acabam por ter - formal e substancialmente - o mesmo objeto, isto é, a inconstitucionalidade da forma em razão de sua incompletude". Cf. Curso de direito constitucional, pp. 1.241-242.
} 
fazer uma clara distinção entre elas, haja vista que, nalgumas situações, convivem legislações positivadas e lacunas normativas, gerando confusão entre os institutos de controle $^{280}$.

Nada obstante o fato desta dificuldade decorrer de uma compreensão equivocada do fenômeno, é preciso ter em vista que a inexistência de consenso e clareza conceitual não deve impedir o acesso ao poder judiciário. Assim, é prudente que ações diretas propostas contra lesões à igualdade e designadas como ações de inconstitucionalidade por omissão (ADO) sejam recebidas, processadas e julgadas como se fossem ações diretas de inconstitucionalidade por ação (ADI) ${ }^{281}$.

A solução acima tem encontrado guarida na jurisprudência do Supremo Tribunal Federal, que vem mudando sua orientação quanto à fungibilidade entre ADIs e ADOs. Se em decisão de 1994 (ADI $986 \mathrm{MC}^{282}$ ), o tribunal afirmou a inviabilidade da conversão da ação direta de inconstitucionalidade em ação de inconstitucionalidade por omissão, em 2010, no julgamento da ADI $875^{283}$ (julgamento conjunto com as ADIs 1.987, 2.727 e 3.243), que questionavam a incompletude da Lei Complementar $n^{\circ}$ 62/89 por não ter fixado os critérios de rateio do Fundo de Participação dos Estados, o tribunal considerou que omissões parciais podem ser questionadas tanto pela via da ação direta de inconstitucionalidade por ação, quanto pela via da ação direta de

\footnotetext{
${ }^{280}$ O fenômeno é retratado por Paulo Paiva: "A aparente confusão entre os institutos de controle, que não lhes é ínsita, torna-se facilmente compreensível se se leva em consideração que, ao contrário da omissão absoluta, a parcial contém uma conduta legislativa positiva, que não pode ser excluída do processo de controle de normas". Cf. A fungibilidade entre ADI e ADO e as técnicas de decisão que resolvem omissões legislativa inconstitucionais parciais, p. 7.

${ }^{281}$ No mesmo viés, observa Paulo Paiva: "Em hipóteses que tais, parece despicienda a distinção entre as espécies de ações diretas de inconstitucionalidade, sobressaindo, ao contrário, a premência de encontrarse uma técnica de decisão adequada com a qual superar o alegado estado de inconstitucionalidade originado na omissão parcial do legislador". Cf. "A fungibilidade entre ADI e ADO e as técnicas de decisão que resolvem omissões legislativa inconstitucionais parciais", In: Observatório da Jurisdição Constitucional, Ano 3, 2009/2010, p. 7.

${ }^{282}$ ADI 986 MC / DF; Relator(a): Min. NÉRI DA SILVEIRA; Julgamento: 10/02/1994; Órgão Julgador: Tribunal Pleno.

${ }^{283}$ Neste caso, vale transcrever toda a ementa: Ações Diretas de Inconstitucionalidade (ADI n. ${ }^{\circ}$ 875/DF, ADI n. ${ }^{\circ}$ 1.987/DF, ADI n. ${ }^{\circ} 2.727 / \mathrm{DF}$ e ADI n. ${ }^{\circ} 3.243 / \mathrm{DF}$ ). Fungibilidade entre as ações diretas de inconstitucionalidade por ação e por omissão. Fundo de Participação dos Estados - FPE (art. 161, inciso II, da Constituição). Lei Complementar n ${ }^{\circ}$ 62/1989. Omissão inconstitucional de caráter parcial. Descumprimento do mandamento constitucional constante do art. 161, II, da Constituição, segundo o qual lei complementar deve estabelecer os critérios de rateio do Fundo de Participação dos Estados, com a finalidade de promover o equilíbrio socioeconômico entre os entes federativos. Ações julgadas procedentes para declarar a inconstitucionalidade, sem a pronúncia da nulidade, do art. $2^{\circ}$, incisos I e II, $\S \S 1^{\circ}, 2^{\circ}$ e $3^{\circ}$, e do Anexo Único, da Lei Complementar n. ${ }^{\circ} 62 / 1989$, assegurada a sua aplicação até 31 de dezembro de 2012. Cf. ADI 875 / DF; Relator(a): Min. GILMAR MENDES; Julgamento: 24/02/2010; Órgão Julgador: Tribunal Pleno.
} 
inconstitucionalidade por omissão, o que leva ao entendimento de que tais instrumentos são fungíveis entre si, no caso de omissões parciais.

O segundo dilema, relativo à vinculação (horizontal) dos demais poderes, legislativo e executivo, às correções proferidas em controle abstrato pelo Supremo Tribunal Federal, principalmente aquelas com acentuada repercussão sobre programas de governo, deve ser examinado com cautela. Não se cogita, aqui, a possibilidade de um puro e simples descumprimento de decisão judicial por discordância da autoridade governamental em face do conteúdo decisório produzido. Tampouco se trata aqui da hipótese de ineficácia da decisão por conta de suas repercussões financeiras e orçamentárias, como se a Constituição fosse subordinada a fatores econômicos, e não o contrário. O que se pretende destacar, em suma, é a inadequação de uma irrefletida interferência jurisdicional sobre atividades de planejamento e execução de políticas públicas, aspecto este que pode macular competências constitucionalmente reservadas aos poderes legislativo e executivo e, sobretudo, corre o risco de não ter condições de cumprimento integral.

Do ponto de vista orçamentário, sentenças que venham a estender direitos sob o fundamento de proteção ao direito de igualdade, notadamente aquelas que promovem a reconstrução do ordenamento (efeitos aditivos) em tema de direitos sociais, assistência social, remuneração do serviço público, previdência, entre outros, podem causar consequências relevantes para o equilíbrio orçamentário, principalmente na hipótese de controle abstrato, haja vista sua eficácia geral ${ }^{284}$. É o caso de decisões que conferem pensões a viúvos nos mesmos moldes daqueles conferidos às viúvas ${ }^{285}$, que estabelecem direitos equivalentes para servidores anteriormente diferenciados ${ }^{286}$, que incluem em programas educacionais, habitacionais, de saúde, entre outros, sujeitos que haviam sido excluídas, explícita ou implicitamente, pelo legislador, entre outros. Como

\footnotetext{
${ }^{284} \mathrm{O}$ assunto é comentado por Markus González Beilfuss: "En el ámbito del principio de igualdad, sin embargo, es evidente que las repercusiones económicas de las sentencias constitucionales pueden ser muy notables si la alteración de la relación internormativa que resulta de un fallo anulatorio afecta a prestaciones públicas o a normas tributarias de aplicación masiva”. Cf. Tribunal Constitucional y reparación de la discriminación normativa, pp. 76-77.

${ }^{285}$ É o que se decidiu nos seguintes acórdãos do Supremo Tribunal Federal: RE 415861/RS, Relator(a): Min. Dias Toffoli, Julgamento: 19/06/2012, Órgão Julgador: Primeira Turma; RE 607907/RS, Relator(a): Min. Luiz Fux, Julgamento: 21/06/2011; RE 429273 AgR/RJ, Relator(a): Min. Ayres Britto, Julgamento: 17/05/2011, Órgão Julgador: Segunda Turma; entre outros.

${ }^{286}$ É o caso do já citado RMS 22.306/DF, que determinou a equiparação de servidores civis e militares quanto ao reajuste da remuneração.
} 
denominador comum, todas elas são caracterizadas por uma expansão judicial de prestações públicas sem o prévio planejamento.

Diante disso, as questões colocadas são: considerando que, em casos envolvendo a temática dos programas sociais, seja constatado que um determinado grupo de sujeitos não foi incluído no âmbito daqueles que fazem jus a determinado benefício, poderia o órgão julgador estender o benefício a este grupo? $\mathrm{O}$ fato de tal decisão acarretar o aumento de despesas do Estado, as quais não tinham sido previstas, deve influenciar na decisão? Em que medida os poderes políticos ficariam vinculados à extensão determinada pelo tribunal?

As respostas podem variar de acordo com as circunstâncias do caso concreto, que deve ser avaliado à luz de todas as considerações feitas ao longo deste trabalho. No entanto, o que deve ser ressaltado, neste contexto, é o fato de que o direito de igualdade constitucional não corresponde a um suposto direito a extensão de benefícios. Não se deve olvidar que, à luz do direito de igualdade, também a redução do alcance normativo de grupos privilegiados ao patamar daqueles que se encontram em situação inferior satisfaz plenamente o direito de igualdade (aplicado na condição de igualdade paritária ou proporcional entre iguais). Do mesmo modo, seria constitucional a eventual equiparação de ambos em nível menor ou maior do que aqueles originalmente previstos.

Em suma, sentenças desse jaez podem vir a provocar uma série de dificuldades para seu devido cumprimento, a ponto de gerar relutância dos poderes políticos, ou mesmo impossibilidade fática. Como resultado, haveria um desarranjo institucional que, antes de tudo, seria prejudicial à própria Constituição, não só porque uma decisão judicial não seria integralmente cumprida, mas sim porque a própria força normativa da Constituição ficaria em xeque.

O ponto a ser ressaltado, enfim, é o de que a definição de programas sociais pertence aos poderes submetidos à responsabilidade política (legislativo e executivo), os quais têm plenas condições de planejar suas ações e destinar os recursos necessários para tanto. Por sua vez, o Supremo Tribunal Federal não detém as ferramentas necessárias para a implementação de um programa que, na sua visão, é exigido pela Constituição. O direito de igualdade, por si só, não é uma ferramenta apta a 
fundamentar uma remodelação dos programas socais ${ }^{287}$. Diferentemente, ela permite somente o rechaço de alguma incompatibilidade com o direito de igualdade. A efetiva correção da afronta deve ser resguardada aos poderes políticos, que gozam de capacidade técnica e legitimidade constitucional para tanto.

Por último, deve ser examinado o dilema referente à vinculação (vertical) das sentenças proferidas pelo Supremo Tribunal Federal em sede de reparação via controle abstrato de constitucionalidade. Em síntese, o tema pode ser alinhado da seguinte forma: em que medida as reconstruções normativas feitas em sentenças de efeitos aditivos vinculam a tarefa de aplicação do direito por parte dos demais órgãos do poder judiciário?

Para responder à questão, é preciso conhecer um pouco do chamado efeito vinculante das decisões tomadas em controle abstrato, principalmente a sua extensão.

Para além da eficácia erga omnes das decisões de inconstitucionalidade feitas em controle abstrato, impera a regra de que as mesmas são dotadas de efeito vinculante. Diferenciando-se da ideia de eficácia geral, que tradicionalmente abarcou os dispositivos das sentenças, o efeito vinculante pode ser definido como a transcendência dos motivos determinantes da decisão, a sua ratio decidendi ${ }^{288}$. O objetivo fundamental do instituto é evitar a recalcitrância no cumprimento da decisão, proibindo-se a reincidência do comportamento inconstitucional, haja vista que a decisão passa a vincular não apenas na medida de declara ou não a inconstitucionalidade de determinado dispositivo, mas também em razão dos motivos, princípios e interpretações que lhe servem de fundamento ${ }^{289}$.

\footnotetext{
${ }^{287}$ Ao tratar da concretização de princípios constitucionais, assevera Elival da Silva Ramos: "É nesse ponto que se deve explicitar a existência de importante limitação à atuação concretizadora da Constituição pelo Poder Judiciário: as normas de desdobramento ou de expansão de princípios constitucionais, precisamente por não estarem compreendidas no respectivo campo de incidência, tal qual inicialmente proposto pelo Constituinte, devem ser formuladas pelo Poder Legislativo, o qual se sujeitará, como só acontecer com toda regulação subalterna, ao controle judicial a posteriori, típico de nosso sistema de fiscalização de constitucionalidade". Cf. Ativismo judicial, p. 186.

${ }^{288}$ Vale citar a definição de Roger Stiefelmann Leal: "Com a finalidade de não confundir o efeito vinculante com os demais efeitos e qualidades produzidos pelas decisões proferidas em controle abstrato de constitucionalidade, notadamente a coisa julgada oponível erga omnes, cumpre compreender o instituto como eficácia que transcende a parte dispositiva da decisão de modo a alcançar a sua ratio decidendi”. Cf. O efeito vinculante na jurisdição constitucional, p. 186.

${ }^{289}$ Cite-se, novamente, Roger Stiefelmann Leal: "Em alguns países europeus, não afeitos propriamente à prática construtivista do stare decisis, percebeu-se a necessidade de reforçar a eficácia das decisões prolatadas no âmbito da jurisdição constitucional, de modo que os demais poderes do Estado, inclusive os tribunais e a administração pública, estivessem vinculados não só à parte dispositiva da sentenças, mas
} 
A dúvida que surge, nesse contexto, é se a ratio decidendi refere-se apenas aos motivos que determinaram a declaração de inconstitucionalidade, ou se ela se aplica, outrossim, à componente adjuntiva da decisão.

Sob pena de se violar uma regra de competência consagrada, qual seja, a de que as decisões judiciais produzidas em processos principais se voltam para a desconstituição de atos normativos incompatíveis com a Constituição, e não para transformação de sentidos normativos gerais e abstratos, é de se reconhecer na parte aditiva das sentenças constitucionais apenas uma proposta de interpretação, cujo valor é estritamente persuasivo ${ }^{290}$, e não vinculante.

Conforme amplamente assinalado no decorrer deste trabalho, a função da jurisdição constitucional, especialmente quando se trata de controle abstrato, é somente a de expulsar do ordenamento aqueles preceitos que não se harmonizam com a Constituição, nos moldes de um legislador negativo. Assim, embora os fundamentos dessa declaração de invalidade vinculem os demais órgãos do poder judiciário, isso não ocorre com a parte decisória que impõe um novo sentido normativo para o preceito extirpado do ordenamento ${ }^{291}$. A vinculação, enfim, deve se limitar aos fundamentos que ensejaram a declaração de inconstitucionalidade, e não as reconstruções paralegislativas do órgão judicial de cúpula.

também aos motivos, princípios e interpretações que lhe serviram de fundamento, ou, como preferem Bocanegra Sierra e Klaus Bogel, à norma concreta de decisão. A imposição da ratio decidendi que presidiu a decisão aos demais poderes teria como efeito normativo necessário a proibição do uso do expediente da reiteração do comportamente julgado inconstitucional, bem como a obrigação de eliminar os demais atos que encerram o mesmo vício apontado. Este acréscimo eficacial denominou-se efeito vinculante (Bindungswirkung). Cf. O efeito vinculante na jurisdição constitucional, p. 113.

${ }^{290}$ Nesse sentido, Rui Medeiros: “Ora, da mesma forma que o Tribunal Constitucional não pode impor aos demais uma determinada interpretação conforme à Constituição, também não lhe é permitido fixar com eficácia vinculativa a solução que resulta da interpretação actualista da parte remanescente da lei. A parte aditiva da sentença vale, portanto, como proposta hermenêutica om valor apenas persuasivo, não havendo fundamento constitucional para admitir uma posição aristocrática do Tribunal Constitucional nesta matéria". Cf. A decisão de inconstitucionalidade, p. 479.

291 Ao comentar a força obrigatória geral das declarações de inconstitucionalidade em fiscalização abstracta sucessiva, Carlos Blanco de Morais faz a seguinte ponderação: "Semelhante imperatividade só vincula em relação à inconstitucionalidade declarada, e não em relação a segmentos aditivos das sentenças, como injunções, recomendações e preenchimento de lacunas". Cf. Justiça constitucional, tomo I, p. 239. 


\subsection{REPARAÇÃo BILATERAL}

\subsubsection{Características}

Analisados alguns aspectos processuais relativos ao modelo reparatório unilateral, onde vigoram as já consagradas modalidades de controle de constitucionalidade concreto e abstrato, é hora de se examinar os elementos processuais envolvidos no método de controle de constitucionalidade aqui referenciado como modelo reparatório bilateral.

Como visto anteriormente ${ }^{292}$, existem razões institucionais que aconselham, em determinadas situações, o envolvimento do poder legislativo no processo de reparação das violações à igualdade constitucional. Dentre estes motivos estão: a necessidade de se evitar um vazio normativo na regulamentação de determinada matéria (horror vacui), a inexistência de uma solução unívoca e definitiva no texto constitucional, a inadequação de um comportamento jurisdicional que se revista das características de legislador positivo, a eventual incidência de consequências orçamentárias relevantes, entre outros.

Diante das dificuldades encontradas, foram descritas as linhas gerais de um modelo reparatório dialógico, que teria por fundamento essencial a legitimidade do poder legislativo para avaliar as circunstâncias fáticas que envolvem uma lesão ao direito constitucional de igualdade e, a partir dessa análise, promover reforma legislativa de modo a positivar novo regramento jurídico compatível com este direito. Tal como afirmado outrora, o teste de igualdade envolve o complexo exame da coerência lógica entre vários elementos, como sujeitos, critérios e finalidades, assim como do equilíbrio na atribuição de direitos e obrigações, aspectos estes que nem sempre estão predeterminados em nível constitucional, daí a existência de certo espaço para a conformação legislativa do direito de igualdade.

Em síntese, a reparação bilateral envolve procedimentos evocativos e impulsionadores da atuação do poder primacialmente legitimado a criar direitos e obrigações, qual seja, o poder legislativo. Destarte, contém cinco etapas básicas: (i) reconhecimento judicial de uma violação à igualdade constitucional cuja resolução não está ao alcance do poder judiciário, não só por questões funcionais, mas eventualmente

\footnotetext{
${ }^{292}$ Tópico 3.4.
} 
também por conta de limites processuais; (ii) a suspensão da sanção de nulidade por determinado prazo de tempo considerado suficiente para a promulgação de novo regime jurídico compatível com a igualdade; (iii) o pronunciamento de decisão transitória que regerá a situação controvertida durante o prazo concedido ao poder legislativo; (iv) a comunicação ao poder legislativo da decisão; (v) decisão final do tribunal, após o esgotamento do prazo, acerca do nova legislação eventualmente aprovada pelo legislador, ou sobre a inércia do mesmo. A seguir, cada uma delas é analisada com maior profundidade.

A primeira fase completa-se com duas constatações. A primeira delas é a própria identificação do vício de inconstitucionalidade por violação ao direito de igualdade. Neste momento, verifica-se que uma determinada relação internormativa está em desacordo com a igualdade, seja por haver equiparado desiguais, ou por ter diferenciado iguais. Nada de novo, portanto. A complexidade surge na constatação seguinte, de que a sanção de nulidade de um ou alguns dos dispositivos envolvidos não terá o condão de restabelecer o estado de igualdade, ou mesmo de que a igualdade pode ser restabelecida de diversas formas, não havendo uma solução predefinida pela Constituição. Em suma, constata-se que a correção da afronta requer uma legislação positiva, a qual não pode ser ofertada pelo poder judiciário. Diante desta hipótese, uma visão tradicional da questão poderia indicar que a única saída é a extinção do processo por impossibilidade jurídica do pedido ${ }^{293}$, hipótese este que encontraria respaldo na lógica por trás da súmula 339 do Supremo Tribunal Federal ${ }^{294}$, já comentada. Entretanto, o modelo reparatório bilateral recomenda solução distinta, analisada em seguida.

Ao invés de extinguir o processo, hipótese esta que culminaria na permanência da inconstitucionalidade no ordenamento, o modelo bilateral propõe a

\footnotetext{
${ }^{293}$ Há decisões do Supremo Tribunal Federal no sentido de que o impedimento do poder judiciário atua $\mathrm{r}$ como legislador positivo enseja uma decisão pela "impossibilidade jurídica do pedido". Como exemplo, vale citar a decisão proferida no RE 370590 AgR/RJ (Relator: Min. Eros Grau, Julgamento: 29/04/2008, Órgão Julgador: Segunda Turma), cuja ementa diz: "A declaração de inconstitucionalidade dos textos normativos que estabelecem distinção entre as alíquotas recolhidas, a título de contribuição social, das instituições financeiras e aquelas oriundas das empresas jurídicas em geral teria como conseqüência normativa ou a equiparação dos percentuais ou a sua supressão. Ambas as hipóteses devem ser afastadas, dado que o STF não pode atuar como legislador positivo nem conceder isenções tributárias. Daí a impossibilidade jurídica do pedido formulado no recurso extraordinário. Agravo regimental a que se nega provimento". No mesmo sentido, cite-se o RE 402.728 AgR/PE (Relator: Min. Eros Grau, Julgamento: 22/04/2008, Órgão Julgador: Segunda Turma).

${ }^{294}$ Súmula 339: Não cabe ao Poder Judiciário, que não tem função legislativa, aumentar vencimentos de servidores públicos sob fundamento de isonomia.
} 
utilização da técnica da modulação para o futuro dos efeitos temporais da decisão de inconstitucionalidade. Ao fazer uso deste instrumental, cuja possibilidade é expressamente permitida no ordenamento pátrio, o poder judiciário pode suspender a sanção de nulidade por um determinado período de tempo que, em sua visão, propicia uma reforma dos regimes jurídicos por parte do poder competente, qual seja, o poder legislativo. Com isso, a identificação do vício de inconstitucionalidade passa a ser mero ponto de partida para um procedimento reparatório baseado na cooperação entre os poderes para o restabelecimento do estado de igualdade ${ }^{295}$, solução esta que, além de harmonizar regras constitucionais substantivas (direito de igualdade) e regras procedimentais (separação de poderes), atenua os riscos inerentes à criação imediata de um vazio jurídico ${ }^{296}$.

Antes, porém, de suspender os efeitos da decisão e estipular o prazo dentro do qual o poder legislativo deverá reparar a inconstitucionalidade, caberá ao órgão judicial estabelecer as regras transitórias que deverão vigorar durante o período designado para reforma. Afinal, seu comportamento implicará, necessariamente, numa dúvida para os aplicadores do direito: se as normas declaradas inconstitucionais, mas ainda não sancionadas, permanecem válidas e aplicáveis até o esgotamento do prazo, ou não ${ }^{297}$. Nesse contexto, será etapa natural do processo reparatório bilateral a definição do regime transitório, ainda que esta solução seja objeto de controvérsias.

\footnotetext{
${ }^{295}$ A solução é destacada por Markus Gonzáles Beilfuss: "Como pone de manifesto la experiencia de los diversos Tribunales Constitucionales analizados, el restablecimiento compartido de la igualdad puede articularse técnicamente de diversos modos. En qualquier caso, la sentencia que detecta la discriminación normativa no debe restablecer la igualdad por sí misma como en el modelo unilateral, sino que debe constituir el punto de partida de un proceso que finaliza con la reparación de la discriminación normativa por parte del legislador". Cf. Tribunal Constitucional y reparación de la discriminación normativa, pp. $181-182$.

${ }^{296}$ Este perigo já era tratado por Hans Kelsen nos primórdios do modelo europeu de controle de constitucionalidade: "Resulta da anulação, por assim dizer, um vazio jurídico. A matéria que era até então regulada deixa de sê-lo; obrigações jurídicas desaparecem; segue-se a liberdade jurídica. Poderão resultar daí consequências desagradabilíssimas. Sobretudo se a lei não foi anulada por causa do seu conteúdo, mas apenas por causa de um vício de forma qualquer que se produziu quando da sua elaboração, em particular quando a elaboração de uma lei para regular o mesmo objeto requer um prazo muito longo. Para remediar esse inconveniente, é bom prever a possibilidade de diferir a entrada em vigor da sentença de anulação até a expiração de certo prazo a contar da sua publicação". Cf. Jurisdição constitucional da igualdade, pp. 171-172.

${ }^{297}$ A dúvida é salientada por Markus González Beilfuss: "Las sentencias constitucionales que no reparan la discriminación directamente, sino que se limitan a dar origen a um proceso que culmina con el restablecimiento de la igualdad por parte del legislador, plantean de forma inmediata el problema de cuál deba ser la suerte del régimen jurídico discriminatorio hasta la aprobación de la ley reparadora. Durante este periodo interino, en efecto, los operadores jurídicos se encuentran en una situación cuanto menos peculiar: por un lado, una sentencia constitucional ha determinado con carácter vinculante que un régimen jurídico concreto es discriminatorio; pero por otro, dicha sentencia no provoca su expulsión ope legis del
} 
Em se tratando de igualdade, a decisão jurisdicional que exorta o legislador a positivar nova legislação sobre a matéria deve vir, em regra, com a indicação de critérios que indiquem as soluções possíveis, seja para guiar a reforma a ser feita pelo legislador, seja para guiar a aplicação das normas durante o período interino. Trata-se, portanto, de uma decisão que não deve se restringir a declarar a inconstitucionalidade de uma norma infraconstitucional e suspender seus efeitos até que se ultime a aprovação de novo regime jurídico pelo legislador. Nestas ocasiões, é adequado que o órgão de jurisdição constitucional faça a indicação de um critério normativo que deve pautar a reconstrução legislativa do ordenamento ${ }^{298}$. No caso do direito de igualdade, tais decisões devem vir acompanhadas de uma mensagem (explícita ou implícita) sobre o sentido de igualdade a ser resguardado, ou seja, sobre a necessidade de tratamentos equiparados ou diferenciados entre os sujeitos envolvidos na questão.

O fenômeno acima tem recebido, por influência da doutrina e da jurisprudência italianas, a denominação de sentenças aditivas de princípio, conforme já ressaltado. Inserida na esfera das sentenças manipulativas em sentido amplo, as sentenças aditivas de princípio podem ser consideradas uma derivação menos drástica das sentenças aditivas em sentido estrito. É certo que ambas são qualificadas pelo fato de agregarem uma componente reconstrutiva ao recorte sancionatório feito pelo órgão judicial. A diferença é que, enquanto nas sentenças aditivas em sentido estrito o julgador finaliza a operação integrativa de forma incisiva, nas sentenças aditivas de princípio ele se resigna a indicar o princípio a ser aplicado na matéria. Todavia, não

ordenamiento jurídico ni restablece directamente la igualdad, sino que, en función de la técnica empleada, retrasa la entrada en vigor de la inconstitucionalidad, declara la mera inconstitucionalidad de dicho régimen jurídico, o su ilegitimidad constitucional 'en cuanto excluye' un determinado principio". Cf. Tribunal Constitucional y reparación de la discriminación normativa, pp. 239-240.

${ }^{298}$ Essa prática, muito comum no direito italiano, é comentado por Roberto Romboli da seguinte maneira: "la Corte Constitucional, sujeta a la necesidad de respetar la discrecionalidad del legislador, en cuanto que su intervención sea considerada indispensable y no sustituible y no atente, en caso de inactividad del Parlamento, a su propia naturaleza de garante de la legitimidad constitucional de las leyes y de los derechos fundamentales de los ciudadanos constitucionalmente tutelados, ha adoptado, recientemente, un nuevo tipo de decisión, todavía no definida completamente en sus detalles, en la cual se sigue la misma técnica que en las sentencias aditivas ya señaladas, con la diferencia que, en este supuesto, no se introduce una norma inmediatamente eficaz y aplicable, sino que viene fijado un principio general que debe ser actuado mediante una actuación del legislador y al cual puede hacer referencia, con ciertos límites, el juez en la decisión de los casos concretos. Este tipo de pronunciamento esboza una espécie de colaboración entre la Corte, el Parlamento y los jueces, cada uno de los cuales debe actuar en el ámbito de las competencias que le son encomendadas por el ordenamiento". Cf. El control de constitucionalidade de las leyes em Italia, p. 194. 
define de modo preciso como o princípio deve regular a questão ${ }^{299}$, relegando esta missão tanto para o legislador, quanto para os demais aplicadores do direito.

Todo o procedimento descrito será exitoso caso o poder legislativo cumpra as determinações feitas pelo órgão judicial competente e promova uma reforma da legislação anteriormente considerada inconstitucional. No entanto, é possível que o apelo ao legislador não surta efeitos e este permaneça inerte, hipótese em que o tribunal será colocado numa situação delicada. Eis aqui um dilema a ser enfrentado pelo modelo reparatório bilateral, que se por um lado contém qualidades funcionais exemplares, por outro lado não pode ser considerado um modelo insuscetível de graves dificuldades. A seguir, este e outros dilemas são analisados.

\subsubsection{Dilemas}

Até aqui se procurou demonstrar quais são as características do processo de reparação bilateral de violações à igualdade constitucional. Tendo por fundamentos institucionais a impossibilidade de reparação direta pelo judiciário, bem assim o resguardo da liberdade de conformação do poder legislativo, a reparação bilateral é realizada através de mecanismos processuais como a modulação dos efeitos temporais para o futuro, o apelo ao legislador para que promulgue novo regime compatível com o direito de igualdade, a definição do regime a ser aplicado durante o prazo, entre outros.

Feita a análise descritiva, inicia-se nova etapa do estudo cujo objeto é a identificação dos dilemas processuais enfrentados pelo modelo reparatório bilateral. Afinal, embora esta sistemática atenda a determinadas condições processuais eventualmente existentes no âmbito da jurisdição constitucional da igualdade, como a necessidade de positivação de um regime com eficácia geral e a necessidade de reconstruir toda a relação internormativa impugnada, indo além do objeto da demanda, é

\footnotetext{
${ }^{299}$ Nesta altura, é oportuno reproduzir a opinião de Carlos Blanco de Morais: "Consideramos, pelo nosso lado, que as chamadas decisões aditivas de princípio não são, efetivamente, sentenças aditivas em sentido estrito, já que carecem de uma componente reconstrutiva plena que proceda, directa e imediatamente, à reparação de uma lacuna técnica ou axiológica ínsita numa norma que por elas tenha sido julgada parcialmente inconstitucional. Ainda assim, integram-se no tipo mais amplo das decisões com efeitos aditivos, já que nestas, de acordo com a definição dada, as decisões de inconstitucionalidade ou reparam directamente ou 'criam condições para a reparação' de um cenário de inconstitucionalidade entretanto declarada. No caso presente, a componente reconstrutiva da sentença é incompleta: não indica uma norma self executing, mas enuncia, ao invés, uma simples base ou princípio que carece de mediação do legislador ou do aplicador judicial". Cf. Justiça constitucional, tomo II, pp. 400-401.
} 
preciso salientar que este regime não é indene de dificuldades e também apresenta, tal como os sistemas de reparação unilateral, dilemas de difícil solução.

O primeiro dilema a ser elucidado diz respeito ao regime transitório, vale dizer, ao regime jurídico que deverá vigorar pelo período estipulado ao legislador para promulgação de nova legislação, consonante com o direito de igualdade. Em síntese, a questão que se coloca é se, nesse período, as relações jurídicas devem continuar submetidas à legislação declarada inconstitucional (embora não sancionada de nulidade), se esta deve ser considerada sem eficácia desde então, ou ainda se caberá ao órgão judicial definir um regime jurídico específico de transição.

Mais do que um dilema sobre reparação de afrontas ao direito de igualdade, o questionamento supra é decorrência do próprio instituto da modulação de efeitos para o futuro. Afinal, esta modulação implica, naturalmente, na manutenção de regimes inconstitucionais no ordenamento jurídico, o que não parece ser, à primeira vista, o mais adequado quando se trata de controle de constitucionalidade ${ }^{300}$. Afinal, tal sistemática não se compatibiliza nem com a modelo estadunidense de efeitos declaratórios ex tunc, nem com a de efeitos constitutivos negativos ex nunc, originária do modelo europeu. Por outro lado, a eventual restrição da eficácia dos dispositivos impugnados configuraria a própria resolução da questão, o que reduziria a própria utilidade do apelo ao legislador.

O segundo, e mais importante, dilema a ser tratado diz respeito ao grau de vinculação que possui uma sentença constitucional que exorta o poder legislativo a positivar novo regime compatível com a igualdade. Uma vez feito o apelo ao legislador, estaria este obrigado a cumprir as determinações advindas do órgão de controle? Em caso de descumprimento, caberia ao julgador pura e simplesmente declarar a inconstitucionalidade de todo o arcabouço normativo questionado, ou deveria substituir o legislador e prolatar uma sentença manipulativa com ares de legislação positiva? Seria possível aplicar alguma sanção ao poder recalcitrante?

\footnotetext{
${ }^{300}$ É o que salienta Markus González Beilfuss: "Detectada una norma inconstitucional por parte del Tribunal Constitucional y remitida su reparación al legislador, la consecuencia jurídica más lógica es que dicha norma no pueda seguir siendo aplicada durante el periodo interino. (...) Aunque como se ha señalado anteriormente, una interpretación sistemática de la Constitución impide otorgar a esta regla rango constitucional, la impossibilidad de seguir aplicando una norma que ha sido declarada inconstitucional por el Tribunal Constitucional parece constituir la consecuencia más coherente con la eficacia del proprio control de constitucionalidad". Cf. Tribunal Constitucional y reparación de la discriminación normativa, pp. 241-242.
} 
Sabe-se que, na estrutura constitucional de divisão dos poderes, não há hierarquia entre quaisquer destes, que são independentes entre si. O que existe, como consequência de uma tradição secular inaugurada no constitucionalismo norteamericano, é uma relação de freios e contrapesos entre os mesmos. Assim, embora não sejam permitidas ingerências de um poder sobre o outro, é possível afirmar que a própria divisão funcional induz a um controle recíproco. No que tange à relação entre o poder judiciário e o poder legislativo, a competência daquele para rechaçar a validade de atos legislativos contrários à Constituição constitui uma forma de limitar o poder parlamentar. No entanto, reitere-se, tal prerrogativa não constitui um poder disciplinar ou correcional típicos de uma relação hierárquica.

Tratando-se, portanto, de uma relação de independência com controle recíproco decorrente do exercício das próprias funções, não competindo ao poder judiciário impor uma solução específica ao poder legislativo, a sentença constitucional que suscite do poder legislativo para que restaure o estado de igualdade corre o risco de tornar-se ineficaz. Daí o impasse.

Suponha-se uma sentença constitucional que, constatando uma contrariedade ao direito de igualdade, verifique também que a reparação somente pode ser feita pelo poder legislativo, pois se encontra além dos seus limites funcionais e processuais. Neste caso, surge o modelo bilateral como uma solução interessante e condizente com as normas constitucionais procedimentais, motivo pelo qual determina o órgão judicial que o poder legislativo promulgue novos regimes jurídicos que respeitem a igualdade constitucional, seja promovendo a equiparação de sujeitos aritmeticamente iguais, seja construindo uma diferenciação de sujeitos proporcionalmente iguais. Ultrapassado um período de tempo razoável, ou mesmo um período estabelecido pelo poder judiciário, sem que o poder legislativo tenha promulgado as normas requeridas, o que deve fazer o poder judiciário?

Nesse contexto, depreende-se que o modelo bilateral, embora satisfatório do ponto de vista funcional, apresenta dificuldades do ponto de vista da sua eficácia e vinculação. Do mesmo modo que ao poder judiciário não compete legislar positivamente, também não lhe compete determinar a pauta do congresso nacional.

Mas não só o descumprimento total da determinação judicial gera um dilema de difícil solução. Também o descumprimento parcial, resultante de uma 
reforma incompleta ou insuficiente da legislação inconstitucional, representa dilema contundente para o modelo reparatório bilateral. Suponha-se que, diante de um caso específico de afronta ao direito de igualdade, ocasionada pela exclusão de alguns grupos no usufruto de um benefício legal, o Supremo Tribunal Federal decida instaurar o processo bilateral, suspendendo a sanção de nulidade por determinado período e remetendo à questão ao Congresso Nacional, para que este promova uma reforma legislativa no sentido de eliminar a diferenciação dos grupos excluídos. Imagine-se que, na circunstância, o poder legislativo retire a cláusula excludente de alguns grupos envolvidos, mas não de todos, de sorte que a reconfiguração normativa seja apenas parcialmente satisfatória. O que deve fazer o tribunal?

Essas e outras questões ensejam algumas respostas, esboçadas a seguir.

\subsubsection{Crítica}

O processo reparatório bilateral, como se viu, não é indene de dificuldades. Além das dúvidas que cercam a determinação do regime jurídico de transição, avulta a questão da efetividade do modelo, haja vista a inexistência de instrumentos jurídicos capazes de impor ao poder legislativo a obrigatoriedade de produção normativa compatível com a Constituição, ainda mais quando essa positivação deve respeitar parâmetros estabelecidos pelo próprio poder judiciário.

Entretanto, a adequação funcional do modelo mostra-se suficientemente capaz de sustentar sua utilidade, ainda que surjam obstáculos processuais. Em primeiro lugar, porque não existem procedimentos perfeitos, mas sim procedimentos viáveis ou não a depender do caso concreto. Em segundo lugar, porque os dilemas específicos da reparação bilateral mostram-se superáveis quando se têm em vista algumas posturas adotáveis pelo poder judiciário.

Sobre o regime transitório, deve-se ter em vista que, apesar da aparente contradição em se manter a aplicabilidade de uma legislação reputada inconstitucional, não é outro o objetivo da modulação de efeitos. Seja quando esta técnica é utilizada no sentido de pronunciar uma sanção com efeitos ex nunc, seja quando ela é utilizada para se abrir prazo ao legislador, o que se tem é a preservação das relações jurídicas constituídas sob a vigência da legislação inconstitucional, o que se justifica não apenas 
por razões de segurança jurídica e interesse público, mas também pela ideia de que a jurisdição constitucional, especialmente quando exercida em controle abstrato, aproxima-se da atividade legislativa, em sentido negativo.

Ademais, não se deve olvidar que os efeitos temporais da sanção de nulidade não constituem solução imposta pela natureza, mas sim são criados pela razão humana, através da definição do legislador e da prática dos operadores do direito. Isso quer dizer que a eficácia ex tunc das decisões de inconstitucionalidade não são uma decorrência necessária destas, mas sim uma regra que visa atender a uma ideia estrita de rigidez constitucional, desenvolvida no âmbito do modelo norte-americano de controle. Assim, diferente de um reconhecimento de anomalias intrínsecas, cuja constatação pode ser feita por toda e qualquer pessoa, a declaração de inconstitucionalidade com efeitos ex tunc nada mais é senão uma sanção imposta pela autoridade competente (poder judiciário) que atinge eventos passados. Afinal, é a decisão judicial superveniente que determina esta consequência, razão pela qual a eficácia declaratória não passa de uma ficção jurídica para se atingir fatos jurídicos passados. A prova de que a eficácia ex tunc não é peremptória pode ser encontrada no próprio ambiente constitucional norteamericano, que hoje admite a possibilidade de se manter relações jurídicas constituídas sob a lei declarada inconstitucional ${ }^{301}$.

Noutro giro, é preciso avaliar que soluções em sentido diverso, como seria o caso de suspensão da eficácia da legislação inconstitucional pelo período ofertado ao legislador para reforma, ou mesmo a definição de um regime jurídico transitório para reger as situações durante o prazo estabelecido, poderia ensejar algo que deve ser rechaçado: medidas cautelares de caráter satisfativo (suspensão da aplicabilidade das normas inconstitucionais) ou mesmo medidas cautelares com efeitos aditivos. A primeira delas deve ser evitada porque corresponderia a uma decisão final de invalidade. Destarte, eventual suspensão deve se dar apenas com relação a processos com o mesmo objeto que estejam tramitando no Supremo Tribunal Federal ou nos

\footnotetext{
${ }^{301}$ Elival da Silva Ramos explica: "Nos sistemas de controle de matriz estadunidense, a atenuação das consequências drásticas da sanção de nulidade costuma ser alcançada por meio da preservação, excepcional, dos efeitos de algumas situações estabelecidas sob o amparo da legislação invalidada. Para tanto, na decisão de casos concretos, após haver, incidentalmente, declarado a inconstitucionalidade de lei ou dispositivo legal, recorre o magistrado à técnica argumentativa da ponderação entre os princípios e regras constitucionais que indicam para a implementação de todos os consectários da sanção de nulidade e os princípios, também de porte constitucional, que militam no sentido de se resguardar as situações fáticas constituídas sob o pressuposto falso da validade do direito impugnado". Cf. Ativismo judicial: parâmetros dogmáticos, p. 201.
} 
demais órgãos e tribunais inferiores, mas não com relação aos regimes jurídicos em si. Já a segunda possibilidade deve ser afastada porque efeitos aditivos não podem ser determinados em sede cautelar, que se volta não para a resolução do mérito, mas sim para o resguardo da efetividade do processo.

Por fim, deve ser enfrentado o dilema mais importante, atinente ao cumprimento ou não da determinação feita ao poder legislativo. Mais precisamente, deve ser analisada a hipótese segunda, em que o legislador não atende, ou atende parcialmente, ao apelo do poder judiciário e deixa o prazo transcorrer sem a efetivação de medida hábil a contornar a inconstitucionalidade identificada. Mesmo porque, caso o legislador cumpra seu papel de modo integral, não haverá um dilema, mas sim um satisfatório êxito do modelo bilateral desenhado.

Pois bem. O que fazer diante do descumprimento, total ou parcial, do legislador? De um lado, incide o limite funcional que impede ao poder judiciário imiscuir-se na função legislativa e promulgar, ele mesmo, legislação compatível com o direito de igualdade. De outro lado, sobressai o vazio normativo como um perigo a ser evitado pelo poder judiciário, o chamado horror vacui, já elucidado. "Entre a cruz e a espada" seria a expressão coloquial a ser utilizada para descrever a situação.

A resposta mais coerente, com o sistema brasileiro de jurisdição constitucional e com o trabalho até aqui desenvolvido, é a sanção de nulidade completa da relação internormativa inconstitucional (sentença de desconstrução). Em primeiro lugar, porque é o instrumento mais eficaz à disposição do poder judiciário. Em segundo lugar, porque é inerente à sua função ${ }^{302}$.

Nesse sentido, embora o vazio normativo seja um fator preponderante para a construção de um modelo bilateral de restauração da igualdade no ordenamento, ele não constitui, propriamente, uma irregularidade, por uma simples razão: ele é consequência ínsita ao controle de constitucionalidade dos atos legislativos. Portanto, embora diversos fatores recomendem o chamamento do legislador para atuar em conjunto com o judiciário na reparação da inconstitucionalidade, nenhum deles indica que, em caso de descumprimento, o judiciário deve tomar as providências não tomadas pelo legislador.

${ }^{302}$ É o que defende Rui Medeiro: "Afigura-se claro que a sanção em princípio aplicável às leis que atribuem direitos em violação do princípio da igualdade passa, na ordem jurídica portuguesa, pela decisão de invalidade total, ainda que com limitação de efeitos". Cf. A decisão de inconstitucionalidade, pp. $522-523$. 
Nestas circunstâncias, o que se verifica é o insucesso do modelo, razão pela qual a sanção de nulidade se torna inevitável.

Além disso, não se deve descartar o fato de que a sanção de invalidade total naturalmente ensejaria maior força persuasória em face do poder legislativo. Isto é, a possibilidade de anulação de toda a relação questionada geraria, ao menos em tese, maior pressão sobre o legislador ${ }^{303}$. Considerando a possibilidade de recalcitrância, o órgão judicial poderia, já no ato de modulação de efeitos, determinar que o descumprimento do apelo ensejará a declaração da invalidade completa da legislação questionada.

Antes de concluir, vale consignar que, caso o vazio normativo fosse algo a ser evitado a qualquer custo, a própria existência do controle de constitucionalidade deveria ser colocada em xeque. No entanto, este não é o propósito desta dissertação, que trabalha com o pressuposto de que a jurisdição constitucional e a sanção de nulidade dos atos inconstitucionais são necessárias para o respeito da supremacia e rigidez constitucionais. O que se discute é a melhor forma de se exercer essa atividade quando se tem como parâmetro o direito de igualdade.

Em conclusão, é imperioso advertir que tanto num legislativo que não legisla, quanto num judiciário que assim o faz, o que existe é disfunção. E uma disfunção não corrige outra, mas sim cria mais uma, como ensina a lógica. Por isso, o chamado diálogo institucional entre os poderes não deve acarretar na confusão e na usurpação de poderes, sob pena de o visado diálogo dar lugar a uma verdadeira guerrilha institucional, onde já não se saberá quem responde pelo quê. Se o judiciário passar a responder pela ausência de leis e o legislativo pela manutenção de inconstitucionalidades (como de fato ocorreria se o judiciário legislasse ou se a ausência de reforma legislativa não culminasse na sanção de nulidade total), haverá uma completa inversão de papeis e funções no Estado brasileiro, o que deixaria o cidadão sem um dos principais mecanismos de limitação do poder, qual seja, a sua repartição de acordo com a função preponderantemente exercida.

\footnotetext{
303 Nessa direção caminha Rui Medeiros: “A decisão de inconstitucionalidade total, ainda que acompanhada de limitação de efeitos, tempo por outro lado a vantagem de não diminuir a pressão sobre o legislador, forçando-o a aprovar rapidamente uma nova regulamentação não discriminatória". Cf. A decisão de inconstitucionalidade, p. 523.
} 


\section{Conclusão}

O direito de igualdade é dotado de propriedades normativas peculiares. A primeira a ser ressaltada diz respeito à sua estrutura normativa, que é complexa e envolve três elementos básicos: sujeitos, critérios e finalidades. Noutro giro, a igualdade configura uma norma de natureza formal (ou então secundária, estruturante), pois não tem o condão de criar normas de conduta, mas sim é voltada para a regulação da própria criação e aplicação do Direito.

A igualdade aceita diversas dimensões, sendo que, em geral, elas apresentam-se de modo contraposto. Assim, à igualdade fática se contrapõe a igualdade normativa, enquanto que à igualdade formal se contrapõe a chamada igualdade material. Por fim, também a igualdade proporcional e a igualdade paritária configuram dimensões opostas da igualdade. No entanto, apesar das diferenças de perspectiva de cada uma dessas dimensões, é preciso reconhecer que o direito de igualdade é compatível com todas elas. Assim, examinar a igualdade não exige uma "escolha" entre uma delas. Na realidade, o grande desafio é compreender e definir o modo como essas dimensões interagem entre si e refletem na metódica de proteção judicial da igualdade.

Para guiar o trabalho de aplicação da igualdade, foi delineado um conceito desta, que pode ser resumido como a exigência: (i) de coerência lógica na interação de seus elementos estruturais, quais sejam, sujeitos, critério e finalidade, (ii) de compreensão da ideia de que todos nascem iguais em direitos, o que impede discriminações com fundamento na suposta superioridade ou inferioridade nata de alguns, disso decorrendo a ideia de não discriminação, e (iii) de proporção na atribuição de direitos e obrigações, cabendo porções iguais para sujeitos iguais e porções desiguais para sujeitos desiguais.

No que tange à tutela judicial da igualdade, concluiu-se que a relação de inconstitucionalidade típica do controle da igualdade é composta de três, e não dois, regimes. Isto é, ao servir de parâmetro para a jurisdição constitucional, a igualdade enseja uma análise comparativa de dois regimes jurídicos infraconstitucionais. Por essa razão, ela pode ser considerada uma relação internormativa tripolar (dois regimes infraconstitucionais e uma norma constitucional de igualdade). 
A inconstitucionalidade por violação à igualdade pode ocorrer seja por conta de ações legislativas, seja por omissões. Do mesmo modo, a inconstitucionalidade pode ser total, ou seja, abranger ambos os regimes jurídicos comparados à luz da igualdade, ou então parcial, referindo-se a apenas um dos regimes. Por último, a inconstitucionalidade pode ser explícita ou implícita, sendo aquela correspondente às violações expressas no ordenamento e estas relativas às inconstitucionalidades tácitas que exigem interpretação sistemática e/ou histórica para serem identificadas.

Sobre a decisão de inconstitucionalidade, definiu-se que a igualdade enseja uma tipologia variada, que abrange sentenças de simples declaração de inconstitucionalidade cumulada com a sanção de nulidade ex tunc, sentenças manipulativas do conteúdo das normas, bem assim sentenças que modulam seus efeitos temporais.

A reparação do estado de igualdade pode se dar de várias formas. Ela pode resultar de uma diferenciação entre regimes jurídicos que eram equiparados (caso se aplique a igualdade proporcional entre desiguais), de uma equiparação entre regimes originalmente diferenciados (por aplicação da igualdade paritária, ou então da igualdade proporcional entre iguais), ou mesmo de uma desconstrução de ambos os regimes colocados em comparação.

Por se tratar de uma norma peculiar, que atua como metanorma estruturante do ordenamento, a igualdade é sensível à questão da separação de poderes. Isso porque ela pode ser utilizada para fundamentar remodelações de regimes jurídicos nas mais diversas formas. Ademais, por envolver correlação de critérios e finalidades, bem como a análise de circunstâncias fáticas variáveis no tempo, a igualdade permite uma liberdade de conformação do legislador que deve ser respeitada pelo poder judiciário. Por conta disso, foram desenvolvidos dois modelos de reparação, um que enseja a atuação direta e unilateral do poder judiciário, e outra que requer a atuação dos poderes políticos, em especial o poder legislativo.

Após a análise das características essenciais e da legitimidade do modelo unilateral, conclui-se que ele é admissível quando preenchidos os seguintes requisitos: existência de uma relação de igualdade bem delineada a nível constitucional, suficiência da sanção de nulidade para se restabelecer o estado de igualdade, e, por fim, o maior respeito dos regimes gerais em face dos especiais. 
Por sua vez, o modelo bilateral tem requisitos simetricamente opostos aos requisitos ensejadores do modelo unilateral. Em primeiro lugar, não deve haver uma relação de igualdade predeterminada na Constituição, o que gera maior liberdade de conformação do legislativo, a ser respeitada. Noutro giro, a eventual insuficiência da sanção de nulidade deve acarretar na instauração do modelo bilateral, e não a prolação de sentenças manipulativas do conteúdo dos regimes jurídicos. Outro requisito é o da insegurança jurídica eventualmente provocada pelo vazio jurídico resultante da nulidade típica do modelo unilateral (horror vacui). Por fim, a possibilidade da reparação unilateral provocar desequilíbrios orçamentários deve ser levado em conta na decisão pelo modelo bilateral.

Quanto aos aspectos processuais, concluiu-se que o controle concreto enfrenta dificuldades relativas à delimitação do objeto e à restrição dos efeitos apenas às partes no processo. Este segundo obstáculo pode ser atenuado pelas técnicas de uniformização de jurisprudência. Já o controle abstrato enfrenta dilemas relativos ao instrumento a ser utilizado e à vinculação de suas decisões, seja com relação aos demais poderes, seja com referência aos demais órgãos do poder judiciário.

Por fim, delineou-se um modelo reparatório dialógico que reclama a conjugação da função jurisdicional e legislativa no processo de restauração do estado de igualdade. Concluiu-se que a modulação de efeitos para o futuro permite ao Supremo Tribunal Federal remeter aos poderes políticos (legislativo e executivo) a tarefa de reformar regimes jurídicos declarados inconstitucionais por violação à igualdade. A razão disso é que tal procedimento respeita tanto as normas de igualdade, quanto as normas que estabelecem a divisão de funções entre os poderes. 


\section{BibLIOGRAFIA}

Alexy, Robert. Teoria dos direitos fundamentais. São Paulo: Malheiros, 2008.

ANDRADE, JosÉ VIEIRA DE. Os direitos fundamentais na Constituição portuguesa de 1976. $3^{\mathrm{a}}$ ed. Lisboa: Almedina, 2004.

ARISTÓTELES. Ética a Nicômaco. 3ª ed. Bauru: Edipro, 2009.

. A política. São Paulo: Martins Fontes, 2006.

Ávila, Humberto. Teoria da igualdade tributária. $2^{\mathrm{a}}$ ed. São Paulo: Malheiros, 2009.

Bandeira de Mello, Celso Antônio. O conteúdo jurídico do princípio da igualdade. $3^{\mathrm{a}}$ ed. São Paulo: Malheiros Editores, 2010.

BARboSA, Rui. Oração aos moços. São Paulo: Editora Martin Claret, 2003.

. Atos inconstitucionais. $3^{\mathrm{a}}$ ed. Campinas: Russel Editores, 2010.

BARROSO, Luís RoBERTO. O controle de constitucionalidade no direito brasileiro. $2^{\mathrm{a}}$ ed. São Paulo: Saraiva, 2006.

Beilfuss, Markus GonZÁles. Tribunal constitucional y reparación de la discriminación normativa. Madri: Centro de Estudios Políticos y Constitucionales, 2000 .

Bitencourt, Lúcio C. A. O contrôle jurisdicional da constitucionalidade das leis. Rio de Janeiro: Forense, 1968.

Bobbio, Norberto. Teoria geral do direito. São Paulo: Martins Fontes, 2007.

CAnotilho, José JOAQuim GOMES. Constituição dirigente e vinculação do legislador. $2^{\mathrm{a}}$ ed. Coimbra: Coimbra Editora. 2001.

. Direito constitucional e teoria da Constituição. $7^{\mathrm{a}}$ ed. Lisboa:

Almedina, 2003.

CARneiro, Athos Gusmão. Jurisdição e competência. 14 ${ }^{\mathrm{a}}$ ed. São Paulo: Editora Saraiva, 2005. 
Cavalcanti, Francisco de Queiroz Bezerra. O Supremo Tribunal Federal e a inconstitucionalidade por omissão parcial. Revista Esmafe: Escola de Magistratura Federal da $5^{\text {a }}$ Região, Recife, n. 2, p. 19-26, maio, 2001. Disponível em: ww4.jfpe.jus.br:8080/biblioteca/juizes/queiroz_esmafe02_p19-26.pdf. Acesso em: 26. 10.2012 .

Celotto, Alfonso. "Il controlo di eguaglianza sulle leggi in Italia". In: Manuel Carrasco Durán, Francisco Javier Pérez Royo, Joaquín Urías Martínez, Manuel José Terol Becerra (coord.), Derecho constitucional para el siglo XXI : actas del VIII Congreso Iberoamericano de Derecho Constitucional, Vol. 1, 2006, ISBN 84-9767692-0, páginas 913-930. $\quad$ Disponível em http://congreso.us.es/cidc/Ponencias/igualdad/CelottoEguaglianza.pdf. Acesso em 27.10.2012.

La Corte Costituzionale. Bologna: Il Mulino, 2004.

Clève, Clèmerson Merlin. A fiscalização abstrata da constitucionalidade no direito brasileiro. $2^{\mathrm{a}}$ ed. São Paulo: Editora Revista dos Tribunais, 2000.

De LAURENTIIS, LuCAS CATIB. Interpretação conforme a Constituição: conceito, técnicas e efeitos. São Paulo: Malheiros Editores, 2012.

DíEZ-PiCAZO, Luis MARIA. Sistema de derechos fundamentales. $2^{\mathrm{a}}$ ed. Navarra: Editorial Aranzadi, 2005.

DwOrkin, Ronald. A virtude soberana: a teoria e a prática da igualdade. São Paulo: Martins Fontes, 2005.

Ely, John Hart. Democracy and distrust: a theory of judicial review. Fourteenth printing. Cambridge: Harvard University Press, 2002.

ENGISCH, KARL. Introdução ao pensamento jurídico. $10^{\mathrm{a}}$ ed. Lisboa: Fundação Galouste Gulbenkian, 2008.

Faria, Anacleto De Oliveira. Do princípio da igualdade jurídica. São Paulo: Ed. Revista dos Tribunais, 1973.

FAVOREU, LOUIS. As cortes constitucionais. São Paulo: Landy Editora, 2004. 
Ferrari, Regina Maria Nery. Direito constitucional. São Paulo: Editora RT, 2011.

Ferraz JR. Tercio SAMPAiO. Introdução ao estudo do direito: técnica, decisão, dominação. $4^{\text {a }}$ ed. São Paulo: Atlas, 2003.

Teoria da norma jurídica. $4^{\mathrm{a}}$ ed. Rio de Janeiro: Editora Forense, 2006.

Ferreira Filho, Manoel Gonçalves. Estado de Direito e Constituição. $4^{a}$ ed. São Paulo: Editora Saraiva, 2007.

. Princípios fundamentais do direito constitucional. São Paulo: Editora Saraiva, 2009.

FleisCHACKER, SAMUEL. Uma breve história da justiça distributiva. São Paulo: Martins Fontes, 2006.

Garcia, Maria GlóRIA F. P. D. Estudos sobre o princípio da igualdade. Coimbra: Edições Almedina, 2005.

GÓMEZ, MARÍA ISABEL GARRIDO. La igualdad en el contenido y em la aplicación de la ley. Madri: Dykinson, 2009.

GuASTINI, RICARDO. Das fontes às normas. São Paulo: Quartier Latin, 2005.

GRAU, EROS. Ensaio e discurso sobre a interpretação/aplicação do direito, $3^{\text {a }}$ ed. São Paulo: Malheiros Editores, 2005.

HABERMAS, JÜRGEN. Direito e democracia: entre facticidade e validade. $2^{\mathrm{a}}$ ed. Trad. Flávio Beno Siebeneichler. Rio de Janeiro: Tempo Brasileiro, 2003.

Hamilton, AleXander; Madison, James; Jay, John. O Federalista. $3^{\text {a }}$ ed. Campinas: Russel Editores, 2009.

KELSEN, HANS. Jurisdição constitucional. $2^{\text {a }}$ ed. São Paulo: Martins Fontes, 2007.

LAREnZ, KARL. Metodologia da ciência do direito, $6^{a}$ ed. Lisboa: Fundação Calouste Gulbenkian, 2012.

Leal, Roger Stiefelmann. O efeito vinculante na jurisdição constitucional. São Paulo: Saraiva, 2006. 
"A incorporação das súmulas vinculantes à jurisdição constitucional brasileira: alcance e efetividade em face do regime legal da repercussão geral e da proposta de revisão jurisprudencial sobre a interpretação do art. 52, X, da Constituição". In: Revista de Direito Administrativo, vol. 261. Rio de Janeiro: Editora Forum, 2012.

. "A convergência dos sistemas de controle de constitucionalidade: aspectos processuais e institucionais". In: Revista de direito constitucional e internacional, ano 14, n. 57, outubro-dezembro de 2006. São Paulo: Editora Revista dos Tribunais, 2006.

- "O exercício da jurisdição constitucional pelo poder judiciário. In:

Almeida, Fernando Dias Menezes; Amaral Júnior, José Levi Mello do; Horbach, Carlos Bastide (coord.); Direito Constitucional, Estado de Direito e Democracia. São Paulo: Quartier Latin, 2011.

LuÑo, ANTÔNIO ENRIQUe PÉREZ. Dimensiones de la igualdad. 2aed. Madri: Dykinson, 2007.

MAncuso, RODOLFO DE CAMARGO. Divergência jurisprudencial e súmula vinculante. $4^{\mathrm{a}}$ ed. São Paulo: Editora Revista dos Tribunais, 2010.

MedeIRos, Rui. A decisão de inconstitucionalidade: os autores, o conteúdo e os efeitos da decisão de inconstitucionalidade da lei. Lisboa: Universidade Católica Editora, 1999.

Mendes, Gilmar Ferreira; Coelho, Inocêncio Mártires; Branco, Paulo Gustavo Gonet, Curso de direito constitucional, 4ª ed. São Paulo: Saraiva, 2009.

Mendes, Gilmar Ferreira. Jurisdição Constitucional: o controle abstrato de normas no Brasil e na Alemanha. 5a ed. São Paulo: Saraiva, 2005.

Direitos fundamentais e controle de constitucionalidade: estudos de direito constitucional. $3^{\text {a }}$ ed. São Paulo: Saraiva, 2004.

Miranda, Jorge. Contributo para uma teoria da inconstitucionalidade. $1^{\text {a }}$ ed. Coimbra: Coimbra Editora, 2007.

Manual de direito constitucional, tomo IV: direitos fundamentais. $5^{\text {a }}$ ed. Coimbra: Coimbra Editora, 2012. 
Manual de direito constitucional, tomo VI: inconstitucionalidade e garantia da Constituição. $3^{\text {a }}$ ed. Coimbra: Coimbra Editora, 2008.

MonTElOBO, SOFIA. "A tutela das omissões relativas geradas pela violação do princípio da igualdade através do controlo de constitucionalidade por acção". In: As sentenças intermédias da justiça constitucional. Lisboa: AAFDL, 2009.

Morais, CARlos BlanCO DE. Justiça constitucional, tomo I: garantia da Constituição e controlo da constitucionalidade. $2^{\text {a }}$ ed. Coimbra: Coimbra Editora, 2006.

. Justiça constitucional, tomo II: o contencioso constitucional português entre o modelo misto e a tentação do sistema de reenvio. Coimbra: Coimbra Editora, 2005.

As sentenças com efeitos aditivos. In: Carlos Blanco de Morais (coord.), “As sentenças intermédias da justiça constitucional”, Lisboa: AAFDL, 2009.

MÜLLER, FRIEDRICH. Metodologia do direito constitucional. $4^{\text {a }}$ ed. São Paulo: Editora Revista dos Tribunais, 2010.

. Teoria estruturante do direito, $2^{\mathrm{a}}$ ed. São Paulo: Editora Revista dos Tribunais, 2009.

Neves, MARCELo. Teoria da inconstitucionalidade das leis. São Paulo: Saraiva, 1988.

Novais, JORGE ReIS. Os princípios constitucionais estruturantes da República Portuguesa. Coimbra: Coimbra Editora, 2004.

Piovesan, Flávia. Proteção judicial contra omissões legislativas. $2^{\mathrm{a}}$ ed. São Paulo: Editora Revista dos Tribunais, 2003.

PaIVA, Paulo. A fungibilidade entre ADI e ADO e as técnicas de decisão que resolvem omissões legislativas inconstitucionais parciais. In: Observatório da Jurisdição Constitucional, Ano 3, 2009/2010. Disponível em http://www.portaldeperiodicos.idp.edu.br/index.php/observatorio/article/view/387/265. Acesso em 26.10.2012. 
Ramos, Elival da Silva. Controle de constitucionalidade no Brasil: perspectivas de evolução. São Paulo: Saraiva, 2010.

. Ativismo judicial: parâmetros dogmáticos. São Paulo: Saraiva, 2010.

. A inconstitucionalidade das leis. São Paulo: Saraiva, 1994.

Rocha, CARMen LÚCIA Antunes. O princípio constitucional da igualdade. Belo Horizonte: Editora Lê, 1990.

Rodriguez, Jose Julio Fernandez. La inconstitucionalidade por omisión. Teoria general. Derecho comparado. El caso español. Madri: Editorial civitas, 1998.

SÁ, FÁtIMA. "Omissões inconstitucionais e sentenças aditivas". In: As sentenças intermédias da justiça constitucional. Lisboa: AAFDL, 2009.

SAndel, Michael J. Justiça: o que é fazer a coisa certa. $6^{a}$ ed. Rio de Janeiro: Civilização Brasileira, 2012.

Sarlet, Ingo Wolfgang. A eficácia dos direitos fundamentais. $8^{\mathrm{a}}$ ed. Porto Alegre: Livraria do Advogado Editora, 2007.

SARMENTO, DANIEL. Direitos fundamentais e relações privadas. $2^{\mathrm{a}}$ ed. Rio de Janeiro: Lumen Juris Editora, 2006.

SEGADO, FRANCISCO FERNÁNDEZ. El control de constitucionalidade de las omisiones legislativas; algunas cuestiones dogmáticas. In: Estudios Constitucionales, Año $7, \mathrm{n}^{\circ}$ 2, 2009, pp. 13-69. Disponível em http://www.scielo.cl/scielo.php?pid=S071852002009000200002\&script=sci_arttext. Acesso em 26.10.2012.

SILVA, JosÉ AfONSO DA. Aplicabilidade das normas constitucionais. $7^{\text {a }}$ ed. São Paulo: Malheiros Editores, 2007.

SILVA, JoRge PEREIRA DA. Dever de legislar e proteção jurisdicional contra omissões legislativas: contributo para uma teoria da inconstitucionalidade por omissão. Lisboa: Universidade Católica Editora, 2003.

Tucci, José Rogério CruZ e. Precedente judicial como fonte do direito. São Paulo: Editora Revista dos Tribunais, 2004. 
Vega, Augusto Martín de La. La sentencia constitucional en Italia. Madrid: Centro de Estudios Políticos y Constitucionales, 2003.

Veloso, Zeno. Controle jurisdiccional de constitucionalidade. $2^{\mathrm{a}}$ ed. Belo Horizonte: Del Rey, 2000

WESTERn, PETER. Speaking of equality: an analysis of the rhetorical force of 'equality' in moral and legal discourse. Princeton: Princeton University Press, 1990.

XAVIER, TACIANA. “A tutela das omissões relativas (geradas pela violação do princípio da igualdade) através do controle de constitucionalidade por ação, no sistema jurídico brasileiro". In: As sentenças intermédias da justiça constitucional. Lisboa: AAFDL, 2009.

ZAGREBELSKY, GuSTAVO. La giustizia costituzionale. Bologna: Il Mulino, 1988.

ZAVASCKI, TEORI AlBINO. Eficácia das sentenças na jurisdição constitucional. $2^{\mathrm{a}}$ ed. São Paulo: Editora Revista dos Tribunais, 2012. 